UNIVERSIDADE DE SÃO PAULO

INSTITUTO DE PSICOLOGIA

\title{
ASTROLOGIA E PERSONALIDADE: \\ O EFEITO DO CONHECIMENTO DAS \\ CARACTERÍSTICAS DO SIGNO SOLAR \\ EM VARIÁVEIS MEDIDAS PELO 16 PF
}

PAULO ROBERTO GRANGEIRO RODRIGUES

SÃo PAULO

2004 


\title{
ASTROLOGIA E PERSONALIDADE: \\ O EFEITO DO CONHECIMENTO DAS
}

\section{CARACTERÍSTICAS DO SIGNO SOLAR EM}

\author{
VARIÁVEIS MEDIDAS PELO 16 PF
}

Tese apresentada ao Instituto de Psicologia da Universidade de São Paulo, como parte dos requisitos para obtenção do grau de Doutor em Psicologia

Área de concentração: Psicologia Social

Orientadora: Dra. Anna Mathilde Pacheco e Chaves Nagelschmidt

SÃo PAULO

2004 
Ficha Catalográfica preparada pelo Serviço de Biblioteca e Documentação do Instituto de Psicologia da USP

Rodrigues, P. R. G.

Astrologia e personalidade: o efeito do conhecimento das características do signo solar em variáveis medidas pelo 16 PF./ Paulo Roberto Grangeiro Rodrigues. - São Paulo: s.n., 2004. - 160p.

Tese (doutorado) - Instituto de Psicologia da Universidade de São Paulo. Departamento de Psicologia Social e do Trabalho.

Orientadora: Anna Mathilde Pacheco e Chaves Nagelschmidt.

1. Astrologia 2. Atribuição de causalidade 3. Personalidade 4. Questionário de dezesseis fatores de personalidade I. Título. 


\section{ASTROLOGIA E PERSONALIDADE: O EFEITO DO CONHECIMENTO DAS CARACTERÍSTICAS DO SIGNO SOLAR EM VARIÁVEIS MEDIDAS PELO 16 PF}

PAULO ROBERTO GRANGEIRO RODRIGUES

BANCA EXAMINADORA

(Nome e Assinatura)

(Nome e Assinatura)

(Nome e Assinatura)

(Nome e Assinatura)

(Nome e Assinatura)

Tese defendida e aprovada em 


\section{AGRADECIMENTOS}

Gostaria de ser mais efusivo, mas minha tendência é de ser conciso. Meu signo, Escorpião, prevê uma introversão e uma concentração que no meu caso são facilmente constatáveis. Mas tenho muito a agradecer, de muita gente amiga e companheira. Não se faz ciência sozinho, diz minha orientadora, e o percebi muito bem com esta Tese. Houve muitos colaboradores: Mais uma vez a orientadora conduziu com firmeza meu pensamento e minha produção. Ficam mais lições, sobre honestidade científica, clareza mental e atualização de conhecimentos. Mais ainda, sua Mandala de Palavras me iluminou numa fase crucial da análise dos dados. Minha mãe Antônia continuou com seu apoio, seu incentivo e suas bênçãos, conduzindo meus sentimentos e minha autoconfiança de modo sutil. Meus filhos Ísis e Tiago, cada um a seu modo participando desta empreitada longa e difícil, compreendendo minhas ausências. Minha companheira Ana, que deu tanto apoio e suportou muitas vezes minhas angústias e ansiedades. Os amigos Américo Rufino (meu pai espiritual), Gilberto Sandonato (cientista do INPE, de longas conversas sobre Similaridade e interfaces entre Física e Psicologia); José Luis da Silva, do CTA, sugerindo e apoiando. O casal de amigos pesquisadores Rose Mary e Marcelo Lopes. Os colegas professores Elias Boainain, da UNITAU; Walter Dias, Danielle Corga, Antônio Carlos Peixoto, Patrícia Accacio, Orlete de Lima, da UNIP, que ajudaram tanto por diálogos esclarecedores quanto por colaborarem gentilmente na coleta dos dados. Os alunos, que desde 1999 têm colaborado para meu crescimento profissional, especialmente aqueles alunos cujos resultados de testes foram usados nesta pesquisa. A amiga Dra. Augusta Soares Correa, na tradução do resumo para o francês. A todos estes e mais aqueles que colaboraram de alguma forma para a realização prática do Doutorado e a publicação dessa Tese, minha gratidão eterna, e que a felicidade da realização possa ser compartilhada. 


\section{SUMÁRIO}

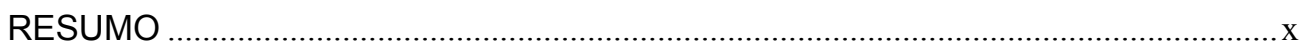

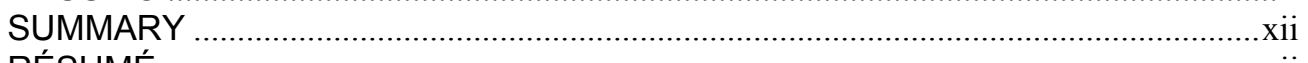

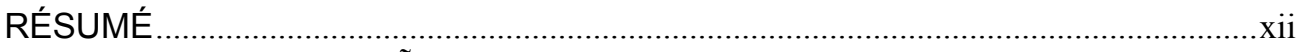

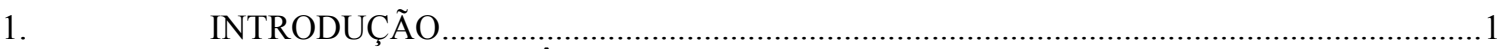

1.1. ASTROLOGIA E SUA IMPORTÂNCIA NA CULTURA OCIDENTAL ................................................

1.2. “A SOMATÓRIA DE TODO O CONHECIMENTO PSICOLÓGICO DA ANTIGUIDADE"............16

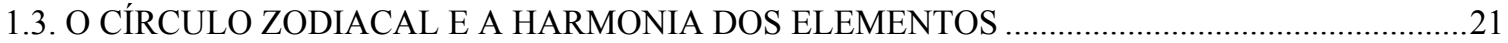

1.4. TESTANDO OS SIGNOS, OS ELEMENTOS E AS DIMENSÕES DE PERSONALIDADE ..............34

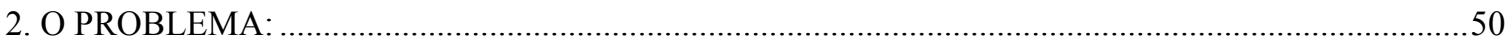

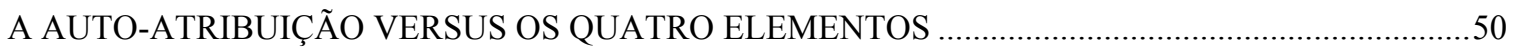

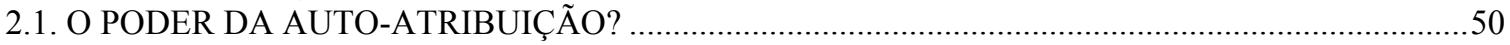

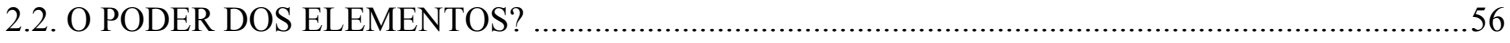

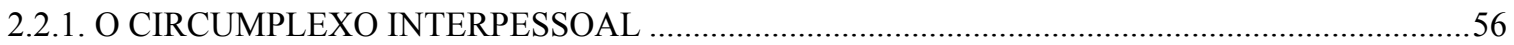

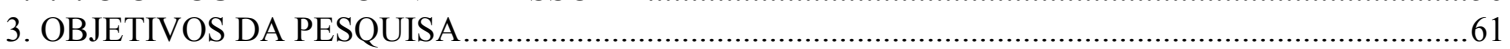

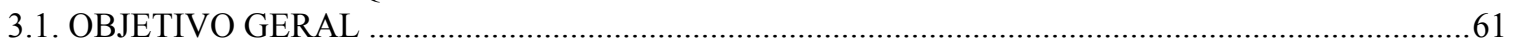

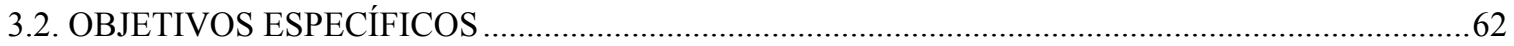

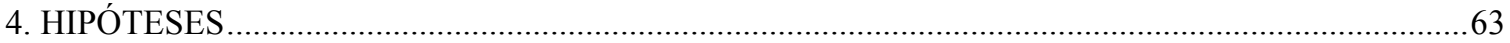

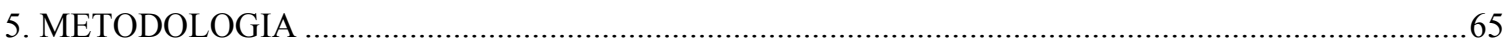

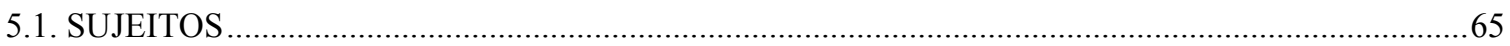

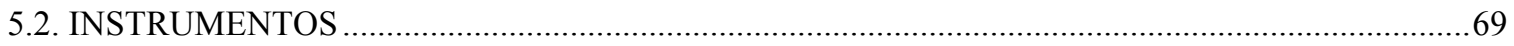

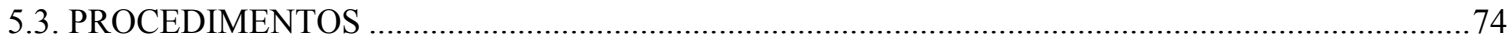

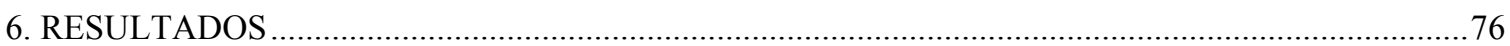

6.1. AMOSTRA DIVIDIDA ENTRE NÃO CONHECEDORES E CONHECEDORES DA ASTROLOGIA

6.1.1. EXTROVERSÃO NO GRUPO DE NÃO CONHECEDORES DA ASTROLOGIA ...........................77

6.1.2. EXTROVERSÃO NO GRUPO DE CONHECEDORES DA ASTROLOGIA ……............................78

6.1.3. EXPANSIVIDADE PARA GRUPO DE NÃO CONHECEDORES................................................... 81

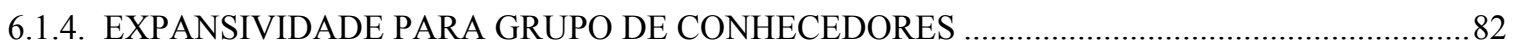

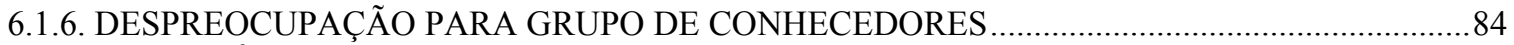

6.1.7. INTELIGÊNCIA NO GRUPO DE NÃO CONHECEDORES DA ASTROLOGIA...............................

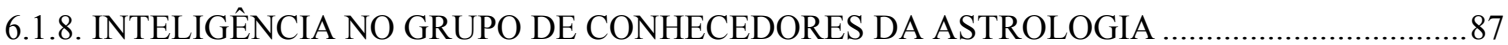

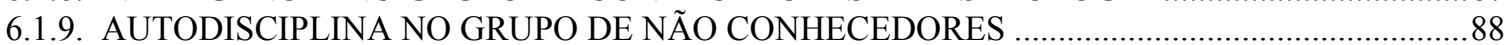

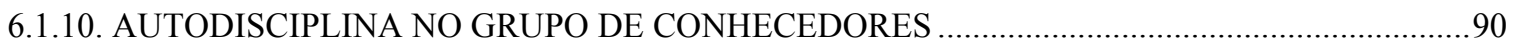

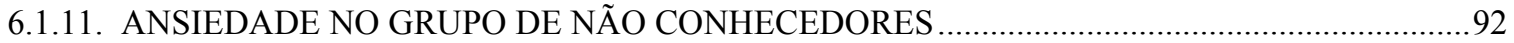

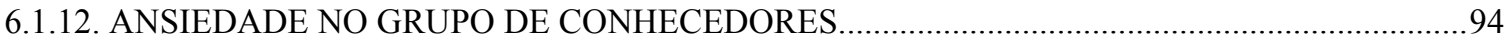

6.1.13. ESTABILIDADE EMOCIONAL NO GRUPO DE NÃO CONHECEDORES …………...................96

6.1.14. ESTABILIDADE EMOCIONAL NO GRUPO DE CONHECEDORES..........................................97

6.1.15. DESCONFIANÇA NO GRUPO DE NÃO CONHECEDORES ..............................................98

6.1.16. DESCONFIANÇA NO GRUPO DE CONHECEDORES............................................................99

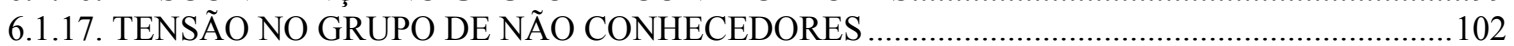

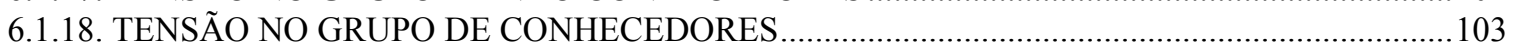

6.2. O GRUPO DE CONHECEDORES DA ASTROLOGIA E O EFEITO DA SUGESTÃO …...............107

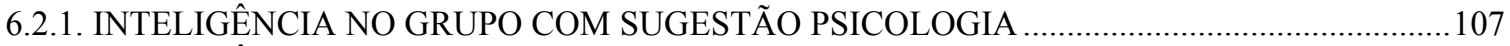

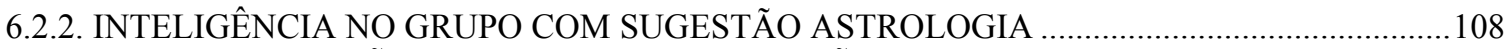

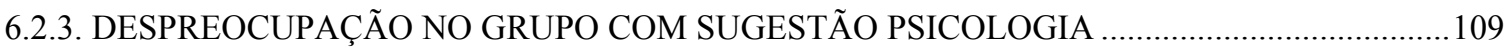

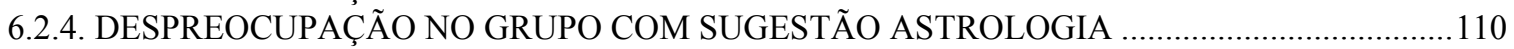

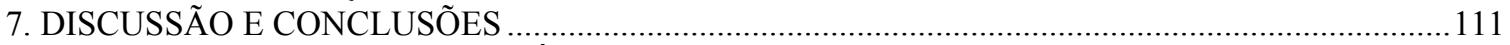

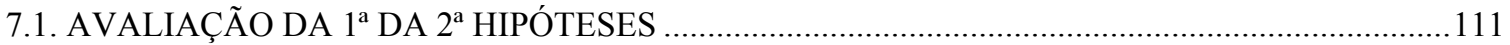

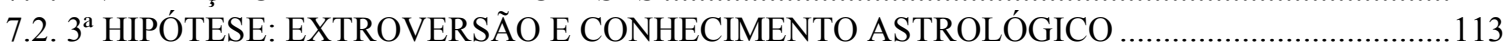

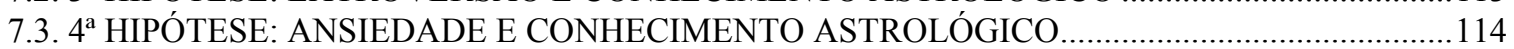

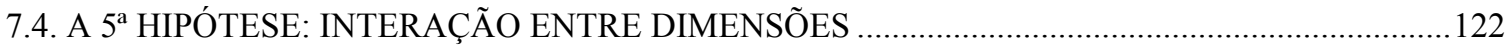

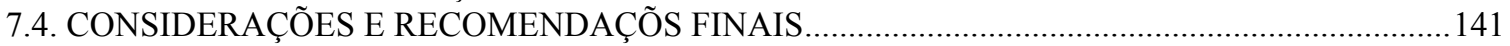

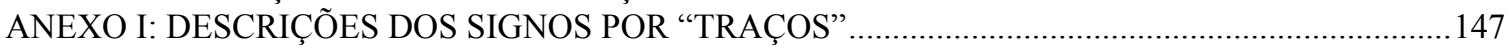

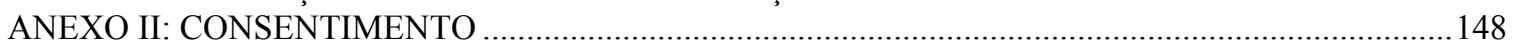

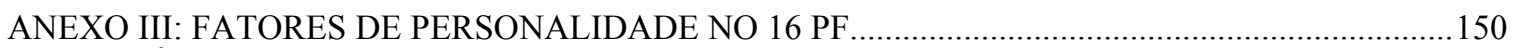

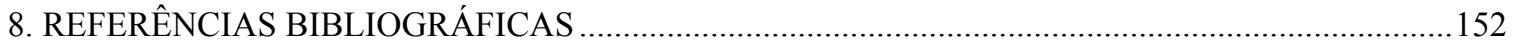




\section{LISTA DE TABELAS}

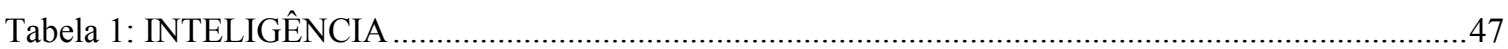

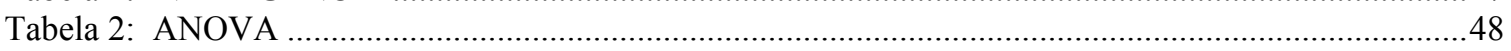

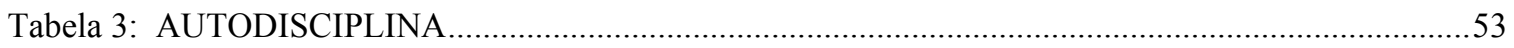

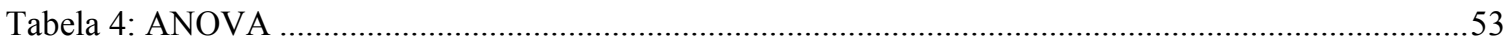

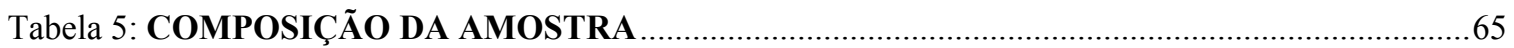

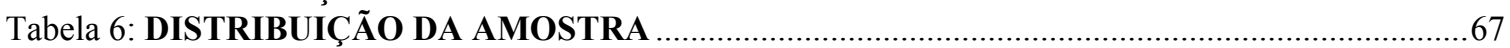

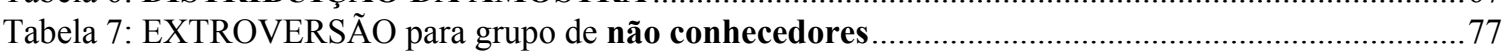

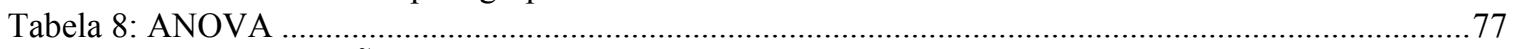

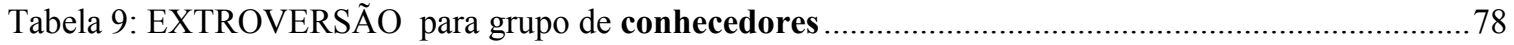

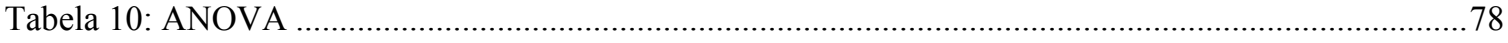

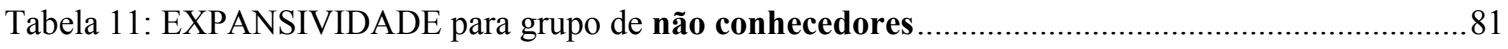

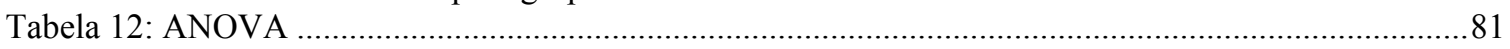

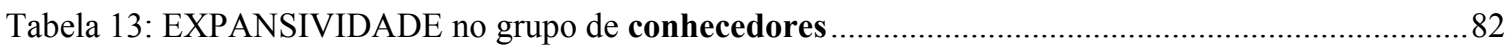

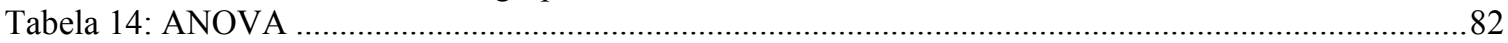

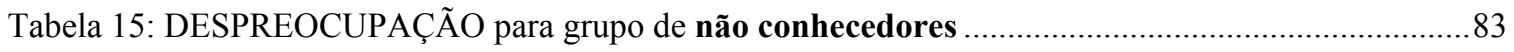

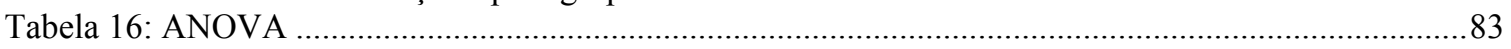

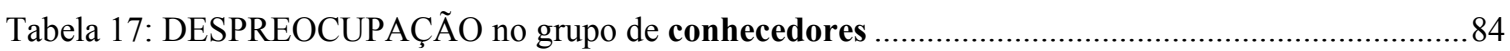

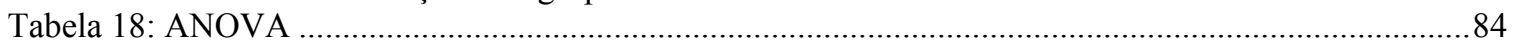

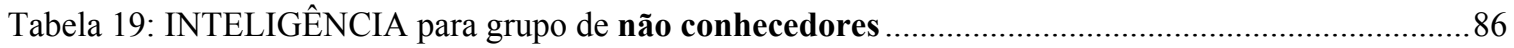

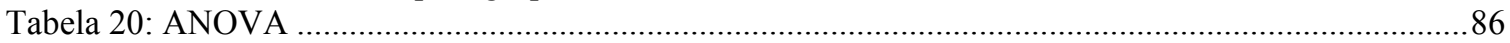

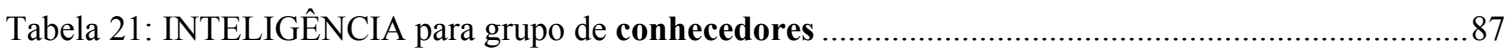

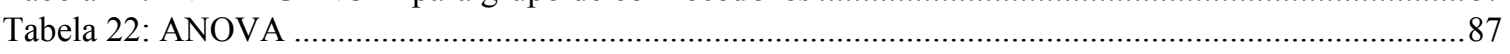

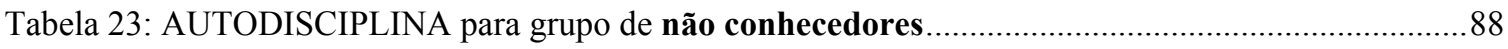

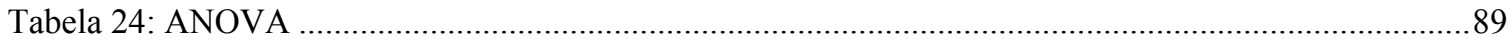

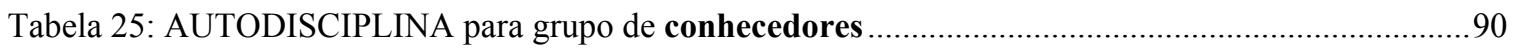

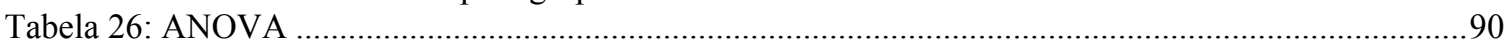

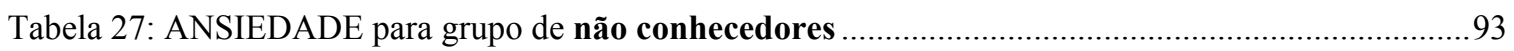

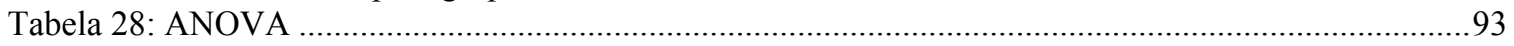

Tabela 29: ANSIEDADE para grupo de conhecedores ………………………………….......................95

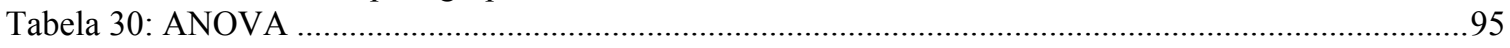

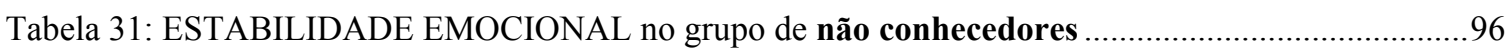

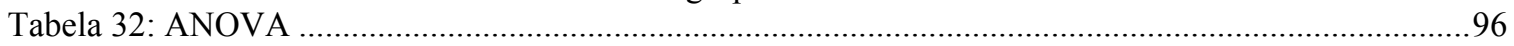

Tabela 33: ESTABILIDADE EMOCIONAL para grupo de conhecedores ……………….........................97

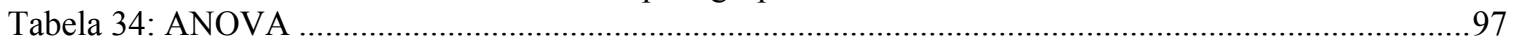

Tabela 35: DESCONFIANÇA para grupo de não conhecedores ............................................................98

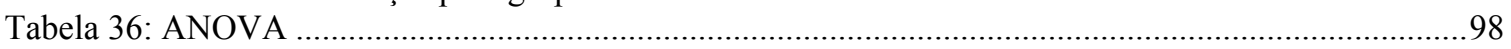

Tabela 37: DESCONFIANÇA no grupo de conhecedores ......................................................................99

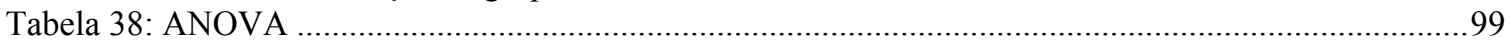

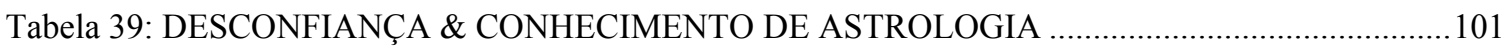

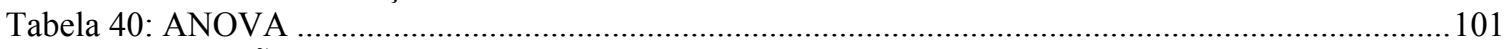

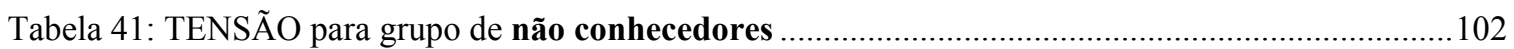

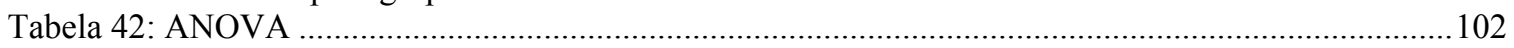

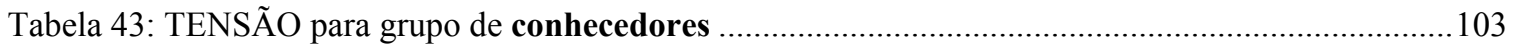

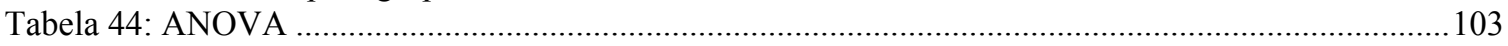

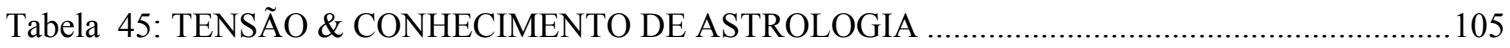

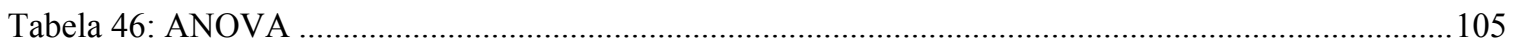

Tabela 47: DESPREOCUPAÇÃO \& Conhecimento \& Sugestão Psicologia .................................................109

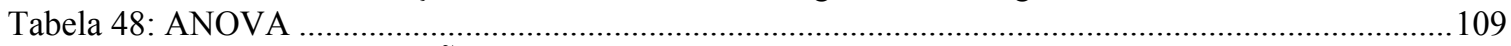

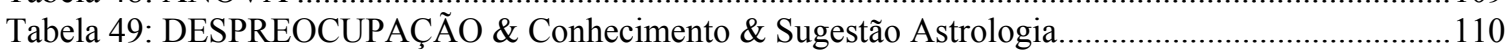

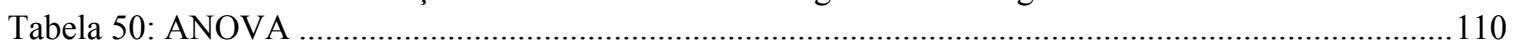




\section{LISTA DE FIGURAS}

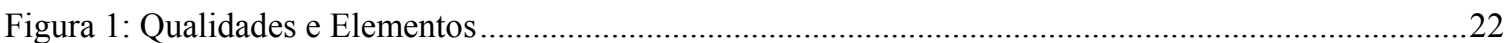

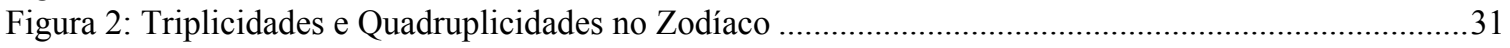

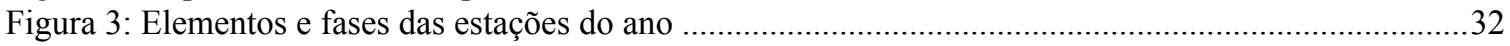

Figura 4: Elementos e estações do ano no Hemisfério Sul.....................................................................33

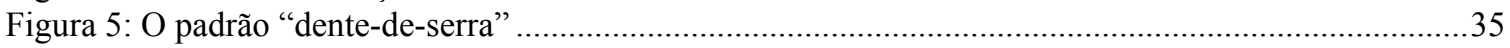

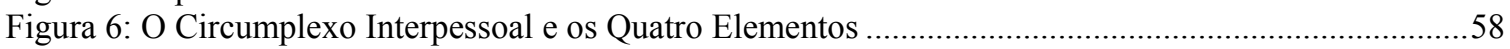




\section{LISTA DE GRÁFICOS}

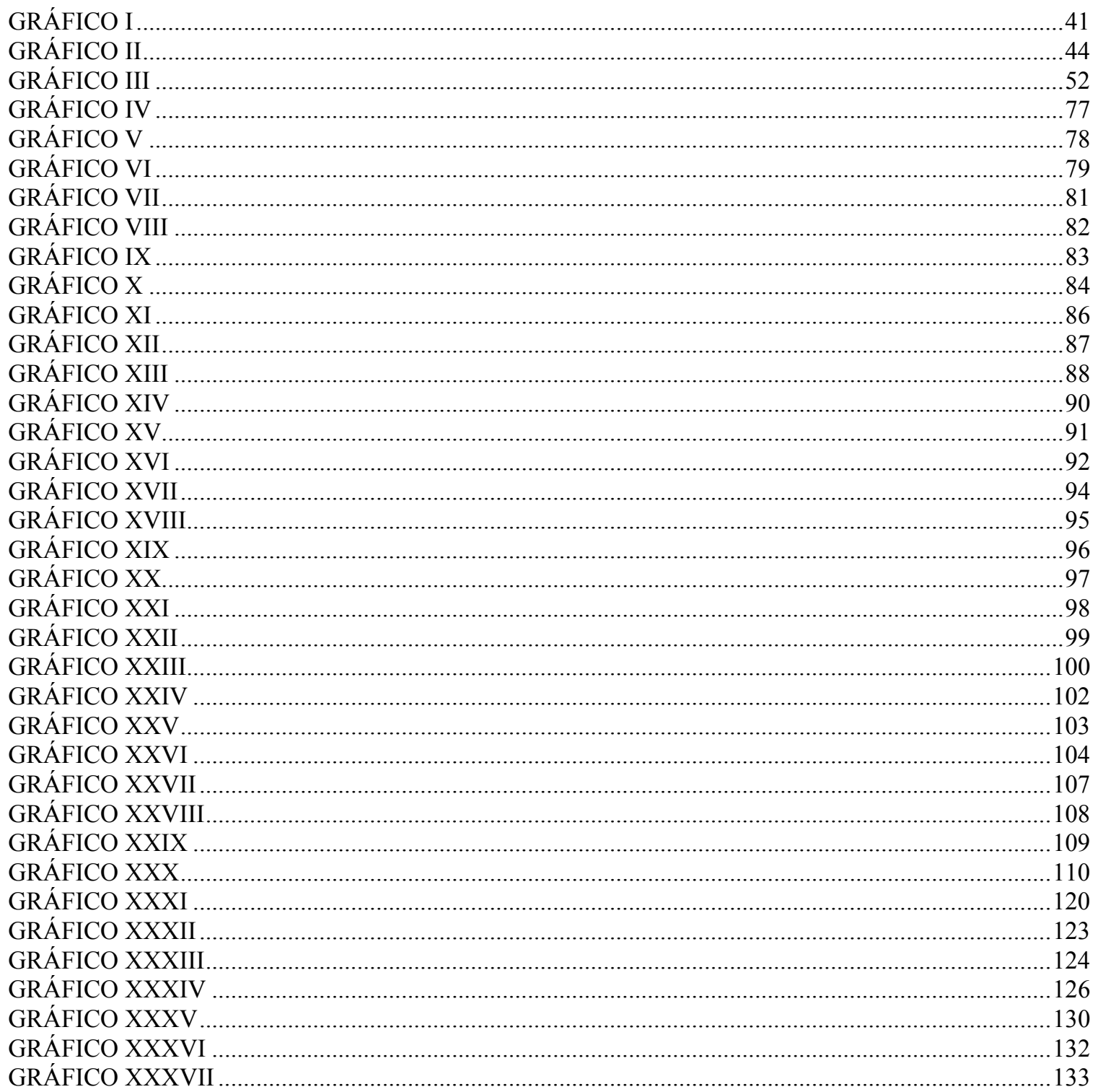


RODRIGUES, Paulo Roberto Grangeiro. Astrologia e personalidade: $O$ efeito do conhecimento das características do signo solar em variáveis medidas pelo $16 \mathrm{PF}$. São Paulo, 2004, 160 p.. Tese de Doutorado apresentada ao Instituto de Psicologia da Universidade de São Paulo.

\section{RESUMO}

Nesta Tese replicamos por constructo uma pesquisa européia que encontrou para conhecedores da astrologia médias mais altas em Extroversão entre sujeitos dos signos de Fogo e Ar comparados com sujeitos de Terra e Água, formando um "padrão dente-deserra" previsto em função da alternância zodiacal entre signos de Elementos Quentes (Fogo e Ar) e Frios (Terra e Água), como sendo efeito da "auto-atribuição", já que a mesma variação não se deu para sujeitos não conhecedores. Também se encontrou, no entanto, maior "suscetibilidade à informação vinda de fora sobre sua personalidade" para os Quentes, o que não invalidou totalmente a teoria astrológica. Encontrou-se lá, além disso, maior média geral em Extroversão para os conhecedores. Usamos o 16 PF Questionário dos 16 Fatores de Personalidade - com 589 sujeitos brasileiros de ambos os sexos, diferenciando entre conhecedores (208) e não conhecedores (381) da astrologia, sendo o conhecimento constituído da crença na astrologia mais a descrição de três características do signo solar. Para estimular a influência da auto-atribuição, foi dada a parte do grupo (266) a sugestão "Esta é uma pesquisa sobre astrologia", enquanto para a outra parte (323) foi dito que seria "uma pesquisa sobre personalidade". Investigamos variações em função dos Elementos astrológicos, através da Análise de Variância (ANOVA), em todos os fatores do 16 PF, mais Extroversão, Ansiedade e Controle. Não aparecem diferenças significativas para a Extroversão isoladamente, mesmo entre os conhecedores. Os conhecedores se descreveram como tendo significativamente maior Extroversão e maior Ansiedade, comparados aos não conhecedores, sugerindo um locus de controle externo. Confirmou-se no grupo dos conhecedores que a maior média geral em Extroversão é devida aos sujeitos do subgrupo dos signos Quentes, e a maior média em Ansiedade é devida aos sujeitos do subgrupo dos signos Frios, indicando a confirmação da maior suscetibilidade à informação vinda de fora sobre suas personalidades para os Quentes. Investigamos, além disso, se a auto-atribuição de origem astrológica afeta não apenas o autoconceito, mas as habilidades da pessoa, através dos 13 itens da Inteligência do 16 PF. Para o grupo de não conhecedores a Ansiedade foi maior para os Quentes do que para os Frios, segundo seus componentes Estabilidade Emocional e Tensão. Este resultado apontou que a Ansiedade, como fator não intelectivo, induziu uma variação de base astrológica na Inteligência. Sugere-se um fator de suscetibilidade diferenciada ao mundo externo segundo a escala Frio-Quente. São analisadas as possíveis explicações teóricas e implicações desses achados. 
RODRIGUES, Paulo Roberto Grangeiro. Astrology and personality: The effect of the knowledge of solar signs's characteristics on variables measured by the 16PF. São Paulo, 2004, 160 p.. Doctorate dissertation presented at the Institute of Psychology of the University of São Paulo.

\section{SUMMARY}

In this thesis we constructively replicate an european research that found for astrology knowledgeable subjects higher means on Extraversion among subjects of Fire and Air signs, compared with subjects of Earth and Water, compound a "saw-tooth pattern" due the zodiacal alternation between signs of Hot (Fire and Air) and Cold (Earth and Water) Elements, as an effect of the "self-attribution", since the same variation was not found for no knowledgeable subjets. Also was found, however, a difference on "susceptibility to information about their personality from outside" for the Hots, what didn't invalidate totally the astrological theory. That research found, furthermore, higher mean in Extraversion for that knowledgeable subjects. We applied the 16PF Test - Sixteen Personality Factor Questionnaire - to 589 brazilian subjects of both sexes, classifying between knowledgeable (208) and no knowledgeable (381) of astrology, being this knowledge constituted by the believe in astrology and by the naming of three characteristics that go with the sunsign. In order to trigger the self-attribution effect, part of the group (266) was given the cue "This is a research into astrology", while to the other part was given "research into personality". We investigate variations by dependence on the astrological Elements, by the Analysis of Variance (ANOVA), on all the 16 PF factors, more Extraversion, Anxiety and Control. Didn't appear significant differences to the Extraversion alone, yet among the knowledgeable. The knowledgeable subjects describe theirselves significantly as having higher Extraversion and Anxiety, suggesting an external locus of control, by comparision with the no knowledgeable. It was confirmed that for the knowledgeable the higher general mean in Extraversion is due to the subjects pertaining to the subgroup of the Hot signs, and the higher general mean in Anxiety is due to the subjects pertaining to the subgroup of the Cold signs, indicating a confirmation of the higher susceptibility to information about their personality from outside among the Hots. We investigate, furthermore, if the astrological self-attribution affects not only the selfconcept, but also the actual performance, with the 13 items of Intelligence in the 16PF. For the no knowledgeable group the Anxiety was higher for the Hots than to the Colds due to their components Emotional Estability and Tension. This finding pointed to that Anxiety, as a non-intellective factor, induced the astrologically based variation for Intelligence. It is suggested, as much to knowledgeable as to no knowledgeable subjects, a factor of differenciated susceptibility to the outer world due the Cold-Hot scale. Are analysed the possíble theoretical explanations and implications of these findings. 
RODRIGUES, Paulo Roberto Grangeiro. Astrologie et Personnalité: L'effet de la conaissance des caractéristiques du signe solaire sur variables mesuré par le 16PF. São Paulo, 2004, 160 p.. Thèse de Doctorat présentée à l'Institut de Psychologie de l’Université de São Paulo.

\section{RÉSUMÉ}

Dans cette Thèse nous répliquons par constructe une recherche européene qui a rencontré pour des connaisseurs d'astrologie des moyennes plus hautes en Extraversion entre sujets des signes de Feu at Air comparés avec de sujets de Terre e Eau, formant un "modèle dent de scie" prévu en fonction de l'alternance zodiacale entre des signes d'éléments Chauds (Feu et Air) et Froids (Terre et Eau), comme étant l'effet de "l'auto-attribution", déjà que la même variation n'a pas été donnée pour des sujets non connaisseurs. Cependant on a recontré aussi, une plus grande "susceptibilité à l'information venue de dehors sur leur personalité" pour les Chauds, ce qui n'a pas invadidé totalement la théorie astrologique. On a trouvé là-bas, en plus de cela, une plus grande moyenne en Extraversion pour les connaisseurs. Nous utilisons le 16PF - Questionnaire des 16 Facteurs de Personnalité avec 589 sujets brésiliens des deus sexes, différenciant entre connaisseurs (208) et non connaisseurs (381) de l'astrologie, la connaissance étant constituée de croyance en l'astrologie en plus de la description de trois caractéristiques du signe solaire. Pour stimuler l'influence de l'auto-attribution, il a eté donné à la partie du groupe (266) la suggestion "Ceci est une recherche sur l'astrologie", tandis que pour l'autre partie (323) il a eté dit que ce serait "ume recherche sur la personnalité". Nous avons investigué des variations en fonction des Éléments Astrologiques, à travers l'Analyse de variance (ANOVA), dans tous les facteurs de $16 \mathrm{PF}$, en plus de l'Extraversion, l'Anxiété et le Contrôle. Il n'apparaît pas de différences significatives pour l'Extraversion isolément, même entre les connaisseurs. Les connaisseurs de sont décrits significativement comme ayant une plus grande Extraversion et aussi Anxiété, si comparés avec les non connaisseurs, suggeránt un locus de contrôle externe. Il est confirmé, dans le groupe des connaisseurs, que la plus grande moyenne en Extraversion est dûe aux sujets du sousgroupe des signes Chauds, et que la plus grande moyenne en Anxiété est dûe aux sujets du sousgroupe des signes Froids, indiquant la confirmation de la plus grande susceptibilité à l'information venue de dehors sur leurs personnalités pour les Chauds. Nous investigons, en plus de ceci, si l'auto-attribution d'origine astrologique affecte non seulement l'auto-concept, mais aussi les habilités de la personne, à travers des 13 articles de l'Intelligence du 16PF. Pour le groupe des non connaisseurs l"Anxiété a été plus grande pour les Chauds que pour les Froids, selon leurs composants Stabilité Emotionnele et Tension. Ce résultat a démontré que l"Anxiété, comme facteur non intellectuel, unduit une variation de base astrologique dans l'Intelligence. On suggère un facteur de susceptibilité differencié au monde externe selon l'echelle Froid-Chaud. Les explications théoriques possibles et implications de ces découvertes sont analysées. 


\section{ASTROLOGIA E PERSONALIDADE: O EFEITO DO CONHECIMENTO DAS CARACTERÍSTICAS DO SIGNO SOLAR EM VARIÁVEIS MEDIDAS PELO 16 PF}

\section{INTRODUÇÃO}

\subsection{ASTROLOGIA E SUA IMPORTÂNCIA NA CULTURA OCIDENTAL}

Onde quer que tenha nascido uma civilização havia uma forma de astrologia, como um conhecimento da ligação entre as coisas do Céu e da Terra. Era uma forma de se compreender e se prever "acontecimentos", dado que se entendia que tudo que acontecia na Terra era resultado de uma influência do Céu. Para isto, antes mesmo de surgir a escrita, surgiram os primeiros observatórios astronômicos, sendo os mais antigos feitos com marcos de pedra, que eram templos ao mesmo tempo. Estudos com monumentos megalíticos têm mostrado que sua função religiosa era antes de tudo relacionada com marcar os movimentos do sol, da lua e das estrelas, prevendo então eventos astronômicos importantes, como máximos e mínimos de afastamentos, e eclipses (PARKER, PARKER, 1982). Um pesquisador da história das idéias, o inglês Peter Marshall (2004), estudou as principais tradições "astrológicas" em diversos centros de civilização do mundo: China, Índia, Mesopotâmia, Egito, Oriente Médio e Europa. Conclui que, por detrás das 
diferenças das imagens, há a mesma busca da compreensão das relações entre os seres humanos, o tempo e o cosmos. ${ }^{1}$

Foi no Oriente Médio que se originou a astrologia que conhecemos hoje no mundo ocidental. Seus primeiros civilizadores construíram observatórios na forma de pirâmides com andares - os zigurates - que permitiam medir e prever os movimentos do sol, da lua e dos planetas, dando-se sempre sobre o mesmo fundo de estrelas, com o que foi possível a criação da faixa circular celeste chamada Zodíaco, por volta de 700 a.C., e dividi-lo em 12 partes - os signos - por volta de 600 a.C.

O Zodíaco atualmente usado no ocidente preserva muito de sua história, suas imagens expressam a necessidade fundamental de determinar as atividades agrícolas e, portanto, as estações do ano, para aqueles povos que ali se fixaram. Desde 3.000 a.C. havia uma divisão - na Pérsia - do céu em quatro partes, pelas quatro estrelas Reais: Aldebaran, ligada posteriormente à constelação Taurus, Regulus, ligada a Leo, Antares, ligada a Scorpius, e Fomalhaut, ligada ao Piscis Austrinus (Peixe Austral), logo abaixo de Aquarius. Estas indicavam o início das estações do ano, quando o sol as alcançava.

As primeiras constelações zodiacais, antes da divisão em doze, foram: Taurus (Touro), Gemini (Gêmeos), Leo (Leão), Virgo (Virgem), Scorpius (Escorpião), Sagittarius (Sagitário) e Pisces (Peixes), estabelecidas pelos caldeus na Mesopotâmia, com seus nomes depois latinizados por Claudius Ptolomeu (Claudius Ptolemaeus) em 140 d.C. Gemini representava a germinação das plantas na primavera. Virgo simbolizava a deusa Istar, filha do céu e rainha das estrelas, coincidindo com a época de colheitas ao fim do verão. Sagittarius representava na Babilônia o deus arqueiro da guerra Nergal. No Egito é

\footnotetext{
1 "At the centre of astrology lies the unfathomable mystery of the correspondence between heaven and earth, of the relationship between ourselses, time and the cosmos" (MARSHALL, 2004, p. 377)
} 
representado como um centauro alado, pronto a flechar o escorpião. Entre os gregos é considerado Quíron, o imortal.

Taurus iniciava o Zodíaco e o ano, há aproximadamente 4.000 anos, entre os babilônios. Com a "precessão dos equinócios", resultado do movimento do eixo terrestre, o equinócio da Primavera desloca-se para trás nas constelações e então Aries ou Carneiro passou a ser a constelação inicial - criada pelos babilônios - por volta de 2.500 a.C. Foram criadas então outras imagens nas constelações para os inícios das estações: Cancer, o caranguejo, foi criado para representar o fato de que no Solstício de Junho o Sol "anda" como aquele animal, de lado - ou seja, de Norte para Sul. Libra, a Balança, foi criada a partir das antigas garras do escorpião, para representar a igualdade do dia e da noite no equinócio do Outono, e também o início da segunda metade do ano que vai equilibrar a primeira. Capricornus, o Capricórnio, criado por caldeus, talvez represente o fato de que as cabras descem as montanhas com a chegada do inverno, e talvez seu rabo de peixe represente esta necessidade de descer para alcançar os vales e rios, ou seja, o Sol que ia cada vez mais longe, com dias cada vez mais curtos no Hemisfério Norte, é representado por um bode que sobe as montanhas, mas seu rabo de peixe é uma "garantia" de que vai voltar ao vale, como o Sol passa a retornar a partir do Solstício de Inverno.

Aquarius, o Aguadeiro, representa as chuvas do mês de Fevereiro, e em antigos monumentos da Babilônia é representado por um homem que entorna água sobre o Peixe Austral (MOURÃO, 1986).

E as imagens do Zodíaco que conhecemos hoje são um fruto final de uma interpretação do ciclo anual naquelas culturas do Mediterrâneo. Os signos expressam, antes de tudo, uma síntese do ciclo das estações do ano conforme simbolizadas em suas etapas, com contribuições das culturas da Babilônia, do Egito e da Grécia, unificadas sob Roma. 
Podemos entender claramente que foram os signos que deram nome às constelações zodiacais, e não o contrário (MOURÃO, 1989), ainda que algumas delas, com Gemini e principalmente Scorpius, possam ter sugerido uma imagem. Porém a atitude religiosa em relação às estrelas fez com que fossem consideradas portadoras do poder de modulação da força ou influência dos planetas que passavam pelas 12 constelações.

A astrologia também passou a ser uma maneira de conhecer as “intenções dos deuses". Desde os seus primórdios a astrologia era ligada à religião, e segundo o movimento dos astros "errantes" poderia haver sofrimentos ou benefícios, o que orientava rituais propiciatórios. Com o tempo, as astrologias ao redor do mundo foram sendo levadas de uma aplicação para o uso religioso de uma civilização para a previsão de destinos individuais, e não apenas dos governantes ${ }^{2}$ (MARSHALL, 2004).

Desde a época das religiões politeístas dominando o Oriente Médio, a astrologia era praticada dentro de uma atividade ritualizada no decorrer do ano. Já no fím do Império Babilônico, os caldeus chamavam os planetas de "intérpretes", porque manifestavam aos homens os propósitos dos deuses, segundo Franz Cumont, arqueólogo e historiador na área das religiões clássicas (1989).

Cumont investigou a astrologia sob o aspecto religioso. Fez uma série de Conferências em 1912 que foram publicadas com o título de "Astrologia e Religião Entre os Gregos e Romanos" ${ }^{3}$ onde se baseia em textos e monumentos antigos para retirar dali suas aplicações naquelas civilizações, e suas idéias básicas. Afirmou ali que “... depois de haver reinado soberana na Babilônia, a astrologia conseguiu fazer sombra aos cultos da Síria e do Egito, e sob o Império - referindo-se ao ocidente - chegou a transformar

\footnotetext{
2 "In the majors traditions of astrology - in China, India, Mesopotamia, Egypt, the Middle East and Europe - there was an early move from predicting the fate of nations to divining the course of individual lives.” (MARSHALL, 2004, p. xxxiv)

${ }^{3}$ CUMONT, Franz ( 1912 ): Astrology and religion among the greeks and romans. 1989.
} 
inclusive o antigo paganismo da Grécia e de Roma." (CUMONT, 1989, p. 9) "Deste modo, o nome dos planetas que empregamos hoje em dia são uma tradução de uma tradução latina, de uma tradução grega, de uma nomenclatura babilônica" (CUMONT, 1989, p. 46). (em todos os trechos fizemos uma tradução livre)

Logo de início percebe-se também a busca de uma vinculação da alma humana com os astros:

"Os caldeus admitiam, ao que parece, que o princípio da vida, que dá calor e anima o corpo humano, era da mesma essência que a dos fogos do Céu. Destes, a alma ao nascer recebe suas qualidades, e neste momento as estrelas determinam seu destino na Terra." (CUMONT, 1989, p. 37)

Na época em que Alexandre Magno conquistou a Mesopotâmia (331-330 a.C.), encontrou lá “...sobre um profundo substrato de mitologia, uma teologia esotérica, baseada em pacientes observações astronômicas, que professavam revelar a natureza do mundo considerado divino, os segredos do futuro e o destino do homem." (CUMONT, 1989, p.

Da Babilônia a astrologia foi levada à Grécia, por filósofos que lá estudaram, e que acrescentaram sofisticações segundo sua abordagem racional:

"Para muitos dos filósofos gregos, não porém certamente para todos, o movimento regular dos céus não é apenas o padrão e a medida do tempo (quando não é identificado com o próprio tempo); serve, também de argumento provando a boa ordem do cosmos, da qual é uma manifestação."

“...sempre é verdade que o sentimento do nexo existente entre a ordem temporal e a ordem moral continua sendo um dos principais temas da concepção grega do tempo e do mundo.” (LLOYD,1982)

Platão e Aristóteles afirmam a divindade das estrelas (estrelas são para eles tanto os planetas quanto as estrelas "fixas"), sendo que Platão chama explicitamente os planetas de 
"deuses visíveis" que estariam abaixo do supremo Ser eterno e perfeito, o qual os anima com sua própria vida. Assim como Pitágoras vê os corpos celestes como “...movidos pela alma etérea que anima o universo e que é semelhante à própria alma humana." (CUMONT, 1989, p. 41)

"Estas doutrinas, que deste modo propagaram-se gradualmente sobre a Grécia clássica, seriam tomadas e transformadas pelos Estóicos. Para os discípulos de Zenon a alma do homem é uma porção do fogo divino em que seu naturalismo panteísta via a força produtiva e a inteligência do mundo. A razão humana, partícula da razão universal, era concebida como alento, como emanação ardente. As estrelas são a mais brilhante manifestação do fogo cósmico. A filosofia do Pórtico favorecia a crença de que a alma era unida com os corpos celestes mediante uma relação especial, e deste modo o Estoicismo conseguiu ser prontamente reconciliado com a astrologia." (CUMONT, 1989, p. 134)

Tanto os "sacerdotes" quanto os "sábios" da época abraçavam as mesmas doutrinas:

"É notável que no séc. II antes da nossa era, esta doutrina foi defendida especialmente por Hiparco, que não era apenas um dos astrônomos mais célebres, mas um adepto convicto das teorias astrológicas,..., foi aplaudido calorosamente por Plínio por ter demonstrado melhor que qualquer um que o homem está relacionado com as estrelas e que nossas almas são "parte do céu"' (CUMONT, 1989, p. 134).

Daí surge a astrologia individual, chamada de Natal ou Genetiálica. (CUMONT, 1989). O Mapa astrológico individual mais antigo que se preservou foi feito em 410 a.C., entre os babilônios, e consiste numa lista da posição no zodíaco da lua e dos cinco planetas para um nascimento. (DEAN \& MATHER, 1977). Há indicações de que se dava importância maior ao "signo lunar" do que ao solar, e isto é esperado, dado que é fácil localizar em qual constelação a lua está passando no período do nascimento de uma pessoa, enquanto a posição solar só pode ser inferida, devido ao próprio brilho do sol. A 
tradição do signo da pessoa ser o lunar foi mantida entre os gregos, ao absorverem o conhecimento astrológico da Babilônia, e foi levada à cultura romana: O Imperador Augustus mandou cunhar moedas de prata com o Capricornus, seu signo lunar conforme o horóscopo que também publicou (DEAN, MATTER, 1977).

Podemos perceber a astrologia daquela época como relacionada a uma astronomia que ficava a serviço da religião, e ainda que Claudius Ptolomeu no seu Tetrabiblos (140 d.C.) descrevesse a influência física dos planetas como causa de seus efeitos baseando-se na física aristotélica, havia uma religiosidade que via os planetas como deuses em si, e era esta a cosmovisão popular.

"Assim, pois, todas estas doutrinas, apesar de suas diferenças em detalhes, pregavam que as almas, descendentes da luz das alturas, reascendiam à região das estrelas, onde moravam para sempre com estas divindades radiantes." (CUMONT, 1989, p. 149)

A astrologia em Roma ganha uma forma final - através dos escritos de Ptolomeu e da religiosidade popular - que se preserva através da Idade Média na Europa, apesar do monoteísmo difundido pela Igreja Católica.

"A imortalidade sideral é provavelmente a doutrina mais elevada concebida pela Antiguidade. Foi nesta fórmula definitiva onde deteve-se o paganismo. Esta crença não pereceria para sempre com ele; e inclusive depois de que as estrelas foram despojadas de sua divindade, chegou a sobreviver em certa medida à teologia que a havia originado." (CUMONT, 1989, p. 149)

Também Ptolomeu conservou os deuses planetários, apenas que ficavam subordinados ao Pai celestial Criador. Isto foi expresso por Marcus Malinus, poeta romano, no século I de nossa era: 
"Pode-se conceber uma máquina mais perfeita em suas atividades, mais uniforme em seus efeitos? Na minha opinião, não penso que seja possível demonstrar com maior evidência que o mundo é governado por um poder divino, que ele próprio é Deus...”

Ptolomeu "situava" Deus além do PRIMUM MOBILE - o "primeiro móvel” - para que pudesse ter dado o impulso inicial nas Esferas (ocas e cristalinas) das Estrelas Fixas e dos Planetas abaixo desta, centradas no centro imóvel da Terra. Depois, preservou-se naquele lugar externo um Céu, morada do "Altíssimo" dentro da Teologia cristã. Mas Ptolomeu também coloca o sol como o mais importante dos planetas, o "coração do mundo", e talvez tenha sido quem iniciou a tradição de se considerar como o signo da pessoa o solar, ou seja, aquele onde o sol estava em seu nascimento:

"O Sol se transformará no condutor da harmonia cósmica, no mestre dos quatro elementos e das quatro estações... Plínio já o reconhecia como a divindade soberana que governava a natureza,.... Ele será visto por teólogos pagãos como a razão que controla o mundo, mens mundi et temperatio.” (CUMONT, 1989, p. 72-73)

Sob a influência de teólogos cristãos, no entanto, a astrologia na Europa foi cada vez mais tornada um conhecimento herético; conservando-se, porém, como uma atividade secreta, e praticamente solitária, tanto quanto a alquimia.

Havia no mundo católico uma tentativa de subjugação dos deuses astrológicos a um grande Deus que estava até mesmo além de Zeus - Júpiter, e que se colocava além da última esfera do mundo. No máximo, tolerava-se a idéia da utilidade da astrologia explicar acontecimentos no mundo físico. Mas então, segundo certas filosofias não referendadas pela doutrina católica, apenas se reconhecia o universo físico observável como efetivo, e se Deus existisse além das Estrelas Fixas era um "deus ocioso", que deixara a Criação pronta e se retirara. Houve muitas controvérsias entre a religião e a astrologia na Idade Média.

\footnotetext{
4 in "Os astrológicos", citado em Vilhena, R., 1990.
} 
São Tomás de Aquino, no séc. XIII a aceitava somente enquanto aplicada a "fenômenos naturais" (PARKER, PARKER, 1986), já então considerando a alma como metafísica: os “corpos celestes" podiam influenciar apenas indiretamente a condição do entendimento. No entanto não era vivido assim entre os alquimistas e os astrólogos ${ }^{5}$ : havia um propósito espiritual em suas atividades. Se de um lado a astrologia tratava da "encarnação" do espírito, passando pelas forças dos céus planetários até entrar num corpo, a alquimia tratava da "espiritualização" da matéria ou do corpo, libertando o espírito, através da relação adequada com os “metais” planetários (JUNG, 1986; 1991).

Com o Renascimento a astrologia também é retomada como toda cultura dita Clássica. Ela era uma das formações oferecidas nas primeiras Universidades européias, e assim permaneceu durante todo o período do Renascimento. Foi uma cadeira universitária, por exemplo, desde 1125 em Bolonha, e desde 1250 em Cambridge.

Com a criação da imprensa, a astrologia passou a ser popularizada através de "Almanaques", cujos calendários orientavam quanto às épocas de atividades agrícolas, mas, além disso, recomendavam sobre as épocas mais indicadas para atividades sociais.

Há um renascimento também de seu aspecto religioso, mais além de sua expressão como estudo da astronomia e suas conseqüências na natureza. Filósofos como Marsilio Ficino deram novamente vida à astrologia no séc. XV, na Itália, e praticavam com esta um politeísmo da imaginação, como denota esta sua passagem em "O livro da Vida": "Não há Saturno mais insensível do que aquele para os homens que só fingem levar uma vida contemplativa, sem na verdade vivê-la. Pois Saturno não os reconhece como seus (...) Certifique-se de não negligenciar o poder de Saturno." ${ }^{\text {. }}$

\footnotetext{
${ }^{5}$ cujas publicações foram analisadas por Mircea Eliade e Carl Gustav Jung.

6 “ The book of life”, Dallas, Texas: Spring Publications, 1980, pp.165-6 . Citado por SULLIVAN, 1992.
} 
Com o acúmulo do conhecimento científico na Europa, diversas descobertas fizeram a astrologia ser gradualmente considerada não científica e acabar por ser banida das Universidades. O geocentrismo de Copérnico em 1543; o surgimento de uma "nova estrela" em 1572 que motivou Johannes Kepler a escrever um livro sobre ela; a invenção do telescópio em 1610 e seu uso sistemático por Galileu Galilei com a descoberta de novas estrelas e finalmente de um cosmos infinito, ou ao menos não restrito à Esfera das Estrelas Fixas (KOYRÉ, 1979).

Tycho Brahe e seu sucessor Johannes Kepler foram ao mesmo tempo astrônomos e astrólogos, nesta época de transição, no qual um novo "paradigma científico" ainda convivia com o antigo (KUHN, 1962). Kepler chegou a escrever que a astrologia era: "...filha tola e infame da astronomia, sem a qual a velha e sábia mãe morreria à míngua." (PARKER, PARKER, 1986, p.188)

Ainda houve tentativas de se fazer uma astrologia científica, e o autor mais conhecido deste período é Jean-Baptiste Morin, astrólogo da corte francesa e autor de uma enorme obra intitulada "Astrologia Gallica". Morin tentou fazer da astrologia uma ciência exata, estabelecendo regras para a interpretação dos Mapas Astrológicos individuais através das quais seriam previstos acontecimentos concretos. Parece que estas tentativas propiciaram ainda mais sua rejeição pelos "astrônomos".

A partir de 1666, na França, a astrologia passou a ser banida das Universidades. Foi por mão dos cientistas que a astrologia acabou sendo descartada das Universidades, não devido ao politeísmo implícito, mas por adotar o geocentrismo derrubado por Nicolau Copérnico e Johannes Kepler. Quando a Astronomia superou o geocentrismo, houve uma grande oposição à astrologia, pois esta só poderia continuar adotando a Terra como centro para as medidas astronômicas, pois o que é o centro ali é o indivíduo nascente, ou o lugar para onde se quer enfocar as influências astrais. 
Somente mais de dois séculos depois ressurgiu valorizada no Ocidente, principalmente por mão dos Teosofistas, que mesclando conceitos religiosos orientais com os ocidentais, buscavam uma unidade da qual a astrologia fazia parte, pois, por exemplo, na Índia nunca fora banida dos centros cultos, como no Ocidente. Resgataram principalmente seus aspectos esotéricos, relacionando suas influências principalmente com o "plano astral" onde habitaríamos com nosso "corpo astral". Assim desde esta época a astrologia está relacionada ao esoterismo e suas diversas correntes no Ocidente. Houve uma certa revivescência da astrologia nos anos 60 e 70 do século XX, muito em função da "Contracultura", que fomentou tanto os esoterismos quanto as doutrinas e religiões orientais.

Com o desenvolvimento da Psicologia há no século XX um relacionamento entre astrólogos e psicólogos que denota rejeições e influências mútuas. Temos por exemplo um filósofo e astrólogo franco-americano, Dane Rudhyar, que iniciou sua obra teorizando sobre astrologia dentro da visão teosófica e acaba por relacioná-la com a psicologia da personalidade (1989). Temos André Barbault, astrólogo francês, que relaciona a teoria astrológica do caráter com a Psicanálise (1975). E Carl Gustav Jung, psiquiatra e teórico da "psicologia do inconsciente", que vê na astrologia "a somatória do todo o conhecimento psicológico da antiguidade" (1983, p. 143), e em seu simbolismo uma maneira de expressar o que conceituou como o "inconsciente coletivo" (1968). Conforme resumiu:

"Como é sabido, a ciência começou com os astros, nos quais a humanidade descobriu seus dominantes do inconsciente, ou seja as chamadas divindades, do mesmo modo as singulares qualidades psicológicas do Zodíaco constituem toda uma teoria projetada de caracteres" (1986). 
Jung foi um dos pioneiros na pesquisa psicológica da astrologia, avaliando estatisticamente as relações entre os Mapas astrológicos de 483 casais na década de 1950, com resultados favoráveis à astrologia, porém inconclusivos (JUNG, 1952).

A maioria dos astrólogos ocidentais contemporâneos pratica uma "astrologia psicológica", iniciada por astrólogos como André Barbault (1975), Dane Rudhyar (1989, 1985b), e Stephen Arroyo (1986), que considera o mapa astrológico do nascimento como um símbolo da psique, com sua divisão entre consciente e inconsciente. Foram influenciados principalmente por Jung. Consideram que há uma "sincronicidade" (JUNG (1952), 1985) entre os eventos celestes e os estados psíquicos, assim o simbolismo astrológico pode ser usado para interpretar e ordenar a experiência cotidiana. ${ }^{7}$

Temos até hoje no mundo ocidental a astrologia sendo ensinada em cursos livres, em geral ligados a associações astrológicas. Os astrólogos ocupam espaço na MIDIA, e temos uma vasta publicação - livros e softwares - não só divulgando a astrologia como ensinando suas técnicas básicas de cálculo e interpretação de Mapas Astrológicos. Uma pesquisa do Instituto Gallup, feita com adolescentes norte-americanos entre 13 e 18 anos em 1983, mostrou que 55\% deles acreditam que a astrologia funciona. Não há razões para crermos que isto tenha mudado muito neste início do terceiro milênio.

Houve também uma intensificação das pesquisas das correlações com Psicologia que vem até nossos dias. Um pesquisador que fez história foi Michel Gauquelin, psicólogo e estatístico francês que desde a década de 50 fez amplos levantamentos (dados de mais de 100.000 pessoas) e estudos de correlação. Vamos nos deter um tanto em suas pesquisas, porque algumas confirmações que obteve deram alento à consideração contemporaneamente dada à astrologia por parte da comunidade científica, e nos incluímos

\footnotetext{
7 "The modern psychological approach to astrology sees the correlations in a birthchart between the planets and personality traits as being mainly symbolic". "From this perspective, astrology offers a rich symbolic language which can be used to interpret human experience and to order and understand our feelings". (MARSHALL, 2004, p. 361)
} 
nesta linha de investigação. Suas pesquisas demonstram, na maior parte dos casos, que a astrologia conforme praticada pelos astrólogos contemporâneos não funciona (1983). No entanto Gauquelin ficou conhecido pelo chamado "Efeito Marte" (Mars Effect), ao demonstrar que a eminência nos esportes se relacionava a Marte colocado em posições específicas, ou logo após levantar no leste ou logo após culminar, quando do nascimento dos futuros campeões esportivos. Isto independentemente do Zodíaco, o qual rejeitou como sendo ficção. Do mesmo modo demonstrou estas relações para outros planetas com profissões astrologicamente relacionadas: Marte também com militares (marciais), Júpiter com atores e políticos (pessoas extrovertidas), Saturno com cientistas (pessoas reflexivas), e também da Lua com escritores (imaginativos), numa amostra total de $46.485 \operatorname{casos}^{8}$.

Neste ínterim foi publicado em 1977 o livro Recent advances in natal astrology: a critical review 1900-1976, de Geoffrey Dean e Arthur Mather, com mais 52 colaboradores. Lá se comentaram, analisaram e replicaram amplamente também esta e outras pesquisas de Gauquelin. Em 1981, Dean e Mather, entre outros cientistas, lançaram a revista “CORRELATION - Journal of Research into Astrology”, tendo Michel Gauquelin e Hans Eysenck - iniciador da linha de pesquisa em que adentramos com esta Tese - entre seus colaboradores.

Foi nesta mesma revista que todo o trabalho de Gauquelin foi revisto, com um forte questionamento através de explicações alternativas para seus achados. O "Efeito Marte" passou a ser visto como resultado possível de uma "profecia auto-realizadora" associada a uma construção social (BERGER, LUCKMANN, 1974) da eminência, já que Gauquelin baseou sua medida de eminência nas citações biográficas. (KELLY, DEAN, SAKLOFSKE, 1990).

\footnotetext{
${ }^{8}$ Estas pesquisas foram extensamente comentadas em nossa Dissertação (RODRIGUES, 1997)
} 
No entanto há algo demonstrado por Michel e Françoise Gauquelin, sua esposa e colaboradora, que não foi refutado, ainda que não tenha sido totalmente explicado: A chamada "hereditariedade planetária", que já havia sido apontada por Kepler, ao publicar que "Há um argumento perfeitamente claro além de toda exceção em favor da autenticidade da astrologia. É a conexão horoscópica comum entre pais e filhos."9 Gauquelin demonstrou com 35.907 pares de pais e filhos que os filhos tendem a nascer naturalmente em horários que permitam repetir dos pais as posições "angulares" dos planetas lua, Vênus, Marte, Júpiter e Saturno, ou seja, próximos aos eixos horizontal e vertical, mais fortemente logo após ter passado por eles ${ }^{10}$.

Gauquelin conclui pela "diferença de sensibilidade biológica" aos planetas, cada pessoa teria diferentes sensibilidades às "influências" dos planetas, e isto passaria geneticamente de pais para filhos. Gauquelin reinterpreta então a relação planetaseminência não como uma causalidade planetas - profissões, mas como uma influência planetas - traços de personalidade relevantes, os quais por sua vez levariam a escolhas profissionais afins com estes. Deste modo fica compreensível a relação com a possível eminência, aí sim um caso de um tipo de profecia auto-realizadora (EDEN, KINNAR, 1991) que cresceria num campo fértil de uma predisposição biológica. Porém isto só ocorreria nos partos naturais, demonstrando não haver uma relação direta de causalidade, mas sim uma espécie de sincronia entre ritmos biológicos e movimentos planetários do ponto de vista geocêntrico. Veremos adiante com esta assunção é crucial, pois esta correlação poderia ser um resultado evolucionário da espécie em função da forma de funcionamento emocional e das crenças dos antepassados humanos. É claro que estas proposições já não se relacionam com as da astrologia conforme é divulgada e praticada

\footnotetext{
9 "There is one perfectly clear argument beyond all exception in favour of the authenticity of astrology. This is the common horoscopic connection between parents and children.” In EYSENCK, NIAS, 1982, p. 191.

${ }^{10}$ Em nossa Dissertação (1997, p. 30-46) descrevemos detalhadamente estas pesquisas.
} 
hoje. Ainda hoje no ocidente a astrologia com base em Ptolomeu é amplamente divulgada e consumida dentro da cultura de massa, a despeito de que até agora a avaliação científica de suas proposições tradicionais tenha demonstrado amplamente que não têm validade (CROWE, 1990; KELLY, 1998). Torna-se então um fenômeno a ser estudado sob a ótica de sua utilidade social e psicológica, ou seja, saber porque grande parte das pessoas acredita na astrologia e a utiliza. 


\section{2. “A SOMATÓRIA DE TODO O CONHECIMENTO PSICOLÓGICO DA ANTIGUIDADE"}

É evidente que a astrologia respondia antes de tudo a um anseio religioso de harmonia entre terra e Céu, cumprindo também uma função de ordenação da vida comunitária, permitindo a previsão do futuro cósmico, e do futuro social por conseqüência. A astrologia buscava desde seu início apreender a "ordem celeste" para criar rituais cíclicos em consonância com os ritmos observados. Mais ainda, serviu para criar uma forma de prever os movimentos dos deuses, e assim de uma certa forma prever problemas ou facilidades.

No âmbito da "consciência coletiva" de uma tribo, de um povo ou de uma nação, há sempre um "sistema mágico-classificatório" compartilhado, como sistema explicativo do mundo, (um "mapa de realidade"), que é útil porque funcional para a sobrevivência do grupo. Segundo o antropólogo Lévi-Strauss, estes sistemas sempre caminham paralelos, no conhecimento da natureza, ao que seria uma visão propriamente "científica" nos moldes modernos. O "pensamento selvagem”, também chamado de "pensamento mágico", propõe sistemas classificatórios baseados na natureza, e, no caso, os astros são "bons para pensar", pois "propõem ao homem um método de pensamento". (VILHENA, 1990)

Há uma ordem, regularidade e ciclicidade nos movimentos do céu, somados ao seu caráter de abrangência em relação à Terra, que foram sempre - e em todos os lugares relacionados com a organização humana coletiva, notadamente a divisão das atividades coletivas segundo o dia , o mês e o ano, ligados respectivamente com a Terra, a lua e o sol.

Estas classificações passam a estruturar a vida coletiva em seus rituais diários, mensais, anuais e outros maiores, relativos a planetas "além" do sol. Assim atuando, o "pensamento mágico" "elabora estruturas organizando acontecimentos." 
Há então na astrologia uma proposta de ser um conhecimento fundamental e permitir uma visão totalizadora. Teóricos em astrologia sustentam que seu princípio de atuação é a ANALOGIA, semelhança ou correspondência, desde o séc. III a.C.:

“O QUE ESTÁ EMBAIXO É COMO O QUE ESTÁ EM CIMA, O QUE ESTÁ EM CIMA É COMO O QUE ESTÁ EMBAIXO”, é um dos seus principais aforismos, atribuído ao mítico Hermes Trimegistus, autor presumido da Tabula Smaragdina (JUNG, 1991).

Este caráter religioso da astrologia é o que lhe causa as maiores críticas advindas dos cientistas contemporâneos, quanto às pretensões de ser ciência ou ser um meio de previsão de acontecimentos. Há uma confusão entre sua funcionalidade social e sua verdade como sistema explicativo da realidade.

Para a Psicologia social podemos entender a astrologia como um sistema que interpreta o mundo segundo necessidades psicológicas humanas, fornecendo os "astros" ordem e regularidade, através das quais se pode predizer, e daí tentar controlar. O ser humano "primitivo" divide o mundo entre guiado por deuses bondosos e desviado por deuses maléficos. Ora, nos cultos há um caráter de "troca" com os deuses, na busca de evitar malefícios e obter benefícios, em geral a partir de sacrifícios. Numa teoria psicológica contemporânea, estes rituais de base astrológica defendem o grupo social contra "ansiedades depressivas" e "ansiedades paranóides", ou seja, esconjuram, apaziguam ou propiciam forças fora do controle imediato do ser humano, representadas nas divindades astrais portadoras de forças destrutivas ou protetoras para o ser humano (JACQUES, 1969).

É compreensível que no mundo contemporâneo tenha havido uma revivescência da astrologia, dado a incerteza e a confusão da vida social, e a solidão a que o individualismo predominante leva. Uma pesquisa sobre o perfil psicológico de pessoas que consultam 
astrólogos delineou o maior fator em comum como sendo o estresse, mais especificamente relativo aos papéis sociais e aos relacionamentos (TYSON, 1982).

Hoje, esta relação com os astros já se dá de forma mais individualizada, através dos mapas astrológicos e suas derivações. A astrologia é uma formação profissional alternativa e livre, com seus clientes advindos de diversas classes sociais e denominações religiosas, conforme demonstrado no estudo antropológico de Luís Rodolfo Vilhena com astrólogos e estudantes de astrologia no Rio de Janeiro (1990).

Cabe perguntar se a astrologia é hoje apenas um sistema de crenças que ajudam parte da população a suportar melhor as contingências da vida urbana, ou se não haveria de algum modo uma verdade em suas afirmações sobre as diferenças de personalidade e destino determinadas pelos signos e planetas ao nascer. Como vimos, a primeira idéia de destinação celeste individual era que isto se dava principalmente através do chamado signo lunar, mas logo mudou para o signo solar, provavelmente em função da cultura romana que promovia nos cidadãos uma afirmação individualista, o que encontra evidentemente melhor analogia no sol do que na lua. E assim é divulgada, atraentemente, até hoje.

Ao afirmar a unidade da alma com os astros, a astrologia permitia (e permite hoje para os seus crentes) uma relação humana com a divindade e a conseqüente possível imortalidade, pela idéia da relação do sol com o espírito. E esta é a forma mais popular e contemporânea da astrologia no mundo ocidental, aquela relativa ao signo solar do nascimento.

Não haveria alguma verdade oculta na idéia de predestinação astral, já que tantos que tomam contato com isso continuam sendo adeptos? Não será que a astrologia natal "funciona" de algum modo, e isto seja o fator preservador da crença? Ou mesmo a crença de nossos antepassados, de tão forte, não se tornou de algum modo predisponente da realidade das diferenças individuais? 
Uma pesquisa de 1997 sobre correlações entre signos e dados biográficos (SACHS, GUNTER, citado in KNIGHT, LOMAS, 2004), realizada com a amostra de praticamente toda a população suíça contada pelo censo de 1990, revelou algumas diferenças estatisticamente significantes em dez critérios: Numa amostra de 771.226 pessoas casadas, encontrou 25 pares mais freqüentes do que os 144 possíveis $(\mathrm{p}<0,00002)$. Já entre 109.030 pares de divorciados, encontrou outros 25 pares mais freqüentes $(p<0,04)$. Entre 2.731.766 pessoas entre 18 e 40 anos de idade, encontrou sete signos mais solteiros ( $\mathrm{p}<$ 0,0001). Nas escolhas de dez cursos universitários, isolou 27 desvios muito significativos ( $\mathrm{p}<0,0000001)$. Entre os 4.045.170 trabalhadores da Suíça em 1990, avaliou a colocação em 47 categorias de trabalho, encontrando 77 desvios significativos $(p<0,0000001)$. Quanto ao tipo de morte por 20 causas naturais, entre 1969 e 1994, isolou uma relação com cinco desvios significativos $(p<0,004)$. Suicídios com cinco desvios $(p<0,001)$. Entre os problemáticos no trânsito, encontrou quatro signos mais freqüentes na Inglaterra em 1996 $(\mathrm{p}<0,0000001)$, e os mesmos quatro signos $(\mathrm{p}<0,0002)$ na Suíça como infratores de trânsito! Em 325.866 julgamentos de 25 tipos de crime na Suíça, encontrou seis combinações significativas $(p<0,0000001)$. Finalmente, entre 4162 jogadores profissionais de futebol na Alemanha, encontrou nove signos desviantes $(\mathrm{p}<0,0000001)$.

Ao comparar estes resultados com os de doze signos criados aleatoriamente, as diferenças se confirmaram. Há alguma coisa, entre os signos e os comportamentos, que pode não depender da pessoa saber sobre seu signo astrológico, que vale pesquisar. 
As pesquisas que acompanharemos agora são aquelas iniciadas por Eysenck na década de 70 e referem-se a este signo solar, avaliando se de fato as pessoas se diferenciam em termos de personalidade por terem nascido em diferentes signos. Estas diferenças seriam advindas basicamente de Elementos e Ritmos a que pertencem estes signos, sendo isto uma sofisticação adicional da astrologia, como explicaremos em seguida.

Se há de fato determinações astrológicas de características psicológicas, estas seriam capturáveis por questionários de personalidade aceitáveis segundo critérios psicométricos rigorosos (KLINE, BARRETT, 1983), com o criado por Eysenck (1973). E é o que foi inicialmente avaliado, com resultados inesperados tanto para astrólogos como para psicólogos, como veremos depois. 


\subsection{O CÍRCULO ZODIACAL E A HARMONIA DOS ELEMENTOS}

É preciso antes - para se poder compreender as variáveis astrológicas e as correlações entre elas e as variáveis de personalidade - lembrar que a subdivisão do ano em 12 partes iguais é uma abstração, indissociável da teoria dos quatro Elementos: Fogo, Terra, Ar e Água. São, na teoria aristotélica, "elementos" fundamentais na constituição de tudo, substâncias resultantes da interação das outras duas fundamentais: Matéria e Idéia. Daí a relação com a altura do mundo na cosmologia de Aristóteles, indo do mais sólido, as rochas da Terra, até o fogo celeste, eterno e intermediário entre a Divindade e o ser humano. Mais ainda, como estes extremos compartilham a secura, para a criação da vida e para a nossa sobrevivência existem as combinações entre estes extremos que a umidade traz, o Ar e a Água. E somos compostos por estes Elementos, pois somos em parte sólidos, em parte líquidos e em parte gasosos, mas mais ainda, com uma alma composta de Fogo, luminosa ao se desprender do corpo, daquela mesma luz da superfície do fogo. Isto colocado sob um ponto de vista da Física contemporânea levaria à conclusão de que esta luz compartilhada com as estrelas nos tornaria “radiantes". É que esta luz é que era a razão de se compreender uma ligação íntima com o cosmos, pois se entendia que tanto a alma provinha de Fogo celeste do Sol e das Estrelas quanto para lá voltaria, se virtuosa. ${ }^{11}$

Claro que também se pode entender nesta visão de mundo um pensamento concreto, no qual a observação da natureza leva a perceber regularidades e ciclos. Há uma dependência estrita das imagens da natureza, relacionando tudo por um princípio básico, ou por alguns princípios básicos que se relacionariam de forma compreensível geometricamente, ou seja, com padrões qualitativos (DURAND, 1988).

\footnotetext{
${ }^{11}$ CUMONT, Franz ( 1912 ): Astrology and religion among the greeks and romans. 1989.
} 
Podemos adotar o ponto de vista que vai compreender a teoria dos Elementos como uma física primitiva, que tenta uma primeira generalização de leis através da percepção do que hoje se entende como sendo quatro estados da matéria. Desta forma permite relacionar tudo com tudo o mais que existe por uma categorização por analogias, em busca de revelar uma "ordem" no mundo. Podemos também perceber aí o predomínio do pensamento mais tarde chamado de representativo concreto por Jean Piaget, com a característica fundamental de egocentrismo, por depender muito da observação concreta feita pelo próprio sujeito pensador.

Porém também podemos compreender a teoria dos Elementos como utilizando-se das "categorias fundamentais da imaginação", no dizer de Gaston Bachelard ((1938), 1990), ao escrever sobre os quatro Elementos ao longo de sua carreira de filósofo. De fato são, antes de imaginárias, categorias sensoriais combinadas em qualidades diferentes: o calor e a umidade. A polaridade frio-quente em interação com a polaridade seco-úmido geram quatro combinações, expressas nos quatro Elementos, como pode ser visto na Figura 1.

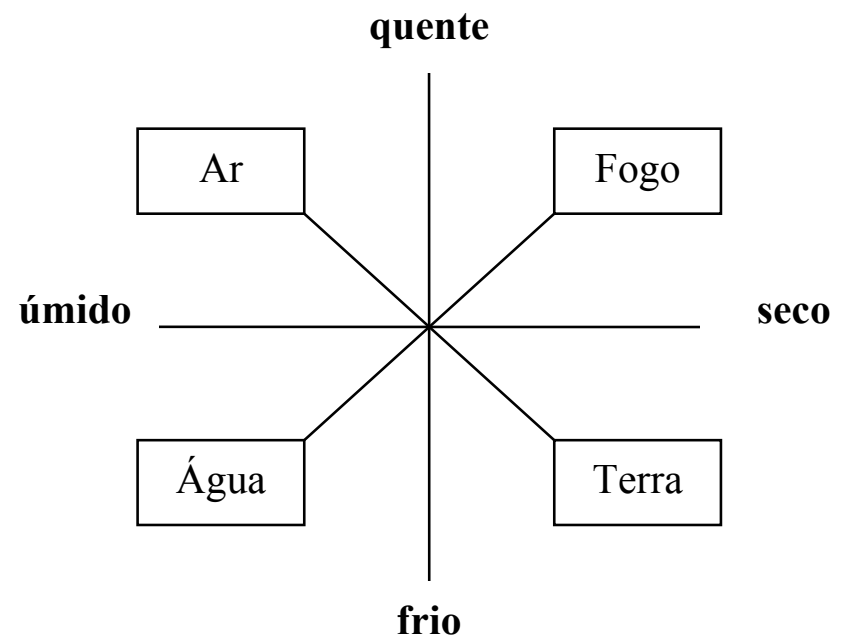

Figura 1: Qualidades e Elementos 
Os extremos secos se diferenciam entre si pelo fato do Fogo ser quente, tendente a subir, e a Terra fria, tendente a cair. Esta dimensão se relaciona à altura, como já descrevemos no início. Portanto a outra dimensão fundamental é dada pela umidade, que na Água compartilha a frieza da terra, e no Ar compartilha o calor do Fogo. Mas não existe umidade nem no céu nem na Terra pura, que é a rocha que se transforma em areia e pó. E como a umidade também se espalha pela Terra, expandindo e contraindo, tem seu predomínio em nosso plano horizontal da vida terrestre.

Podemos perceber por esta teoria que o Fogo e a Água são opostos totalmente por não compartilharem nenhuma qualidade sensorial: quente e seco contra frio e úmido, mas há dois intermediários entre eles que também são opostos totalmente entre si, o Ar e a Terra. A Água pode assumir a forma sólida, mais próxima da Terra, e a forma gasosa, mais próxima do Ar. O calor do Fogo realiza isto sobre a Água, ao passo que a Água pode extinguir o Fogo aqui na Terra, mas o Fogo celeste é eterno e imutável.

Quanto à Terra em relação ao Ar: fria e seca contra quente e úmido, se opõem por uma tendência a formas fixas contra formas voláteis, de modo que a Terra suporta tudo, mas não se mistura com nada, enquanto o Ar se envolve tanto com a Água quanto com o Fogo, até mesmo com a Terra, esculpindo suas formas expostas ao seu contato.

O Cosmos é então o funcionamento harmonioso da interação entre os quatro Elementos, unificados por um substrato para todos, o Éter. 
Mas, então, como estes quatro Elementos vieram parar no Zodíaco?

Esta é provavelmente a principal contribuição grega à astrologia que receberam dos caldeus. Há uma inserção geométrica dos Elementos no Zodíaco, assim transcende-se as imagens das constelações e cria-se um Zodíaco matemático, chamado "noetà zodia": um zodíaco mental. Inicialmente este Zodíaco utilizado pelos gregos estabelece uma relação "diacrônica" entre os Elementos, já que este expressa o ciclo do ano dividido em doze etapas. Portanto há uma relação estrita com o relacionamento Terra - Sol e suas conseqüências. Este gera as quatro estações do ano, iniciadas matematicamente: Primavera e Outono por um dos Equinócios nos quais o sol incide diretamente sobre o Equador igualando o dia e a noite, Verão e Inverno por um Solstício no qual o sol incide perpendicularmente num dos dois Trópicos. Cada estação do ano passou a ser subdividida em três etapas, muito provavelmente em função da relação com três ciclos lunares completos - em média - em cada uma, mais a idéia de cada uma ter Começo, Meio e Fim. Assim, a partir dessa idéia da subdivisão das estações em três etapas, em que cada uma delas caracteriza um Ritmo astrológico, passou-se a entender que o signo relativo a cada uma dessas três etapas seria respectivamente Cardinal (ou Cardeal), Fixo e Mutável (ou Móvel). Ptolomeu em 140 d.C., os descreveu respectivamente como SolsticiaisEquinociais, Sólidos e Bicorpóreos, como veremos adiante, formando - sincronicamente quadrados no Zodíaco, chamados de Quadruplicidades. Ptolomeu descreve a relação de domínio do céu sobre a Terra através dos Elementos: 
“... um certo poder emanando da etérea substância eterna é disperso através de, e permeia toda a região em volta da terra, a qual em toda parte é sujeita à mudança, uma vez que, elementos sublunares primários, fogo e ar são envolvidos e mudados pelos movimentos no éter, que por sua vez envolvem e mudam tudo o mais, terra e água e as plantas e animais ali dentro. $^{12}$

Para explicar as diferenças entre as quatro estações, Aristóteles utilizou-se das escalas do calor e da umidade, com cada qualidade do extremo delas predominando numa estação: o quente no verão, o frio no inverno; o úmido na primavera, o seco no outono. A partir daí há uma correlação possível com a idéia dos Elementos. Dado que o Zodíaco expressa a relação Terra - Sol fica fácil perceber que só o elemento Fogo do qual o sol é composto pode predominar no meio do verão. Portanto o signo do meio do verão, Leão, só pode ser do Fogo. Os outros três Elementos são então dominantes no meio das outras estações. Oposto a Fogo do meio do verão deveria estar Água no meio do inverno, com o signo Aquário, poderíamos pensar. Mas o que os antigos astrólogos determinaram e Ptolomeu consolidou para a posteridade é que o Ar é que se opõe ao Fogo no Zodíaco. No entanto Ptolomeu não explica totalmente isto, apenas afirma o que foi dado pela tradição:

“... o próximo assunto a ser tratado seria o dos caracteres naturais dos signos zodiacais em si mesmos, como foram passados por tradição. Porque embora seus temperamentos mais gerais são para cada um análogos às estações que ocorrem neles, certas qualidades peculiares deles surgem do seu parentesco com o sol, a lua e os planetas..."13

\footnotetext{
${ }^{12}$ a certain power emanating from the eternal ethereal substance is dispersed through and permeates the whole region about the earth, which throughout is subject to change, since, of the primary sublunar elements, fire and air are encompassed and changed by the motions in the ether, and in turn encompass and change all else, earth and water and the plants and animals therein.

O texto do Tetrabiblos está em www.geocities.com/astrologysources/classicalgreece/tetrabiblos/, em 25/03/2003.

${ }^{13}$ Livro I: “...the next subject to be added would be the natural characters of the zodiacal signs themselves, as they have been handed down by tradition. For although their more general temperaments are each analogous to the seasons that take place in them, certain peculiar qualities of theirs arise from their kinship to the sun, moon, and planets..."
} 
Ou seja, um signo pode se diferenciar da qualidade dominante da estação por ser "regido" por um dado planeta ou um dos "luminares", devido a estes também terem qualidades segundo as polaridades Frio-Quente e Seco-Úmido, algo em parte definido por sua posição em relação ao sol.

Em seguida Ptolomeu descreve que estes signos do meio das estações têm seus Elementos determinados não pelos planetas, mas por uma relação indireta com as estações.

“Os signos sólidos, Touro, Leão, Escorpião e Aquário, são aqueles que seguem os signos solsticiais e equinociais; e são assim chamados porque quando o sol está neles, a umidade, o calor, a secura e o frio das estações que começam nos signos precedentes nos tocam mais firmemente; não que o clima seja mais naturalmente um pouco mais destemperado naquele tempo, mas é que nós estamos então acostumados a eles e por esta razão somos mais sensíveis ao seu poder."14

No entanto Ptolomeu ainda não explica o porquê de ser o Ar e não a Água, ou mesmo a Terra, o Elemento do signo Aquário, devido ao predomínio da frieza quando o sol está passando nele em pleno inverno, sendo o Ar quente e úmido. Esta aparente incoerência chegou a levar um dos maiores astrólogos árabes, Albumansur ou AbouMashar (805-885) a propor uma mudança na classificação aristotélica dos Elementos, fazendo a troca do frio entre a Água e o Ar, o que tornaria então a Água quente e úmida e o Ar frio e úmido, para manter a coerência do sistema astrológico. ${ }^{15}$

Já Johannes Kepler, no início do século XVII, passa ao largo disso, vai além e questiona totalmente o sistema zodiacal deixado pela tradição, não reconhecendo inicialmente nenhuma razão para os signos serem coisas estanques, diferenciados

\footnotetext{
${ }^{14}$ The solid signs, Taurus, Leo, Scorpio, and Aquarius, are those which follow the solstitial and equinoctial signs; and they are so called because when the sun is in them the moisture, heat, dryness, and cold of the seasons that begin in the preceding signs touch us more firmly, not that the weather is naturally any more intemperate at that time, but that we are by then inured to them and for that reason are more sensible of their power.

${ }^{15}$ citado em Clefs pour l'astrologie, de Jacques Halbronn. Editions Seghers, Paris, 1976, p. 116-117.
} 
qualitativamente pelos Elementos, já que não há uma divisão assim justificável astronomicamente; a não ser no máximo aquela dada pelos Equinócios e Solstícios, ou seja, as estações do ano:

"Parece que esta antiga divisão do zodíaco em doze partes iguais se fundamenta antes de tudo numa arbitrariedade humana, e que os signos não estão em realidade ou por natureza tão precisamente separados entre si, nem que suas características, segundo se definem por estes limites, se justaponham... No que diz respeito ao ponto cardeal e ao primeiro ponto de Áries, isto é realmente algo natural."16

"Ainda que o sol, na medida em que avança pelos doze signos, muda as estações na terra de acordo com as quatro qualidades, isto não se produz nesta seqüência [que foi criada pelos astrólogos]... ${ }^{17}$

No entanto Kepler aceitava que o laço entre o Criador e a natureza era geométrico e

dividido em proporções harmônicas, conforme denota esta passagem:

"O laço mais forte mediante o qual este mundo inferior se conecta com o céu e se unifica com ele consiste em que todos os poderes se forjam de cima de acordo com o ensinamento de Aristóteles, a saber, que dentro deste mundo inferior se oculta uma natureza espiritual capaz de operar através da geometria, que se vitaliza através das relações geométricas e harmônicas, originando-se em uma urgência interior implantada pelo Criador, e que inspira e motiva a utilização de tais poderes." 18

\footnotetext{
${ }^{16}$ Parece que esta antigua división del zodíaco en doce partes iguales se funda ante todo en una arbitrariedad humana, y que los signos no están en realidad o por naturaleza tan precisamente separados entre sí, ni que sus características, según se definen por estos límites, se yuxtapongan... En lo que respecta al punto cardinal y al primer punto de Aries, esto es realmente algo natural.

(Informe sobre la Triplicidad de Fuego, 1603) Esta e as outras passagens foram traduzidas para o inglês por Kenneth G. Negus, EucopiaPublications, Princeton, Nueva Jersey, 1987, e estão no site http://cura.free.fr/docum/15kepes.html, em 30/11/2003.

${ }^{17}$ Aunque el sol, a medida que avanza por los doce signos, cambia las estaciones en la tierra de acuerdo con las cuatro cualidades, esto no se produce en esa secuencia [que fue creada por los astrólogos]... (Respuesta al Dr. Röslin, 1609)

${ }^{18}$ El lazo más fuerte mediante el cual este mundo inferior se conecta con el cielo y se unifica con él consiste en que todos los poderes se forjan desde arriba de acuerdo con la enseñanza de Aristóteles, a saber, que dentro de este mundo inferior se oculta una naturaleza espiritual capaz de operar a través de la geometría, que se vitaliza a través de las relaciones geométricas y armónicas, originándose en una urgencia interior implantada por el Creador, y que inspira y motiva la utilización de tales poderes. Tertius Interveniens, 1610.
} 
Kepler descrevia aí principalmente o reino mineral, cujas formas cristalinas básicas relacionou com as órbitas planetárias em seu sistema de mundo astronômico. Manteve uma dúvida se esta geometria poderia ser de fato aplicada às plantas e aos animais, ou seja, se havia uma geometria da vida tal qual aquela proposta para o zodíaco pelos astrólogos:

Em meu livro, recusei de fato o conceito de que a divisão do céu em doze signos e a distribuição destes entre os planetas [ou seja, como regentes] tiveram alguma base na natureza. Não obstante, como a raça humana concebeu esta partição desde a época dos caldeus até nossos tempos, e em todas as nações, ponho em consideração do leitor a possibilidade de que Deus mesmo se conforme a ela, ainda que tal divisão não seja natural, e de que Ele deseje falar aos seres humanos por este meio em uma linguagem ou com um método de comunicação que eles compreendam. ${ }^{19}$

De fato esta distribuição dos Elementos no Zodíaco tem uma origem obscura, mas revela-se ali a intenção de expressar um perfeito equilíbrio entre os Elementos, e Kepler pondera que Deus poderia aceitar isto.

Parece claro que a distribuição dos Elementos no Zodíaco é fruto de um desejo humano de expressar ali uma harmonia e uma geometria perfeitas, como o céu só poderia ser, daí os Elementos serem distribuídos - sincronicamente - em triângulos eqüiláteros, formando as chamadas Triplicidades. Possivelmente o Ar e não a Água foi colocada ali oposta ao Fogo devido à diferença parcial entre ambos que é a umidade que, aliás, tornase a única qualidade diferenciadora dos signos opostos no Zodíaco. Fogo e Ar compartilham o fato de serem "quentes", então os "opostos" no Zodíaco não podem ser

\footnotetext{
19 En mi libro, recusé en efecto el concepto de que las divisiones del cielo en doce signos y la distribución de éstos entre los planetas [es decir, como regentes] tuvieran alguna base en la naturaleza. No obstante, como la raza humana ha concebido esta partición desde la época de los caldeos hasta nuestros tiempos, y en todas las naciones, pongo a consideración del lector la posibilidad de que Dios mismo no se conforme a ella, aun cuando tal división no sea natural, y de que Él desee hablar a los seres humanos por este medio en un lenguaje o con un método de comunicación que ellos comprendan.

(On the Nova in the Foot of Ophiucus, 1606)
} 
totalmente diferentes, talvez porque se não fosse assim haveria a tendência a uma “desintegração" deste, já que Fogo e a Água têm tendências e movimentos opostos: um sobe, o outro desce. Também Ar e Terra têm tendências e os mesmos movimentos opostos, e se estivessem opostos no Zodíaco levariam à sua desintegração. Portanto Água e Terra são colocados como opostos no Zodíaco, compartilhando serem "frios" e se diferenciando também apenas pela umidade.

Com o Ar - quente e úmido - no meio do inverno oposto ao Fogo - quente e seco - no meio de verão, agora resta colocar Água e Terra respectivamente no meio do outono e no meio da primavera. Igualmente não aparece uma razão imediata para a Terra dominar o meio da primavera e não do outono, dado que aquela é a estação úmida. Novamente devemos pensar na idéia de que o Zodíaco expressa uma intenção de equilíbrio, para que o Céu possa exercer controle sobre a terra impondo mudanças com seu movimento. Assim Touro, um signo da Terra - seca e fria - está no meio da estação úmida, e Escorpião, um signo da Água - úmida e fria - está no meio da estação seca.

Assim, com os quatro signos Fixos tendo seus Elementos determinados, os outros ganham por conseqüência seus Elementos, devido à idéia dominante dos Triângulos dos Elementos no Zodíaco, ou as Triplicidades. Necessariamente haverá também um signo cardeal e um Mutável do mesmo Elemento daquele signo Fixo. Com isso podemos avançar um pouco mais na análise, e perceber o quanto a idéia da interação dos triângulos eqüiláteros dos Elementos no Zodíaco com os quadrados dos Ritmos é instigante e facilmente captura a imaginação, permitindo analogias entre o Céu e a natureza terrestre.

$\mathrm{Na}$ análise dos signos Cardeais, percebemos a mesma intenção de indução de equilíbrio na forma como são colocados. Sabemos que os signos cardeais são relacionados às quatro direções do espaço. Assim Norte se relacionava ao início do verão, dado que este começa quando o sol atinge sua declinação máxima para norte, no Trópico de Câncer. Já 
Sul se relacionava ao início do inverno, no Trópico de Capricórnio. De novo busca-se o poder integrador do Zodíaco, pois já que no planeta há mais terras ao norte e mais águas ao sul, esta atuação zodiacal traria mais Água ao norte e mais Terra ao sul: Água iniciando o verão e Terra iniciando o inverno. As analogias adequadas para o Fogo e o Ar são com o Leste e o Oeste, dado que no Leste o sol e outros planetas nascem, numa imagem do Fogo Cardeal relacionado a Carneiro, e no Oeste eles se põem, deixando o espaço para o Ar Cardeal de Balança.

Finalmente os signos Mutáveis ou Bicorpóreos, assim chamados porque fazem a passagem entre as estações, e “...compartilham, como tais, no fim e no começo, as propriedades naturais dos dois estados de clima"20: Gêmeos - do Ar - entre primavera e verão, Virgem - da Terra - entre este e o outono, Sagitário - do Fogo - entre este e o inverno, Peixes - da Água - entre este e a primavera.

É este zodíaco que integra opostos que se usa para determinar os temperamentos humanos, segundo a localização do Sol no momento do nascimento. Estes temperamentos levariam a qualidades psicológicas diferenciadas: "Palavras-chave: fogo: entusiasta; terra, prático, estável; ar, intelectual, comunicativo; água, emocional, intuitivo.”, segundo um manual astrológico de 1982 (PARKER, PARKER, 1982, p. 104). Outro manual astrológico contemporâneo afirma:

\footnotetext{
20 "The bicorporeal signs, Gemini, Virgo, Sagittarius, and Pisces, are those which follow the solid signs, and are so called because they are between the solid and the solstitial and equinoctial signs and share, as it were, at end and beginning, the natural properties of the two states of weather." Tetrabiblos, Livro 2, 11.
} 
“... os signos do ar vivem no reino abstrato do pensamento, e para eles um pensamento é simplesmente tão real (ou, de fato, mais real, conforme é evidenciado pelo comportamento deles) quanto qualquer objeto material. Os signos de água vivem em seus sentimentos e, mais do que qualquer outra coisa, o estado emocional deles é o que determina o seu comportamento. Os signos do fogo vivem num estado de atividade inspirada, altamente excitada, e a conservação desse estado de ser é decisiva para a manutenção da saúde e da felicidade dos signos de fogo. Os signos da terra estão assentados no mundo material. O mundo material e as suas preocupações com a sobrevivência e com a produção são considerados muito mais reais do que qualquer outro aspecto da vida" (ARROYO, 1986, p. 113).

Apresentamos em seguida a Figura 2, que expressa estas relações entre Elementos e

Ritmos descritas anteriormente:

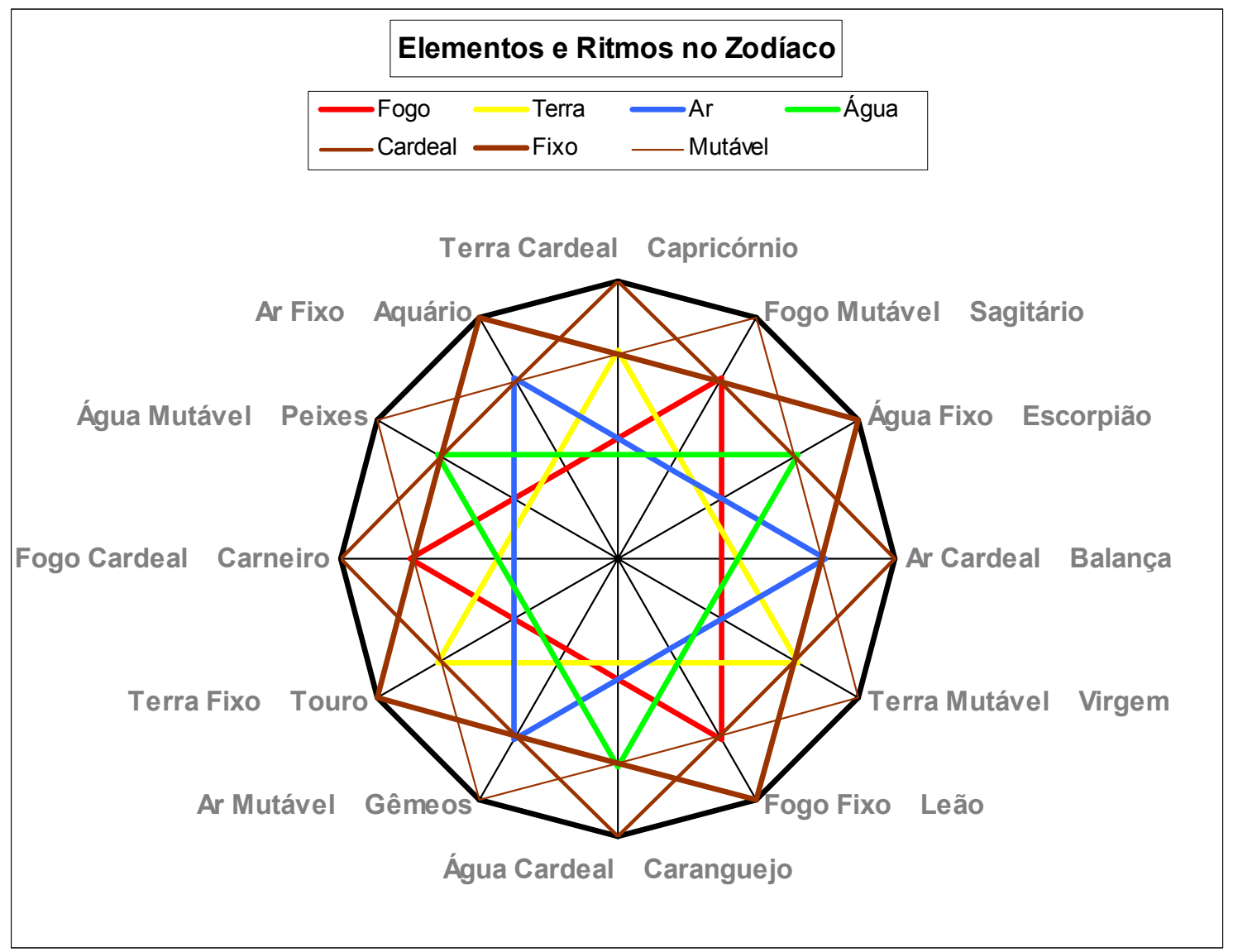

Figura 2: Triplicidades e Quadruplicidades no Zodíaco 
Apresentamos em seguida na Figura 3 a relação entre Elementos, Ritmos e as fases das estações do ano para o Hemisfério Norte, que são relacionadas aos signos segundo o Zodíaco Matemático, também chamado Tropical. Este Zodíaco é estritamente relacionado com os Equinócios e Solstícios, portanto as datas dos inícios dos signos Cardeais podem variar em torno de alguns dias de ano para ano, acompanhando os inícios das estações do ano. Em geral se adotam datas médias para isto, e estas são assumidas pelos textos astrológicos para definir os períodos dos signos.

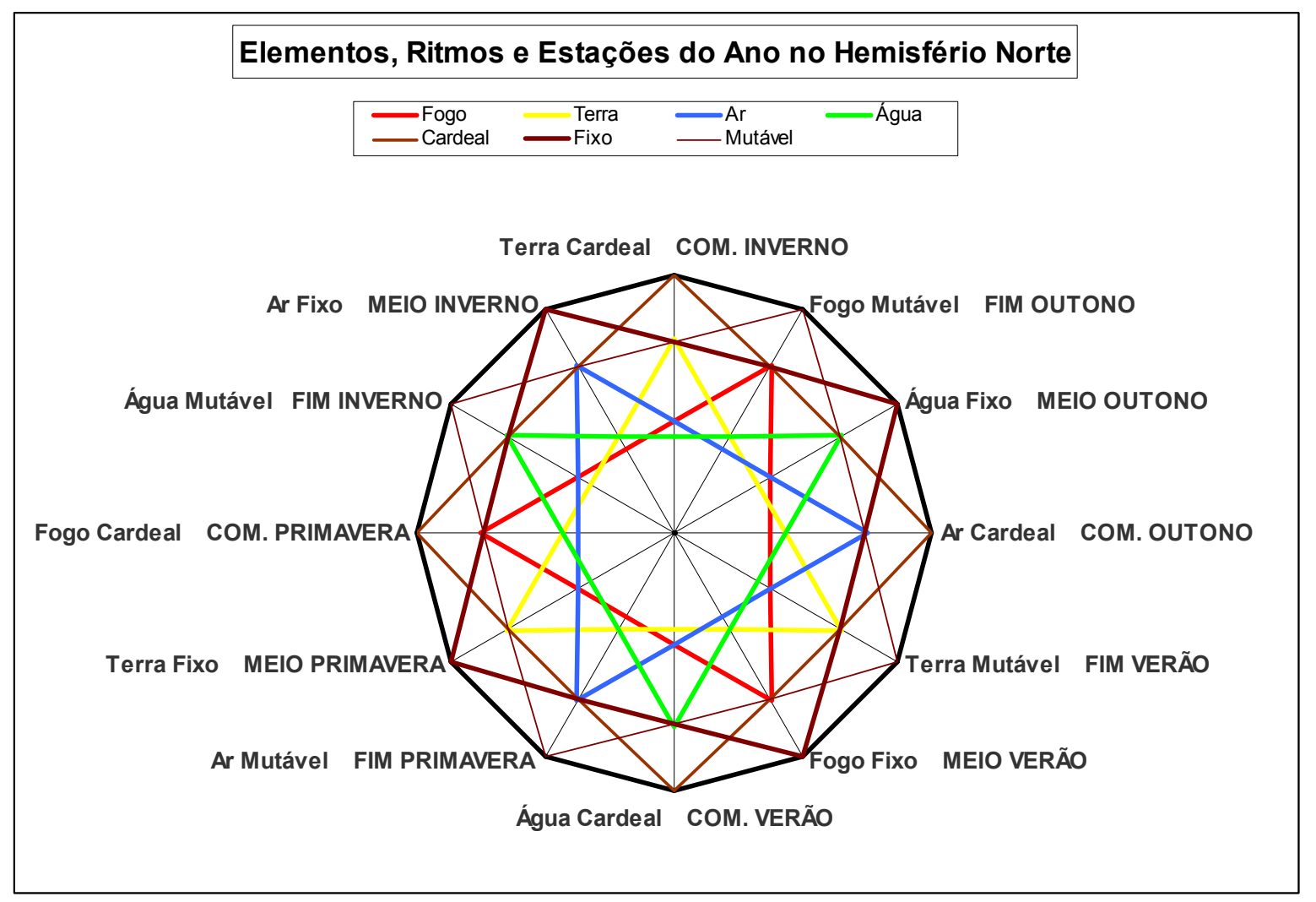

Figura 3: Elementos e fases das estações do ano

Já no Hemisfério Sul as estações do ano são diametralmente opostas às que estão ocorrendo no Norte, ainda que comecem nos mesmos dias: astronomicamente, 20 de Março para o Outono, 21 de Junho para o Inverno, 23 de Setembro para a Primavera e 22 de Dezembro para o Verão. 
Apresentamos em seguida na Figura 4 as relações entre Elementos, Ritmos e as fases das estações do ano conforme ocorre no Hemisfério Sul, portanto conforme ocorria nos nascimentos das pessoas de nossa amostra.

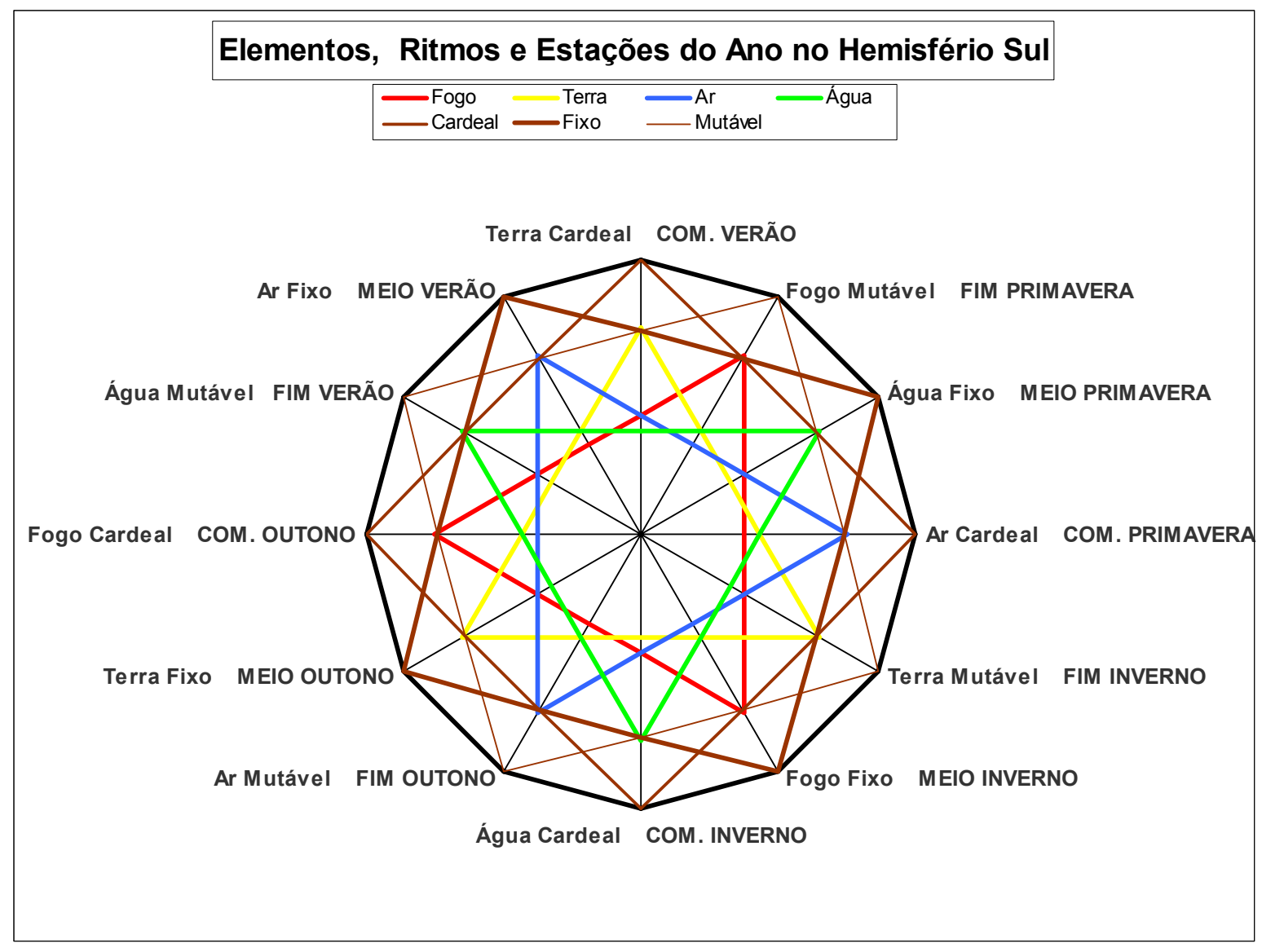

Figura 4: Elementos e estações do ano no Hemisfério Sul

A idéia básica da astrologia chamada "natal" é que a alma, ao descer do céu para animar um corpo, traria as qualidades dadas por aquele signo onde o sol se encontrava, daí a predição de alguém ser “do" Fogo, ou Ar, ou "da” Água ou Terra, predominantemente em seu caráter. Há uma divisão tradicional em dois grupos: “...sendo o fogo e o ar considerados ativos e auto-expressivos e a água e a terra considerados passivos, receptivos e auto-repressivos" (ARROYO, 1986, p. 106). Esta divisão relembra a divisão básica entre extroversão e introversão, podendo então ser testada pela psicologia. 


\subsection{TESTANDO OS SIGNOS, OS ELEMENTOS E AS DIMENSÕES DE PERSONALIDADE}

O psicólogo Hans Eysenck, um dos grandes nomes da pesquisa das bases biológicas da personalidade, iniciou uma série de pesquisas empíricas sobre diferenças de personalidade segundo os Elementos dos signos solares, junto com o também psicólogo O. White e o astrólogo Jeff Mayo, com o teste que criou a partir de uma teoria fatorial de personalidade: EPI - Eysenck Personality Inventory ${ }^{21}$. A ponte com a astrologia vem desde a Medicina astrológica de Galeno (séc. II d. C.), com quatro tipos de "temperamentos" em função da predominância de um dos "humores" ligados aos quatro Elementos: Fogo = Colérico, Terra $=$ Melancólico, $\mathrm{Ar}=$ Sanguíneo, e Água $=$ Fleumático. Há uma divisão em dois grupos que tem justificativa astrológica, conforme a expressou um astrólogo contemporâneo:

“... os signos da água e da terra são mais auto-repressivos do que os signos do ar e do fogo, no sentido de que eles vivem mais dentro de si mesmos e não se permitem projetar exteriormente a sua energia essencial sem antes usar uma boa dose de cautela e ponderação. Os signos do fogo e do ar são mais autoexpressivos porque estão sempre 'deixando sair', derramando, sem reservas, as suas energias e a sua substância vital; os signos do fogo por meio da ação direta e os signos do ar por meio da interação social e da expressão verbal" (ARROYO, 1986, p. 106-107)

A partir destas proposições tradicionais, Eysenck, White e Mayo unificaram Fogo e Ar como sendo Elementos Positivos ${ }^{22}$ que levariam à Extroversão em função do caráter de

\footnotetext{
${ }^{21}$ um questionário de autodescrição que avalia extroversão e neuroticismo.

${ }^{22}$ Há uma tradição astrológica de se agrupar signos de Fogo e Ar como Masculinos (Ptolomeu) ou Positivos, e os de Terra e Água como Femininos ou Negativos. Tanto por coerência com as Qualidades que originam os Elementos, quanto por buscar evitar conotações de valor, vamos doravante denominá-los respectivamente como Quentes e Frios.
} 
quente que compartilham; e Terra e Água como sendo Negativos, que levariam à Introversão em função do caráter de frio que compartilham (EYSENCK, 1973).

Assim, como o Zodíaco inicia em Carneiro, que é do Fogo, temos que pela alternância dos Elementos todos os signos ímpares serão Positivos, e todos os pares serão Negativos. Testaram a predição da teoria astrológica que é mostrada na Figura 5 - com os seis signos ímpares acima da média (extrovertidos) e os seis pares abaixo (introvertidos) formando um padrão "dente-de-serra".

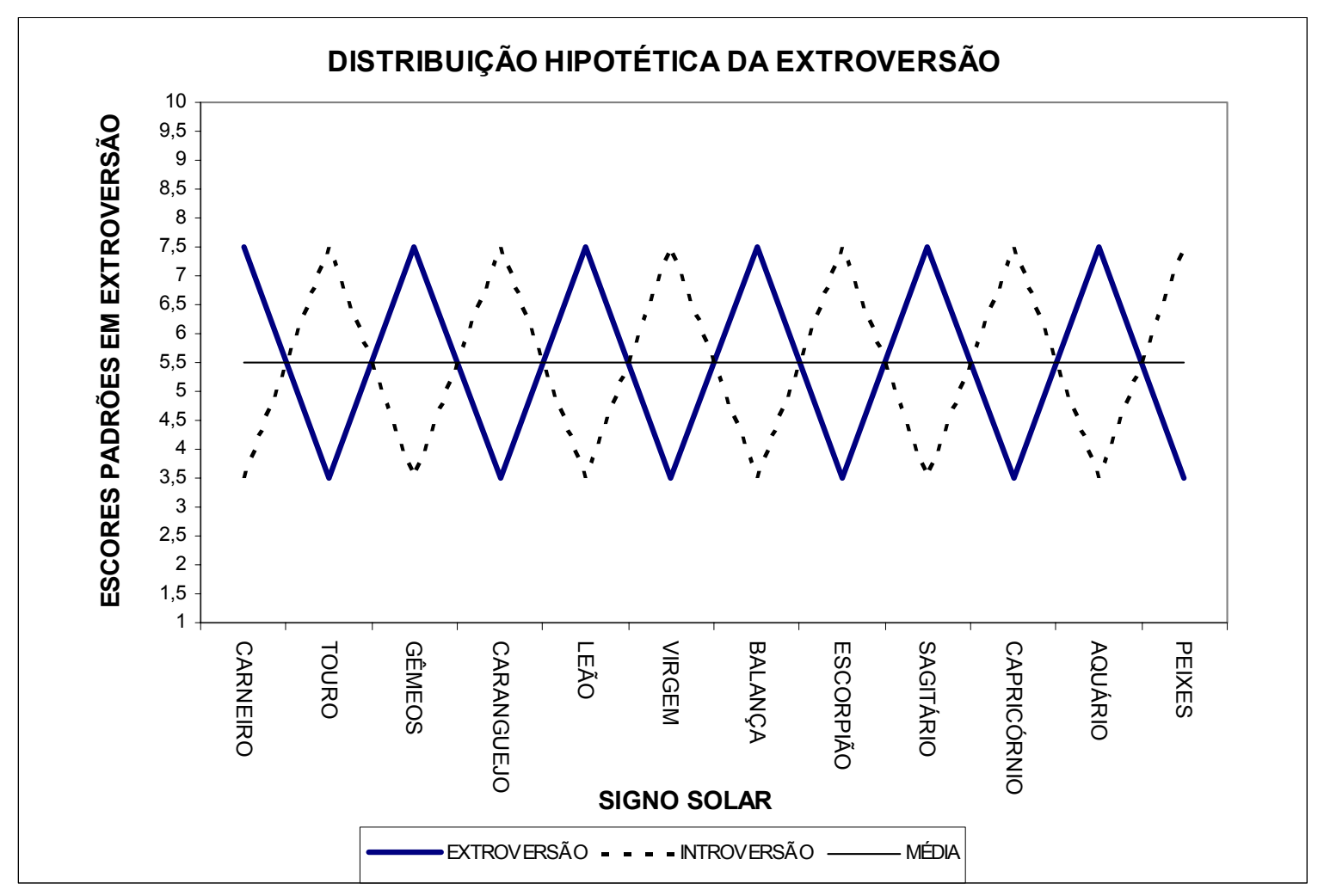

Figura 5: O padrão “dente-de-serra”

Mayo, White, e Eysenck encontraram, numa amostra de 2324 sujeitos, uma variação significativa $(\mathrm{p}=0,0001)$ com o padrão dente-de-serra para a Extroversão conforme a predição astrológica (Fogo e Ar = extroversão acima da média, Terra e Água = extroversão abaixo da média) (1978). 
Isto foi replicado e confirmado tanto no Hemisfério Norte (SMITHERS, COOPER, 1978; ROOIJ, BRAK, COMMANDEUR, 1988) quanto no Sul (JACKSON, 1979). Mas como outros estudos não confirmaram esta variação, tanto no Hemisfério Norte (JACKSON，FIEBERT，1980; RUSSELL，WAGSTAFF，1983; SHAUGHNESSY, NEELY, MANZ, NYSTUL, 1990) quanto no Sul (TYSON, 1977; VENO, PAMMENT, 1979), decidimos replicar a pesquisa, para medirmos o que ocorreria entre brasileiros. Em nossa Dissertação intitulada Astrologia, Meio-Ambiente e Personalidade: Um estudo empírico (RODRIGUES, 1997), comparamos os signos solares utilizando as escalas de personalidade medidas no 16 PF (Questionário dos 16 Fatores de Personalidade, de Raymond Cattell) - em sujeitos nascidos no Brasil.

Nos resultados da Dissertação apareceram para a Extroversão diferenças apenas marginalmente significativas para a hipótese astrológica usando a análise da variância (ANOVA), $[\mathrm{F}(1,273)=3,0467, \mathrm{p}=0,08]$, numa amostra de 275 brasileiros de ambos os sexos com a média de idade de 28 anos e 3 meses. Então, em parte das pesquisas, porque ocorreram os resultados aparentemente confirmadores da predição astrológica?

Houve uma nova hipótese, advinda da "teoria da atribuição", que foi proposta e abriu um novo ramo de pesquisas: a hipótese que as respostas nos questionários foram influenciadas pela auto-atribuição (BEM, 1972) de características astrológicas, ou seja, as pessoas responderam os questionários em função das características descritas pela astrologia para os seus signos que acreditam terem, e não em função de verdadeiro autoconhecimento.

A teoria da atribuição de causalidade foi proposta por Fritz Heider em 1958 para compreender como as pessoas em geral explicam em suas vidas cotidianas as causas dos comportamentos dos outros, e mesmo os próprios. Heider afirma que: 
“...o homem deseja conhecer as fontes de suas experiências, saber de onde vêm, saber como surgem, não apenas por curiosidade intelectual, mas também porque essa atribuição lhe permite compreender o seu mundo e predizer e controlar acontecimentos referentes a ele e aos outros" (1970, p. 169)

Como um dos desenvolvimentos da teoria da atribuição, a teoria da autoatribuição foi proposta por Daryl Bem para explicar a atribuição de "propriedades disposicionais" ao ator pelo próprio sujeito, ou seja “...a explicação causal de atitudes, emoções, sentimentos, e outros estados internos", dada pela própria pessoa (DELA COLETA, 1982, p. 40). Neste caso está se estudando mais do que as causas dos acontecimentos ou a origem destes, mas que tipos de inferências se fazem sobre o que "vai por dentro" da própria pessoa em função de seus comportamentos manifestos. Há três postulados básicos da teoria:

1) "tanto o ator quanto o observador envolvidos em um fenômeno qualquer usam os mesmos processos de inferência para chegar às características disposicionais capazes de explicar aquele dado efeito." (DELA COLETA, 1982, p. 42).

2) “... indivíduos chegam a conhecer suas atitudes, emoções e outros estados internos, parcialmente os inferindo das observações de seu próprio comportamento aberto e/ou de circunstâncias nas quais este comportamento ocorre.” (BEM, 1972, p. 2).

3) “... na medida em que os fatores externos são fracos, ambíguos, ou não interpretáveis, o indivíduo está funcionalmente na mesma posição que um observador externo, um observador que deve necessariamente se basear nesses mesmos fatores externos para inferir os estados internos do indivíduo.” (BEM, 1972, p. 2).

Em decorrência destes postulados da teoria da auto-atribuição, deduziu-se que, ao se manipular informações externas sobre os próprios sujeitos através de falsos feedbacks, poder-se-ia modificar a auto-atribuição, fazendo os sujeitos acreditarem que são possuidores daquelas características, que apresentam certas atitudes ou estão de fato 
naqueles estados. E isto foi o encontrado em experimentos. Em alguns deles manipulou-se a auto-atribuição de estados de medo ou de estimulação em função de um falso feedback dos batimentos cardíacos, levando a pessoa, ao ouvi-los, a acreditar que estivesse com menos medo (em freqüência cardíaca mais lenta) ou gostando mais de algo (em freqüência cardíaca aumentada). Também se utilizou um falso feedback para insones, no clássico experimento de Storms e Nisbett (1970), fazendo com que sujeitos que ingeriram um placebo como se fosse um estimulante acreditassem que seu estado excitado fosse devido à pílula e não a eles mesmos, e assim dormissem mais rapidamente; enquanto que os sujeitos a quem foi dito que o placebo era relaxante, ao se perceberem tensos, atribuíram a si mesmos a causa da insônia e pioraram (DELA COLETA, 1982, p. 46). Estes experimentos demonstram que: a) de fato as pessoas procuram observar seus comportamentos para poderem atribuir a elas mesmas estados, atitudes ou disposições. b) a auto-atribuição de atitudes e disposições a partir de comportamentos faz com que estas se estabeleçam de fato na pessoa. E isto pode ter como conseqüência a repetição dos mesmos comportamentos.

Assim, a astrologia, ao descrever como as pessoas são conforme os seus signos solares, fornece as "características disposicionais" prontas para os que acreditam em suas descrições dos signos, fazendo com que as pessoas possam compreender de maneira aceitável ou até justificável porque agiram ou agem de determinadas maneiras. Haveria uma determinação "astral", advinda das qualidades que sua alma adquiriu ao vir do céu para a terra. No Anexo I temos as descrições dos signos por "traços", "positivos" ou "negativos" conforme sua desejabilidade moral; pode-se observar ali uma aparente diversidade de traços dentro de cada signo, mas esta é justificada astrologicamente, em função da fusão das imagens do signo, de seu Elemento e, mais ainda, da influência de seu "Planeta Regente". Fica difícil discriminar se é a própria imagem do signo que determina mais sua "personalidade", ou se o Elemento ou seu Planeta, o qual também tem a 
"personalidade" do deus ou deusa que lhe dá nome. Na teoria astrológica os três fatores se unem para compor coerentemente uma imagem convincente de uma personalidade, certamente a partir da imagem do signo. $\mathrm{O}$ que pode ser imaginado vivamente por quem leia a descrição dos signos. Isto certamente vai revelar-se nas respostas que os sujeitos que acreditam em astrologia darão a questionários de autodescrição, já que nestes casos responderão sobre seus interesses, atitudes e comportamentos observados.

Publicou-se, no artigo de Mayo, White e Eysenck a demanda por pesquisas replicadoras nas quais o conhecimento da astrologia dos sujeitos testados fosse uma variável controlada (1978). Em resposta, a hipótese da auto-atribuição de características astrológicas como variável interveniente na autodescrição foi testada e comprovada numa pesquisa. Pawlik e Buse aplicaram uma versão do EPI em 799 sujeitos na Alemanha, junto com outro questionário que mediu sua familiaridade com a astrologia. Conforme as respostas ao segundo questionário os sujeitos foram divididos em "não crentes", "crentes" e "fortemente crentes", grupos com tamanhos próximos. Não houve padrão astrológico reconhecível entre os "não crentes", mas houve a replicação dos resultados de Mayo, White e Eysenck entre os dois grupos de crentes (PAWLIK, BUSE, 1979). Confirmou-se então o efeito da auto-atribuição.

Mas, até que ponto a sugestão dada pela declaração do objetivo da pesquisa pode ter influenciado os resultados?

Para controlar melhor o efeito da auto-atribuição e separá-lo de efeito da sugestão, foi delineada uma pesquisa comparando grupos que sabiam com grupos que não sabiam dos objetivos da pesquisa (ROOIJ, 1994). Nela juntaram-se dois estudos, com 500 pessoas no total, 305 homens e 195 mulheres, com idades de 16 a 68 anos. Foi usado o ABV Amsterdamse Biografische Vragenlijst, que é derivado do EPI, para medir a Extroversão. Cada grupo foi dividido entre aqueles a quem foi dito que seus testes eram para uma 
"pesquisa sobre características de personalidade", e outros a quem foi dito que era uma "pesquisa sobre astrologia", como sugestão (cue) para induzir mais no segundo grupo as respostas segundo a crença ou não na astrologia. Também foi investigado posteriormente se as pessoas tinham crença e conhecimento em astrologia, sendo este conhecimento constituído na descrição de três características de seu Signo Solar. Os sujeitos foram então divididos entre "conhecedores", caso soubessem seus signos e descrevessem três características de personalidade correspondentes; e "não conhecedores" de astrologia, caso não descrevessem características, mesmo sabendo quais eram seus signos (ROOIJ, 1994).

Na pesquisa de Rooij e colaboradores, entre os “conhecedores" apareceu o padrão dente-de-serra, $(\mathrm{p}<0,0001)$. Já entre os "não conhecedores" houve o resultado que pode ser entendido como inverso, um padrão dente-de-serra ao contrário do postulado pela astrologia, como se pode ver no Gráfico I. Segundo os autores, nos resultados acima comentados, sugere-se que a auto-atribuição (por crença na descrição astrológica de seu signo) influencia o autoconceito. Assim sendo, os "conhecedores" de astrologia mostraram resultados mais definidos conforme a hipótese astrológica, do que os "não-conhecedores". A sugestão "astrologia" também teve mais efeito no grupo dos "conhecedores" do que no grupo dos "não-conhecedores". Então "as pessoas atribuem a si mesmas aqueles traços que pertencem a seu signo solar."23

Segundo os realizadores das pesquisas, as respostas dadas nos questionários puderam ser condicionadas pelo "processo de auto-observação seletiva" 24 , onde o sujeito focaliza conscientemente apenas os momentos em que agiu conforme o autoconceito astrológico, confirmando o que foi auto-atribuído.

\footnotetext{
23 "People attribute to themselves those traits that belong to their sunsign.", p. 987.

24 "processs of selective self-observation", p. 987.
} 


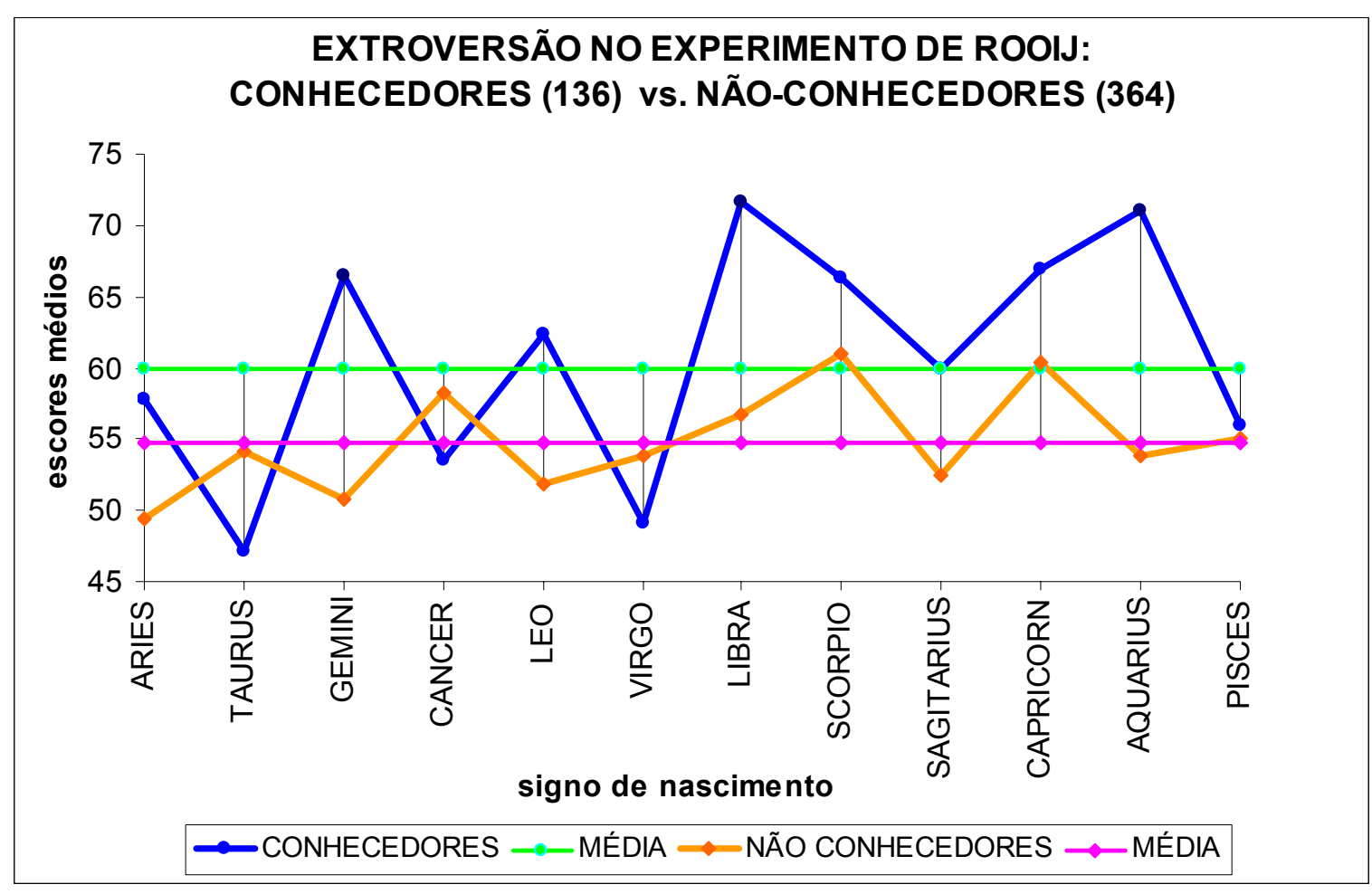

GRÁFICO I

Assim, não haveria necessariamente diferenças reais de comportamento entre as pessoas dos signos ímpares e pares. Pode ser apenas o caso de uma autodescrição equivocada, mais uma faceta do auto-engano (self-deception) (KELLY, 1998).

Em continuidade a esta linha de pesquisa, em 1995 Margaret Hamilton pesquisou a incorporação da informação astrológica no autoconceito. Pediu aos sujeitos que escolhessem, entre "pacotes" de traços astrológicos advindos dos signos (sem que fosse dito a origem desses traços), qual a melhor descrição de seu caráter. Teve o resultado de que os sujeitos que conheciam astrologia escolheram a descrição do próprio signo solar, de maneira significativamente diferente daquela dos sujeitos declarados não conhecedores da astrologia. A autora concluiu que "a exposição a descrições de personalidade baseadas astrologicamente pode afetar o autoconceito duradouro". ${ }^{25}$

\footnotetext{
25 "that exposure to astrologically based personality descriptions can affect long-term self-concept."
} 
Refinando a pesquisa sobre o processo de auto-atribuição de características astrológicas, Rooij replicou em 1999 esta pesquisa, desta vez correlacionou traços astrológicos separados, retirados também de manuais astrológicos, com o autoconceito de 422 pessoas, sendo selecionados oito traços para cada signo, quatro com conotações positivas e quatro com conotações negativas. Os sujeitos foram instruídos a classificar os 96 traços numa escala de cinco pontos indo desde " 1 = (não se aplica a mim)" até "5 = (aplica-se completamente a mim)". Os resultados demonstraram que para os sujeitos que conheciam astrologia (134) a escolha dos traços selecionados dos manuais era muito mais freqüente para traços do próprio signo (obtido posteriormente pelo pedido da data de nascimento) do que a escolha de traços de outros signos, mesmo sem ter sido dito para as pessoas qual a origem da listagem dos traços. O mesmo já não ocorreu para os sujeitos que não conheciam astrologia. A medida do conhecimento astrológico foi a mesma do experimento de 1993, a descrição de três características do signo solar. Rooij concluiu que a pesquisa também sugeriu que a exposição à informação astrológica afeta de modo duradouro o autoconceito, para aqueles sujeitos que têm conhecimento astrológico (ROOIJ, 1999).

Numa análise superficial a questão parecia encerrada, dado que a variação astrológica nas médias de extroversão poderia ser meramente resultado da influência no autoconceito da crença na astrologia e suas descrições de signos, e deste na autodescrição conforme avaliada pelo questionário (KELLY, DEAN, SAKLOFSKE, 1990).

Permanece, no entanto, uma pergunta: Ao responderem um teste de personalidade as pessoas que conhecem astrologia tendem a se descrever como possuidores de atitudes e comportamentos "típicos" de seus signos solares exclusivamente por acreditarem e observarem seletivamente seus comportamentos? Ou suas respostas ao teste correspondem 
a suas atitudes e comportamentos realmente mais freqüentes, e estes estão de alguma maneira relacionados às suas datas de nascimento?

Sabemos que a auto-atribuição poderia ser mediadora entre o autoconceito e o comportamento:

“... ao se fazer atribuição ao comportamento emitido pelo próprio sujeito ou por outros, a atribuição seguiria à ação, mas esta mesma atribuição teria significativa influência sobre os outros comportamentos que viessem a ser emitidos, e que então já compreenderiam, de um modo ou de outro, a possível explicação causal para os eventos que o antecederam” (DELA COLETA, 1982, p. 47).

Rooij termina seu artigo de 1999 afirmando que seria interessante investigar se o conhecimento em astrologia não afeta apenas o autoconceito, mas também o comportamento real da pessoa. ${ }^{26}$

Nesta Tese damos um passo nesta direção, apoiados por um dos resultados da Dissertação: ao avaliarmos se qualquer uma das 16 escalas do 16 PF variava conforme predições da teoria astrológica relativas aos signos, e não só a Extroversão, descobrimos que a escala de Inteligência, entendida ali como Habilidade Geral Cristalizada, variou significativamente em conformidade com os signos subdivididos segundo os Elementos aos quais pertencem: todos os ímpares abaixo da média, maioria dos pares acima da média, conforme visto no Gráfico II. Aqui tivemos uma correlação positiva com um desempenho efetivo em 13 itens de raciocínio lógico (RODRIGUES, 1997).

\footnotetext{
26 "It would be interesting to investigate whether this knowledge may not only affect a person's self-concept, but also actual behavior"
} 


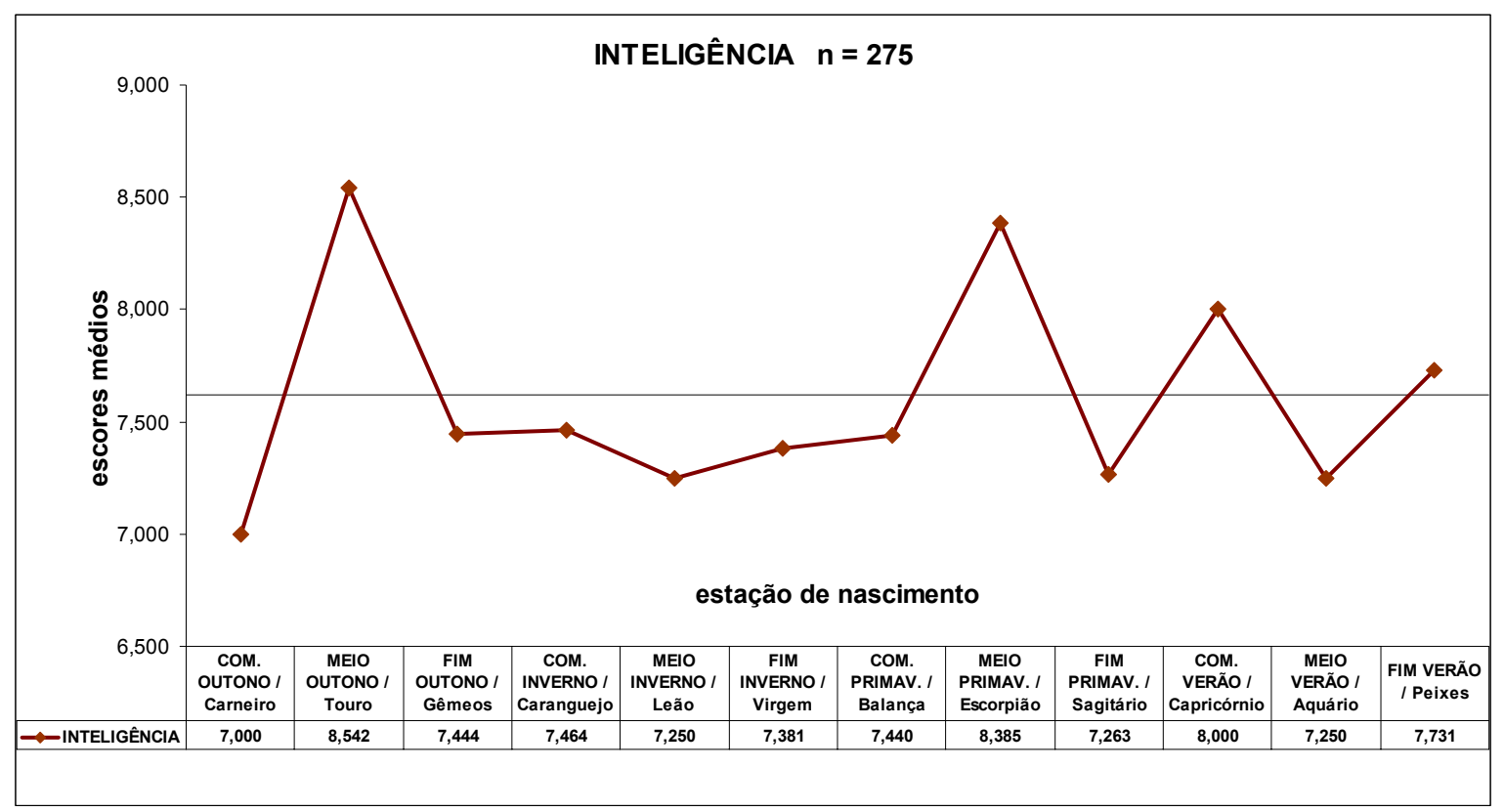

GRÁFICO II

Fruto indireto da auto-atribuição?

Se a auto-atribuição pode se estender ao desempenho, então temos algo importante em termos práticos: as pessoas desempenhariam de fato na vida em função de suas crenças sobre suas características, portanto o efeito da auto-atribuição ultrapassaria o autoconceito e afetaria o comportamento diante de desafios.

E mais: não haveria uma diferença de origem astrológica independente do conhecimento das pessoas e que se expressou na habilidade geral? A pergunta é cabível, mais ainda devido ao fato de que na pesquisa de Rooij e alunos, continuando com as conclusões, os autores observaram que: 
a) há mais extrovertidos entre os conhecedores da astrologia, o que fora encontrado também por outros pesquisadores (SHAUGHNESSY, NEELY, MANZ, NYSTUL, 1990). De fato podemos observar pelo Gráfico I que os que conhecem astrologia têm a média de extroversão mais alta $(F=8,09, p<0,005)$ do que os que não conhecem, mesmo que alguns subgrupos de signos pares tenham médias mais baixas do que aquelas dos que não conhecem astrologia ${ }^{27}$. Assim, ser mais extrovertido provavelmente se relacionaria a crer mais em astrologia;

b) a diferença (discrepância) nos resultados de extroversão entre o grupo dos que conhecem e o dos que não conhecem astrologia é maior entre os subgrupos ímpares (Positivos: teoricamente extrovertidos segundo os signos por pertencerem aos Elementos Fogo e Ar), do que entre os subgrupos pares (Negativos: teoricamente introvertidos segundo os signos por pertencerem aos Elementos Terra e Água), “...o que não invalida totalmente a teoria astrológica." (ROOIJ, 1994, p. 987). Ao menos no tocante a algum tipo de diferença entre estes dois grupos (signos ímpares e signos pares).

Os autores concluem que as pessoas nascidas naqueles períodos dos signos ímpares não são necessariamente mais extrovertidas, porém “...mais suscetíveis à informação vinda de fora sobre suas personalidades. ${ }^{28}$ (1994, p. 987).

Portanto, ou há algo anterior à auto-atribuição nos resultados que diferenciam personalidades segundo períodos de nascimentos correspondentes aos signos, ou a autoatribuição chega a ter um efeito formador na personalidade e no comportamento, de modo que a auto-observação mesmo que intencionalmente seletiva inclua algo não simplesmente auto-atribuído, selecionando aquilo que de fato é mais freqüente em seu comportamento, para responder o questionário (BEM, 1972).

\footnotetext{
${ }^{27}$ Isto se deve provavelmente à pequena quantidade de sujeitos nestes subgrupos.

28 "...more susceptible to information about their personality from outside."
} 
Será então que foi esta mesma diferença a que inferimos na Dissertação, através dos resultados de Inteligência (RODRIGUES, 1997)? Lembremos novamente que os 13 itens de raciocínio lógico no 16 PF medem uma capacidade efetiva de solução de problemas, algo longe do autoconceito, já que aqueles problemas lógicos foram delineados para medir a habilidade geral da pessoa, advinda da aprendizagem.

A inclusão destes itens de raciocínio no $16 \mathrm{PF}$, delineado para ser um teste de personalidade de origem fatorial, justifica-se por se entender que “... o estilo cognitivo atua como moderador na expressão de muitos traços de personalidade" (RUSSELL, KAROL, 1999, p. 44). O "estilo cognitivo" é um constructo teórico que expressa uma interação entre a inteligência e personalidade, ficando assim entre a habilidade e a estratégia usada para abordar as tarefas. Em nosso caso, interessa-nos o estilo como moderador da expressão da inteligência. $O$ estilo define a maneira como a pessoa vai usar sua inteligência (GRIGORENKO, STERNBERG, 1995, p. 205-206).

Entende-se, no entanto, que ainda que o 16 PF não permita uma medida totalmente confiável da habilidade mental (com apenas 13 itens), os “... resultados altos freqüentemente refletem maior habilidade de raciocínio porque as chances de se escolher a resposta correta por acaso são pequenas" (RUSSELL, KAROL, 1999, p. 44).

Mas o mais confiável e importante para a nossa pesquisa é que os resultados baixos em Inteligência:

“...estão propensos a ocorrer em examinandos com vida escolar deficiente ou que estejam deprimidos, ansiosos ou preocupados com seus problemas. Eles também ocorrem quando os examinandos são distraídos por estímulos externos, interpretam incorretamente as instruções ou, por razões diversas, não estão motivados a gastar seu tempo pensando nas respostas corretas" (CATTELL, H. B., 1989, p. 32). 29

\footnotetext{
${ }^{29}$ citado em RUSSELL, M. T., KAROL, D. L.: 16PF, quinta edição: manual. CEPA, Rio de Janeiro, 1999, p. 44.
} 
O uso do 16 PF permite então, a mais do que outros testes de personalidade, que os resultados desses 13 itens de raciocínio possam ser correlacionados com os resultados dos 15 outros fatores do teste, dado que os itens são aplicados conjuntamente. Assim podemos perceber se há uma combinação certa de fatores de personalidade que levariam àqueles melhores resultados nos itens de Inteligência para os signos pares, ou se há, ainda, uma outra combinação de fatores que tenha levado a resultados grupais baixos para os signos ímpares. Por isso resolvemos usá-lo novamente na pesquisa desta Tese, em busca de começar a ultrapassar o limite do autoconceito.

Esta provável distribuição pode, ainda, ser conseqüência ou da crença nas próprias capacidades que as descrições dos signos podem oferecer, ou de uma real diferença entre as personalidades agrupadas sob os signos ímpares e pares. Diferença esta que levaria a melhores resultados de Inteligência entre os segundos, independentemente de que os nascidos naqueles períodos acreditem ou não nas descrições de seus signos astrológicos.

O que torna a questão mais complexa é que não é prevista na teoria astrológica esta distribuição alternada da capacidade de resolver problemas lógicos, em “dente-de-serra", muito menos como acima da média para os signos pares conforme pode ser visto no Gráfico II. Ou seja, os signos dos Elementos Terra e Água não são descritos na astrologia como mais inteligentes, mas antes ao contrário os signos do Elemento Ar, que são ímpares. No entanto surpreendentemente Inteligência foi o fator com variação mais significativa segundo a alternância par - ímpar em toda a Dissertação, como se lê nas Tabela 1 e 2 (RODRIGUES, 1997).

Tabela 1: INTELIGÊNCIA

RESUMO

\begin{tabular}{|l|l|l|l|l|}
\hline Grupo & Contagem & Soma & Média & Variância \\
\hline SIGNOS ímpares & 125 & 905 & 7,240 & 3,813 \\
\hline SIGNOS pares & 150 & 1186 & 7,907 & 4,139 \\
\hline
\end{tabular}


Tabela 2: ANOVA

\begin{tabular}{|l|l|l|l|l|l|l|}
\hline Fonte da variação & $S Q$ & $G l$ & $M Q$ & $F$ & Valor $\boldsymbol{P}$ & F crítico \\
\hline Entre grupos & 30,303 & 1 & 30,303 & 7,593 & $\mathbf{0 , 0 0 6}$ & 3,876 \\
\hline Dentro dos grupos & 1089,493 & 273 & 3,991 & & & \\
\hline$\Sigma$ & 1119,796 & 274 & & & & \\
\hline
\end{tabular}

O resultado não foi mais significativo porque o padrão dente-de-serra foi quebrado no inverno - os três signos correspondentes ao inverno estão abaixo da média geral. É necessário comentar aqui que este dado leva a supor uma certa influência sazonal que fora encontrada também em pesquisa na Índia (KANEKAR, MUKERJEE, 1972), na qual os nascidos no verão tiveram melhor desempenho nas Matrizes Progressivas de Raven do que os nascidos no inverno. Parece haver um leve fator restritivo para a inteligência nos nascidos no pleno inverno, pode ser devido a déficit nutricional e / ou menor estimulação ambiental para o desenvolvimento das habilidades. Assim em nosso caso as médias daqueles grupos do começo e do fim do inverno - que seriam acima da média para manter a coerência com o grupo dos signos pares - ficaram abaixo da média geral, acompanhando o grupo do meio do inverno no qual há uma somatória da tendência astrológica com a sazonal. Ao analisarmos o Gráfico II, percebe-se o padrão dente-de-serra, mas sendo como “comprimido" no inverno.

Com esta abordagem surgem então duas vertentes de exploração dos dados, uma relativa a um padrão de variação dependente do conhecimento da pessoa sobre seu próprio signo e crenças nestas afirmações, e outra relativa a uma possível variação independente da crença, esta capturável diretamente pelos resultados de Inteligência já que ali se mede um comportamento de solução de problemas lógicos, e não apenas o autoconceito como fruto de auto-atribuição. 
O que é interessante quanto à astrologia é que as pessoas que acreditam na destinação de características pelo signo do nascimento acreditam que estas características são congênitas (recebidas de fora, mas internalizadas ao nascer) e estáveis tanto em si mesmos quanto em outros (WEINER, 1972). Assim, estas características podem ser compreendidas pela própria pessoa como capacidades, sendo mais do que simples tendências de personalidade, ou, mais ainda, como necessariamente relacionadas a certas capacidades mentais. (ver Anexo I).

No caso dos conhecedores da astrologia, haveria uma auto-atribuição de capacidade, mais do que de atitude ou de personalidade, levando a um comportamento coerente com a crença?

Para abordar esta auto-atribuição de capacidade que acaba por se transformar numa certeza para a pessoa, precisaríamos ir além da auto-atribuição e recorrer ao conceito de Auto-eficácia ${ }^{30}$, proposto desde 1977 por Albert Bandura: a crença na própria capacidade de comportar-se de uma determinada maneira. A pessoa se transforma naquilo que lhe é dito que ela é e faz aquilo que lhe dizem que é capaz de fazer, se de algum modo é levada a acreditar nisso. Vamos enveredar inicialmente na primeira vertente: Da auto-atribuição ao possível aumento das próprias capacidades.

\footnotetext{
30 "Perceived self-efficacy is defined as peoples's judgements of their capabilities to organize and execute courses of action required to attain designated types of performances. It is concerned not with te skills one has but with judgements of what one can do with whatever skills one possesses.” (Bandura, 1986, p.391)
} 


\section{O PROBLEMA:}

\section{A AUTO-ATRIBUIÇÃO VERSUS OS QUATRO ELEMENTOS}

\subsection{O PODER DA AUTO-ATRIBUIÇÃO?}

Os resultados em Inteligência - na Dissertação - mostraram que as médias das pessoas dos signos Frios (de Terra e Água) foram significativamente mais altas (RODRIGUES, 1997). Mas não poderíamos supor apenas que as pessoas da amostra dos signos da Água e da Terra sejam mais inteligentes do que as do Fogo e as do Ar; também é possível supor que as pessoas pertencentes aos períodos daqueles signos "contidos" se acreditariam mais "concentrados" e tenderiam a persistir mais na resolução de problemas, assim como se distraírem menos. Acabaram tendo em média maiores resultados de Inteligência naquela amostra, se descontarmos dos resultados a influência sazonal apenas no inverno.

As diferenças podem ter sido um fruto indireto de uma auto-atribuição, já que aqueles signos "pares", descritos astrologicamente como "auto-repressivos" em função da

analogia com seus Elementos Terra e Água, teriam "boa dose de cautela e ponderação"; 
enquanto os ímpares, em analogia com Fogo e Ar, ao contrário seriam "auto-expressivos". Teríamos aqui o efeito dos fatores "não intelectivos" da inteligência no desempenho em testes de inteligência (CATTELL, 1971), de modo que os de Terra e Água podem ter sido mais concentrados e mais persistentes na tarefa, indo assim melhor em média do que os de Fogo e Ar, dos quais a despreocupação maior pode ter diminuído a persistência na tarefa.

Se for assim sempre - a auto-atribuição de características dos signos pode influenciar o desempenho em testes de raciocínio - temos aqui um resultado inadvertido da astrologia, considerada já há tempos como um "instrumento social de auto-atribuição", mas que teria uma séria conseqüência mais além da formação de um autoconceito e até mesmo da consolidação de certas características de personalidade: os sujeitos desempenhariam em questões de raciocínio em função de características que acreditam que possuam. Aparentemente há uma auto-atribuição de capacidades, levando a melhores resultados. Aqui teríamos a passagem da auto-atribuição para a auto-eficácia, dado que Bandura (1986) descreveu como uma das fontes da auto-eficácia a persuasão verbal, neste caso advinda da leitura ou audição da descrição astrológica do próprio signo, e crença nesta descrição.

Para reforçar esta hipótese de auto-atribuição obtivemos entre os resultados da Dissertação que a Autodisciplina $\left[\mathrm{Q}_{3}\right]$ teve também variação significativa em dente-deserra $[F(1,273)=4,058, \quad p=0,045]$, mais do que a Impulsividade (aqui chamada Despreocupação $^{31}$, pela nova versão do $\left.16 \mathrm{PF}\right)$, com alta correlação negativa com esta $(\mathrm{r}=$ - 0,67). Foi mais alta para Terra e Água do que para Fogo e Ar, com r =0,43 com a Inteligência (RODRIGUES, 1997). Portanto a auto-atribuição astrológica não teria

\footnotetext{
${ }^{31}$ No Manual do 16 PF Quinta Edição (Russell, Karol, 1999) o fator é chamado inicialmente Preocupação, sendo assim definido pelos tradutores brasileiros por seu pólo oposto. Optamos por denominá-lo Despreocupação, por coerência com a anterior escala de Impulsividade e com os originais (Maraist, Russell, 2002) em inglês Impulsivity / Liveliness (Impulsividade / Vivacidade, Alegria). Há inclusive um lapso na redação do Manual, p. 47, ao opor "Sóbrio" a "Preocupado", ao invés de Despreocupado.
} 
correlação apenas com a Despreocupação e por conseqüência com a Extroversão da qual esta é componente, mas também com a autodisciplina que se expressa como "forte controle de suas emoções e de seu comportamento em geral" (ANDRADE, ALVES, 1993), em função de um "ego social ideal" (CATTELL, 1973). Vemos os resultados nas Tabelas 3 e 4. No Gráfico III observamos a tendência a seguir o padrão dente-de-serra.

Poderia ser então que as pessoas dos signos de Terra e Água, ao lerem ou ouvirem sobre seus signos e acreditarem em seus aspectos positivos e desejáveis, acabem por desenvolver maior auto-eficácia quanto à solução de problemas de raciocínio, tendo uma disposição confiante que se expressa no teste como "controle de seu comportamento em geral”32, fazendo com que abordem as questões de raciocínio do teste com mais calma, estratégia e persistência, e assim tenham ido em média melhor do que as pessoas dos signos de Fogo a Ar.

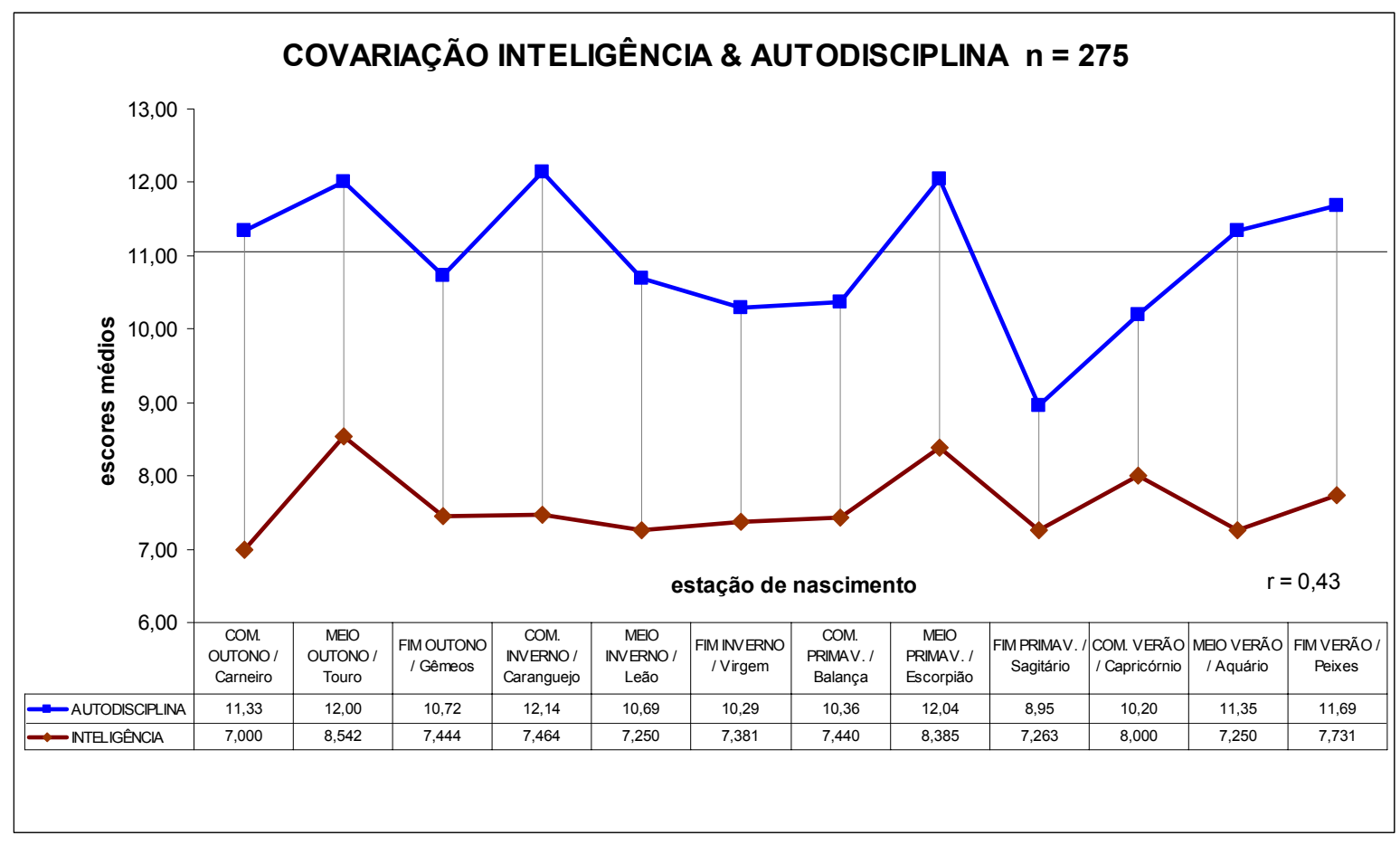

GRÁFICO III

\footnotetext{
${ }^{32}$ Icek Ajzen iguala a auto-eficácia ao "controle comportamental percebido" na Teoria do Comportamento Planejado (TPB) (1991).
} 
Tabela 3: AUTODISCIPLINA

RESUMO

\begin{tabular}{|l|l|l|l|l|}
\hline Grupo & Contagem & Soma & Média & Variância \\
\hline SIGNOS ímpares & 125 & 1326 & 10,608 & 10,27252 \\
\hline SIGNOS pares & 150 & 1711 & 11,40667 & 11,08855 \\
\hline
\end{tabular}

Tabela 4: ANOVA

\begin{tabular}{|l|l|l|l|l|l|l|}
\hline Fonte da variação & $S Q$ & $g l$ & $M Q$ & $F$ & Valor $\boldsymbol{P}$ & F crítico \\
\hline Entre grupos & 43,491 & 1 & 43,4910 & 4,0586 & $\mathbf{0 , 0 4 5}$ & 3,8757 \\
\hline Dentro dos grupos & 2925,985 & 273 & 10,71789 & & & \\
\hline$\Sigma$ & 2969,476 & 274 & & & & \\
\hline
\end{tabular}

Este fator teve resultados mais altos em nossa amostra nos grupos correspondentes aos signos teoricamente introvertidos (exceto para Fim do Inverno / Virgem e Começo do Verão / Capricórnio), há três deles com valores brutos das médias perto de 12 pontos.

No entanto, na hipótese de Rooij as pessoas nascidas nesses períodos seriam menos "suscetíveis à informação vinda de fora sobre suas personalidades", por serem de signos Negativos. Para manter esta hipótese deveríamos concluir então que aqueles teoricamente extrovertidos (signos ímpares) também se atribuiriam, juntamente com a extroversão, pouco controle do comportamento em geral, menos autodisciplina e de fato se comportariam em função disso. Mas não há uma uniformidade entre os signos ímpares, apenas quatro dentre os seis estão abaixo da média. Portanto podemos concluir que a autoatribuição de pouca disciplina não explica totalmente os resultados.

Além do mais, podemos pensar que a favorabilidade ou a desejabilidade social de certas características atribuídas a certos Elementos (Extroversão, atribuída a Fogo e Ar, tem mais aprovação social do que Introversão, atribuída a Terra e Água) leve a uma concordância diferenciada com a teoria astrológica, entre os conhecedores. Sabemos que: 
"Efeitos diferenciais de auto-atribuição podem ser obtidos ainda ao se considerar isoladamente sujeitos que possuam algumas características particulares de personalidade, que se coloquem em posições altas ou baixas no que se refere à auto-estima, defesa do eu, desejabilidade social, e outras" (DELA COLETA, 1982, p. 43).

Isto poderia fazer com que os conhecedores teoricamente extrovertidos tenham resultados significativamente mais altos em extroversão no teste do que os não conhecedores, já a mesma discrepância não ocorreria ao compararmos os conhecedores teoricamente introvertidos com os não conhecedores. De fato, uma pesquisa de Hamilton descobriu que os sujeitos da amostra julgaram as descrições dos signos ímpares como mais favoráveis do que as dos signos pares (2001).

Mas, pelos resultados combinados da Autodisciplina e da Inteligência - em direção da concentração simbolizada nos elementos Água e Terra - pareceu que serem "suscetíveis à informação vinda de fora sobre suas personalidades" também seria aplicável aos supostos introvertidos (signos pares) entre brasileiros, o que nos faria rejeitar a tese da diferenciação entre os dois grupos (ímpares e pares) exclusivamente por este traço. Portanto só separando uma nova amostra entre conhecedores e não conhecedores poderíamos discriminar até onde vai o poder da auto-atribuição, e a partir de onde começaria a atuação de algum outro fator ainda não isolado.

Resistiu para nós, portanto, esta hipótese das suscetibilidades diferentes à informação astrológica segundo os signos, dado que naquela amostra da Dissertação (RODRIGUES, 1997) não diferenciamos entre conhecedores e não conhecedores de astrologia, portanto há uma média dos resultados de ambos. E estes grupos podem ter resultados em sentidos opostos, como vimos na pesquisa de Rooij. 
Pode ser, afinal, que apareça outra real diferença entre Quentes (Fogo e Ar) e Frios (Terra e Água) independentemente do conhecimento em astrologia. Em apoio a esta hipótese, em nossa Dissertação houve no fator Apreensão [O] também uma variação significativa em dente-de-serra $[\mathrm{F}(1,273)=3,999, \mathrm{p}=0,047]$, com Fogo e Ar acima da média. A Apreensão, que é componente do fator "de segunda ordem" Ansiedade, se expressa na tendência da pessoa a ser “...deprimida, mal humorada, preocupada, cheia de pressentimentos, apreensiva. Tem uma tendência infantil a angustiar-se quando em dificuldades." (ANDRADE, ALVES, 1993, p. 25). Neste caso fica pouco plausível que os de Fogo e Ar se atribuam tais características. No entanto pode haver uma diferença real independente do conhecimento em astrologia, que tenha levado ao mesmo tempo a resultados médios maiores em Apreensão para Fogo e Ar e em decorrência resultados médios piores em Inteligência.

Mais ainda, temos que a Autodisciplina também é componente negativa do fator Ansiedade, conforme veremos nas equações dadas adiante. Esta diferença real entre Frios e Quentes seria então capturável nos resultados dos não conhecedores da astrologia. Isto gera para nós uma nova hipótese quanto à Ansiedade, que não tinha sido considerada pelos outros pesquisadores.

Temos então que enveredar pela segunda vertente, avaliando a possibilidade de variações aparentemente astrológicas que não dependam do conhecimento astrológico. 


\subsection{O PODER DOS ELEMENTOS?}

\subsubsection{O CIRCUMPLEXO INTERPESSOAL}

Uma possível fonte para a compreensão da regularidade da variação da personalidade segundo um esquema de origem astrológica é o estudo das dimensões fundamentais de atribuição de personalidade. Sabemos que a escala Frio-Quente, tendo sido originada na física aristotélica, foi sendo levada progressivamente ao domínio da biologia humana desde a medicina de Galeno, e daí para a psicologia - desde Pavlov, por exemplo, o que deu subsídio teórico para aquela hipótese inicial de Eysenck (1973) sobre a diferença em extroversão entre Fogo e Ar (Quentes) comparados a Terra e Água (Frios). Já se sabe, desde as pesquisa pioneiras de Solomon Asch (1966), que o atributo de "Frio"33 e seu oposto "Afetuoso" 34 são adjetivos nucleares em percepção de pessoas: são mais influentes do que outros adjetivos na formação de impressão através de uma descrição verbal sobre uma pessoa desconhecida (RODRIGUES, 1996). Também há outra escala igualmente importante, relativa à percepção da diretividade da pessoa, que é a referente à dominação. Os estudos de cognição social têm demonstrado o poder estruturador destas dimensões, e a maioria dos modelos criados demonstra que estas dimensões são ortogonais entre si, porém entrelaçadas, gerando então um modelo circular. Deu-se o nome de "circumplexo interpessoal" a este "encadeamento" ou "entrelaçamento" circular de características de personalidade dentro do qual julgamos as pessoas, no qual estas duas dimensões são os eixos estruturantes. Usamos aqui um dos modelos mais recentes, que inclui as dimensões intermediárias da extroversão e da desconfiança. Para J. S. Wiggins, seu criador, pode ser considerado um mapa cognitivo que operacionaliza o domínio das

\footnotetext{
${ }^{33}$ Cold.

${ }^{34}$ Warm.
} 
“ações interpessoais" (WIGGINS, 1979). O circumplexo interpessoal oferece então, em cada extremo de seus eixos, "protótipos" de personalidade.

Este modelo circumplexo de Wiggins se presta para nosso propósito, porque justamente foi testado em relação aos quatro Elementos (MARTINDALE, MARTINDALE, 1988). Quando se pediu para um grupo de voluntários que agrupasse uma série de palavras embaralhadas, relativas aos extremos das dimensões, aos quatro temperamentos de Galeno e a outras palavras conforme imagens dos quatro Elementos, os resultados foram em conformidade com o previsto, o que está expresso na Figura 6. Ali temos os quatro Elementos colocados em complemento ao Circumplexo Interpessoal.

Para os pesquisadores, que se apoiaram nos escritos de Gaston Bachelard sobre os Elementos, esta correlação demonstra que há um sistema intuitivo para classificação da realidade, levada do material ao interpessoal, num processo de imaginação por analogia. Bachelard (1942), afirmou a importância do estudo da "imaginação material”, além da “imaginação formal”: “... acreditamos possível estabelecer, no reino da imaginação, uma lei dos quatro elementos, que classifica as diversas imaginações materiais conforme elas se associem ao fogo, ao ar à água ou à terra.” (2002, p. 3). Haveria, nas palavras daquele filósofo francês estudioso da imaginação e do devaneio, uma correspondência entre os Elementos e os temperamentos que ...”funciona no nível pré-consciente."35

Os autores do experimento afirmam que estas podem ser também “... as dimensões mais básicas da personalidade., 36

\footnotetext{
35 "This fits the theory proposed by Bachelard, wich holds that the correspondence between the elements and the temperaments functions at a preconscious level." (MARTINDALE, MARTINDALE, p. 843).

36 "This discovery supports the contention that these may be the most basic dimensions of personality." (MARTINDALE, MARTINDALE, p. 843).
} 


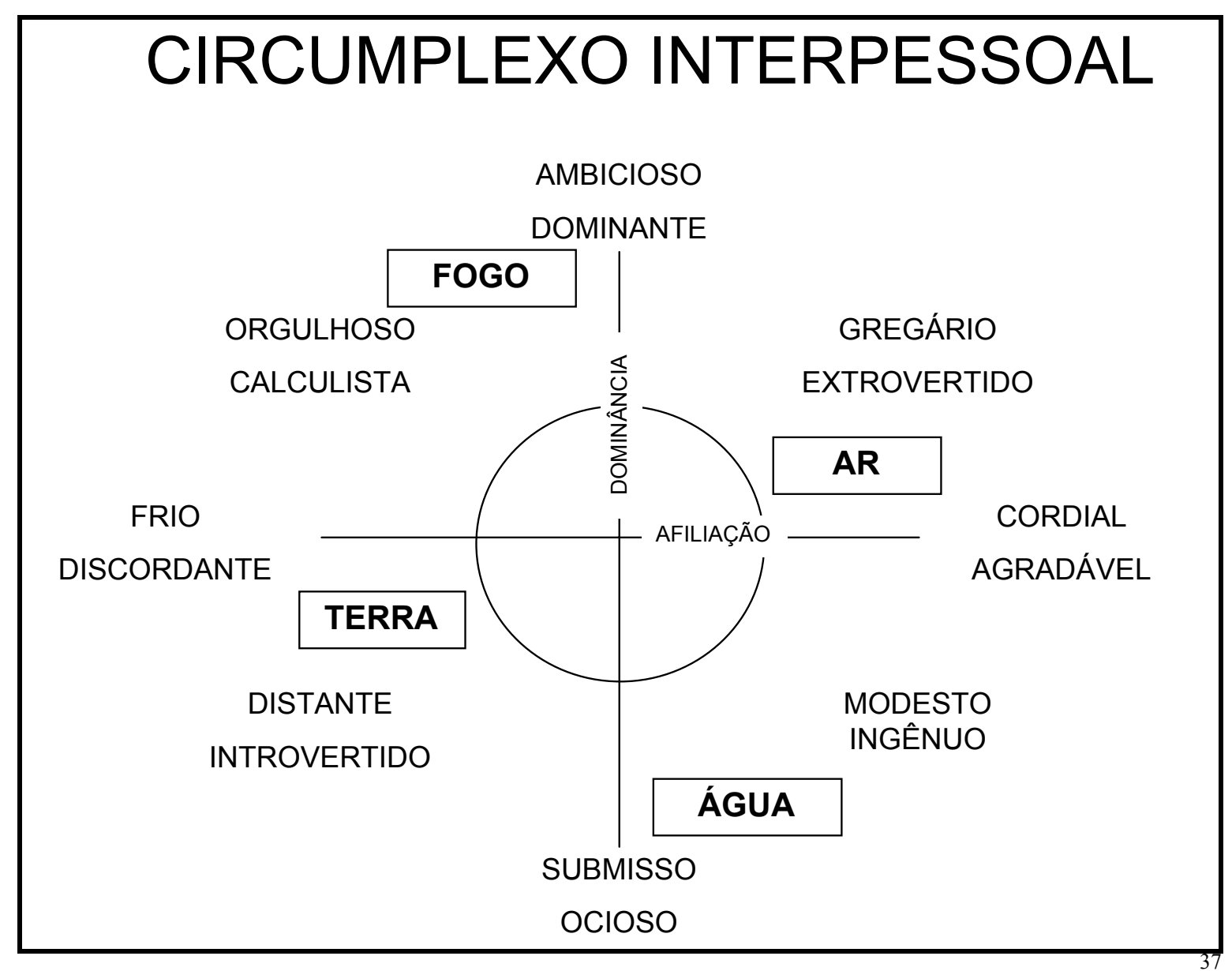

Figura 6: O Circumplexo Interpessoal e os Quatro Elementos

Se assumirmos que: "tanto o ator quanto o observador envolvidos em um fenômeno qualquer usam os mesmos processos de inferência para chegar às características disposicionais capazes de explicar aquele dado efeito." (DELA COLETA, 1982), podemos supor que, além de servir para perceber os outros, há também um processo de estabelecimento do autoconceito também nos limites deste mesmo circumplexo, ou seja, uma auto-atribuição de características básicas, uma extrema de cada eixo. Isto, uma vez feito, poderia ser estabilizado numa dada personalidade, ainda mais porque há uma modelação recíproca nos contatos sociais: cordialidade / afabilidade em um atrai o mesmo

\footnotetext{
${ }^{37}$ Baseado no modelo de WIGGINS, 1979; e nos resultados de MARTILDALE \&MARTINDALE, 1988)
} 
em outro, assim como o pólo oposto de frieza / discordância; e a submissão atrai dominância, e vice-versa. Então a pessoa, mesmo que não acredite na astrologia, em geral sabe por algum meio sobre seu signo, seu Elemento e as características correspondentes (EYSENCK, NIAS, 1982, p. 58), e isto poderia funcionar no nível pré-consciente como pré-indução de auto-atribuição, dada a disponibilidade destas imagens primordiais. Então provavelmente começa uma auto-atribuição - baseada em auto-observação consciente, e não em astrologia - que será reforçada pelos contatos sociais.

Desta forma poderia haver um comportamento aproximado às predições astrológicas, mesmo que a pessoa atualmente declarasse não acreditar em astrologia. Assim, uma das implicações disto é que haveria diferenças de personalidade segundo os Elementos dos signos até mesmo entre os classificados como não conhecedores da astrologia. Isto pode ser testado numa hipótese, como fizemos na pesquisa em seguida.

Ao apresentarmos os resultados, seguiremos a relação que mantêm para o Hemisfério Sul as mesmas seqüências de Elementos e Ritmos do Norte, ainda que as estações aqui sejam invertidas, para poder avaliar adequadamente a possível influência conjunta das variações independentes do conhecimento astrológico e das variações dependentes de auto-atribuição de características segundo as descrições tradicionais dos signos, que foram trazidas ao Hemisfério Sul sem nenhuma adaptação.

$\mathrm{Na}$ interpretação dos resultados, mantemos então em mente que a única divisão natural do ciclo anual que pode haver é a das as estações do ano, com seus inícios marcados pelos Equinócios e Solstícios, mas que cada uma pode ser subdividida em três Ritmos ou etapas, e isto pode ter ainda uma fraca base natural em função da mudança climática gradual observável. Estas duas divisões podem ser totalmente independentes de uma subdivisão segundo Elementos, já que esta foi construída intencionalmente pelos 
astrólogos. Ou mais ainda, se há alguma divisão em conformidade com as Triplicidades, os Elementos poderiam não estar naqueles lugares descritos por Ptolomeu, poderiam ser intercambiados. Deste modo, nossa investigação permite relacionar as variáveis de personalidade dependentes de uma base natural (ambiental ou genética) e a influência confirmadora ou modificadora advinda das crenças e do autoconceito do indivíduo.

A propósito, outra hipótese de pesquisa surge da diferenciação encontrada por Rooij entre conhecedores e não conhecedores da astrologia. Para este pesquisador, como vimos, a diferença surgiu na Extroversão, maior em média para os conhecedores. Já a pesquisa de Hamilton sobre crença na astrologia apontou que aqueles nascidos nos signos ímpares expressaram mais esta crença do que aqueles nascidos nos signos pares. A autora conclui que estes achados sugerem que um dos determinantes da aceitação da astrologia é a favorabilidade da descrição do caráter que ela oferece para certos signos (2001). No entanto, contrariando os resultados desta pesquisa, Wunder (2003) encontrou, em 1700 sujeitos na Alemanha, uma distribuição da crença na astrologia uniforme entre os signos, mostrando haver "crentes" mesmo entre aqueles de signos com traços astrológicos mais desfavoráveis ${ }^{38}$. Pode ser que a maior favorabilidade da descrição apenas leve a uma maior concordância do sujeito com a descrição de seu signo, mas que a menor favorabilidade da descrição não impeça um sujeito de um signo teoricamente introvertido de acreditar na astrologia. Isto demonstra que a crença na astrologia depende ao menos de outro fator a mais do que a favorabilidade da descrição do signo. Delineia-se a idéia de que a crença na astrologia, além de relacionar-se à necessidade de "compreender", também serve para "predizer" e "controlar", ou seja, vale a hipótese de que a crença na astrologia e o conhecimento decorrente é maior para os mais ansiosos, o que também investigamos.

\footnotetext{
38 "...the mean belief scores were almost exactly the same for all sign groups."
} 


\section{OBJETIVOS DA PESQUISA}

\subsection{OBJETIVO GERAL}

Desejamos avaliar inicialmente as relações entre a auto-atribuição, o autoconceito e a habilidade geral a partir de crenças sobre a própria personalidade e sua interação com o mundo: como a esfera da personalidade - avaliada sob o ângulo do autoconceito construído socialmente - e a esfera das habilidades, sob o ângulo da habilidade geral, condicionam-se mutuamente. Replicamos a pesquisa de Rooij e seus colaboradores (1994) com sujeitos brasileiros, do mesmo modo controlando o "conhecimento da astrologia" dos sujeitos testados, mas fizemos uma "replicação por constructo" (LYKKEN, 1968) dado que utilizamos o $16 \mathrm{PF}$ com todas as suas escalas, de modo a investigar o quanto a autoatribuição causa diferenças nos resultados das escalas do 16 PF entre conhecedores e não conhecedores da astrologia, delimitando se o conhecimento da astrologia condiciona de modo mensurável o autoconceito entre brasileiros; e também se há variações de base astrológica independentes da crença, com a avaliação da covariação da Inteligência (Habilidade Geral) com as dimensões da personalidade, tanto nos 16 "fatores primários" quanto em três dos cinco "de segunda ordem" derivados daqueles. Intentamos também avaliar se certas características de personalidade em comum entre os conhecedores é que os levaram a buscar o conhecimento da astrologia. Deste modo avaliamos o efeito mútuo da personalidade e do conhecimento das características do signo astrológico. 


\subsection{OBJETIVOS ESPECÍFICOS}

Os resultados da pesquisa aplicam-se em quatro campos:

a) Pesquisa sobre auto-atribuição de características e suas conseqüências no autoconceito.

b) Pesquisa sobre relações entre auto-atribuição de características, inteligência, e autoeficácia.

c) Pesquisa sobre interação entre fatores de personalidade, locus de controle e conhecimento da astrologia.

d) Pesquisa sobre variações de base astrológica em fatores de personalidade. 


\section{HIPÓTESES}

A partir da explanação anterior, delineamos cinco hipóteses, sendo as três primeiras derivadas dos achados de Rooij, e as duas últimas derivadas dos resultados da Dissertação (RODRIGUES, 1997): A $1^{\text {a }}$ afirma a auto-atribuição como causa da variação de base astrológica na Extroversão. A $2^{\mathrm{a}}$ afirma maior suscetibilidade à informação vinda de fora sobre suas personalidades para os de signos Quentes em relação aos Frios. A $3^{\mathrm{a}}$ prediz que os conhecedores de astrologia são mais extrovertidos do que os não conhecedores. A $4^{\mathrm{a}}$ hipótese prediz que os conhecedores de astrologia são mais ansiosos do que os não conhecedores; a $5^{\text {a }}$ hipótese afirma a variação da Inteligência, entre os não conhecedores da astrologia, como dependente da variação da Ansiedade segundo o padrão dente-deserra.

$1^{\text {a }}$ HIPÓTESE: Entre os conhecedores, as médias grupais das escalas componentes da Extroversão são significativamente mais altas para os signos Quentes do que para os signos Frios, mas o mesmo não ocorre entre as médias grupais dos não conhecedores. (Hipótese da auto-atribuição = HA-A) 
$2^{a}$ HIPÓTESE: Há uma discrepância significativa das médias das escalas componentes da Extroversão nos Quentes \& conhecedores, em relação às médias dos Quentes \& não conhecedores, e o mesmo não ocorre com as médias dos Frios \& conhecedores em comparação com as médias dos Frios \& não conhecedores. (Hipótese da suscetibilidade à informação diferenciada pela dimensão Frio-Quente = HSFQ)

$3^{\text {a }}$ HIPÓTESE: Os conhecedores se diferenciam dos não conhecedores significativamente para mais nas médias das escalas componentes da Extroversão. (Hipótese do conhecimento astrológico diferenciado por Extroversão = HCE)

$4^{a}$ HIPÓTESE: Os conhecedores se diferenciam dos não conhecedores significativamente para mais nas médias das escalas componentes da Ansiedade. (Hipótese do conhecimento astrológico diferenciado por Ansiedade $=\mathrm{HCA}$ )

$5^{\text {a }}$ HIPÓTESE: Entre os não conhecedores, as médias grupais das escalas componentes da Ansiedade são significativamente mais altas para os signos Quentes do que para os signos Frios, mas o mesmo não ocorre entre as médias grupais dos conhecedores. (Hipótese da Ansiedade diferenciada pela dimensão Frio-Quente = HAFQ) 


\section{METODOLOGIA}

\subsection{SUJEITOS}

Foram reunidos no estudo os resultados de 750 sujeitos até o meio de 2004, alunos entre os primeiro e quarto anos de duas universidades em São José dos Campos - UNIP e UNIVAP - dos cursos: Administração de Empresas, Propaganda e Marketing, Publicidade e Propaganda, Turismo, Jornalismo. De 750 testes aplicados foram selecionados 589, dado que eliminamos os testes de sujeitos com idades inferiores a 19 anos e seis meses, em função das variações conhecidas dos traços até por volta desta idade, conforme demonstrado por Cattell (1973). Também houve casos de questionários incompletos, e de pessoas que não responderam as questões de conhecimento sobre astrologia. Tivemos uma exclusão total de 161 casos. A composição da amostra está na Tabela 5.

Tabela 5: COMPOSIČ̃̃ DA AMOSTRA

\begin{tabular}{|c|c|c|c|}
\hline & HOMEM & MULHER & $\Sigma$ \\
\hline CONHECEDORES & 112 & 96 & $208_{(35,31 \%)}$ \\
\hline NÃO CONHECEDORES & 156 & 225 & $381_{(64,69 \%)}$ \\
\hline$\Sigma$ & $268_{(45,50 \%)}$ & $321_{(54,50 \%)}$ & 589 \\
\hline
\end{tabular}


Para dividir as pessoas entre os signos, adotamos o início dos signos Cardeais conforme a proposta astronômica dos inícios médios das estações: 20 de Março para Carneiro, 21 de Junho para Caranguejo, 23 de Setembro para Balança e 22 de Dezembro para Capricórnio (MURGEL, PERISSINOTTO, 1988). Adotamos como início dos signos Fixos e Mutáveis - que seguem os Cardeais - as datas médias, conforme a divisão proposta de 30 em 30 graus de longitude zodiacal a partir dos Equinócios e Solstícios: 20 de Abril para Touro, 21 de Maio para Gêmeos; 22 de Julho para Leão, 23 de Agosto para Virgem; 23 de outubro para Escorpião, 22 de Novembro para Sagitário; 20 de Janeiro para Aquário, 19 de Fevereiro para Peixes (MURGEL, PERISSINOTTO, 1988).

No entanto, para as pessoas que nasceram nos dias de limite entre signos levamos em consideração o signo que declararam, para garantir a possibilidade do efeito da autoatribuição. Verificamos estas datas, conforme definidas por um manual astrológico (PARKER \& PARKER, 1982), definindo o limite de um dia de diferença como aceitável, dado que o dia de mudança de signo não é astronomicamente fixo, por diferenças entre o ano astronômico e o calendário. Em caso de discrepância maior, eliminamos os dados do sujeito da amostra. A distribuição da amostra é a detalhada na Tabela 6. 
Tabela 6: DISTRIBUIÇÃO DA AMOSTRA

\begin{tabular}{|c|c|c|c|c|}
\hline \multicolumn{2}{|c|}{ SUGESTÃO: PSICOLOGIA } & CONHECEDORES & $\begin{array}{c}\text { NÃO } \\
\text { CONHECEDORES }\end{array}$ & $\Sigma \Sigma$ \\
\hline \multirow{12}{*}{$\begin{array}{c}\text { ESTAÇÃO DE } \\
\text { NASCIMENTO } \\
\text { / (INÍCIO) }\end{array}$} & COMECO DO OUTONO $(20 / 03)$ & 9 & 16 & 25 \\
\hline & MEIO DO OUTONO $(20 / 04)$ & 6 & 18 & 24 \\
\hline & FIM DO OUTONO (21/05) & 11 & 15 & 26 \\
\hline & COMEÇO DO INVERNO $(21 / 06)$ & 12 & 16 & 28 \\
\hline & MEIO DO INVERNO (22/07) & 9 & 11 & 20 \\
\hline & FIM DO INVERNO (23/08) & 11 & 27 & 38 \\
\hline & COM. DA PRIMAVERA $(23 / 09)$ & 5 & 17 & 22 \\
\hline & MEIO DA PRIMAVERA (23/10) & 7 & 27 & 34 \\
\hline & FIM DA PRIMAVERA $(22 / 11)$ & 8 & 14 & 22 \\
\hline & COMEÇO DO VERÃO $(22 / 12)$ & 6 & 22 & 28 \\
\hline & MEIO DO VERÃO $(20 / 01)$ & 9 & 23 & 32 \\
\hline & FIM DO VERÃO $(19 / 02)$ & 8 & 16 & 24 \\
\hline & $\Sigma$ & 101 & 222 & 323 \\
\hline \multicolumn{2}{|c|}{ SUGESTÃO: ASTROLOGIA } & CONHECEDORES & $\begin{array}{c}\text { NÃO } \\
\text { CONHECEDORES }\end{array}$ & \\
\hline \multirow{13}{*}{$\begin{array}{l}\text { ESTAÇÃO DE } \\
\text { NASCIMENTO } \\
\text { / (INÍCIO) }\end{array}$} & COMEÇO DO OUTONO (20/03) & 9 & 13 & 22 \\
\hline & MEIO DO OUTONO $(20 / 04)$ & 9 & 9 & 18 \\
\hline & FIM DO OUTONO $(21 / 05)$ & 6 & 15 & 21 \\
\hline & COMEÇO DO INVERNO (21/06) & 10 & 19 & 29 \\
\hline & MEIO DO INVERNO (22/07) & 9 & 15 & 24 \\
\hline & FIM DO INVERNO (23/08) & 11 & 14 & 25 \\
\hline & COM. DA PRIMAVERA (23/09) & 6 & 9 & 15 \\
\hline & MEIO DA PRIMAVERA (23/10) & 12 & 10 & 22 \\
\hline & FIM DA PRIMAVERA (22/11) & 7 & 15 & 22 \\
\hline & COMEÇO DO VERÃO $(22 / 12)$ & 10 & 13 & 23 \\
\hline & MEIO DO VERÃO $(20 / 01)$ & 7 & 16 & 23 \\
\hline & FIM DO VERÃO (19/02) & 11 & 11 & 22 \\
\hline & $\Sigma$ & 107 & 159 & 266 \\
\hline & $\Sigma \Sigma$ & 208 & 381 & 589 \\
\hline
\end{tabular}


Apresentamos nesta Tese os resultados e as análises feitas com esta amostra de 589 brasileiros. A faixa de idade da amostra foi de 19 anos e 6 meses a 51 anos e 1 mês, esta amplitude foi possível dado que muitos desses cursos são noturnos, com alunos de idades bem variadas, desde pessoas que estão iniciando o $3^{\circ}$ Grau logo em seguida do Colegial, até aqueles que estão retomando os estudos depois de muitos anos de vida exclusivamente profissional, passando pelos que estão fazendo uma segunda formação universitária. A média de idade foi 26 anos e 5 meses. Para comparação com a população geral, há uma faixa de idade ideal com média por volta dos 30 anos, que foi a idade usada para determinar os valores médios na padronização do 16 PF nos EUA. Nossa amostra aproxima-se razoavelmente deste ideal, com viés para menos, devido ao público universitário pesquisado. 


\subsection{INSTRUMENTOS}

Realizamos as aplicações dos testes utilizando o 16 PF - Questionário dos 16 Fatores de Personalidade, traduzido por Eugênia Moraes de Andrade e Dulce de Godoy Alves, publicado pela CEPA, Rio de Janeiro. Os autores, para realizarem sua padronização no Brasil, basearam-se no "Handbook for the Sixteen Personality Factor Questionnaire, The 16 P.F. Test”, publicado em 1964 nos EUA. Já existe desde 1993 nos EUA e desde 1999 no Brasil a quinta edição do 16 PF, tendo sido padronizado lá com 2500 sujeitos (MARAIST, RUSSELL, 2002) e aqui com 1152 casos (RUSSELL, KAROL, 1999). Mas trata-se de um novo questionário dado que grande parte dos itens foi renovada, portanto não teríamos um bom termo de comparação com resultados anteriores. E desejamos manter esta comparabilidade dos dados. Aproveitamos então desta quinta edição apenas as novas definições das escalas. As variáveis do 16 PF que usamos estão descritas no Anexo III com suas definições técnicas em inglês e português, e suas designações não técnicas, por adjetivos. Os fatores primários do $16 \mathrm{PF}$ são "oblíquos", não totalmente independentes 39 . Permite-se assim criar, por uma segunda fatoração de resultados, fatores "de Segunda Ordem": Extroversão, Ansiedade, Aprumo Vivaz, Independência e Controle. Pesquisas têm demonstrado que Extroversão, Ansiedade e Controle têm alta correlação (COMREY, LAW, NOLLER, 1987; GOLDBERG, 1992) com três dos Cinco Grandes, ou Cinco Magníficos (Big Five) fatores de personalidade, que têm sido chamados em inglês de Extraversion (Extroversão), Neuroticism (Neuroticismo) e Conscientiousness (Conscienciosidade), além de Agreeableness (Afabilidade) e Openness (Abertura) (KLINE, BARETT, 1983).

\footnotetext{
${ }^{39}$ Uma característica do teste que tem causado muitas críticas. Porém isto é útil para nossos objetivos de avaliar o possível efeito transversal de um fator "astrológico" ou "cosmobiológico", ou da auto-atribuição.
} 
A revalidação do 16 PF em 1986 permitiu criar novas "equações de estimação" dos Fatores de Segunda Ordem. Ainda que estudos de re-fatoração do 16 PF tenham extraído menos do que 16 fatores primários - sete por Kline e Barrett (1983), doze por Matthews (1989), Extroversão e Ansiedade sempre aparecem nitidamente.

Repetimos em seguida as definições daquelas que compõem os Fatores de Segunda Ordem avaliados, além da Inteligência (ANDRADE, ALVES, 1993, pp. 19-27). As variáveis em questão são definidas assim (entre parênteses a sigla original e os conceitos em inglês, em alguns casos há dois nomes porque houve uma redefinição na $5^{\mathrm{a}}$ Edição):

Expansividade (A, Warmth), tendência a ser "afetivo, condescendente, participante”, uma pessoa “...afável, complacente, emocionalmente expressiva, pronta a cooperar, atenciosa para com os outros, de bom coração...”.

A Inteligência (B, Intelligence / Reasoning) é dada pelo grau de vivacidade na apreensão de idéias, pela rapidez para aprender, pelo uso do pensamento abstrato.

Estabilidade Emocional (C, Stability / Emotional Stability) é a tendência da pessoa a ser "emocionalmente madura, estável, calma, com visão realista da vida, imperturbável, com ego forte...". Tem maior "Força do Ego".

Despreocupação (F, Impulsivity / Liveliness) é uma característica infantil que sendo conservada no adulto "leva a pessoa a ser "jovial, ativa, tagarela, franca, expressiva, agitada, despreocupada". "Pode ser impulsiva e volúvel".

Consciência (G, Conformity / Rule-Consciousness) é e tendência da pessoa a ser “...escrupulosamente correta, dominada pelo senso do dever, perseverante, responsável, ordenada...". Apresenta maior "Força do Superego".

Desenvoltura (H, Boldness / Social Boldness) torna a pessoa ...sociável , afoita, pronta e experimentar coisas novas, espontânea e muito rica em reações emotivas.”. 
Desconfiança (L, Suspiciousness / Vigilance) é a tendência da pessoa "a ser suspeitosa, a levantar dúvidas, a desconfiar”. “... é obstinada em suas opiniões - não confia ns outros - e interessada na vida mental, interior". Geralmente leva a agir de caso pensado.

Apreensão (O, Insecurity / Apprehension) é a tendência a ser “...deprimida, mal humorada, preocupada, cheia de pressentimentos, apreensiva." Tendência infantil a angustiar-se em dificuldades. Altos resultados são comuns em muitos grupos clínicos.

Auto-Suficiência $\left(\mathbf{Q}_{\mathbf{2}}\right.$, Self-Sufficiency / Self-Reliance) é a tendência da pessoa a ser “...independente por temperamento... tomando decisões e agindo por conta própria."

Autodisciplina $\left(\mathbf{Q}_{\mathbf{3}}\right.$, Self-discipline / Perfectionism) é a tendência a ser "socialmente correto, comandado pela auto-imagem", com "forte controle de suas emoções e de seu comportamento em geral; é atenta às regras sociais...”.

Tensão $\left(\mathbf{Q}_{4}\right.$, Tension) em níveis altos leva a pessoa a ser “tensa, excitável, inquieta, agitada, impaciente. Está sempre fatigada, mas incapaz de permanecer inativa.”.

Para obtenção dos fatores de segunda ordem utilizamos equações as de estimação (estimation equations) publicadas em 1986, depois de uma revalidação do tipo "crossvalidation" realizada por Krug e Johns com 17.381 sujeitos nos EUA (KRUG, JOHNS, 1986). No 16 PF Quinta Edição estes fatores são chamados Fatores Globais, com "equações de especificação"40 ligeiramente diferentes daquelas que usamos aqui, em função de ser um novo questionário.

Extroversão é a tendência da pessoa a ser “...socialmente expansiva, sem inibições, hábil em tratar e manter contatos interpessoais, ...”. Ao contrário, na Introversão a pessoa tende a ser “....acanhada, auto-suficiente e inibida em suas relações pessoais". (ANDRADE, ALVES, 1993, p. 33).

\footnotetext{
${ }^{40}$ Estas equações são obtidas por regressão estatística múltipla.
} 
A equação de estimação da Extroversão é: Extroversão = [0,28.A (Expansividade)] $+[0,35 . \mathbf{F}$ (Despreocupação) $]+[0,36 . \mathbf{H}$ (Desenvoltura) $]-\left[0,38 . \mathbf{Q}_{2}\right.$ (Auto-Suficiência) $]+$ 2,15 (KRUG, JOHNS, 1986).

Há uma correlação alta entre a Extroversão medida no EPI $^{41}$ e a Extroversão medida no $16 \mathrm{PF}$, segundo mediu-se pelas cargas fatoriais das escalas: "A" $=(0,41)$, "F" $=$ $(0,65), " \mathbf{H} "=(0,77)$ e “ $\mathbf{Q}_{2} "=(-0,43)$. E medida diretamente no EPI: como o fator $\mathrm{E}=$ (0,71), na pesquisa de correlação de Comrey, Law e Noller (1987).

Controle une a escrupulosidade e a perseverança com forte controle das emoções em vista das regras sociais. A equação de estimação do Controle (que se equipara com a Conscienciosidade) que usamos é: Controle $=\left[0,68 . \mathbf{G}\left(\right.\right.$ Consciência $\left.\left.^{42}\right)\right]+\left[0,49 \cdot \mathbf{Q}_{3}\right.$ (Autodisciplina)] - 0,94 (KRUG, JOHNS, 1986).

Ansiedade “... indica que a pessoa está insatisfeita com o grau em que é capaz de enfrentar as exigências da vida e de realizar o que deseja". Se "muito alta perturba o desempenho em geral e produz distúrbios físicos.” (ANDRADE, ALVES, 1993, p. 33). A equação de estimação da Ansiedade (que se equipara com o Neuroticismo) é: Ansiedade = - [0,29.C (Estabilidade emocional) $]-[0,12 . \mathbf{H}$ (Desenvoltura) $]+[0,13 . \mathbf{L}$ (Desconfiança) $]$ $+[0,34 . \mathbf{O}$ (Apreensão) $]-\left[0,12 . \mathbf{Q}_{\mathbf{3}}\right.$ (Autodisciplina) $]+\left[0,34 . \mathbf{Q}_{\mathbf{4}}(\right.$ Tensão) $]+3,96$ (KRUG, JOHNS, 1986).

Há também uma correlação alta entre o Neuroticismo medido no EPI e a Ansiedade medida no 16 PF, segundo as escalas: “O” $=(0,68), " \mathbf{Q}_{4} "=(0,68), " \mathbf{C} "=(-0,42)$ e "L" $=$ (0,38). E medida diretamente no EPI: como o fator $\mathrm{N}=(0,73)$ (COMREY, LAW, NOLLER, 1987).

\footnotetext{
${ }^{41}$ EPI: Eysenck Personality Inventory

${ }^{42}$ Anteriormente Cattell também definiu este fator $\mathbf{G}$ como Força de Superego, sendo perseverança, circunspeção, e conformidade.
} 
Para controlar a variável "conhecimento da astrologia" foi criado um questionário para obter as mesmas informações citadas por Rooij, sendo aplicado após (para o grupo da sugestão: "Psicologia") ou antes de (para o grupo da sugestão: “Astrologia") os sujeitos terem entregado o questionário respondido. Consta das seguintes questões:

a) Você acredita em Astrologia?

b) Você acredita em influências astrológicas na personalidade?

c) Você acredita que as pessoas correspondem às descrições de seus signos astrológicos?

d) Você sabe qual é seu signo? Se sim, qual é?

e) Você pode descrever três características de seu signo? Se sim, quais são?

f) Você pode descrever o que é Ascendente?

g) Você sabe descrever o que é Meio-do-Céu?

h) Você sabe descrever o que são Casas astrológicas?

As três últimas questões são feitas para avaliar o grau de conhecimento astrológico da pessoa, pois são informações que só quem estuda mais profundamente astrologia pode ter. 


\subsection{PROCEDIMENTOS}

Foi feita uma replicação por constructo da metodologia utilizada na pesquisa de Rooij (1994), ou seja, replicamos a pesquisa utilizando apenas os mesmos procedimentos, mas com teste e população diferentes (LYKKEN, 1968). Responder o questionário é parte opcional da matéria Psicologia na maioria desses cursos, ao abordarmos o tema personalidade, desde 1999. Os alunos respondem voluntariamente os questionários, paralelamente a outro teste que é aplicado, e o intuito é dar os resultados dos dois testes e compará-los. Os alunos não são obrigados a responderem os testes, mas há um estímulo devido ao fato de terem interesse em saberem sobre suas personalidades. Assim os resultados podem ser aproveitados posteriormente. Isto facilita uma parte do estudo que é a composição de parte da amostra com sujeitos que recebem a sugestão "Psicologia", pois após a entrega dos testes é pedido para eles que respondam uma "pesquisa sobre personalidade" com as questões adicionais sobre data de nascimento e conhecimento da astrologia. Para aqueles sujeitos a quem foi dada a sugestão "Astrologia" através da frase "Esta é uma pesquisa sobre Astrologia", foi explicado o intuito da pesquisa, e foi pedido o consentimento para uso dos resultados conforme Anexo II.

Foi então feita a ANOVA em três níveis relacionando cada escala com: Signo (Ímpar (ou Quente) vs. Par (ou Frio)) X Conhecimento astrológico (Descrição ou não de três características) X Sugestão (Psicologia vs. Astrologia). Tratamos todos os resultados em valores brutos, o que é necessário para a precisão das medidas, já que com a padronização perdem-se diferenças reais nas contagens que podem fazer diferenças num teste estatístico sensível que é a ANOVA.

Para aprofundamento da análise também utilizamos o coeficiente de correlação de Pearson, o teste $t$ para comparação de médias, e a regressão linear entre escalas. 
Classificamos os sujeitos que responderam acreditar na astrologia e nas influências astrológicas, que sabiam seus signos e descreveram três características que correspondessem às citadas no Anexo I: DESCRIÇÕES DOS SIGNOS POR “TRAÇOS”, como conhecedores; e aqueles que responderam não acreditar na astrologia nem em influências astrológicas e não descreveram três características como não conhecedores. Nos casos em que os sujeitos responderam acreditar na astrologia, mas não em influências astrológicas na personalidade e não descreveram características houve uma classificação como não conhecedores. Sujeitos que responderam não acreditar na astrologia nem em influências astrológicas, mas que descreveram três características foram classificados como conhecedores.

Em muitos casos os sujeitos disseram não acreditar nem na astrologia nem nas influências astrológicas na personalidade, mas sabiam seus signos, sem descrever três características, foram classificados como não conhecedores.

A pergunta "Você acredita que as pessoas correspondem às descrições de seus signos astrológicos?", foi colocada apenas como um controle para definir melhor o conhecimento das características em casos de discrepância entre crença e conhecimento, dado que para saber sobre a correspondência é necessário saber as características. 


\section{RESULTADOS}

\subsection{AMOSTRA DIVIDIDA ENTRE NÃO CONHECEDORES E CONHECEDORES DA ASTROLOGIA}

Apresentamos em seguida a Extroversão, para testar a hipótese da autoatribuição $^{43}$. Para os Fatores de Segunda Ordem, além da Extroversão, avaliamos todos os fatores primários que os compõem, dado que pode haver variações independentes por um critério astrológico ou por um critério sazonal, conforme mostramos da Dissertação (RODRIGUES, 1997).

Reavaliamos também a Inteligência e a Autodisciplina, em função da correlação encontrada na Dissertação, junto aos fatores que mostraram médias significativamente diferentes segundo a hipótese dos Elementos. Em seguida os fatores cujas médias divergiram significativamente entre os não conhecedores e os conhecedores da astrologia, avaliando a hipótese da função astrológica. Também os fatores que covariaram significativamente com a Inteligência, segundo a hipótese da diferença de base astrológica entre signos Quentes e Frios.

Apresentamos todos os resultados das médias em valores brutos.

\footnotetext{
${ }^{43}$ É medida através de 46 itens.
} 


\subsubsection{EXTROVERSÃO NO GRUPO DE NÃO CONHECEDORES DA ASTROLOGIA}

Podemos perceber no Gráfico IV que para o grupo de não conhecedores há uma tendência inicial a uma variação em dente-de-serra oposto ao previsto, com as médias dos pares acima das dos ímpares, conforme fora encontrado por Rooij e se vê no Gráfico I.

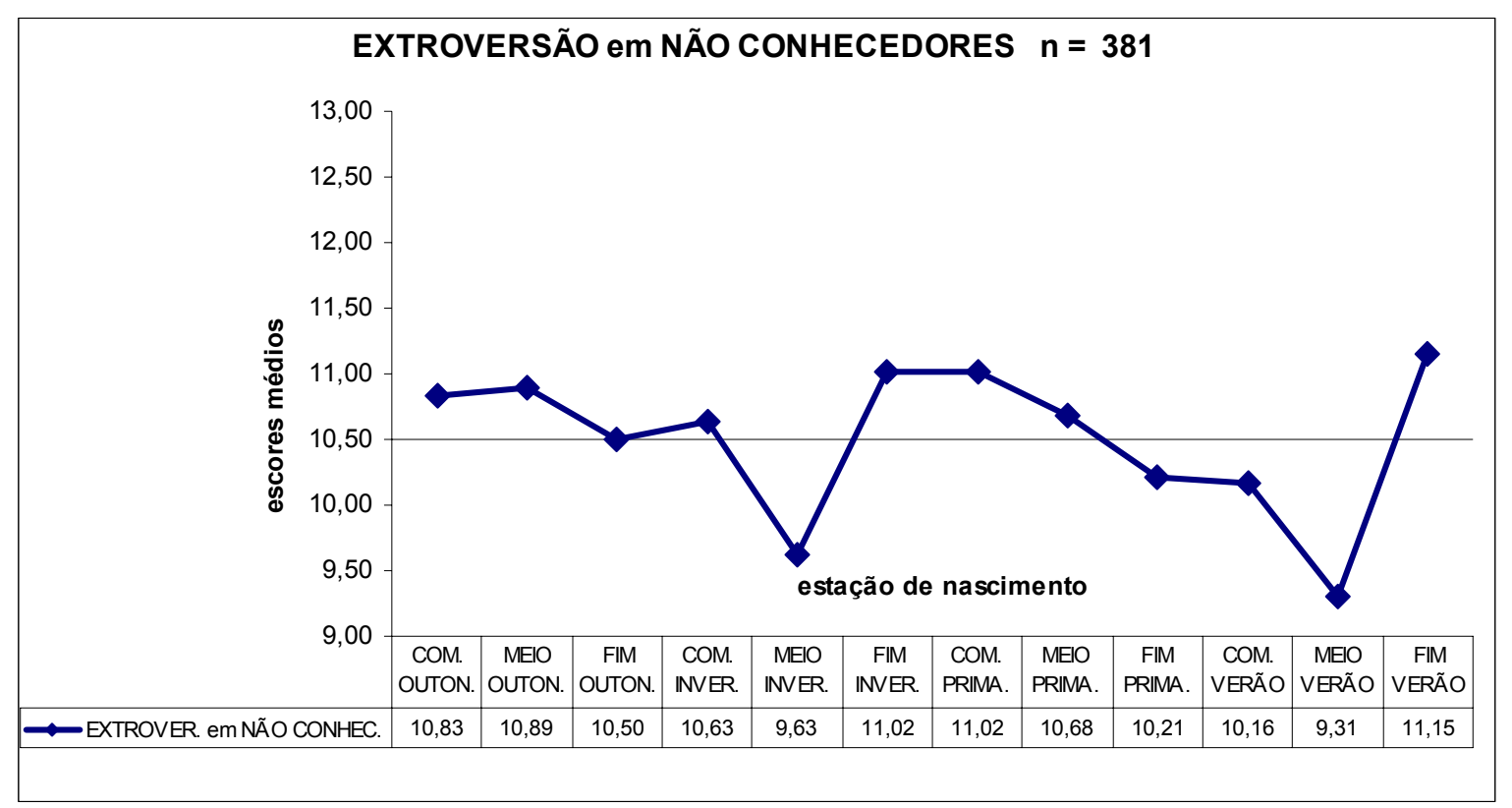

GRÁFICO IV

As Tabelas 7 e 8 indicam que não há significância na variação. A Extroversão, ao menos como é medida no $16 \mathrm{PF}$, parece não depender de nenhuma maneira de um fator sazonal ou astrológico entre os não conhecedores das características de seus signos.

Tabela 7: EXTROVERSÃO para grupo de não conhecedores RESUMO

\begin{tabular}{|l|r|r|r|r|}
\hline Grupo & \multicolumn{1}{|l|}{ Contagem } & \multicolumn{1}{l|}{ Soma } & \multicolumn{1}{l|}{ Média } & Variância \\
\hline SIGNOS ímpares & 179 & 1825,2 & 10,20 & 10,86 \\
\hline SIGNOS pares & 202 & 2170 & 10,74257 & 11,11029 \\
\hline
\end{tabular}

Tabela 8: ANOVA

\begin{tabular}{|l|r|r|r|r|r|r|}
\hline Fonte da variação & \multicolumn{1}{|l|}{$S Q$} & \multicolumn{1}{l|}{$g l$} & $M Q$ & $F$ & Valor $P$ & F crítico \\
\hline Entre grupos & 28,28442275 & 1 & 28,28442 & 2,57288 & 0,10954 & 3,86619 \\
\hline Dentro dos grupos & 4166,45985 & 379 & 10,99330 & & & \\
\hline$\Sigma$ & 4194,744273 & 380 & & & & \\
\hline
\end{tabular}




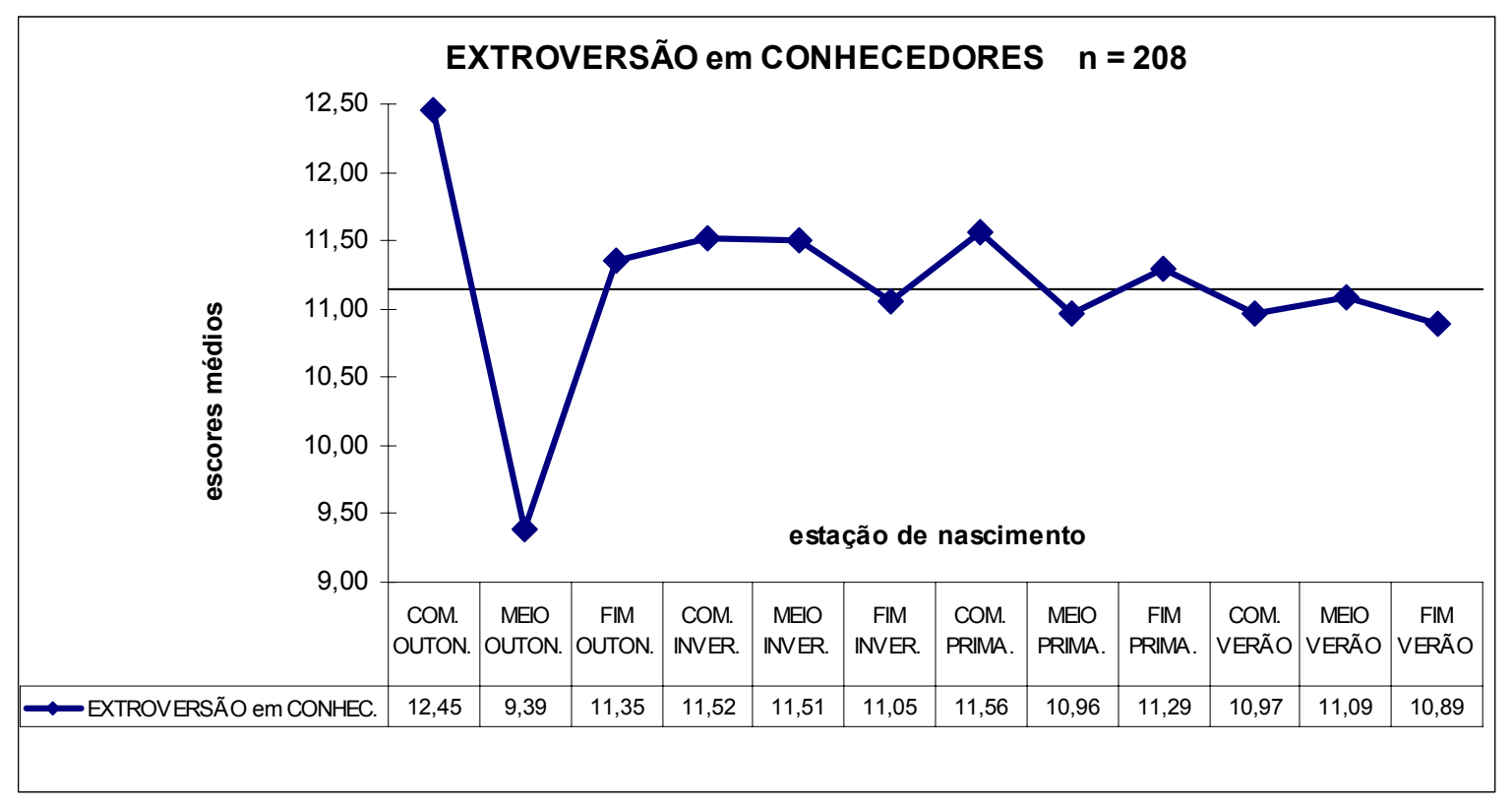

GRÁFICO V

Pode-se perceber que o conhecimento dos signos apenas levou a uma leve tendência do grupo a amoldar-se à predição astrológica, especialmente no período do Outono, como vemos no Gráfico V; mas aparentemente o padrão dente-de-serra foi comprimido. As Tabelas 9 e 10 expressam uma significação marginal para a diferenciação entre ímpares e pares, maior em comparação com a do grupo de não conhecedores.

Tabela 9: EXTROVERSÃO para grupo de conhecedores RESUMO

\begin{tabular}{|l|l|l|l|l|}
\hline Grupo & Contagem & Soma & Média & Variância \\
\hline SIGNOS ímpares & 96 & 1109,54 & 11,56 & 7,71 \\
\hline SIGNOS pares & 112 & 1218,76 & 10,88 & 9,29514 \\
\hline
\end{tabular}

Tabela 10: ANOVA

\begin{tabular}{|l|r|r|r|r|r|r|}
\hline Fonte da variação & \multicolumn{1}{|c|}{$S Q$} & gl & $M Q$ & $F$ & Valor $P$ & F crítico \\
\hline Entre grupos & 23,61671 & 1 & 23,61674 & 2,75777 & 0,09835 & 3,88700 \\
\hline Dentro dos grupos & 1764,1269 & 206 & 8,5637230 & & & \\
\hline$\Sigma$ & 1787,7436 & 207 & & & & \\
\hline
\end{tabular}


Mas confirmamos que o grupo de conhecedores da astrologia tem a média mais alta de Extroversão do que o grupo de não conhecedores, respectivamente 11,19 e 10,49. Ainda que a significância do resultado, $[\mathrm{F}=6,11, \mathrm{p}=0,01]$, não seja tão alta quanto a encontrada por Rooij et al. [F=8,09, $\mathrm{p}<0,005]$, a diferença se dá no mesmo sentido. Isto pode ser compreendido ao lembrarmos que a maioria dos sujeitos de Rooij et al. (331/500 $=66 \%)$ recebeu a sugestão Astrologia, enquanto em nosso caso foi uma minoria (266/589 $=45 \%)$. Assim podemos confirmar que a diferença entre as médias não seria apenas resultado do conhecimento da astrologia e crença em suas descrições nas respostas do questionário, mas antes a maior extroversão leva a maior probabilidade de conhecimento da astrologia. Nossos resultados apóiam esta hipótese, dado que há quase uma uniformidade de resultados entre os conhecedores. O Gráfico VI mostra esta diferenciação.

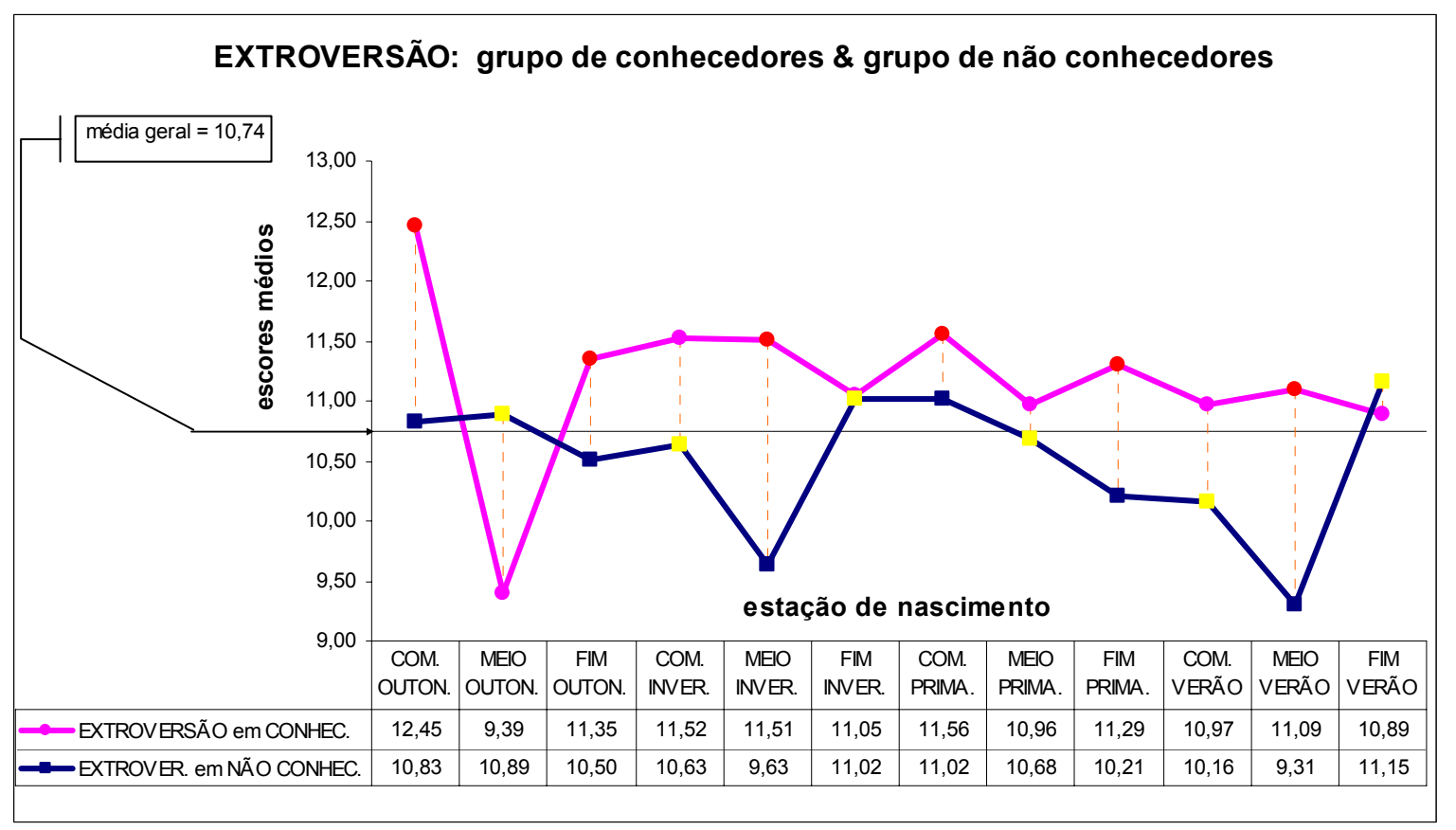

GRÁFICO VI 
Se a auto-atribuição de características astrológicas tivesse efeito uniforme determinaria entre os conhecedores um aumento das médias dos ímpares e uma diminuição - na mesma proporção - das médias dos pares, também por auto-atribuição, portanto a média no grupo de conhecedores continuaria muito próxima da média geral $(=$ $10,74)$, que por sua vez seria necessariamente acompanhada de perto pelas médias dos não conhecedores. Não ocorreu assim, o grupo de conhecedores divergiu significativamente da média geral.

E de fato podemos comprovar que seu distanciamento dos conhecedores para mais Extroversão em comparação aos não conhecedores deve-se exclusivamente ao subgrupo ímpar (Quente): O valor da média dos grupos de signos ímpares \& conhecedores $(11,56)$ tem diferença significativa estatisticamente $(t=3,44312, \mathrm{p}=0,0007)$ do valor da média dos ímpares \& não conhecedores $(10,20)$. A média do grupo de pares \& conhecedores $(10,88)$ não diverge significativamente $(t=0,36529, \mathrm{p}=0,72)$ da média dos pares $\&$ não conhecedores (10,74). A auto-atribuição funcionou de forma diferencial para a Extroversão, entre Frios e Quentes. Podemos observar pelo Gráfico VI que apenas a média do Meio do Outono entre os conhecedores fica abaixo da média geral, entre os signos pares deste grupo. ${ }^{44}$ A Extroversão não variou em dependência dos signos solares.

Avaliamos também os fatores componentes da Extroversão segundo a "equação de estimação", para verificar se algum deles divergiu significativamente dos resultados daquela, quer seja por permitir maior auto-atribuição, quer seja por apresentar maior divergência entre conhecedores e não conhecedores. Temos que a Expansividade e a Despreocupação foram diferenciadas significativamente para mais entre os conhecedores, como mostrado em seguida.

\footnotetext{
${ }^{44}$ Este padrão nítido do Outono repete-se regularmente em outros fatores, sua causa precisa ser mais bem estudada.
} 


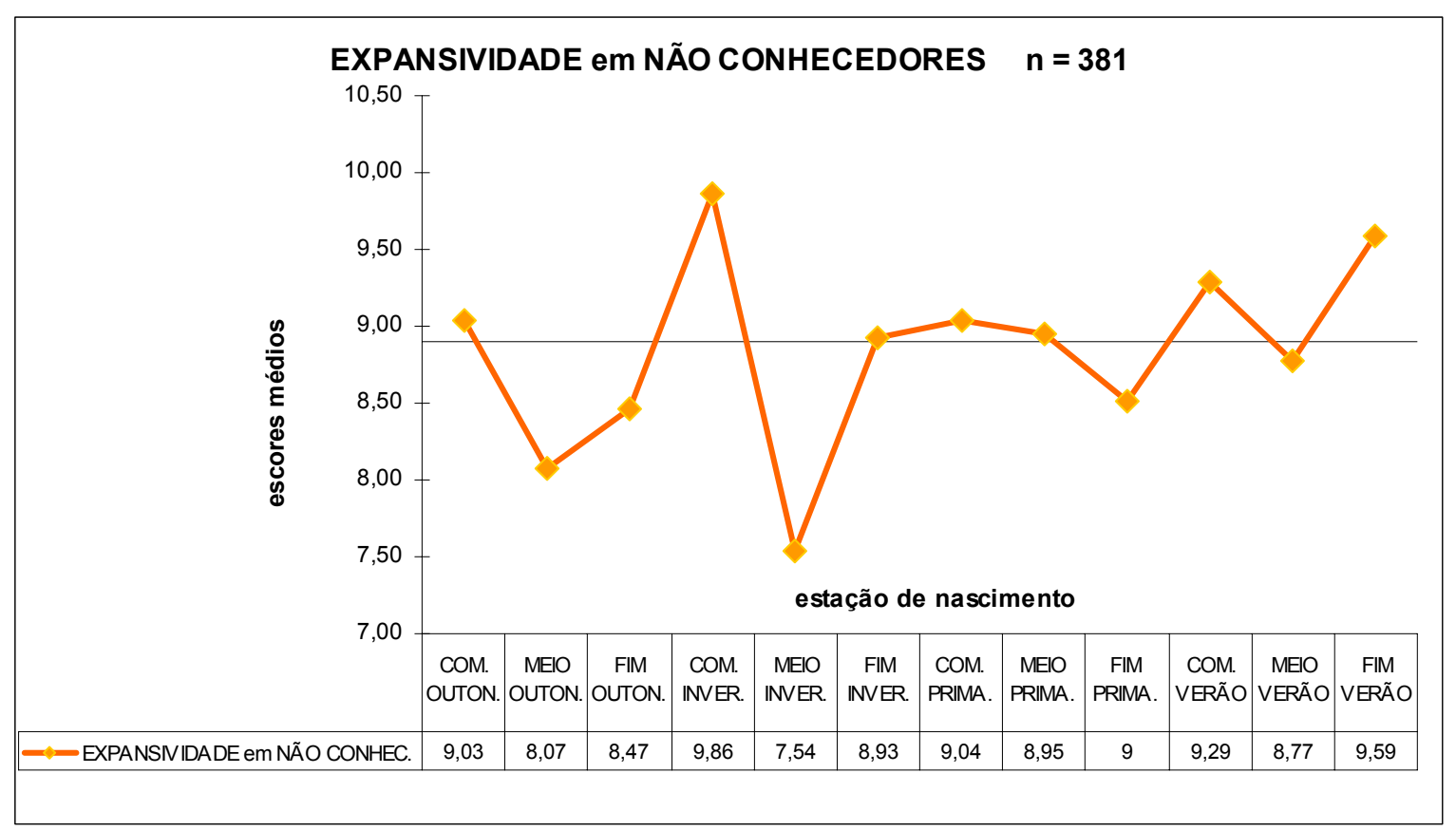

GRÁFICO VII

Temos no grupo dos não conhecedores um extremo para baixo no Meio do Inverno, como podemos ver no Gráfico VII, sugerindo um fator sazonal. Mas o extremo alto no Começo do Inverno quebra isto. Não há a variação astrológica, conforme vemos nas Tabelas 11 e 12; além disso, contrariando a predição astrológica, a média dos pares é mais alta do que a dos ímpares.

Tabela 11: EXPANSIVIDADE para grupo de não conhecedores RESUMO

\begin{tabular}{|l|r|r|r|l|}
\hline Grupo & Contagem & Soma & \multicolumn{1}{|l|}{ Média } & Variância \\
\hline SIGNOS ímpares & 179 & 1536 & 8,58 & 7,952670893 \\
\hline SIGNOS pares & 202 & 1844 & 9,13 & 9,266932663 \\
\hline
\end{tabular}

Tabela 12: ANOVA

\begin{tabular}{|l|l|r|l|l|r|r|}
\hline Fonte da variação & $S Q$ & $g l$ & $M Q$ & $F$ & Valor P & F crítico \\
\hline Entre grupos & 28,469278 & 1 & 28,46927839 & 3,291367653 & 0,07044 & 3,86611 \\
\hline Dentro dos grupos & 3278,2288 & 379 & 8,649680434 & & & \\
\hline$\Sigma$ & 3306,6981 & 380 & & & & \\
\hline
\end{tabular}




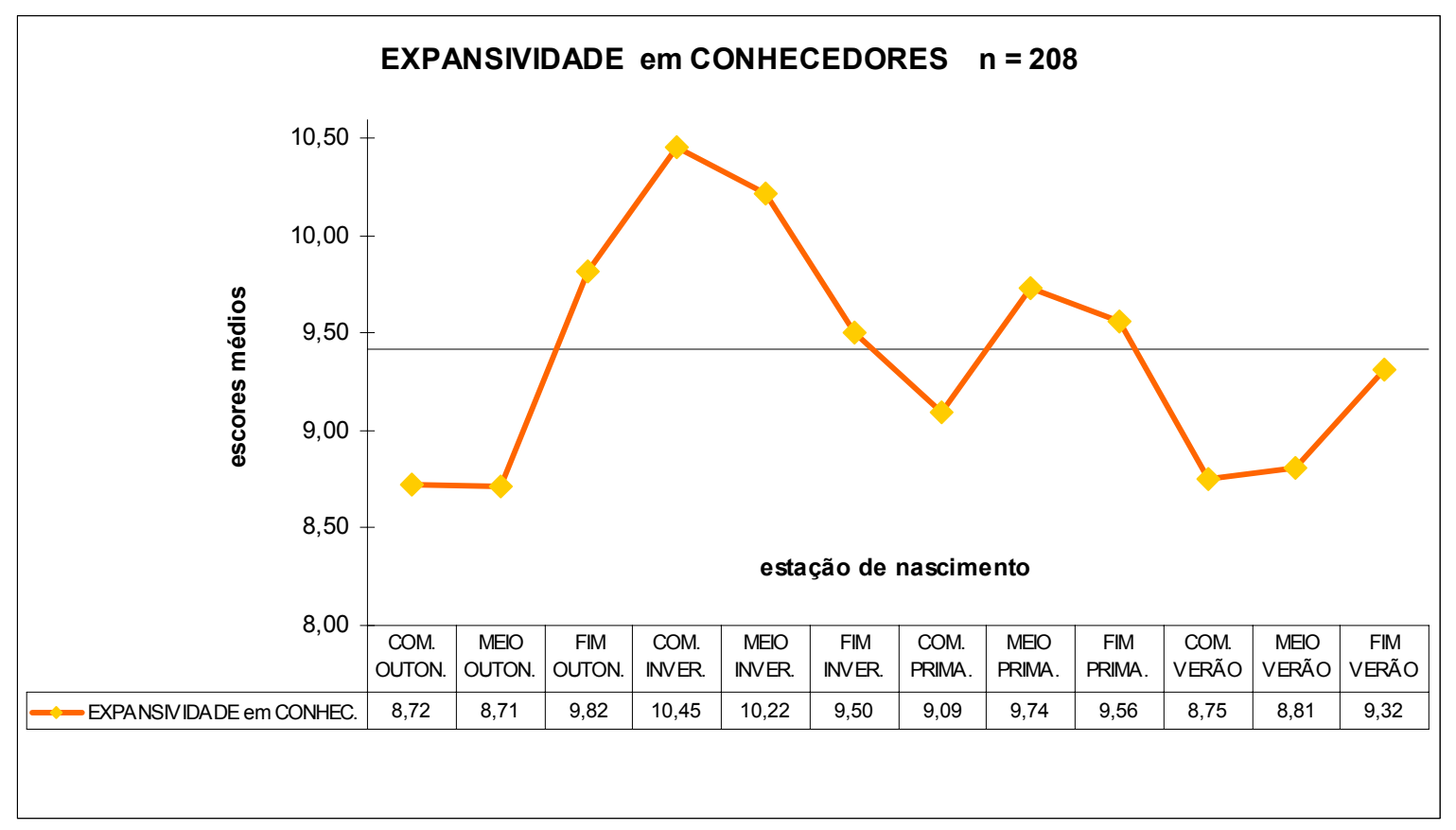

GRÁFICO VIII

Entre os conhecedores não há variação astrologicamente significativa na Expansividade, como vemos no Gráfico VIII e confirmamos nas Tabelas 13 e 14.

Tabela 13: EXPANSIVIDADE no grupo de conhecedores RESUMO

\begin{tabular}{|l|r|r|r|r|}
\hline Grupo & \multicolumn{1}{|l|}{ Contagem } & \multicolumn{1}{l|}{ Soma } & \multicolumn{1}{l|}{ Média } & Variância \\
\hline SIGNOS ímpares & 96 & 902 & 9,40 & 9,44167 \\
\hline SIGNOS pares & 112 & 1063 & 9,49 & 7,54947 \\
\hline
\end{tabular}

Tabela 14: ANOVA

\begin{tabular}{|l|r|r|r|r|r|r|}
\hline Fonte da variação & \multicolumn{1}{|l|}{$S Q$} & \multicolumn{1}{|l|}{ gl } & \multicolumn{1}{l|}{ MQ } & F & Valor P & F crítico \\
\hline Entre grupos & 0,46886 & 1 & 0,46886 & 0,05567 & 0,81371 & 3,88700 \\
\hline Dentro dos grupos & 1734,9494 & 206 & 8,42208 & & & \\
\hline$\Sigma$ & 1735,4183 & 207 & & & & \\
\hline
\end{tabular}

Já a média em Expansividade no grupo de conhecedores $(=9,45)$ é significativamente maior $(t=2,27858, \mathrm{p}=0,023)$ do que a média do grupo de não conhecedores $(=8,90)$, contribuindo para a Extroversão maior entre os primeiros. 


\subsubsection{DESPREOCUPAÇÃO PARA GRUPO DE NÃO CONHECEDORES}

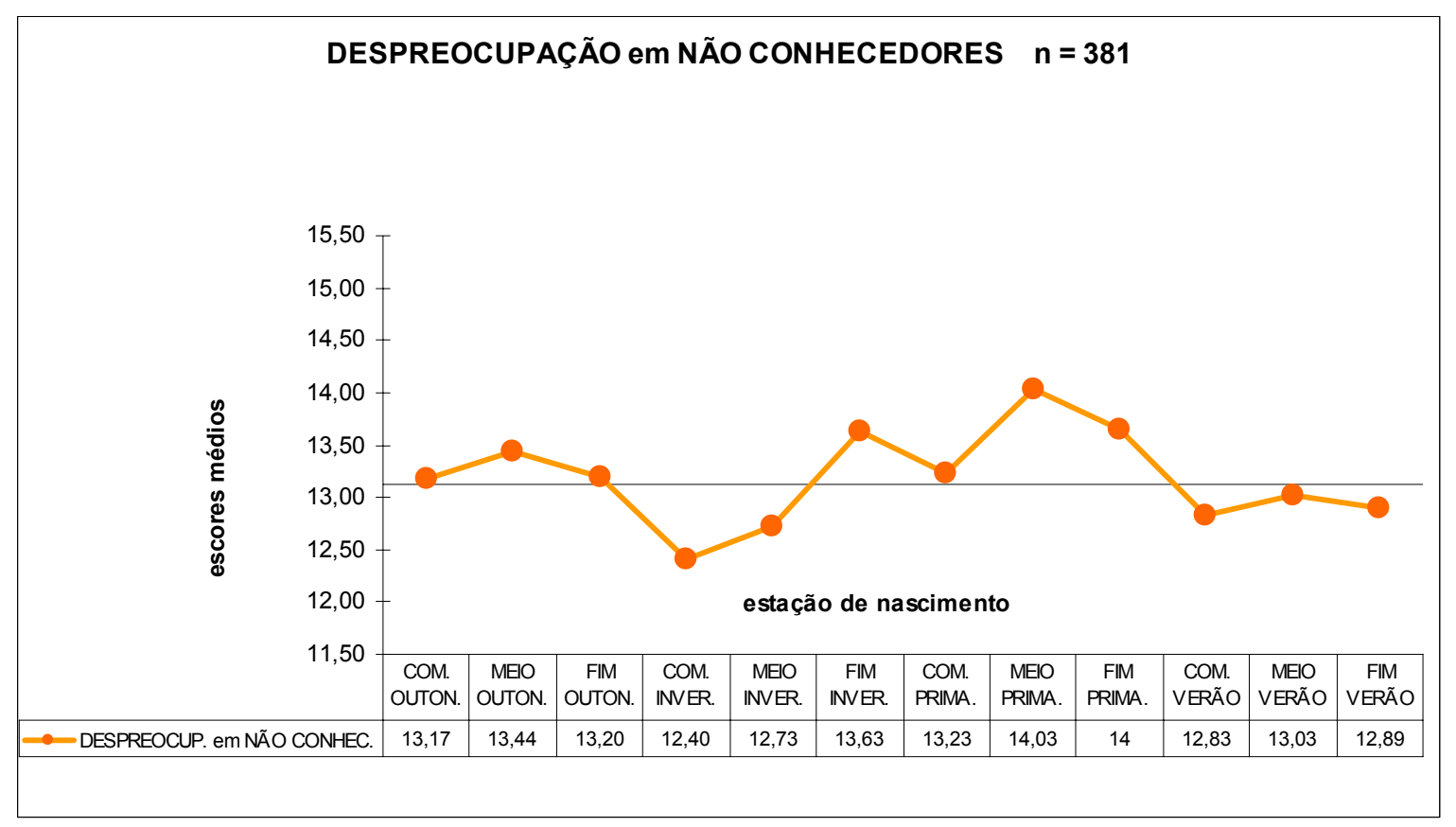

GRÁFICO IX

Ao avaliarmos os resultados da Despreocupação para o grupo de não conhecedores, temos apenas um esboço do padrão em torno do Começo do Inverno e do Começo do Verão, como vemos no Gráfico IX, e se confirma na falta de significância do padrão nas Tabelas 15 e 16. A diferença não é significante, ou seja, a variância entre os grupos é muito menor que aquela de dentro dos grupos.

Tabela 15: DESPREOCUPAÇÃO para grupo de não conhecedores RESUMO

\begin{tabular}{|l|r|r|r|r|}
\hline Grupo & Contagem & Soma & \multicolumn{1}{|l|}{ Média } & Variância \\
\hline SIGNOS ímpares & 179 & 2357 & 13,17 & 14,46614 \\
\hline SIGNOS pares & 202 & 2672 & 13,23 & 14,73395 \\
\hline
\end{tabular}

Tabela 16: ANOVA

\begin{tabular}{|l|r|r|r|r|r|r|}
\hline Fonte da variação & \multicolumn{1}{l|}{$S Q$} & \multicolumn{1}{l|}{ gl } & \multicolumn{1}{l|}{ MQ } & $F$ & Valor P & F crítico \\
\hline Entre grupos & 0,34308 & 1 & 0,34308 & 0,02349 & 0,87828 & 3,86612 \\
\hline Dentro dos grupos & 5536,4968 & 379 & 14,60817 & & & \\
\hline$\Sigma$ & 5536,8399 & 380 & & & & \\
\hline
\end{tabular}




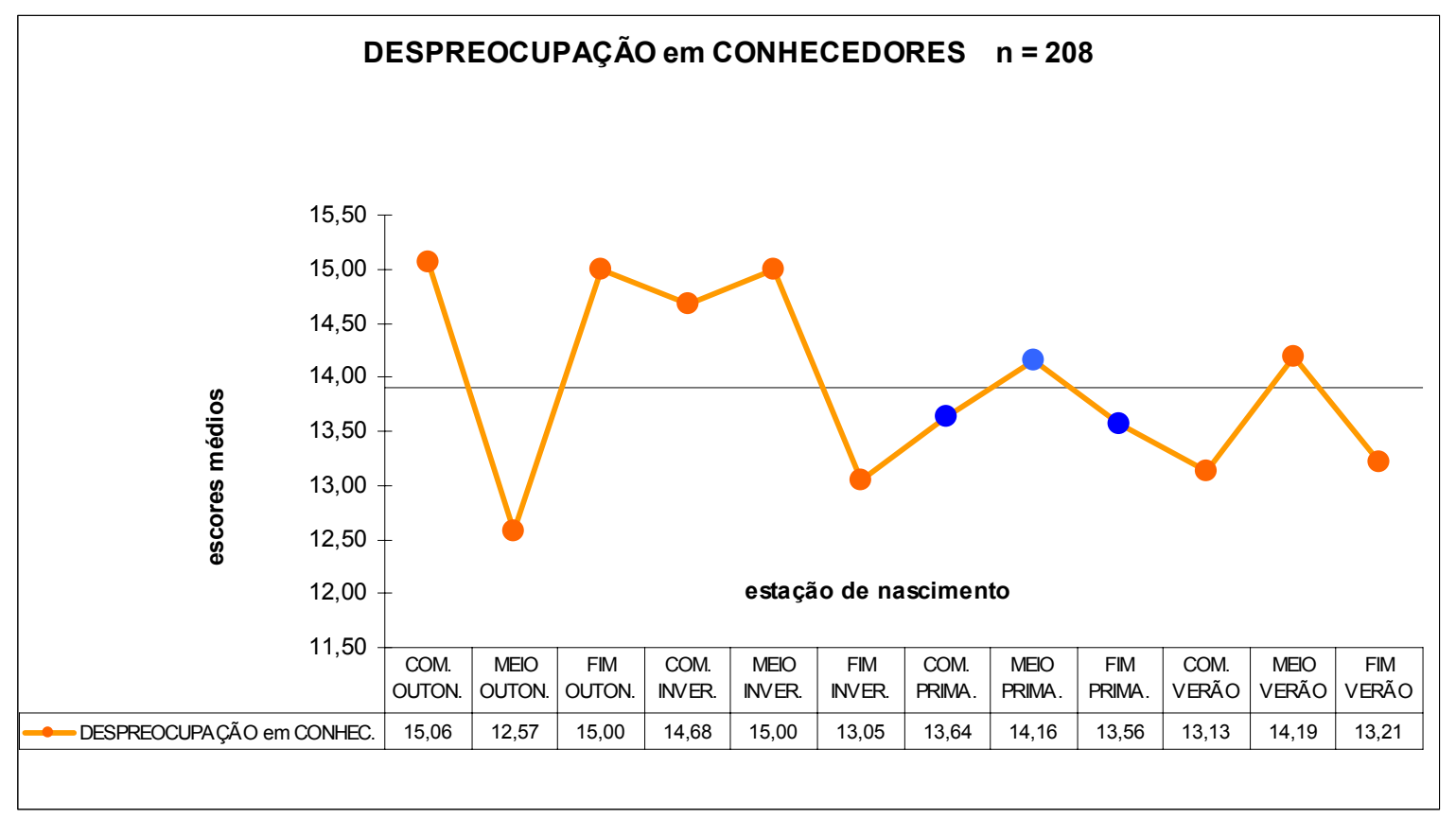

GRÁFICO X

O Gráfico X mostra apenas levemente a tendência da Despreocupação a seguir o padrão dente-de-serra, entre os conhecedores, com a inversão do padrão durante toda a Primavera. As Tabelas 17 e 18 demonstram a significação marginal dos resultados para a hipótese astrológica, mesmo nos que conhecem astrologia.

Tabela 17: DESPREOCUPAÇÃO no grupo de conhecedores RESUMO

\begin{tabular}{|l|r|r|r|c|}
\hline Grupo & \multicolumn{1}{|l|}{ Contagem } & \multicolumn{1}{l|}{ Soma } & \multicolumn{1}{l|}{ Média } & Variância \\
\hline SIGNOS ímpares & 96 & 1390 & 14,48 & 11,01009 \\
\hline SIGNOS pares & 112 & 1516 & 13,54 & 13,06178 \\
\hline
\end{tabular}

Tabela 18: ANOVA

\begin{tabular}{|l|r|r|r|r|r|r|}
\hline Fonte da variação & \multicolumn{1}{|l|}{$S Q$} & gl & $M Q$ & $F$ & Valor P & F crítico \\
\hline Entre grupos & 46,01145 & 1 & 46,01145 & 3,79770 & 0,05268 & 3,88700 \\
\hline Dentro dos grupos & 2495,8155 & 206 & 12,11561 & & & \\
\hline$\Sigma$ & 2542,8270 & 207 & & & & \\
\hline
\end{tabular}


Apenas podemos confirmar que também a média em Despreocupação no grupo de conhecedores é significativamente maior do que a média do grupo de não conhecedores, respectivamente 13,97 e $13,20(t=2,41280, \mathrm{p}=0,016)$.

Avaliamos em seguida a Inteligência, para verificar se tem uma variação de base astrológica, se própria ou se dependente de um Fator de segunda ordem. 


\subsubsection{INTELIGÊNCIA NO GRUPO DE NÃO CONHECEDORES DA ASTROLOGIA}

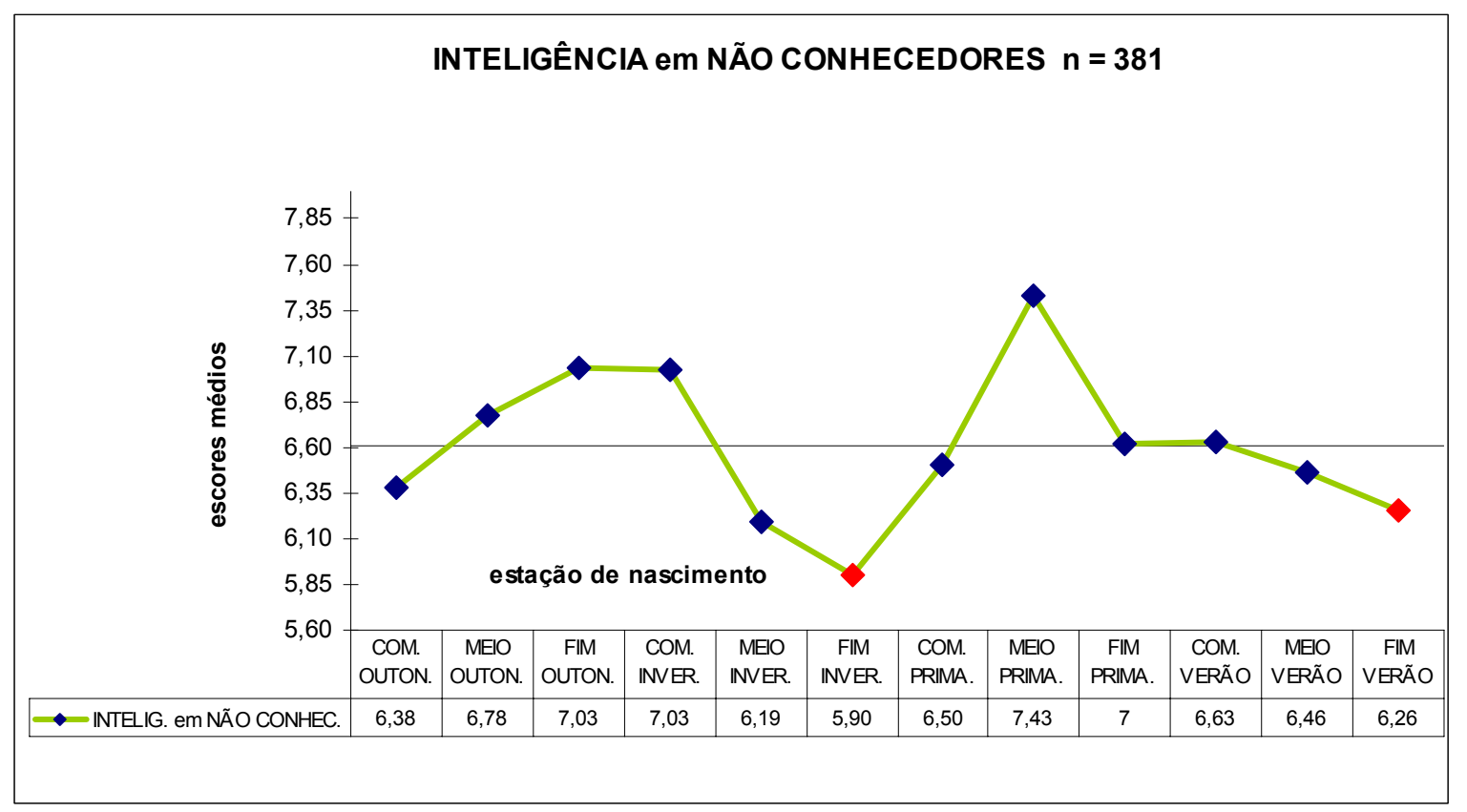

GRÁFICO XI

$\mathrm{Na}$ análise da variância descrita nas Tabelas 19 e 20 podemos observar que não há uma adequação dos resultados à divisão par-ímpar no grupo de não conhecedores. Os resultados dos grupos do Fim do Inverno e do Fim do Verão, entre os signos pares, abaixo da média como vemos no Gráfico XI, poderiam ter explicação em função da característica astrológica de "mutabilidade" compartilhada por estes. Porém o grupo do Começo do Verão fica na média, e aquele do Começo do Inverno fica acima da média, quebrando qualquer influência dos Ritmos astrológicos.

Tabela 19: INTELIGÊNCIA para grupo de não conhecedores

\begin{tabular}{|l|r|r|r|r|}
\hline Grupo & Contagem & Soma & Média & Variância \\
\hline SIGNOS ímpares & 179 & 1170 & 6,54 & 3,14895 \\
\hline SIGNOS pares & 202 & 1347 & 6,67 & 3,77501 \\
\hline
\end{tabular}

Tabela 20: ANOVA

\begin{tabular}{|l|r|r|r|r|r|r|}
\hline Fonte da variação & \multicolumn{1}{l|}{$S Q$} & \multicolumn{1}{l|}{$g l$} & \multicolumn{1}{l|}{$M Q$} & $F$ & Valor $P$ & F crítico \\
\hline Entre grupos & 1,65369 & 1 & 1,65369 & 0,47506 & 0,49109 & 3,86612 \\
\hline Dentro dos grupos & 1319,2912 & 379 & 3,48098 & & & \\
\hline$\Sigma$ & 1320,9449 & 380 & & & & \\
\hline
\end{tabular}




\subsubsection{INTELIGENNCIA NO GRUPO DE CONHECEDORES DA ASTROLOGIA}

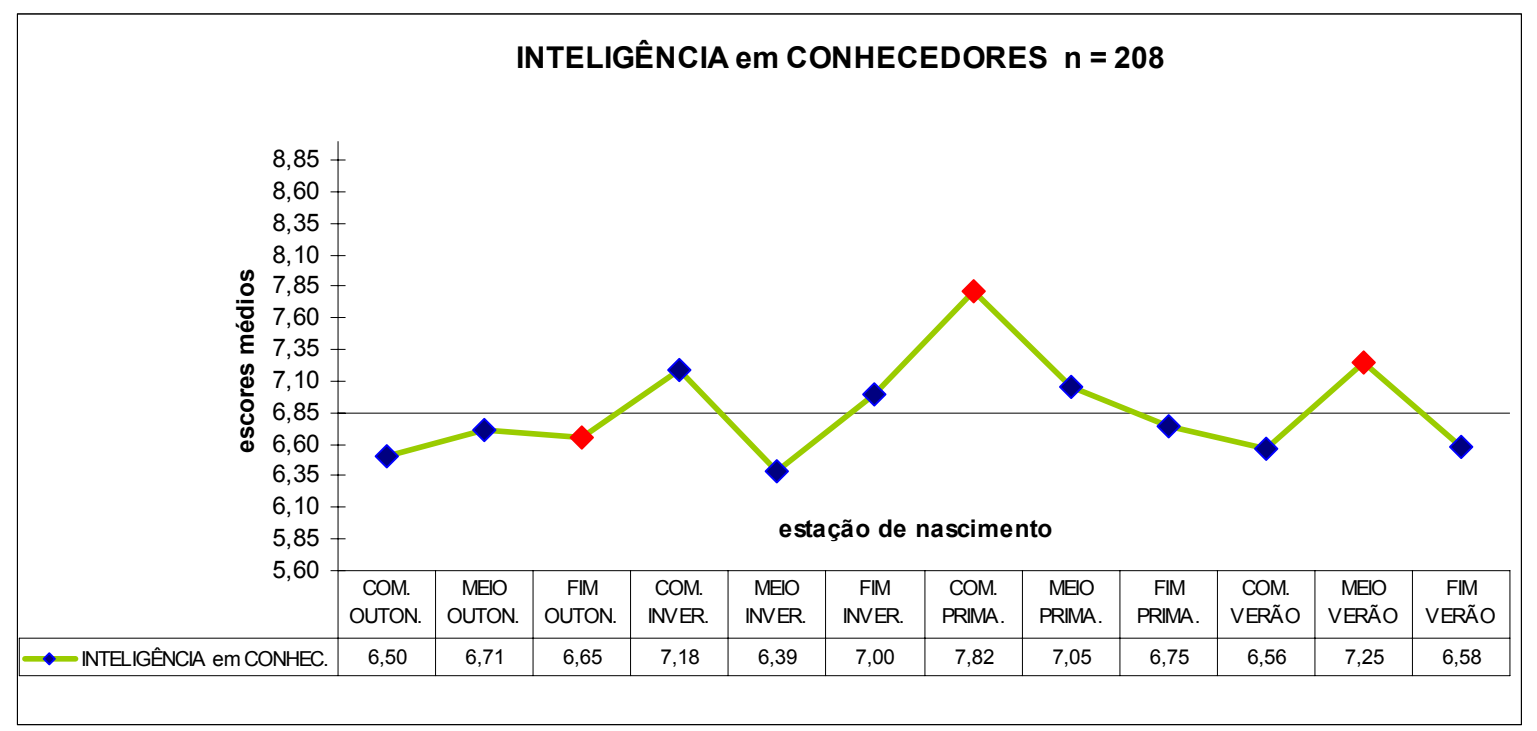

GRÁFICO XII

Provavelmente o conhecimento da astrologia leva a um aumento relativo das médias entre os ímpares relacionados ao elemento Ar, porque o Ar é tradicionalmente relacionado à intelectualidade na astrologia (PARKER, PARKER, 1982). Podemos ver isto no Gráfico XII, com os grupos marcados em vermelho. As Tabelas 21 e 22 mostram pela análise da variância que não há regularidade de alternância, e que a média geral dos ímpares não fica acima daquela dos pares, talvez a auto-atribuição de origem astrológica aumentou os resultados em Inteligência apenas para aqueles dos signos do Ar.

Tabela 21: INTELIGÊNCIA para grupo de conhecedores RESUMO

\begin{tabular}{|l|r|r|r|r|}
\hline Grupo & \multicolumn{1}{|l|}{ Contagem } & \multicolumn{1}{|l|}{ Soma } & \multicolumn{1}{l|}{ Média } & Variância \\
\hline SIGNOS ímpares & 96 & 655 & 6,82 & 4,08410 \\
\hline SIGNOS pares & 112 & 770 & 6,88 & 3,51577 \\
\hline
\end{tabular}

Tabela 22: ANOVA

\begin{tabular}{|l|r|r|r|r|r|r|}
\hline Fonte da variação & \multicolumn{1}{|l|}{$S Q$} & \multicolumn{1}{l|}{ gl } & \multicolumn{1}{l|}{ MQ } & \multicolumn{1}{l|}{ F } & \multicolumn{1}{l|}{ Valor $P$} & F crítico \\
\hline Entre grupos & 0,1402 & 1 & 0,14022 & 0,03712 & 0,84742 & 3,88700 \\
\hline Dentro dos grupos & 778,2395 & 206 & 3,77786 & & & \\
\hline$\Sigma$ & 778,3798 & 207 & & & & \\
\hline
\end{tabular}


Avaliamos a Autodisciplina, que, além de ter variado conjuntamente à Inteligência na amostra da nossa Dissertação (1997), é fator componente tanto do Controle $(+)$ quanto da Ansiedade (-).

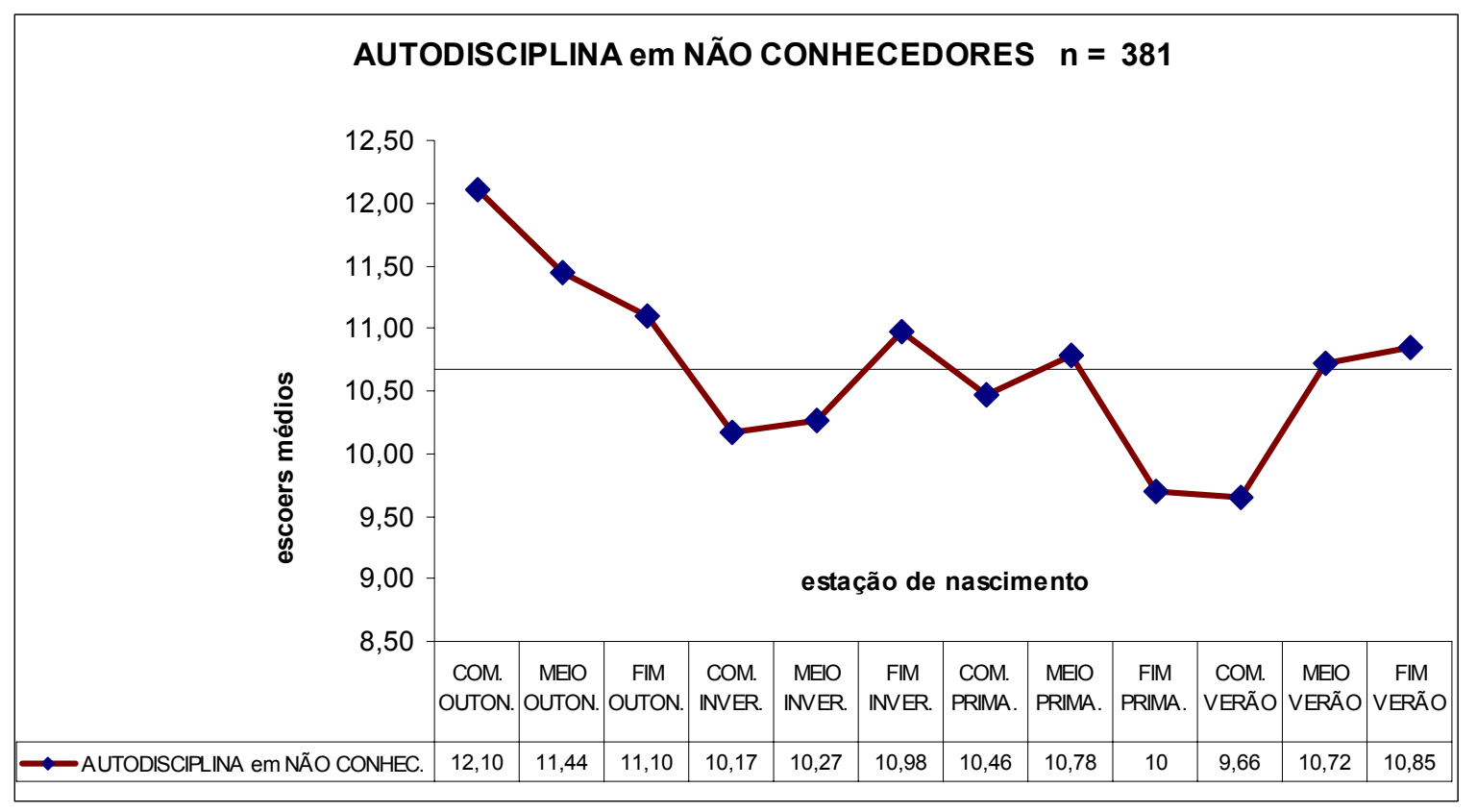

GRÁFICO XIII

$\mathrm{Na}$ análise dos resultados para o grupo de não conhecedores percebemos que há a falta de qualquer padrão reconhecível, com vemos no Gráfico XIII, e a diferença entre ímpares e pares praticamente não existe, como se comprova nas Tabelas 23 e 24 . Portanto se há alguma variação regular esta se deverá ao conhecimento em astrologia, e é o que avaliamos no grupo seguinte.

Tabela 23: AUTODISCIPLINA para grupo de não conhecedores RESUMO

\begin{tabular}{|l|r|r|r|r|}
\hline Grupo & \multicolumn{1}{|c|}{ Contagem } & \multicolumn{1}{l|}{ Soma } & \multicolumn{1}{l|}{ Média } & Variância \\
\hline SIGNOS ímpares & 179 & 1922 & 10,74 & 8,90258 \\
\hline SIGNOS pares & 202 & 2145 & 10,62 & 8,53556 \\
\hline
\end{tabular}


Tabela 24: ANOVA

\begin{tabular}{|c|c|c|c|c|c|c|}
\hline Fonte da variação & $S Q$ & $g l$ & $M Q$ & $F$ & Valor P & F crítico \\
\hline Entre grupos & 1,33531 & 1 & 1,33531 & 0,15334 & 0,69558 & 3,86612 \\
\hline Dentro dos grupos & 3300,30773 & 379 & 8,70794 & & & \\
\hline$\Sigma$ & 3301,6430 & 380 & & & & \\
\hline
\end{tabular}




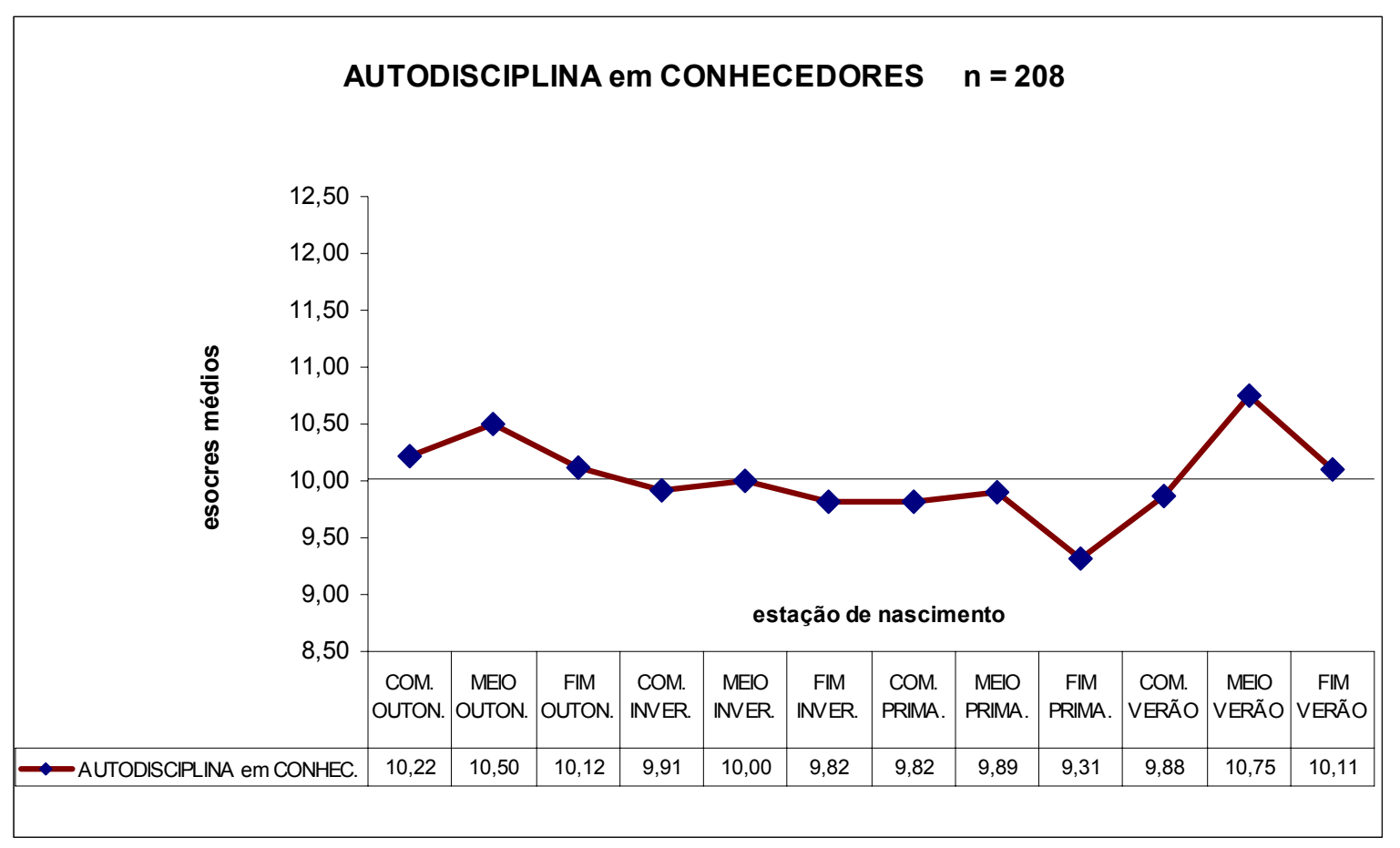

GRÁFICO XIV

Com o grupo de conhecedores também não há variação significativa entre ímpares e pares na Autodisciplina, como demonstra a análise de variância nas Tabelas 25 e 26, e não há padrão astrológico ou sazonal, com podemos observar pelo Gráfico XIV.

Tabela 25: AUTODISCIPLINA para grupo de conhecedores RESUMO

\begin{tabular}{|l|r|r|r|r|}
\hline Grupo & \multicolumn{1}{|l|}{ Contagem } & \multicolumn{1}{l|}{ Soma } & Média & Variância \\
\hline SIGNOS ímpares & 96 & 965 & 10,05 & 8,44989 \\
\hline SIGNOS pares & 112 & 1119 & 9,99 & 7,48641 \\
\hline
\end{tabular}

Tabela 26: ANOVA

\begin{tabular}{|l|r|r|r|r|r|r|}
\hline Fonte da variação & \multicolumn{1}{|l|}{ SQ } & gl & MQ & F & Valor P & F crítico \\
\hline Entre grupos & 0,19242 & 1 & 0,19242 & 0,02426 & 0,87637 & 3,88700 \\
\hline Dentro dos grupos & 1633,73065 & 206 & 7,93073 & & & \\
\hline$\Sigma$ & 1633,9231 & 207 & & & & \\
\hline
\end{tabular}


Apenas podemos confirmar que há uma diferença significativa $(t=-2,62140, \mathrm{p}=$ $0,009)$ entre as médias de Autodisciplina entre os conhecedores $(=10,02)$ e os não conhecedores $(=10,67)$.

O fato de os não conhecedores terem média mais alta em Autodisciplina, o que podemos ver no Gráfico XV, aponta para uma provável diferença na relação com o mundo externo, em que estes se apóiam mais em suas capacidades e menos em contingências externas para a busca de suas realizações, enquanto os conhecedores acreditariam mais em determinações externas para suas vidas, daí o conhecimento da astrologia que buscam.

A avaliação seguinte da Ansiedade permitirá discriminar se a variação significativa da Autodisciplina encontrada na Dissertação (RODRIGUES, 1997) foi um resultado espúrio ou foi decorrência da influência da Ansiedade, tanto na Inteligência quanto na Autodisciplina.

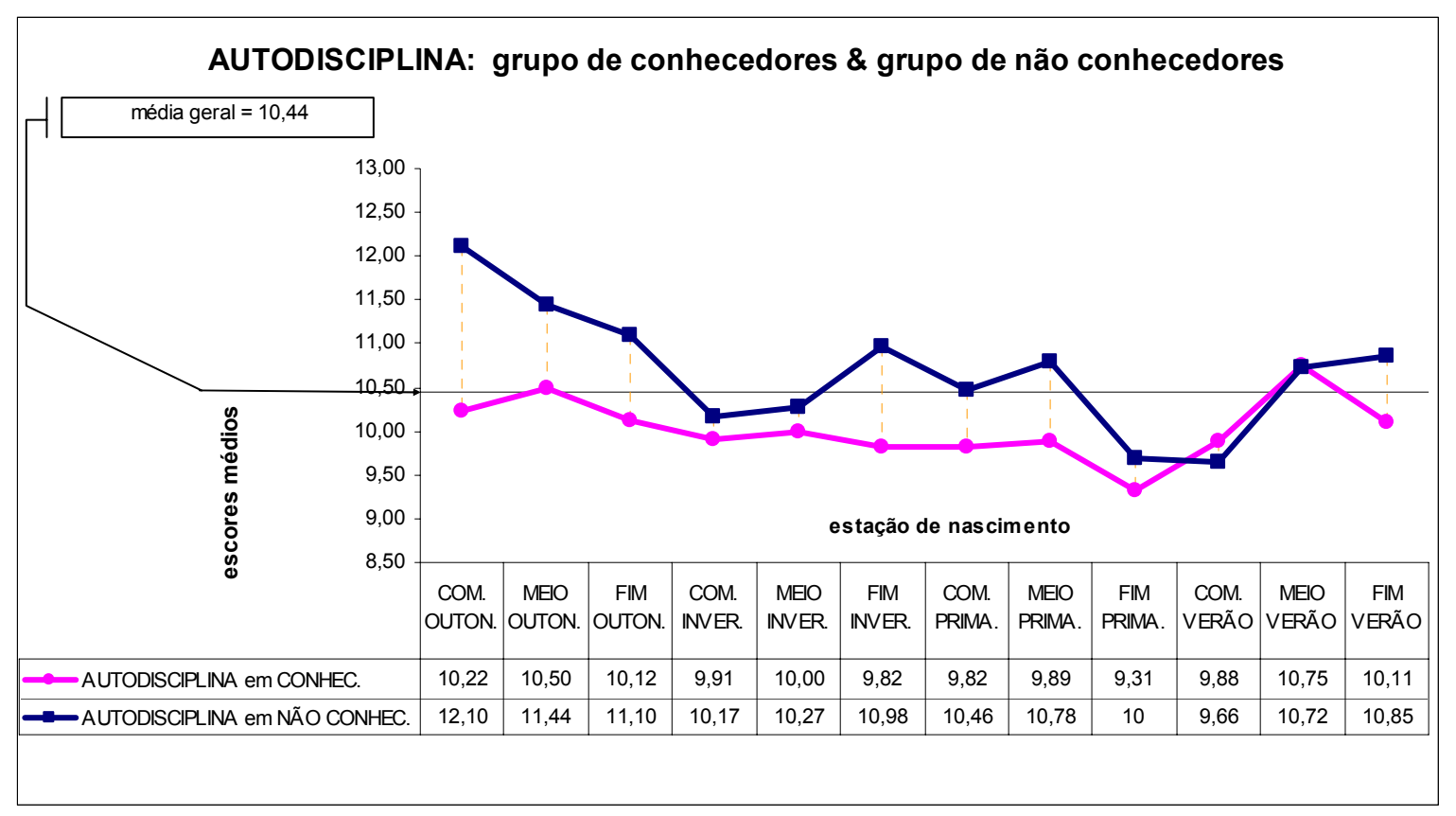

GRÁFICO XV 


\subsubsection{ANSIEDADE NO GRUPO DE NÃO CONHECEDORES}

Avaliar o Fator de segunda ordem Ansiedade leva a resultados mais confiáveis, pois é composto de seis Fatores ${ }^{45}$, sendo um deles (Desenvoltura) em comum (-) com Extroversão, e outro (Autodisciplina) em comum (-) com o Controle.

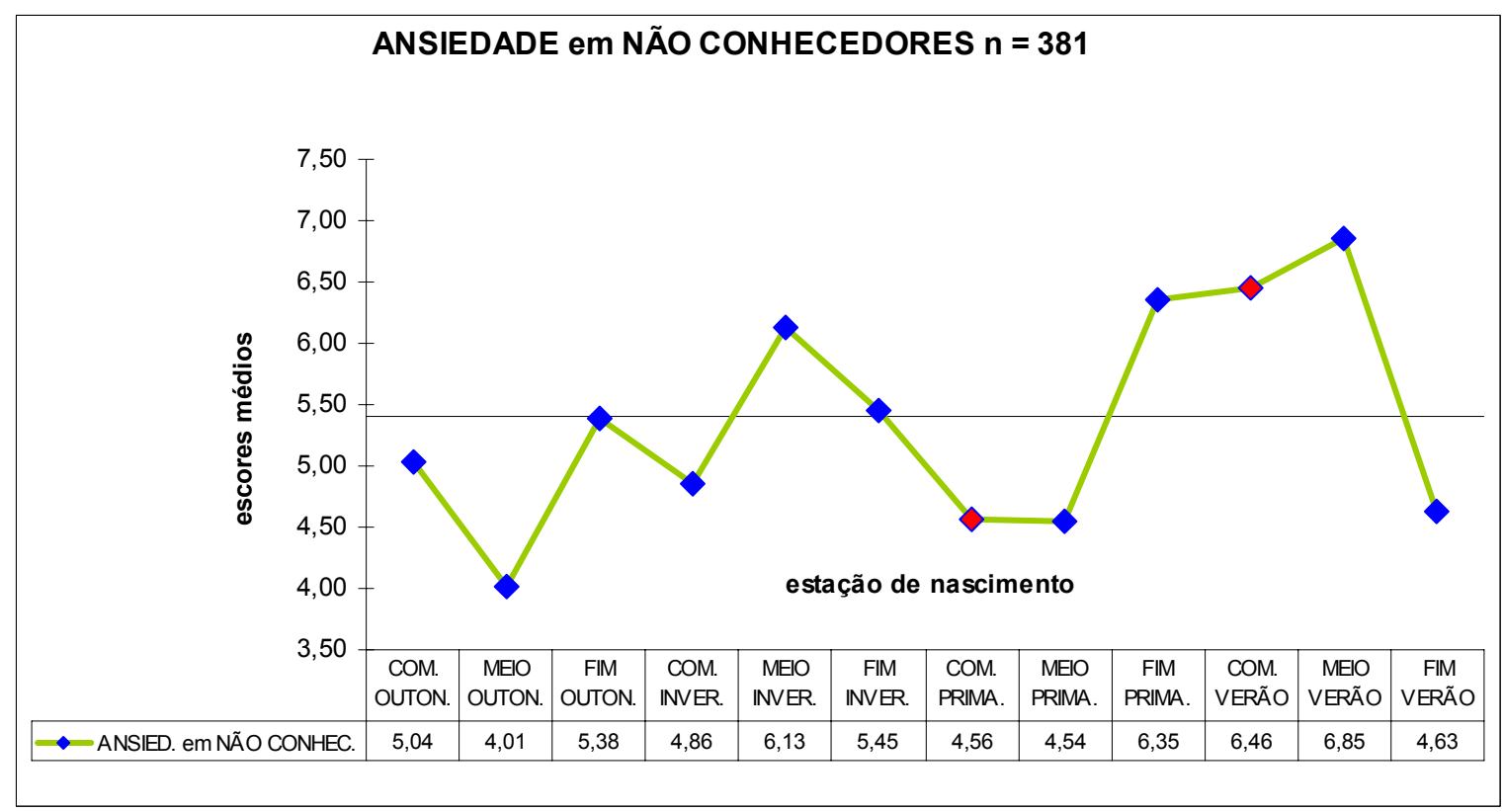

GRÁFICO XVI

No grupo de não conhecedores obtivemos aproximação ao padrão dente-de-serra, o Gráfico XVI pode confirmar isto, com as exceções do Começo da Primavera e do Começo do Verão. A ANOVA também revela esta diferença significativa entre impares e pares, como se lê nas Tabelas 27 e 28 .

\footnotetext{
${ }^{45}$ É medida através de 72 itens.
} 
Tabela 27: ANSIEDADE para grupo de não conhecedores RESUMO

\begin{tabular}{|l|r|r|r|r|}
\hline Grupo & Contagem & \multicolumn{1}{|l|}{ Soma } & \multicolumn{1}{|c|}{ Média } & Variância \\
\hline SIGNOS ímpares & 179 & 1036,78 & 5,79 & 13,25780 \\
\hline SIGNOS pares & 202 & 1021,26 & 5,06 & 11,74727 \\
\hline
\end{tabular}

Tabela 28: ANOVA

\begin{tabular}{|l|r|r|r|r|r|r|}
\hline Fonte da variação & \multicolumn{1}{|l|}{$S Q$} & $g l$ & $M Q$ & $F$ & Valor $P$ & F crítico \\
\hline Entre grupos & 51,45385 & 1 & 51,45385 & 4,13062 & 0,04281 & 3,86612 \\
\hline Dentro dos grupos & 4721,0905 & 379 & 12,45670 & & & \\
\hline$\Sigma$ & 4772,5443 & 380 & & & & \\
\hline
\end{tabular}




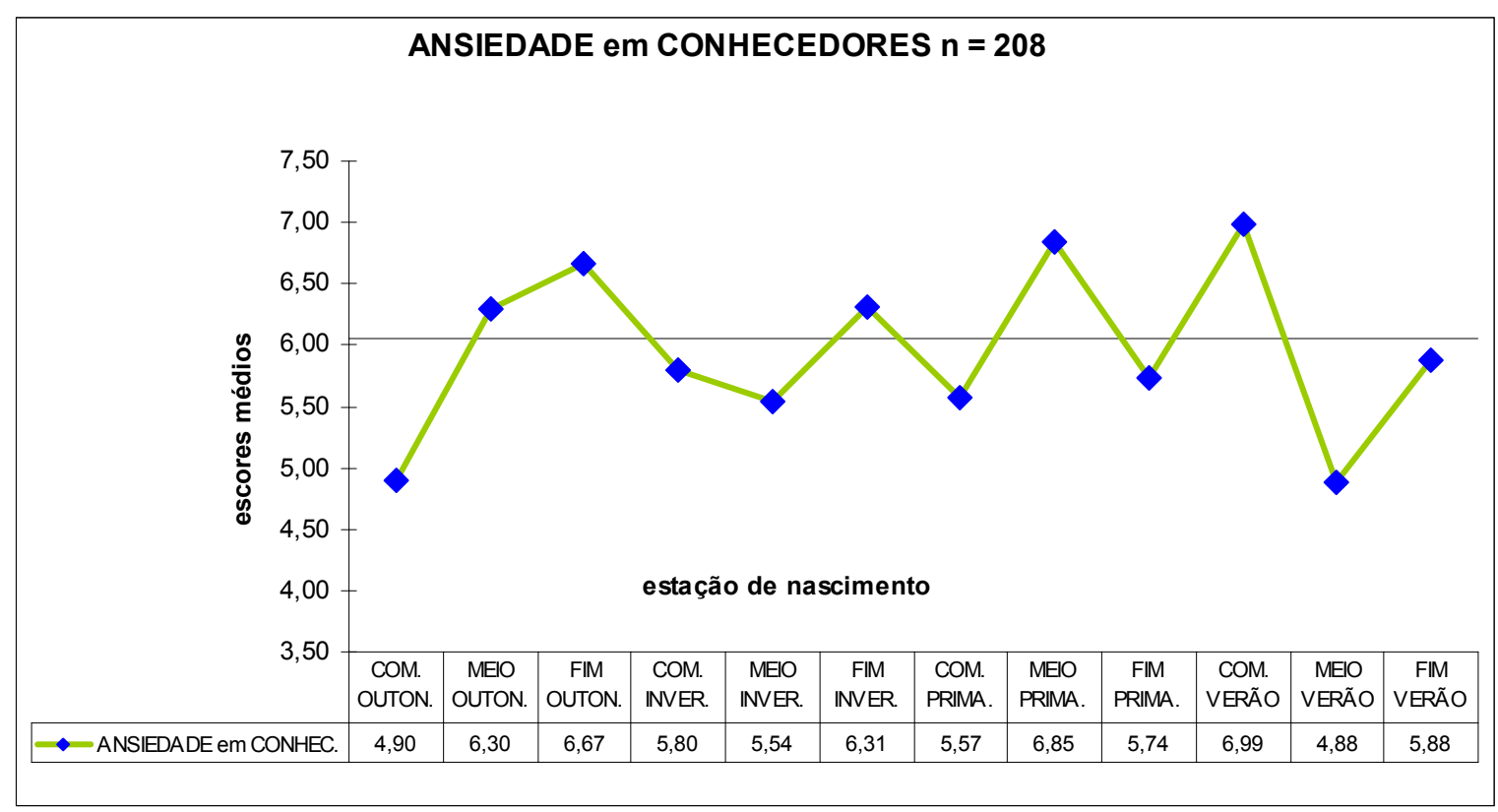

GRÁFICO XVII

Para o grupo de conhecedores a Ansiedade é mostrada no Gráfico XVII. Não há diferenças significativa entre ímpares e pares, como se lê nas Tabelas 29 e 30. A tendência que ocorre no caso dos conhecedores é a de que os signos ímpares fiquem abaixo da média, ao contrário do grupo dos não conhecedores. 
Tabela 29: ANSIEDADE para grupo de conhecedores

RESUMO

\begin{tabular}{|l|r|r|r|r|}
\hline Grupo & Contagem & \multicolumn{1}{l|}{ Soma } & \multicolumn{1}{l|}{ Média } & Variância \\
\hline SIGNOS ímpares & 96 & 532,52 & 5,55 & 11,61168 \\
\hline SIGNOS pares & 112 & 708,2 & 6,32 & 11,93625 \\
\hline
\end{tabular}

Tabela 30: ANOVA

\begin{tabular}{|l|r|r|r|r|r|r|}
\hline Fonte da variação & \multicolumn{1}{|l|}{$S Q$} & \multicolumn{1}{|l|}{$g l$} & $M Q$ & $F$ & Valor $P$ & F crítico \\
\hline Entre grupos & 31,13837 & 1 & 31,13837 & 2,64185 & 0,10561 & 3,88700 \\
\hline Dentro dos grupos & 2428,0338 & 206 & 11,78657 & & & \\
\hline$\Sigma$ & 2459,1722 & 207 & & & & \\
\hline
\end{tabular}

Também obtivemos diferença marginalmente significativa $(t=1,86161, \mathrm{p}=0,063)$ para a Ansiedade entre a média dos conhecedores $(=5,97)$ e a dos não conhecedores $(=$ 5,40), conforme visto no Gráfico XVIII. A média para os primeiros, ligeiramente mais alta, apóia a hipótese de que é um grupo que utiliza-se da astrologia como meio de lidar com ansiedades. Com a análise dos fatores componentes da Ansiedade, em seguida, podemos discriminar se há algum fator mais específico relacionado à busca do conhecimento astrológico.

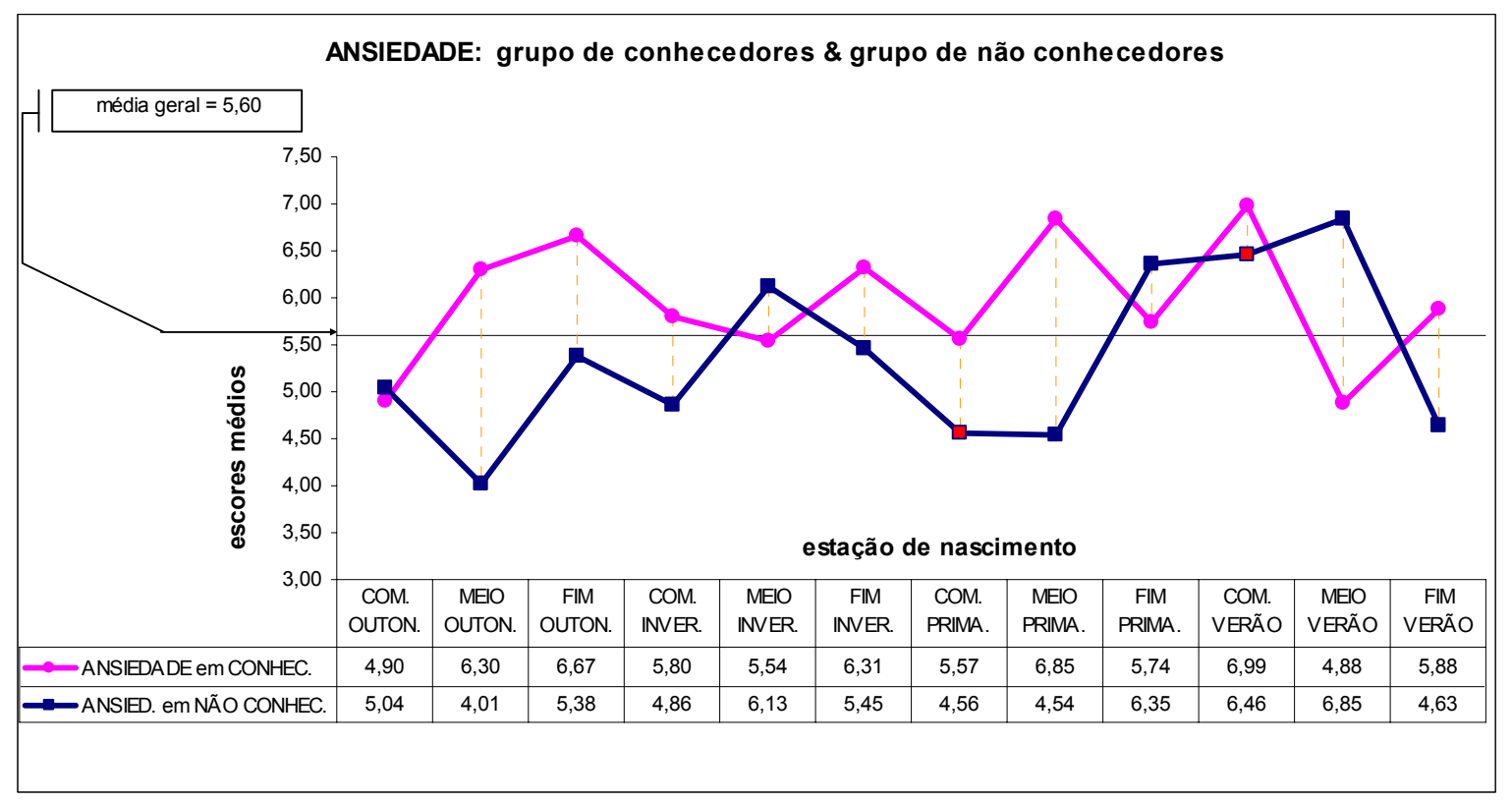




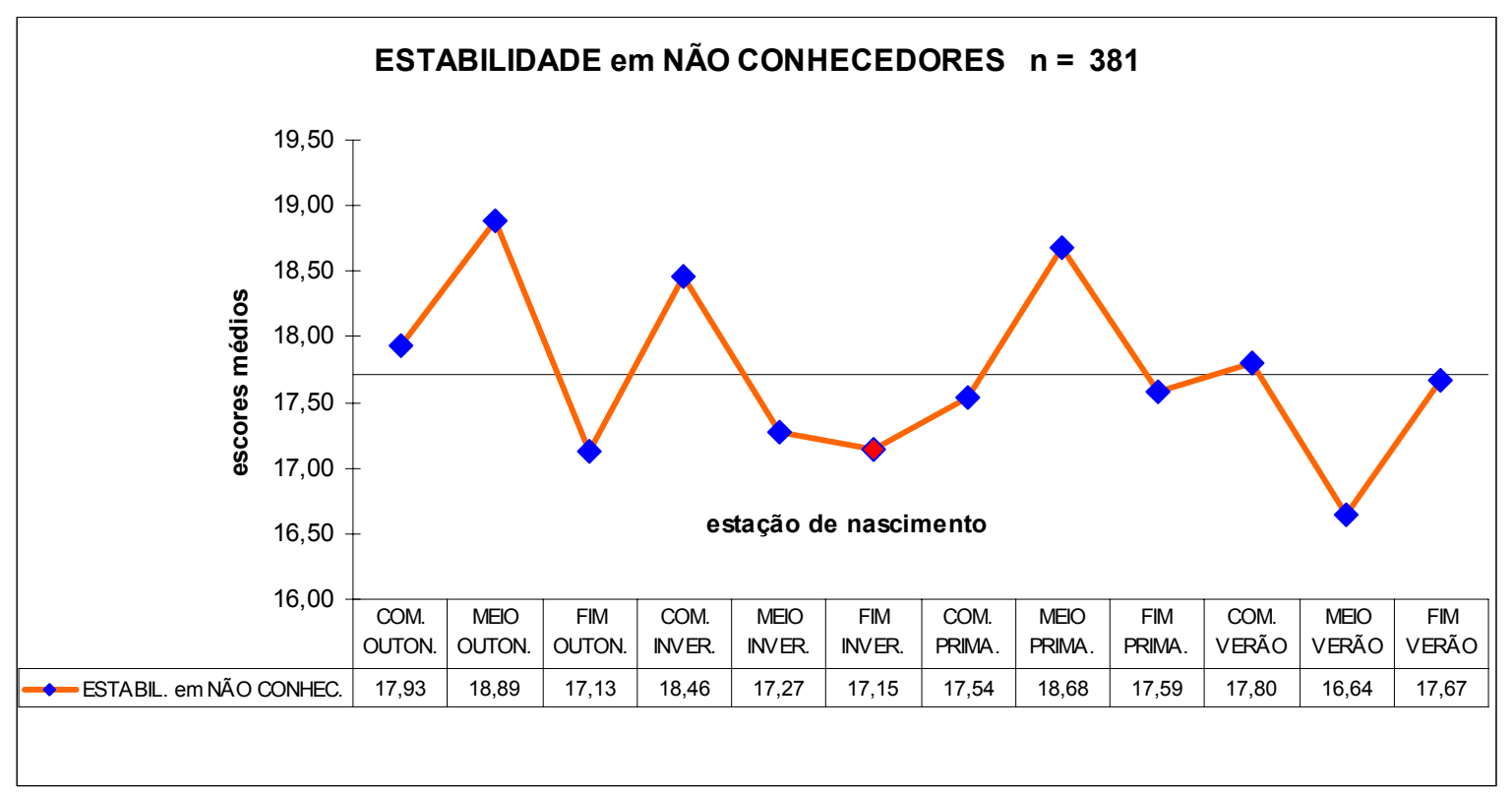

GRÁFICO XIX

Podemos observar no Gráfico XIX que ocorreu uma variação astrológica significativa para o grupo de não conhecedores, os signos da Água e da Terra (Pares) com resultados acima da média, exceto os do Fim do Inverno e do Fim do Verão. A variação também é muito semelhante à da distribuição da Inteligência, conforme o padrão do Gráfico VIII, e de fato há uma correlação Pearson de + 0,58 entre as médias.

Tabela 31: ESTABILIDADE EMOCIONAL no grupo de não conhecedores

\begin{tabular}{|l|r|r|r|r|}
\hline Grupo & \multicolumn{1}{|l|}{ Contagem } & \multicolumn{1}{l|}{ Soma } & \multicolumn{1}{l|}{ Média } & \multicolumn{1}{l|}{ Variância } \\
\hline SIGNOS ímpares & 179 & 3098 & 17,31 & 11,60731 \\
\hline SIGNOS pares & 202 & 3650 & 18,07 & 11,00015 \\
\hline
\end{tabular}

Tabela 32: ANOVA

\begin{tabular}{|l|r|r|r|r|r|r|}
\hline Fonte da variação & \multicolumn{1}{|l|}{$S Q$} & $g l$ & $M Q$ & $F$ & Valor P & F crítico \\
\hline Entre grupos & 55,11121 & 1 & 55,11121 & 4,88345 & 0,02771 & 3,86612 \\
\hline Dentro dos grupos & 4277,13026 & 379 & 11,28530 & & & \\
\hline$\Sigma$ & 4332,2415 & 380 & & & & \\
\hline
\end{tabular}




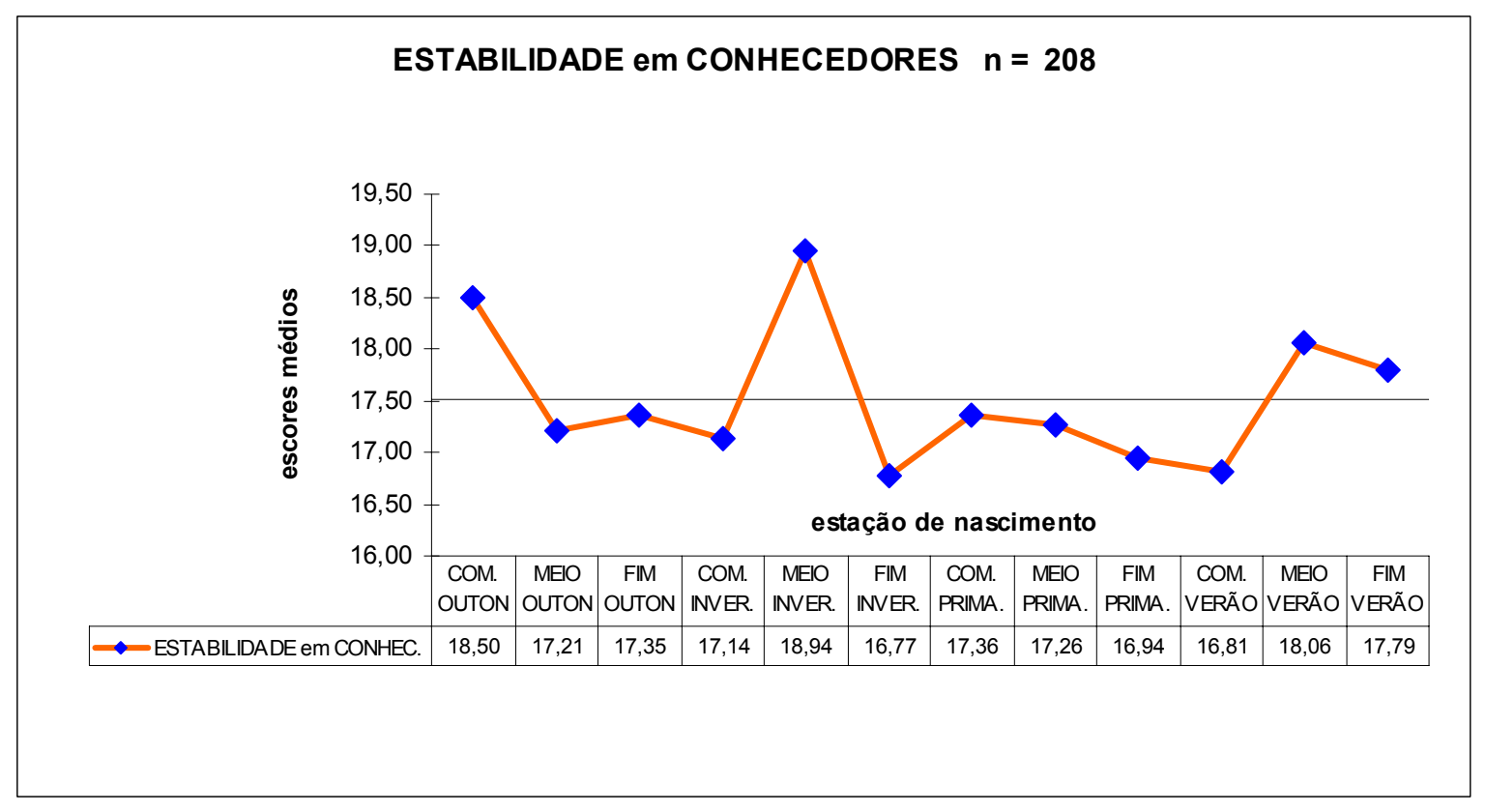

GRÁFICO XX

Percebemos no Gráfico XX que neste grupo de conhecedores não há nenhuma variação identificável por qualquer critério sazonal ou astrológico, como está demonstrado nas Tabelas 33 e 34. Já não se apresenta o padrão obtido entre os não conhecedores, ou seja, parece que há uma variação de base astrológica na Estabilidade Emocional que independe do conhecimento astrológico.

Tabela 33: ESTABILIDADE EMOCIONAL para grupo de conhecedores

\begin{tabular}{|l|r|r|r|r|}
\hline RESUMO & Contagem & \multicolumn{1}{l|}{ Soma } & \multicolumn{1}{l|}{ Média } & Variância \\
\hline Grupo & 96 & 1720 & 17,92 & 10,32982 \\
\hline SIGNOS ímpares & 112 & 1922 & 17,16 & 13,57754 \\
\hline SIGNOS pares &
\end{tabular}

Tabela 34: ANOVA

\begin{tabular}{|l|r|r|r|r|r|r|}
\hline Fonte da variação & \multicolumn{1}{|l|}{$S Q$} & gl & \multicolumn{1}{l|}{ MQ } & F & Valor P & F crítico \\
\hline Entre grupos & 29,54029 & 1 & 29,54029 & 2,44543 & 0,11940 & 3,88700 \\
\hline Dentro dos grupos & 2488,44048 & 206 & 12,07981 & & & \\
\hline Total & 2517,98077 & 207 & & & & \\
\hline
\end{tabular}




\subsubsection{DESCONFIANÇA NO GRUPO DE NÃO CONHECEDORES}

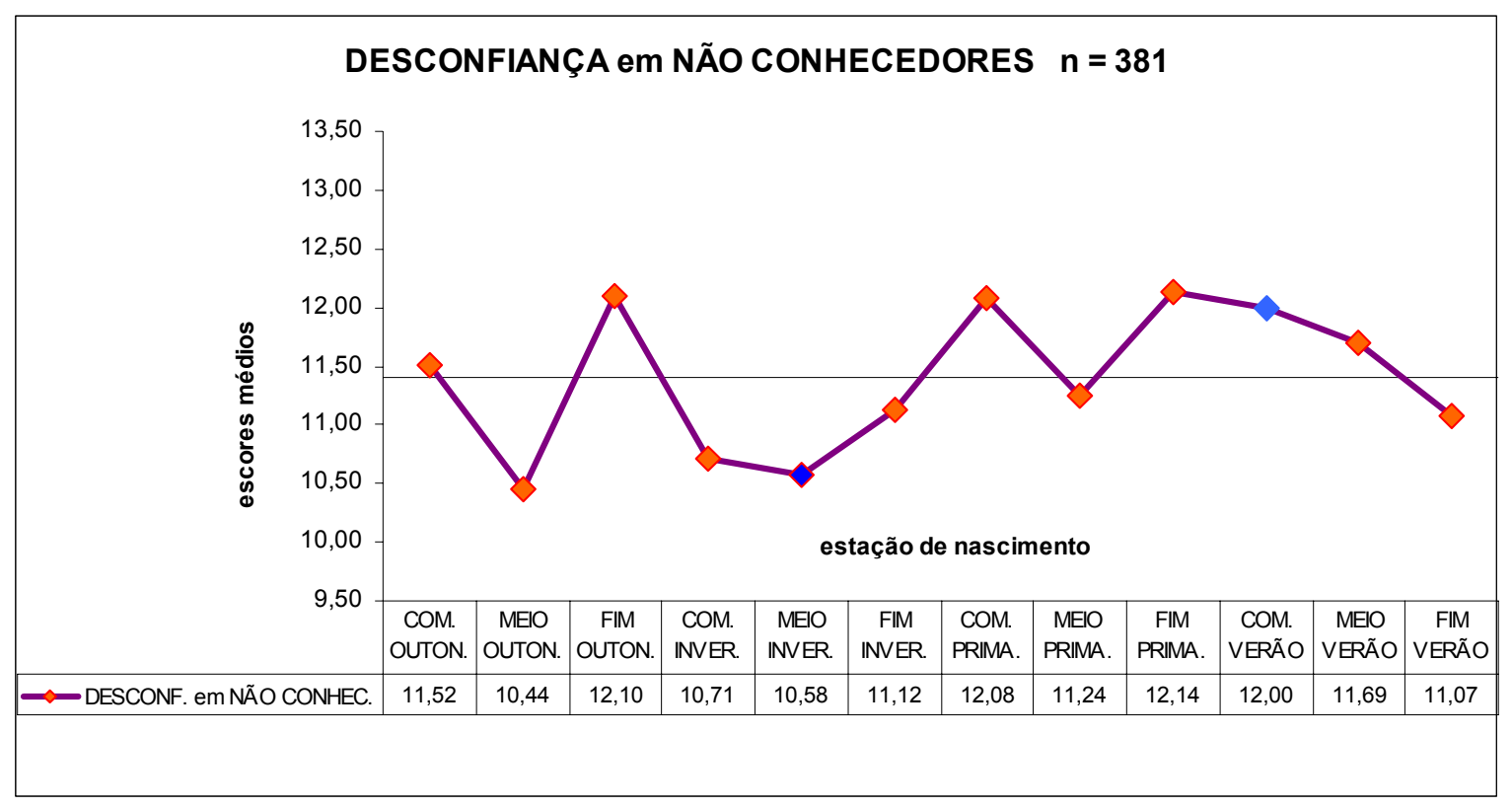

GRÁFICO XXI

Vemos aqui no Gráfico XXI que a variação em dente-de-serra apresenta-se parcialmente entre os não conhecedores, com os grupos dos signos ímpares exceto um (Meio do Inverno) acima da média, e os grupos dos signos pares exceto um (Começo do Verão) abaixo da média. Há uma variação marginalmente significativa que independe do conhecimento, como podemos ler nas Tabelas 35 e 36.

Tabela 35: DESCONFIANÇA para grupo de não conhecedores RESUMO

\begin{tabular}{|l|r|r|r|r|}
\hline \multicolumn{1}{|c|}{ Grupo } & \multicolumn{1}{c|}{ Contagem } & \multicolumn{1}{c|}{ Soma } & \multicolumn{1}{c|}{ Média } & Variância \\
\hline SIGNOS ímpares & 179 & 2094 & 11,70 & 8,08826 \\
\hline SIGNOS pares & 202 & 2248 & 11,13 & 9,72464 \\
\hline
\end{tabular}

Tabela 36: ANOVA

\begin{tabular}{|l|r|r|r|r|r|r|}
\hline \multicolumn{1}{|c|}{ Fonte da variação } & \multicolumn{1}{c|}{$S Q$} & $g l$ & \multicolumn{1}{c|}{$M Q$} & $F$ & Valor P & F crítico \\
\hline Entre grupos & 30,79189 & 1 & 30,79189 & 3,43809 & 0,06449 & 3,86612 \\
\hline Dentro dos grupos & 3394,36296 & 379 & 8,95610 & & & \\
\hline$\Sigma$ & 3425,15486 & 380 & & & & \\
\hline
\end{tabular}




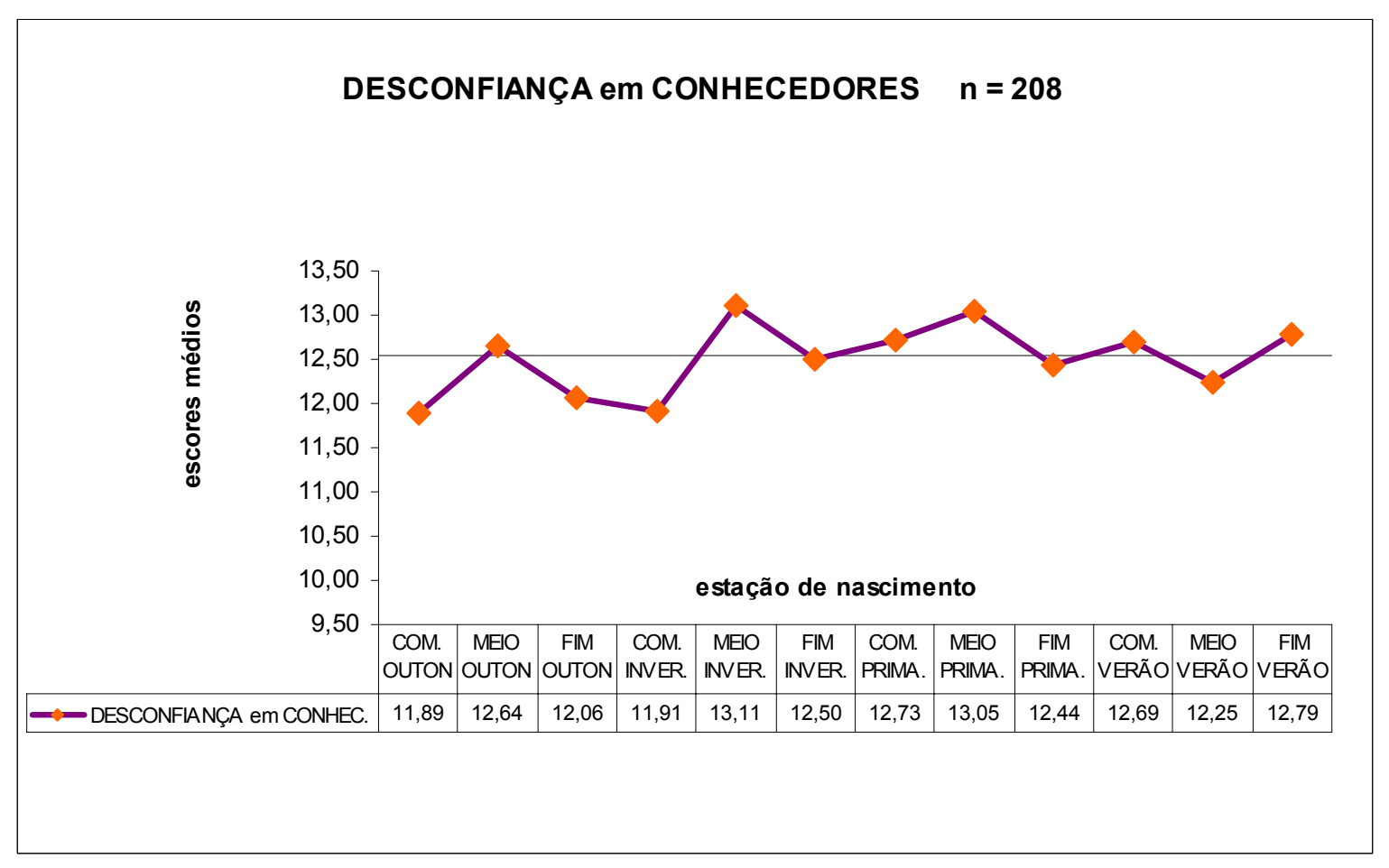

GRÁFICO XXII

Neste grupo percebe-se claramente pelo Gráfico XXII que não há nenhuma variação astrológica nem sazonal significativa no fator Desconfiança para o grupo de conhecedores da astrologia, e as Tabelas 37 e 38 nos confirmam isso. Portanto a variação aproximada do padrão dente-de-serra neste fator só ocorre entre os não conhecedores.

Tabela 37: DESCONFIANÇA no grupo de conhecedores RESUMO

\begin{tabular}{|l|r|r|r|r|}
\hline \multicolumn{1}{|c|}{ Grupo } & Contagem & Soma & Média & Variância \\
\hline SIGNOS ímpares & 96 & 1190 & 12,40 & 7,73640 \\
\hline SIGNOS pares & 112 & 1408 & 12,57 & 7,76062 \\
\hline
\end{tabular}

Tabela 38: ANOVA

\begin{tabular}{|l|r|r|r|r|r|r|}
\hline \multicolumn{1}{|c|}{ Fonte da variação } & \multicolumn{1}{c|}{$S Q$} & \multicolumn{1}{c|}{$g l$} & \multicolumn{1}{c|}{$M Q$} & $F$ & Valor $P$ & F crítico \\
\hline Entre grupos & 1,5938 & 1 & 1,59386 & 0,20567 & 0,65066 & 3,88700 \\
\hline Dentro dos grupos & 1596,3869 & 206 & 7,74945 & & & \\
\hline Total & 1597,9807 & 207 & & & & \\
\hline
\end{tabular}


Ao compararmos os resultados da Desconfiança para os grupos de conhecedores e não conhecedores, apresentados conjuntamente no Gráfico XXIII, vemos que o grupo de conhecedores está unificado, como se vê no Gráfico e se confirma na Tabela 39, todo acima da média geral, levando à conclusão de uma correlação positiva entre altos níveis de desconfiança interpessoal e conhecimento da astrologia. De fato a média geral em Desconfiança da padronização brasileira (em 1962) é igual a 10,90 e desvio padrão igual a 3,3; a média geral da amostra $=11,81$. A média entre os conhecedores é $=12,49$; e entre os não conhecedores é $=11,40$. O teste de comparação das médias dos conhecedores com a média geral da amostra $(t=-3,00407, \mathrm{p}=0,003)$ nos confirma esta diferença, permitindo supor que o grupo de conhecedores se afasta para cima da média dos brasileiros, o que é apoiado pela sua diferenciação altamente significativa do grupo de não conhecedores conforme mostrado na Tabela 40.

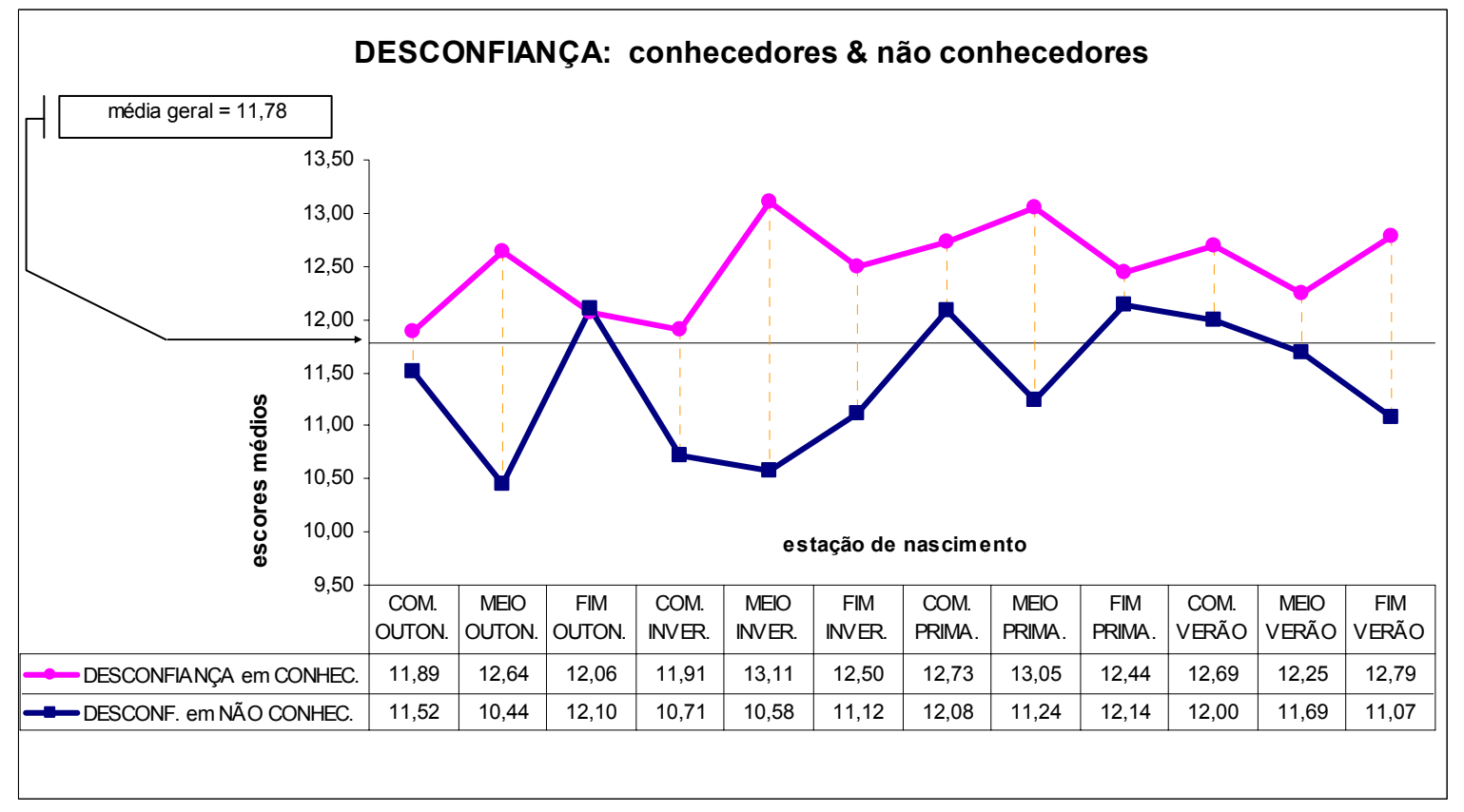


Tabela 39: DESCONFIANÇA \& CONHECIMENTO DE ASTROLOGIA

\begin{tabular}{|l|l|l|r|r|}
\hline RESUMO Grupo & & & & \\
\hline \multicolumn{1}{|c|}{ Contagem } & Soma & \multicolumn{1}{c|}{ Média } & Variância \\
\hline DESCONFIANÇA em conhecedores & 208 & 2598 & 12,49 & 7,71971 \\
\hline DESCONFIANÇA em não conhec. & 381 & 4342 & 11,40 & 9,01357 \\
\hline
\end{tabular}

Tabela 40: ANOVA

\begin{tabular}{|l|c|r|r|r|r|r|}
\hline \multicolumn{1}{|c|}{ Fonte da variação } & \multicolumn{1}{c|}{$S Q$} & \multicolumn{1}{c|}{$g l$} & \multicolumn{1}{c|}{$M Q$} & \multicolumn{1}{c|}{$F$} & Valor $P$ & F crítico \\
\hline Entre grupos & 161,04774 & 1 & 161,04774 & 18,82 & 0,00002 & 3,85735 \\
\hline Dentro dos grupos & 5023,1356 & 587 & 8,55730 & & & \\
\hline Total & 5184,1833 & 588 & & & & \\
\hline
\end{tabular}




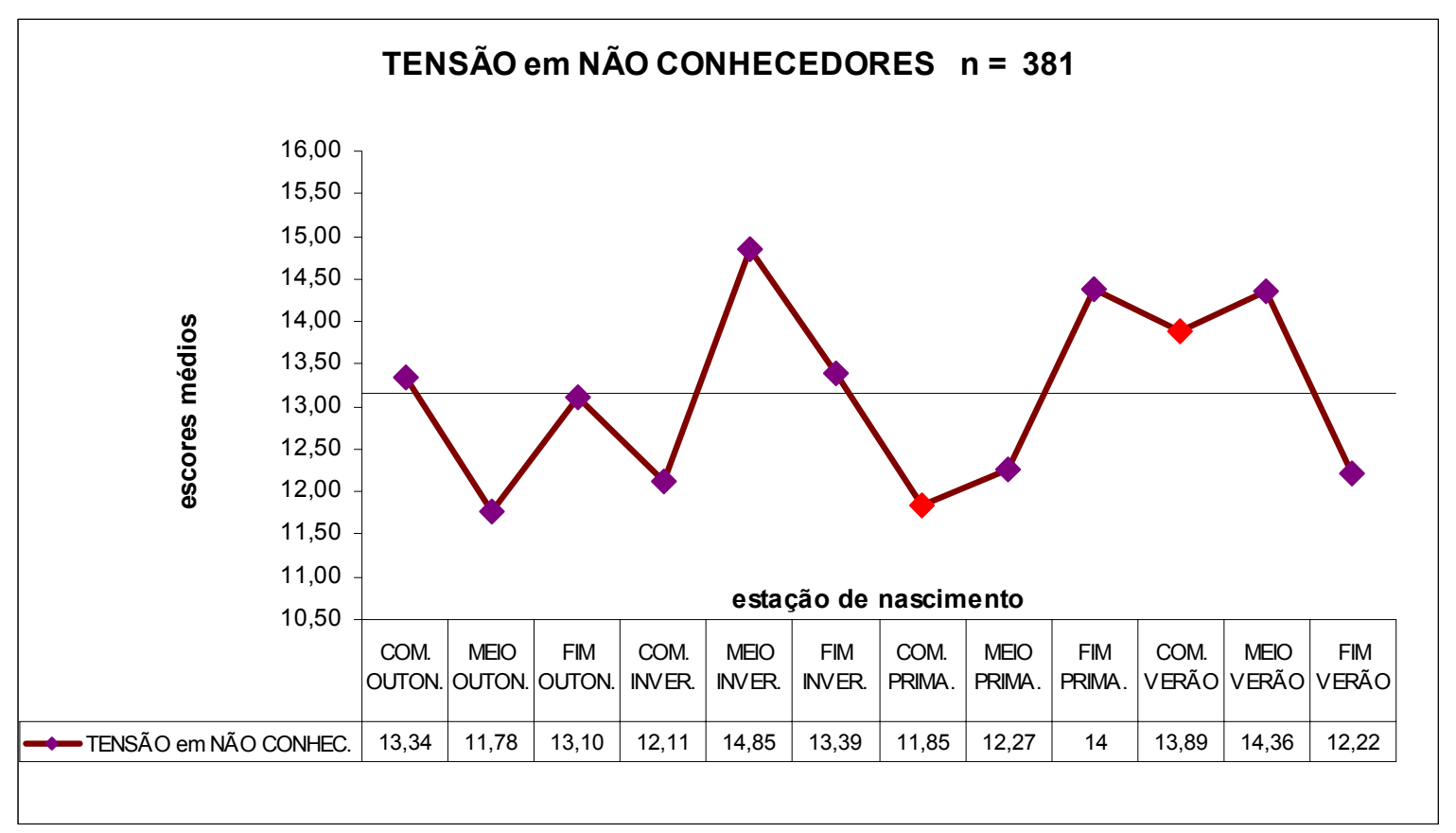

GRÁFICO XXIV

Para a Tensão, que é o fator componente da Ansiedade mais largamente dependente de fatores situacionais (CATTELL, EBER, TATSUOKA, 1970), aparece significativamente o padrão dente-de-serra entre os não conhecedores, com as exceções do Começo da Primavera e Começo do Verão.

Tabela 41: TENSÃO para grupo de não conhecedores RESUMO

\begin{tabular}{|l|r|r|r|r|}
\hline \multicolumn{1}{|c|}{ Grupo } & \multicolumn{1}{c|}{ Contagem } & \multicolumn{1}{c|}{ Soma } & \multicolumn{1}{c|}{ Média } & Variância \\
\hline SIGNOS ímpares & 179 & 2451 & 13,69 & 21,14663 \\
\hline SIGNOS pares & 202 & 2561 & 12,68 & 18,65714 \\
\hline
\end{tabular}

Tabela 42: ANOVA

\begin{tabular}{|l|r|r|r|r|r|r|}
\hline \multicolumn{1}{|c|}{ Fonte da variação } & \multicolumn{1}{c|}{$S Q$} & $g l$ & $M Q$ & $F$ & Valor P & F crítico \\
\hline Entre grupos & 97,67880 & 1 & 97,67880 & 4,92672 & 0,02704 & 3,86612 \\
\hline Dentro dos grupos & 7514,18472 & 379 & 19,82634 & & & \\
\hline$\Sigma$ & 7611,8635 & 380 & & & & \\
\hline
\end{tabular}




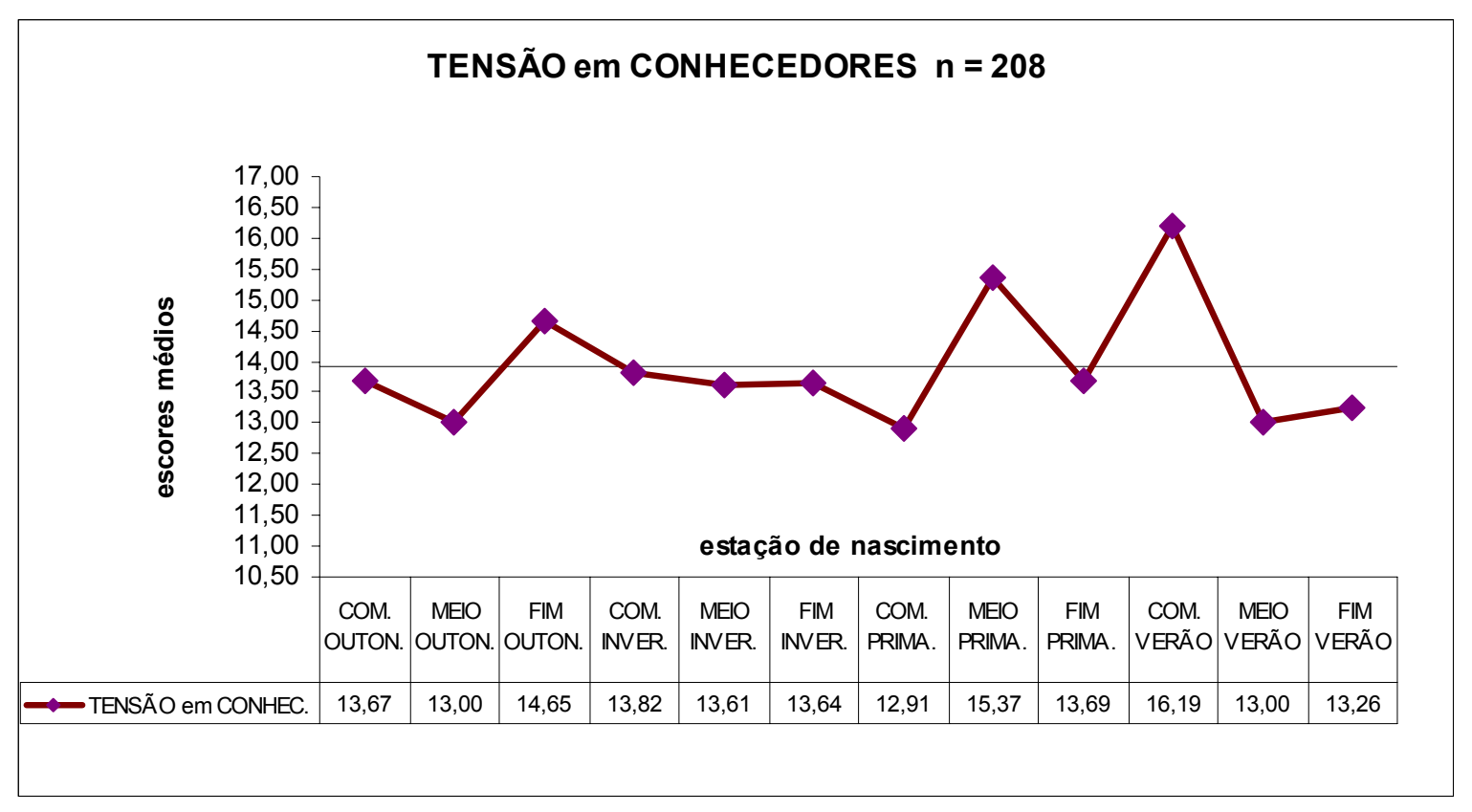

GRÁFICO XXV

Percebemos pelo Gráfico XXV que não há padrão reconhecível, apenas que as médias tendem a aproximarem-se muito mais do que as do grupo dos não conhecedores, sugerindo a existência de uma influência "amortecedora" do conhecimento do signo astrológico para a tensão.

Tabela 43: TENSÃO para grupo de conhecedores

RESUMO

\begin{tabular}{|l|r|r|r|r|}
\hline \multicolumn{1}{|c|}{ Grupo } & \multicolumn{1}{c|}{ Contagem } & \multicolumn{1}{c|}{ Soma } & \multicolumn{1}{c|}{ Média } & Variância \\
\hline SIGNOS ímpares & 96 & 1309 & 13,64 & 18,00252 \\
\hline SIGNOS pares & 112 & 1589 & 14,19 & 18,89245 \\
\hline
\end{tabular}

Tabela 44: ANOVA

\begin{tabular}{|l|r|r|r|r|r|r|}
\hline \multicolumn{1}{|c|}{ Fonte da variação } & \multicolumn{1}{c|}{$S Q$} & $g l$ & $M Q$ & $F$ & Valor P & F crítico \\
\hline Entre grupos & 15,75561 & 1 & 15,75561 & 0,85248 & 0,35693 & 3,88700 \\
\hline Dentro dos grupos & 3807,30208 & 206 & 18,48205 & & & \\
\hline$\Sigma$ & 3823,05769 & 207 & & & & \\
\hline
\end{tabular}


Ao compararmos a Tensão para o grupo dos conhecedores com o grupo dos não conhecedores, conforme apresentado no Gráfico XXVI, ressalta-se uma diferença moderadamente significativa que as Tabelas 45 e 46 confirmam. Aqui novamente apontase para a função do conhecimento astrológico, seria recurso para lidar com tensões relativas a situações sociais, conforme se pode confirmar pela análise também da Desconfiança. Ocorre com a Tensão que a média dos signos impares entre os não conhecedores é significativamente maior que a média dos signos pares, porém a média dos signos ímpares entre os conhecedores é menor que a média dos signos pares. Isto indica que a astrologia pode até mesmo funcionar como redutora de tensão entre os seus conhecedores que sejam de signos ímpares, segundo a hipótese da maior suscetibilidade à informação vinda de fora para estes.

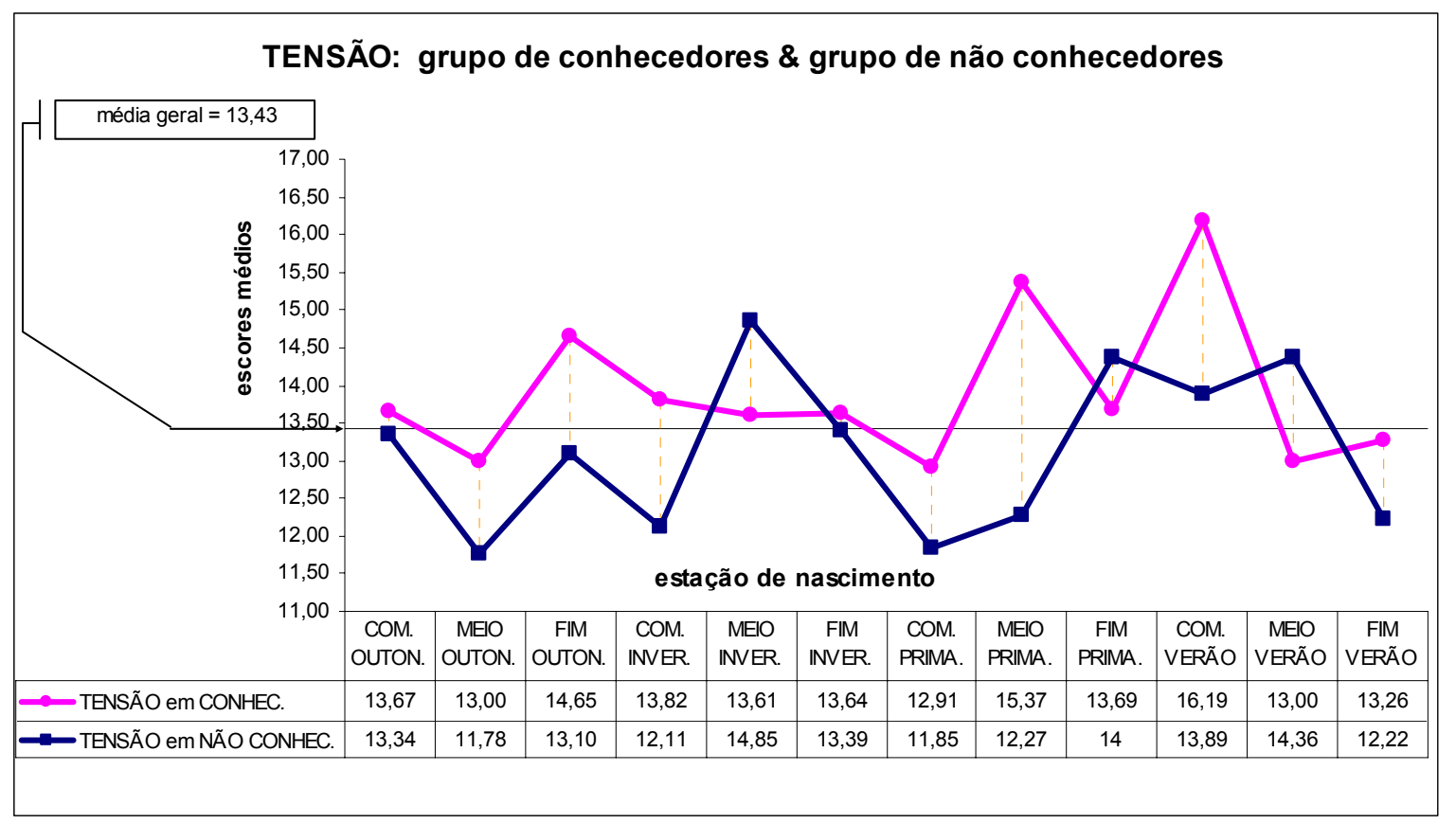

GRÁFICO XXVI 
Tabela 45: TENSÃO \& CONHECIMENTO DE ASTROLOGIA RESUMO

\begin{tabular}{|l|l|l|r|r|}
\hline \multicolumn{1}{|c|}{ Grupo } & Contagem & Soma & \multicolumn{1}{c|}{ Média } & Variância \\
\hline TENSÃO em CONHEC. & 208 & 2898 & 13,93 & 18,46888 \\
\hline TENSÃO em NÃO CONHEC. & 381 & 5012 & 13,15 & 20,03122 \\
\hline
\end{tabular}

Tabela 46: ANOVA

\begin{tabular}{|l|r|r|r|c|r|r|}
\hline \multicolumn{1}{|c|}{ Fonte da variação } & \multicolumn{1}{c|}{$S Q$} & \multicolumn{1}{c|}{$g l$} & \multicolumn{1}{c|}{$M Q$} & $F$ & Valor $P$ & F crítico \\
\hline Entre grupos & 81,40477 & 1 & 81,40477 & 4,17883 & 0,04138 & 3,85735 \\
\hline Dentro dos grupos & 11434,921 & 587 & 19,48027 & & & \\
\hline$\Sigma$ & 11516,326 & 588 & & & & \\
\hline
\end{tabular}


Para a Apreensão, também fator componente da Ansiedade, não apareceram variações significativas como havíamos encontrado da Dissertação (RODRIGUES, 1997), nem entre os não conhecedores $[F=0,00327, p=0,86]$ nem entre os conhecedores $[F=$ $3,07638, p=0,081]$. Isto estabelece que a variação marginalmente significativa em dentede-serra encontrada na Ansiedade para não conhecedores advém de Estabilidade Emocional (-), Desconfiança (+) e Tensão (+), não tendo se apresentado em Desenvoltura (-), Apreensão (+) e Autodisciplina (-).

Aprofundando a análise da Apreensão, vemos que não há diferenças significativas entre as médias dos não conhecedores $(=10,43)$ e conhecedores $(=10,66),[\mathrm{F}=$ 0,51692, $\mathrm{p}=0,47]$. Houve apenas entre os conhecedores uma tendência ao padrão dentede-serra, mas de forma oposta ao que se mediu na nossa Dissertação e ao que vem predominando entre os componentes da Ansiedade entre os não conhecedores. Isto aponta mais uma vez para a função do conhecimento astrológico, neste caso trazendo provavelmente menos apreensão para pessoas mais dependentes de informações externas sobre elas mesmas. Resta avaliar o efeito da sugestão nos grupos, para delimitar melhor a extensão e a duração do efeito da informação do signo astrológico solar entre conhecedores e não conhecedores. 


\subsection{O GRUPO DE CONHECEDORES DA ASTROLOGIA E O EFEITO DA SUGESTÃO}

\subsubsection{INTELIGÊNCIA NO GRUPO COM SUGESTÃO PSICOLOGIA}

Avaliamos aqui o efeito da sugestão, inicialmente no grupo de conhecedores, em busca de verificar se a sugestão Astrologia teve efeito diferenciador para os resultados entre os conhecedores. No caso da Inteligência, qualquer efeito diferenciador seria indicativo da atuação da crença - na própria capacidade de resolver problemas - no desempenho.

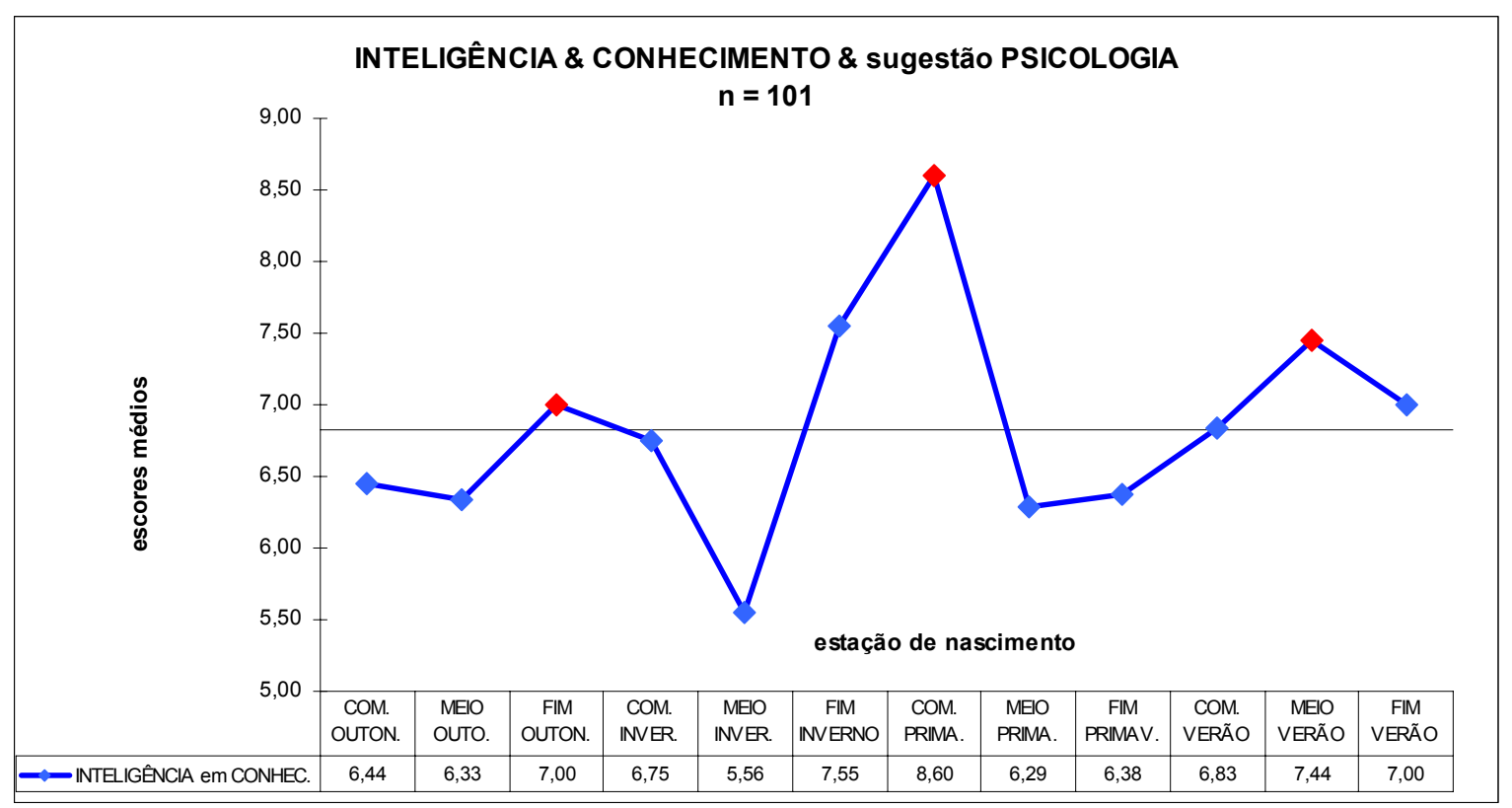

GRÁFICO XXVII

Com a sugestão Psicologia, observamos no Gráfico XXVII que os grupos relativos aos signos do Ar, Gêmeos, Balança (Libra) e Aquário (ali marcados em vermelho), estão entre as quatro médias mais altas. Pode ser expressão da auto-atribuição da “intelectualidade” do Elemento Ar. Mas o grupo é muito pequeno para alguma conclusão. 


\subsubsection{INTELIGÊNCIA NO GRUPO COM SUGESTÃO ASTROLOGIA}

Para verificar o efeito da informação astrológica, fizemos a comparação com o padrão de resultados no grupo que recebeu a sugestão Astrologia, mostrado no Gráfico XXVIII. Contrariando o esperado anteriormente, a sugestão não fez com que os resultados dos signos do Ar, marcados em vermelho, fossem os mais altos, e não há diferença entre os grupos separados por Elementos $[\mathrm{F}(3,101)=0,44930 ; \mathrm{p}=0,72]$. Este resultado também pode ter sido fruto do tamanho deste subgrupo, que teve, por exemplo, apenas seis sujeitos no Começo da Primavera.

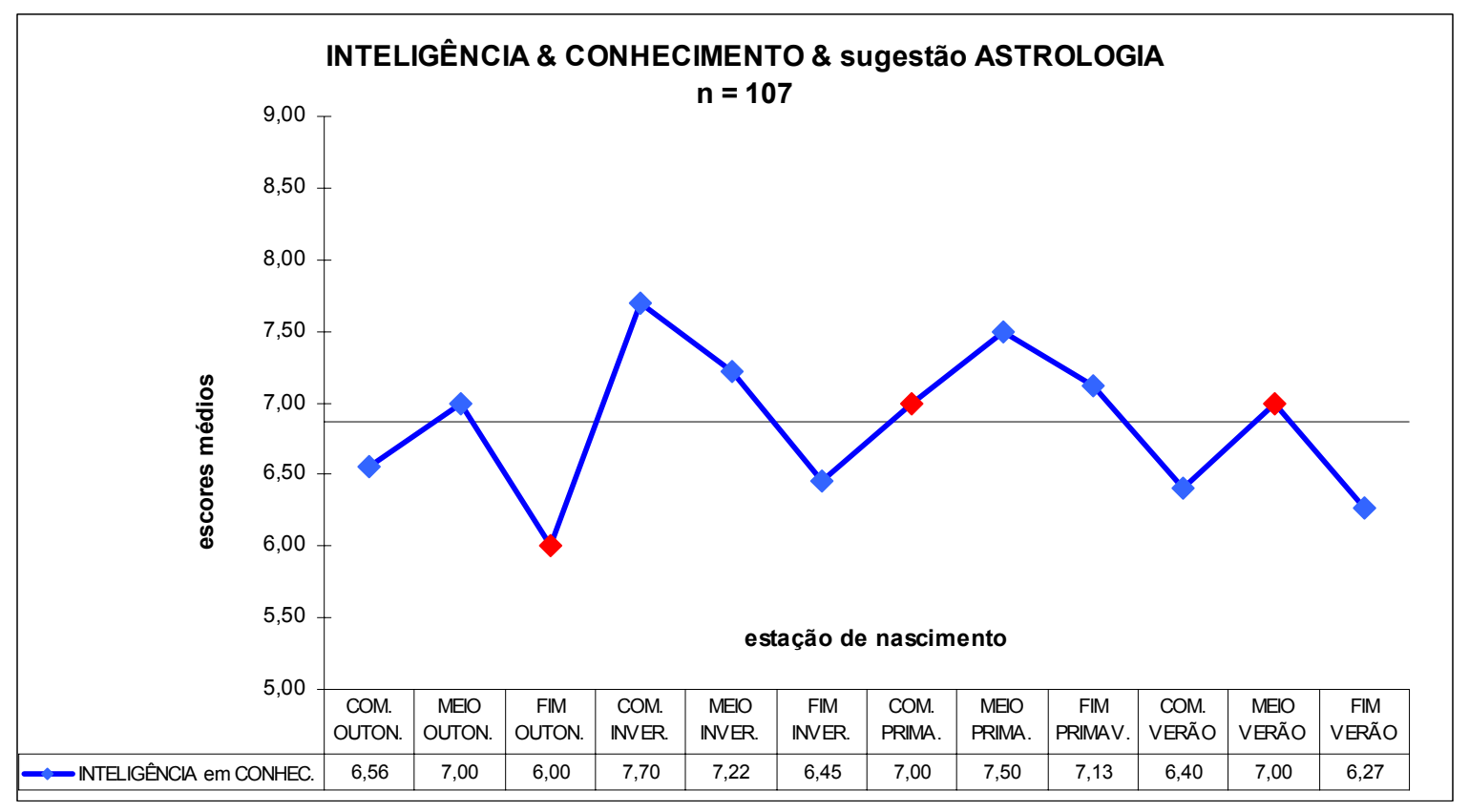

GRÁFICO XXVIII 


\subsubsection{DESPREOCUPAÇÃO NO GRUPO COM SUGESTÃO PSICOLOGIA}

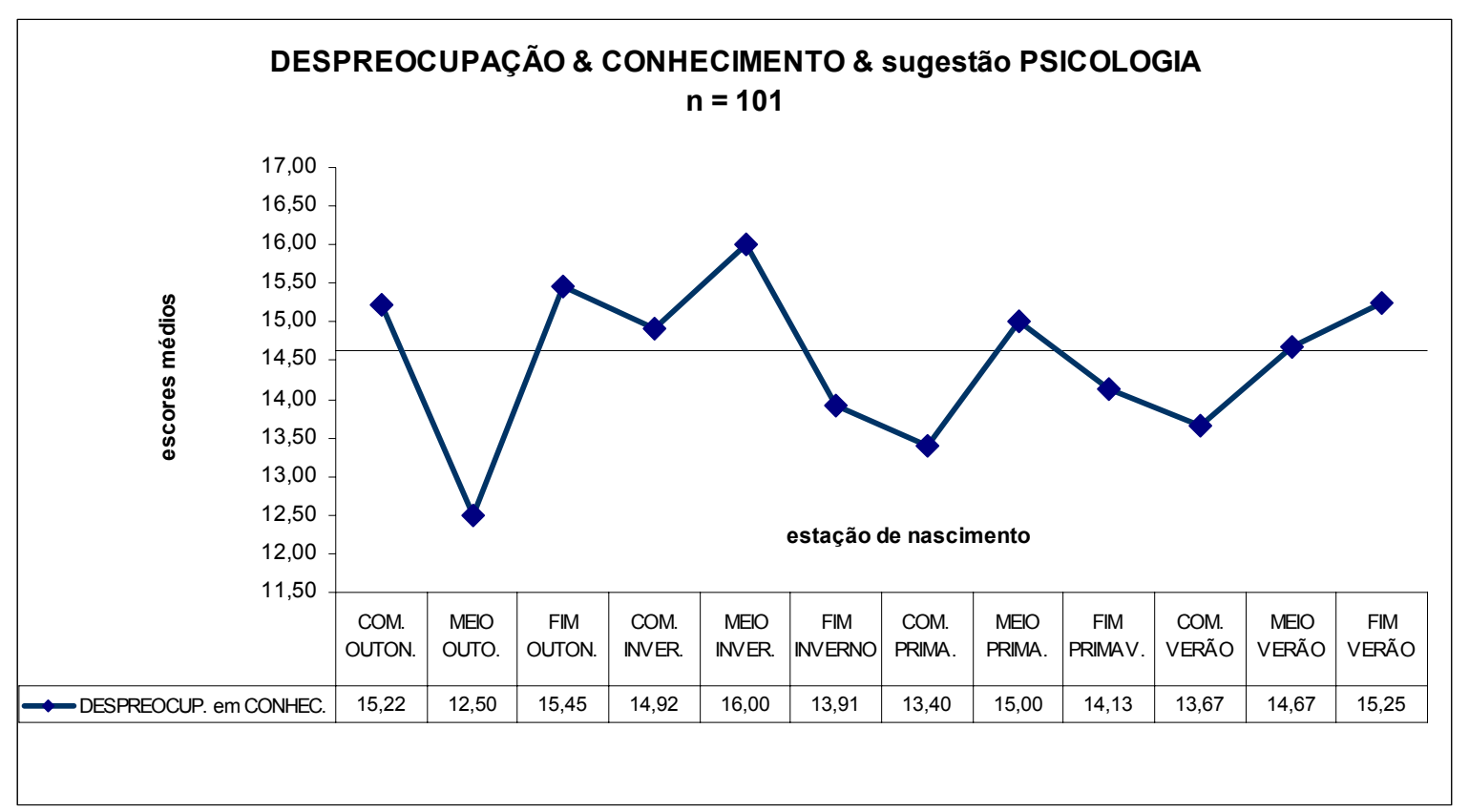

GRÁFICO XXIX

Aqui o padrão dente-de-serra ainda aparece parcialmente, conforme se vê no Gráfico XXIX, até o Fim do Inverno, mas esmaecido pela quebra no Começo do Inverno. Porém a variação não é significativa, como podemos confirmar pelas Tabelas 47 e 48, sugerindo apenas uma leve permanência da influência do conhecimento, independentemente de uma sugestão.

Tabela 47: DESPREOCUPAÇÃO \& Conhecimento \& Sugestão Psicologia

\begin{tabular}{|c|r|r|r|r|}
\hline Grupo & Contagem & Soma & \multicolumn{1}{c|}{ Média } & \multicolumn{1}{c|}{ Variância } \\
\hline DESPREOC. ÍMPAR sugest. PSICO. & 51 & 763 & 14,96 & 7,67843 \\
\hline DESPREOCUP. PAR sugest. PSICO. & 50 & 716 & 14,32 & 10,38531 \\
\hline
\end{tabular}

Tabela 48: ANOVA

\begin{tabular}{|l|r|r|r|r|r|r|}
\hline \multicolumn{1}{|c|}{ Fonte da variação } & \multicolumn{1}{c|}{$S Q$} & \multicolumn{1}{c|}{$g l$} & \multicolumn{1}{c|}{ MQ } & $F$ & Valor P & F crítico \\
\hline Entre grupos & 10,36675 & 1 & 10,36675 & 1,149537 & 0,28625 & 3,93712 \\
\hline Dentro dos grupos & 892,8016 & 99 & 9,018198 & & & \\
\hline Total & 903,1683 & 100 & & & & \\
\hline
\end{tabular}




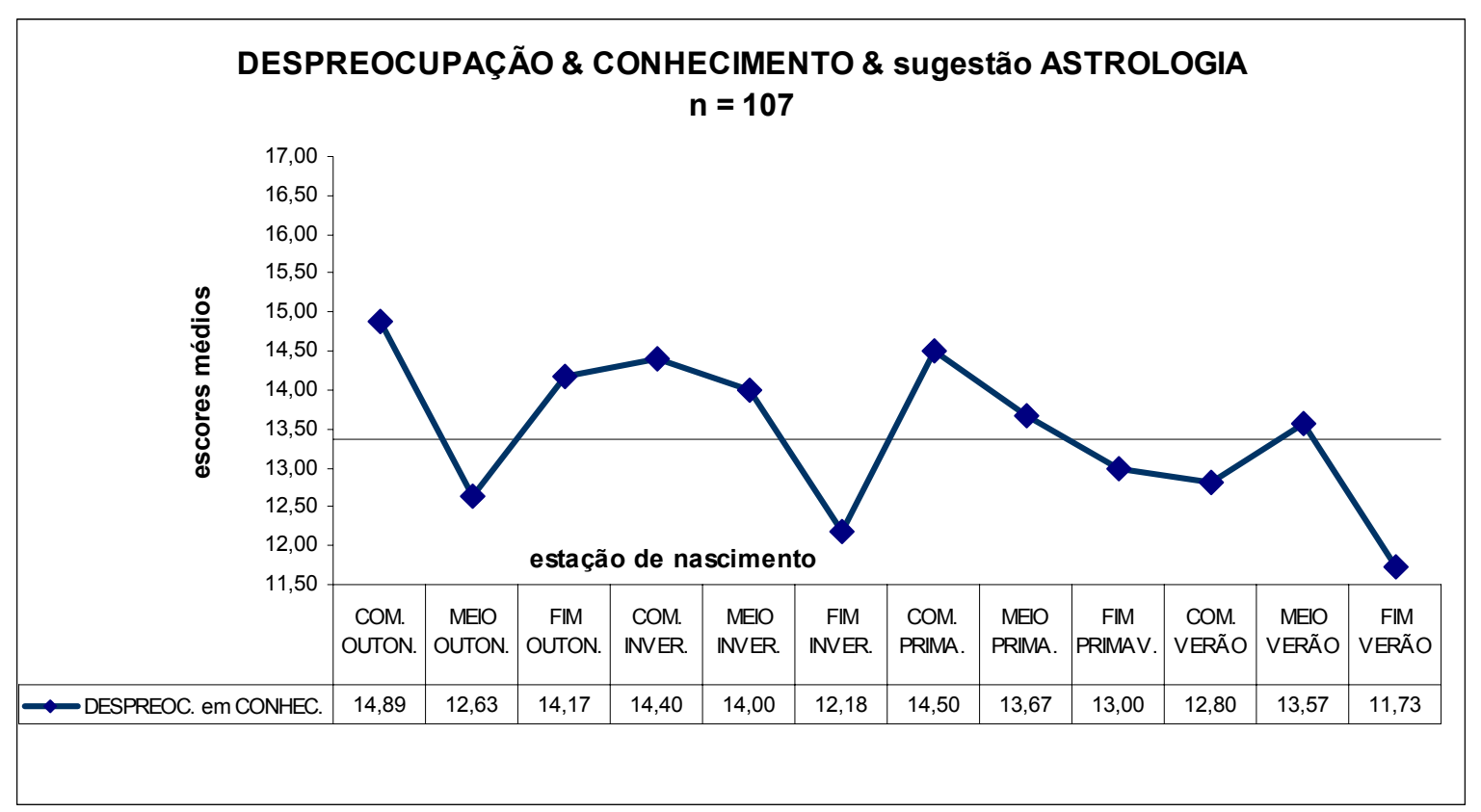

GRÁFICO XXX

Com este subgrupo confirmamos que a influência da sugestão Astrologia não levou a uma maior adequação à predição astrológica, como se vê no Gráfico XXX. Tanto quanto com a Inteligência, pode ser um resultado do pequeno tamanho do grupo.

Tabela 49: DESPREOCUPAÇÃO \& Conhecimento \& Sugestão Astrologia

\begin{tabular}{|c|r|r|r|r|}
\hline Grupo & Contagem & Soma & Média & Variância \\
\hline DESPREOC. ÍMPAR sugest. ASTRO. & 45 & 631 & 14,02 & 15,38586 \\
\hline DESPREOCUP. PAR sugest. ASTRO. & 62 & 800 & 12,90 & 14,51507 \\
\hline
\end{tabular}

Tabela 50: ANOVA

\begin{tabular}{|l|r|r|r|r|r|r|}
\hline \multicolumn{1}{|c|}{ Fonte da variação } & \multicolumn{1}{c|}{$S Q$} & \multicolumn{1}{c|}{$g l$} & \multicolumn{1}{c|}{$M Q$} & \multicolumn{1}{c|}{$F$} & Valor P & F crítico \\
\hline Entre grupos & 32,64960 & 1 & 32,64960 & 2,19420 & 0,14153 & 3,93155 \\
\hline Dentro dos grupos & 1562,3971 & 105 & 14,87997 & & & \\
\hline Total & 1595,0437 & 106 & & & & \\
\hline
\end{tabular}




\section{DISCUSSÃO E CONCLUSÕES}

\subsection{AVALIAÇÃO DA $1^{a}$ DA $2^{a}$ HIPÓTESES}

Não foi confirmada a Hipótese da auto-atribuição = HA-A: Entre os conhecedores, as médias grupais das escalas componentes da Extroversão não foram significativamente mais altas para os signos Quentes do que para os signos Frios $(p=0,098)$, e o mesmo ocorreu entre as médias grupais dos não conhecedores. Houve diferença notável entre os grupos na Despreocupação, conhecedores $(p=0,053)$ e não conhecedores $(p=0,88)$, na direção prevista, mas não foi significativamente diferente a ponto de permitir outra conclusão. Possivelmente este resultado se diferenciou do de Rooij em função de apenas uma minoria da amostra ter recebido a sugestão Astrologia, não permitindo então um efeito da sugestão entre os ímpares \& conhecedores suficiente para diferenciá-los dos pares \& conhecedores.

Foi confirmada pela Extroversão, no entanto, a Hipótese da suscetibilidade à informação diferenciada pela dimensão Frio-Quente = HSFQ: Há nos sujeitos de signos Quentes maior suscetibilidade à informação vinda de fora sobre suas personalidades do que nos de signos Frios, evidenciada na discrepância significativa das médias das escalas componentes da Extroversão nos Quentes \& conhecedores, em relação às médias dos 
Quentes \& não conhecedores $(\mathrm{p}=0,0007)$, e o mesmo não ocorre com as médias dos Frios \& conhecedores em comparação com as médias dos Frios \& não conhecedores $(\mathrm{p}=$ 0,72). A Extroversão variou diferencialmente entre Frios e Quentes.

Também na Despreocupação a hipótese foi apoiada, demonstrada no distanciamento significativo $(\mathrm{p}=0,005)$ para mais da média de Despreocupação para os Quentes \& conhecedores $(=14,48)$, em relação à média dos Quentes \& não conhecedores $(=13,17)$, sendo que a discrepância entre os Frios \& conhecedores $(=13,54)$ e os Frios \& não conhecedores $(=13,23)$ não foi significativa $(\mathrm{p}=0,48)$.

Pode ser que o fato de que - dentre as componentes da Extroversão - a variação diferencial tenha aparecido apenas na Despreocupação se relacione com a natureza da escala, conforme afirmado no Manual (RUSSELL, KAROL, 1999, p. 48): “A exuberância social do fator $\mathrm{F}$ tem um sabor mais impulsivo e vivaz que as outras escalas relacionadas à extraversão (sic)." Poderia ser uma escala mais facilmente relacionável com características conhecidas dos signos do Fogo e do Ar, favorecendo a auto-atribuição. 


\section{2. $3^{a}$ HIPÓTESE: EXTROVERSÃO E CONHECIMENTO ASTROLÓGICO}

Foi confirmada a Hipótese do conhecimento astrológico diferenciado por Extroversão = HCE: Os conhecedores se diferenciam dos não conhecedores significativamente para mais nas médias das escalas componentes da Extroversão. Tivemos que a média em Extroversão entre os conhecedores $(=11,19)$ foi significativamente mais alta $(\mathrm{p}=0,01)$ do que a média em Extroversão $(=10,49)$ entre os não conhecedores. Como o Gráfico VI mostra, muito provavelmente os maiores resultados em Extroversão para os conhecedores não se devem a uma maior concordância com a característica desejável da Extroversão para os de signos ímpares, já que os de signos pares se colocam praticamente na mesma linha, quase igualando a maioria das médias. Podemos dizer que no caso o conhecimento das características do signo se deve à maior Extroversão, e não que haja um autoconceito de extroversão predominantemente derivado da descrição astrológica dos signos. Evidentemente pode haver um efeito de interação para os Quentes por causa da coincidência da extroversão que observam em si mesmos com as descrições astrológicas. 


\section{3. $4^{a}$ HIPÓTESE: ANSIEDADE E CONHECIMENTO ASTROLÓGICO}

Avaliamos todas as diferenças entre os conhecedores e os não conhecedores. $\mathrm{O}$ grupo de conhecedores, conforme a autodescrição, é:

$$
\begin{aligned}
& \text { mais desconfiado }[\mathrm{F}(1,587)=18,81992, \mathrm{p}=0,00002] \\
& \text { mais imaginativo }{ }^{46}[\mathrm{~F}(1,587)=14,80583, \mathrm{p}=0,0001] \\
& \text { mais afirmativo }^{47}[\mathrm{~F}(1,587)=10,62461, \mathrm{p}=0,001] \\
& \text { mais brando }^{48}[\mathrm{~F}(1,587)=8,53478, \mathrm{p}=0,003] \\
& \text { mais radical }{ }^{49}[\mathrm{~F}(1,587)=6,32792, \mathrm{p}=0,012] \\
& \text { mais despreocupado }[\mathrm{F}(1,587)=5,82163, \mathrm{p}=0,016] \\
& \text { mais expansivo }[\mathrm{F}(1,587)=5,19191, \mathrm{p}=0,023], \\
& \text { mais tenso }[\mathrm{F}(1,587)=4,17883, \mathrm{p}=0,041], \\
& \text { e com a soma dos componentes revela-se } \\
& \text { mais extrovertido }[\mathrm{F}(1,587)=6,61119, \mathrm{p}=0,010], \\
& \text { e marginalmente mais ansioso }[\mathrm{F}(1,587)=3,46561, \mathrm{p}=0,063] \\
& \text { que o de não conhecedores. } \\
& \text { O grupo de não conhecedores é: } \\
& \text { mais autodisciplinado }[\mathrm{F}(1,587)=6,87175, \mathrm{p}=0,009]
\end{aligned}
$$

\footnotetext{
${ }^{46}$ Imaginação (M, Imagination / Abastractedness) é a tendência da pessoa a ser “...boêmia, automotivada, de imaginação criadora, subjetiva, interessada em idéias básicas e no 'essencial”".

${ }^{47}$ Afirmação (E, Dominance) é a tendência da pessoa a ser “.... austera, senhora de si, hostil e extrapunitiva, autoritária (para com os outros) mas sem consideração pela autoridade".

${ }^{48}$ Brandura (I, Sensitivity) resulta da "emotividade protegida" em geral dada às mulheres nas famílias, e é a tendência da pessoa a ser "... sensível e delicada, sonhadora, artista, caprichosa e feminina".

${ }^{49}$ Radicalismo ( $\mathbf{Q}_{1}$, Radicalism / Openess to Change) é a tendência da pessoa a ser “...capaz de criticar e levantar dúvidas relativamente a conceitos básicos, ... mais bem informada, menos inclinada a moralizar, mais dada a tentar experiências na vida em geral.”.
} 
Estes resultados quanto à Desconfiança (+), à Autodisciplina (-) e à Tensão (+) vêm apoiar a Hipótese do conhecimento astrológico diferenciado por Ansiedade = HCA: Os conhecedores se diferenciam dos não conhecedores significativamente para mais nas médias das escalas componentes da Ansiedade. O fato de não serem todas as escalas da Ansiedade que se diferenciaram também pode ser interpretado: Esta diferenciação por ansiedade apóia a idéia de que a crença na astrologia, mais do que simplesmente resultar do fato de permitir aumento ou manutenção da auto-estima para aqueles de signos Quentes, e mais do que oferecer significado e previsibilidade para a compreensão do mundo, poderia servir como recurso para lidar com o externo ou subsidia "respostas de combate" (coping) em relação aos fatores ansiogênicos. Permite menos Apreensão e mais Estabilidade Emocional, que são os fatores componentes da Ansiedade que não diferenciaram significativamente conhecedores de não conhecedores. ${ }^{50}$

Em apoio a esta interpretação, temos que a pesquisa sobre correlação entre conhecimento da astrologia e "locus ${ }^{51}$ de controle" percebido demonstrou que os que lidam com esta têm o locus externo (SOSIS, STRICKLAND, HALEY, 1980). A diferença aqui está coerente com esta possibilidade, principalmente devido à Desconfiança, que - por ser medida através de questões que se referem a atribuições de características, disposições e intenções aos outros - pode ser considerada correlacionada ao locus de controle, que poderia ser no caso relacionado a um controle externo em função dos "outros poderosos" (DELA COLETA, 1986).

\footnotetext{
50 Também a Desenvoltura, entre os componentes da Ansiedade (-), não diferenciou conhecedores de não conhecedores, mas é componente $(+)$ também da Extroversão, e, como vimos, os conhecedores são mais extrovertidos. Coerentemente, a média foi ligeiramente, mas não significativamente, mais alta entre os conhecedores.

${ }^{51}$ Locus de controle é um constructo proposto por Julian Rotter (1966), refere-se ao lugar percebido do controle dos acontecimentos, sendo INTERNO ou EXTERNO. É medido por escalas que colocam a pessoa num continuum INTERNO-EXTERNO.
} 
Desde 1959 já se publicaram muitos estudos demonstrando correlações entre locus de controle e variáveis de personalidade, de motivação e de desempenho (DELA COLETA, 1982). Entre as correlações destacamos as seguintes: Sujeitos internos (de locus de controle predominantemente interno) são mais resistentes à(s) influência(s) (sociais) e discriminam que influências aceitarão; apresentam maior força de ego (equivalente à estabilidade emocional); são menos pessimistas, são mais persistentes para solucionar problemas lógicos, são mais persistentes nos esforços para obter maiores resultados (DELA COLETA, 1982, pp. 92-94); outras pesquisas revelaram que tiram maiores notas na escola e maior pontuação em testes de realização acadêmica, e apresentam maior auto-estima (SCHULTZ, SCHULTZ, 2002, p. 225). Já os externos (de locus de controle predominantemente externo, ou "fatalistas") sofreram mais influências afetivas negativas, apresentam mais ansiedade, apresentam mais depressão, sentem mais insatisfação durante interação social, concordam mais com posições maquiavélicas, apresentam visão de futuro negativa, e são mais passíveis de influência de acordo com o status da fonte. (DELA COLETA, 1982, pp. 94-95).

Além dessas correlações com o locus de controle, foram isoladas - numa análise fatorial - quatro crenças que levariam a pessoa na direção da externalidade: crença em um mundo difícil, crença em um mundo injusto, crença de viver em um mundo não previsível, crença de que o mundo é politicamente irresponsável (DELA COLETA, 1982, p. 92). Todas se afinam com tendências a Ansiedade acima da média, com suas componentes Tensão e Desconfiança ${ }^{52}$. E esta desconfiança interpessoal se afina com a busca do conhecimento da astrologia, dado que a astrologia oferece um meio de confirmar uma crença compensatória de previsibilidade dos comportamentos, de si mesmo e dos outros.

\footnotetext{
${ }^{52}$ A pesquisa de Kline e Barrett (1983), que re-fatorou o $16 \mathrm{PF}$ e encontrou apenas sete fatores no lugar de 16, mostrou Desconfiança sendo um deles, isoladamente.
} 
A relação entre Desconfiança e conhecimento aponta para a função da crença na astrologia. Tudo indica que o grupo de conhecedores compartilha de um locus de controle externo. Quando o nível de desconfiança da pessoa é maior do que a média, a astrologia cumpre um papel de fornecer meios para apoiar a crença de que o mundo externo é previsível e então se torna controlável; e também faz previsões que permitem lidar com a ansiedade trazida pela imprevisibilidade das relações sociais (TYSON, 1982). A previsão astrológica informa a pessoa de modo que poderia posicionar-se e preparar-se para esperar algo bom ou ruim, mas previsto, o que diminui a ansiedade, quer seja para o ganho, quer seja para a perda. Então a astrologia serve como instrumento para propiciar a expectativa de controle, permitindo uma "ilusão de controle" sobre o mundo externo, para aqueles que são externos, e especialmente os mais desconfiados (SOSIS, STRICKLAND, HALEY, 1980).

No entanto, também houve diferenças em outros fatores. Qual seria a causa desta diferenciação? Poderíamos encontrar algo em comum entre estes fatores?

De maneira inesperada apareceu que a Afirmação (E, Dominance) foi fortemente diferenciada para mais entre os conhecedores. O fator relaciona-se a ser afirmativo, independente, agressivo, obstinado. A pessoa assim quer "impor sua vontade sobre as dos outros", "subjugar os desejos alheios aos próprios" (RUSSELL, KAROL, 1999, p. 46). A re-fatoração do 16 PF empreendida por Matthews (1989) extraiu da matriz 12 novos fatores, sendo que itens do fator Afirmação (3) juntamente com outros dos fatores Desconfiança (3) e Tensão (2) foram unificados num fator chamado por eles de Agressão (Aggression). Haveria então uma maior hostilidade nas pessoas deste grupo, e talvez um predomínio de ansiedades paranóicas, o que provavelmente também as levou a buscarem o conhecimento da astrologia, para controle e previsão dos comportamentos dos outros. 
A média significativamente mais alta no fator Brandura (I) entre os conhecedores poderia sugerir inicialmente um público predominantemente do sexo feminino, mas a análise da amostra não confirma isto, dado que neste grupo há uma maioria (54\%) de homens, conforme expresso na Tabela 5. Então é provável que a diferença deste grupo em relação aos não conhecedores se dê pelas características de uma certa dependência e uma certa dificuldade em usar o senso prático que tornam atraente o recurso à astrologia, novamente porque esta oferece organização e previsibilidade, propiciando apoio cognitivo para que a pessoa enfrente o mundo concreto e suas exigências.

Os fatores Imaginação $(\mathbf{M})$ e Radicalismo $\left(\mathbf{Q}_{\mathbf{1}}\right)$, de médias mais altas entre os conhecedores, podem também ter contribuído para facilitar a aceitação que têm das proposições astrológicas, tanto porque o pensamento analógico em que a astrologia se baseia exige um trabalho de imaginação, quanto porque o radicalismo pode favorecer a aceitação da idéia da astrologia como conhecimento válido, contrariando hoje de um lado a cosmovisão científica, e, de outro, muitas religiões monoteístas. Também é provável que a maior Imaginação entre os conhecedores se relacione com menor autocontrole para este grupo, dado que esta correlação é uma descoberta das novas pesquisas com o $16 \mathrm{PF}$ com o fator M: "ele se correlaciona com Instabilidade (C-) e Indisciplina $\left(\mathrm{Q}_{3^{-}}\right)$e carrega negativamente no fator global Auto-Controle na Quinta Edição" (RUSSELL, KAROL, 1999, p. 54).

Já para o grupo de não conhecedores indica-se que há o compartilhar da maior internalidade do locus de controle, o que é apoiado por sua maior Autodisciplina. Mas em coerência com a teoria de que o locus de controle tem origem na aprendizagem social da pessoa - como uma internalidade que se mantêm assim enquanto não abalada por fatores ameaçadores ou traumatizantes externos, fazendo com que a crença no controle 
interno se confirme, sem necessidade de recurso a algum meio externo que proponha controle, ainda que ilusório, como a astrologia (TYSON, 1982).

Avaliando as conseqüências desta possível diferenciação pelo locus de controle, podemos perceber que a relação entre Desconfiança e Estabilidade emocional é diferente para os dois grupos, conforme mostrado pelo Gráfico XXXI. Entre os não conhecedores aparece a correlação negativa $(r=-0,46)$, conforme esperada e expressa na equação da Ansiedade $^{53}$. Entre os conhecedores a correlação negativa $(r=-0,06)$ é insignificante, indicando que a astrologia serve para trazer mais Estabilidade Emocional - Força de Ego para os mais desconfiados. Não parece que este resultado corresponda apenas a uma autoimagem idealizada, dado que as médias em Estabilidade Emocional para este grupo não se elevam em relação àquelas do grupo de não conhecedores, nem se acumulam perto do valor mais alto. Parece antes que há algo como uma regressão à média nesse caso, mas induzida pela crença. Sabemos da diferença entre Ansiedade-traço e Ansiedade-estado, e que é a segunda que influencia mais o desempenho (MATTHEWS, DEARY, 1998, p. 72 75). No 16 PF ambas são medidas conjuntamente: “A ansiedade pode advir em resposta a eventos externos ou pode ainda ser gerada internamente" (RUSSELL, KAROL, 1999).

\footnotetext{
${ }^{53}$ equivalente ao Neuroticismo.
} 


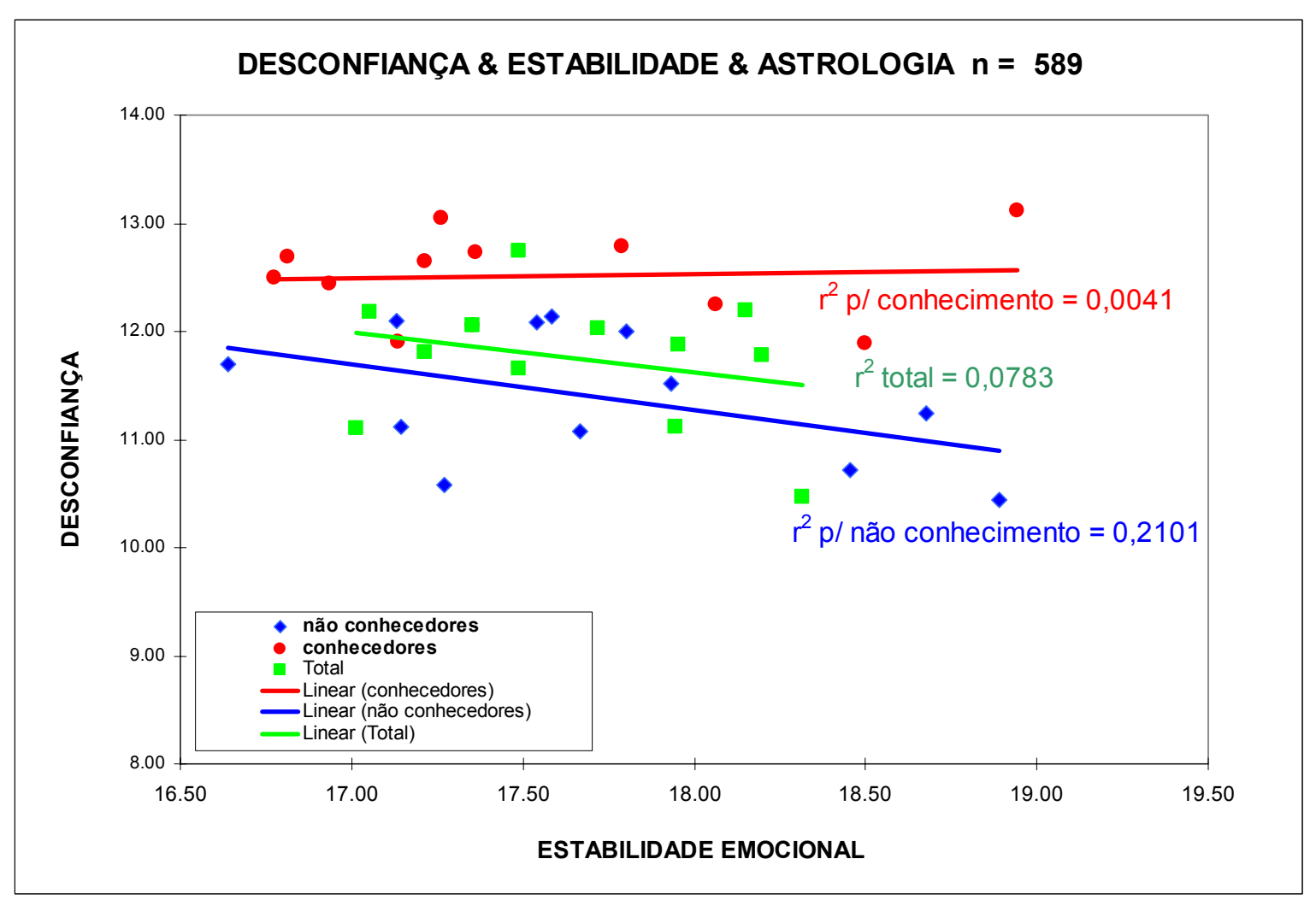

GRÁFICO XXXI

E o fato de que aqueles que conhecem astrologia serem também sistematicamente mais desconfiados que todos os outros do grupo de não conhecedores, mostram que possivelmente experiências de muita ansiedade nas relações humanas os levaram também a buscar a astrologia como meio de lidar (coping) (TYSON, 1982).

Os resultados em Desconfiança sugerem que a maior externalidade faz com que as pessoas procurem a segurança de um sistema de crenças para mecanismo de defesa. "Às vezes, um estado Desconfiado vem em resposta às circunstâncias de vida..." (RUSSELL, KAROL, 1999, p. 52). É compreensível que estes resultados possam ser cotejados com os resultados de Rotter e dos pesquisadores que os seguiram. Fica claro que quem acredita em astrologia tem locus de controle externo. Como se pode ver, a fonte de controle (percebido) tem influência considerável sobre o nosso comportamento, e sobre a maneira como desempenhamos. 
Estes resultados nos levam a questionar a validade de critério das equações de especificação e das interpretações dos perfis de personalidade em busca de previsão de desempenho, se não se levar em conta os estilos de atribuição, o locus de controle e os sistemas de crenças. No caso, a auto-atribuição foi determinante de resultados de autoconceito e de desempenho, então a autodeterminação é tão necessária quanto as determinações sociais e biológicas para o comportamento humano. 


\subsection{A $5^{a}$ HIPÓTESE: INTERAÇÃO ENTRE DIMENSÕES}

Foi moderadamente significativo o resultado em apoio da Hipótese da Ansiedade diferenciada pela dimensão Frio-Quente = HAFQ: Entre os não conhecedores, as médias grupais das escalas componentes da Ansiedade são mais altas para os signos Quentes do que para os signos Frios $(p=0,043)$, mas o mesmo não ocorre entre as médias grupais dos conhecedores.

Entre os componentes da Ansiedade deu-se na Estabilidade Emocional e na Tensão a variação aproximada ao padrão dente-de-serra dentro do grupo de não conhecedores, de forma moderadamente significativa. Isto mostra uma diferenciação de base astrológica que aparentemente não depende apenas do conhecimento em astrologia; e que, muito provavelmente, não foi exclusivamente da Ansiedade. Esta variação fica mais compreensível se relembrarmos a diferença descrita por Rooij, a da "maior suscetibilidade à informação vinda de fora sobre suas personalidades" (1994) para os grupos dos signos ímpares. Apóia-se aqui aquela hipótese apenas como uma parte, relativa apenas a maior suscetibilidade à informação; e ampliando-a para uma suscetibilidade a qualquer influência externa. Haveria então um predomínio da externalidade e da instabilidade emocional. Proponho entendê-los, inicialmente, como “externalizantes”.

Ao contrário, os grupos dos signos pares seriam naturalmente mais “internalizantes", daí serem menos desconfiados, por serem menos dependentes de fatores e influências externas, e por isso passarem a entender a vida mais sob controle interno. A analogia com o que se diferencia astrologicamente os grupos é cabível, os “externalizantes” são Quentes, os “internalizantes” são Frios. 
Quando comparamos os resultados da Extroversão e da Ansiedade entre conhecedores e não conhecedores, vimos que os primeiros, se considerados como um grupo único, têm as médias significativamente mais altas nos dois casos. E o que aparece agora é que, ao separarmos os Quentes de cada grupo e os compararmos, assim como aos Frios de cada grupo, percebemos que têm tendências opostas quanto aos dois Fatores: os Quentes têm média significativamente mais alta $(p=0,0007)$ em Extroversão entre os conhecedores em comparação aos não conhecedores, como já vimos. Já os Frios é que têm média significativamente mais alta $(p=0,002)$ em Ansiedade entre os conhecedores, em comparação aos não conhecedores. O Gráfico XXXII demonstra isto.

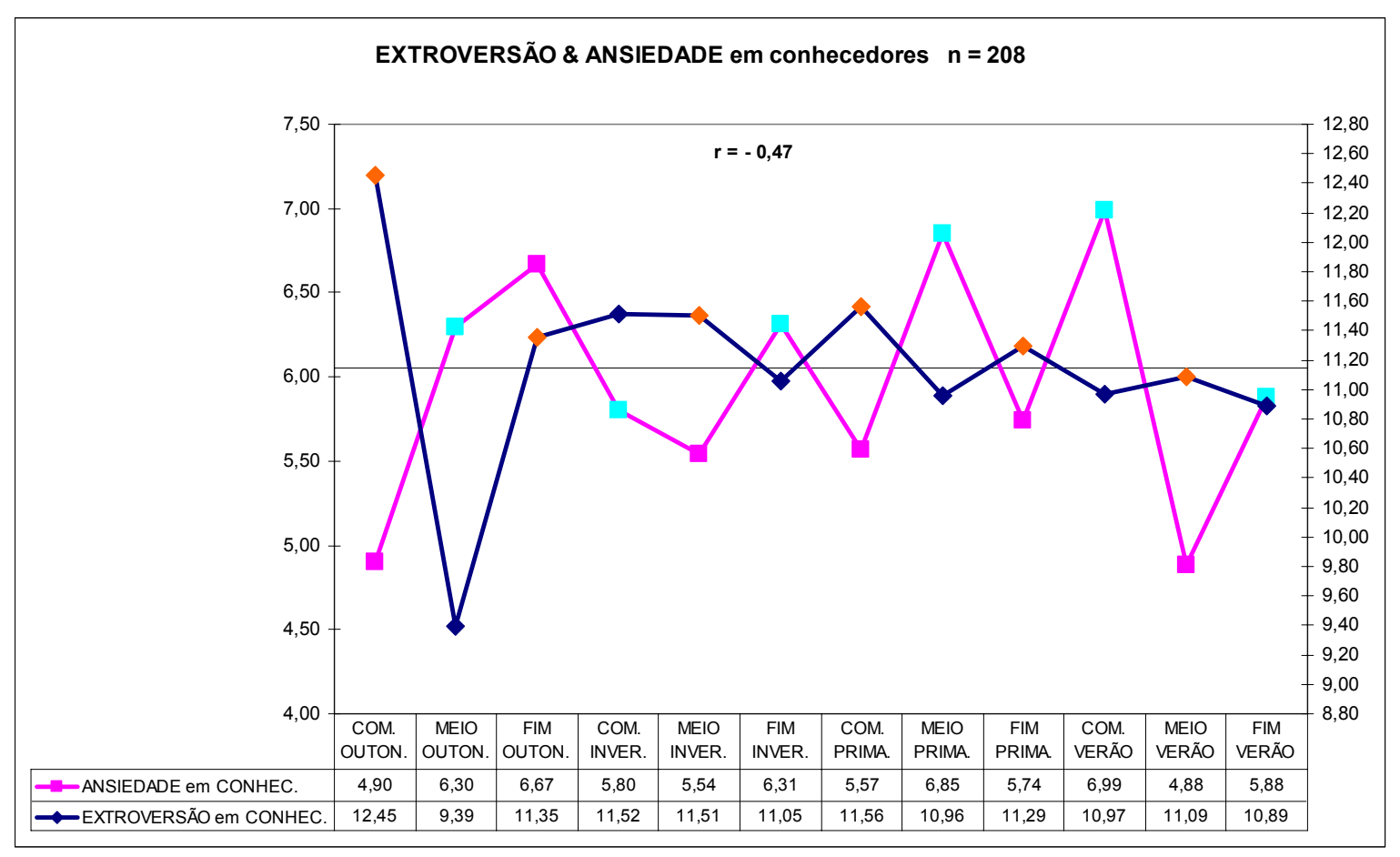

GRÁFICO XXXII

Há uma correlação $r=-0,47$ entre as duas distribuições, e, dado que as duas dimensões são muito independentes por terem uma correlação esperada $r=-$ 0,27 (KRUG, JOHNS, 1986), parece que temos algo relacionado ao conhecimento da astrologia que funcionou como variável interveniente para esta correlação. 
Podemos apoiar esta afirmação, principalmente, se também compararmos os não conhecedores, separados entre Frios e Quentes. Coerentemente, há uma relação inversa entre Extroversão e Ansiedade, com esta sendo significativamente mais baixa devido aos Frios. O Gráfico XXXIII mostra isto.

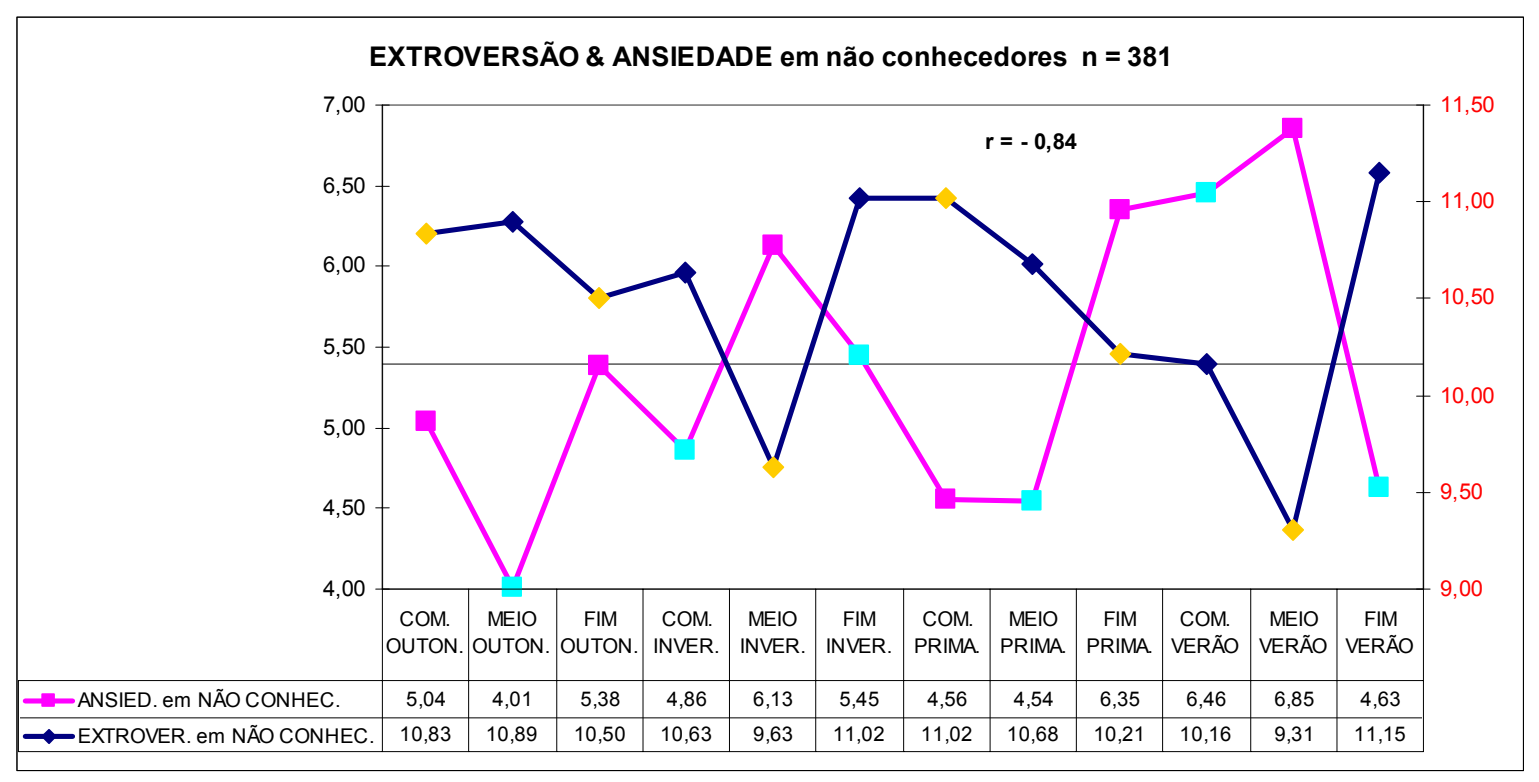

GRÁFICO XXXIII

Há uma correlação $r=-0,84$ entre as distribuições, bem maior ainda $(p=0,0007)$ do que entre os conhecedores. Aqui se demonstra a existência de um fator interveniente, que pode ter se revelado inicialmente na suscetibilidade à informação sobre si mesmo vinda de fora. Esta suscetibilidade está muito provavelmente relacionada a uma predisposição para vivência predominantemente sob causalidade externa, maior entre os Quentes do que entre os Frios. 
Resumindo: Os conhecedores da astrologia são mais extrovertidos e mais ansiosos do que os não conhecedores, mais extrovertidos devido ao subgrupo dos signos Quentes, e mais ansiosos devido ao subgrupo dos signos Frios.

Se compararmos as médias dos quatro grupos gerados pela divisão de Quentes e Frios entre os conhecedores e os não conhecedores, em função da Extroversão e da Ansiedade, podemos perceber claramente sua diferenciação, como demonstrado no Gráfico XXXIV. Avaliando o efeito do conhecimento, expresso pelas setas no gráfico: Há uma separação nítida entre Quentes \& conhecedores e Quentes \& não conhecedores em termos de Extroversão, mas não em termos de Ansiedade, o que apóia a idéia do conhecimento ser usado como fator redutor da Ansiedade. Outra separação nítida dá-se entre os Frios \& conhecedores e os Frios \& não conhecedores, em termos de Ansiedade, mas não de Extroversão, apoiando a idéia de que estes só procuram o conhecimento astrológico por causa da Ansiedade e quando estão acima da média geral da Extroversão. 


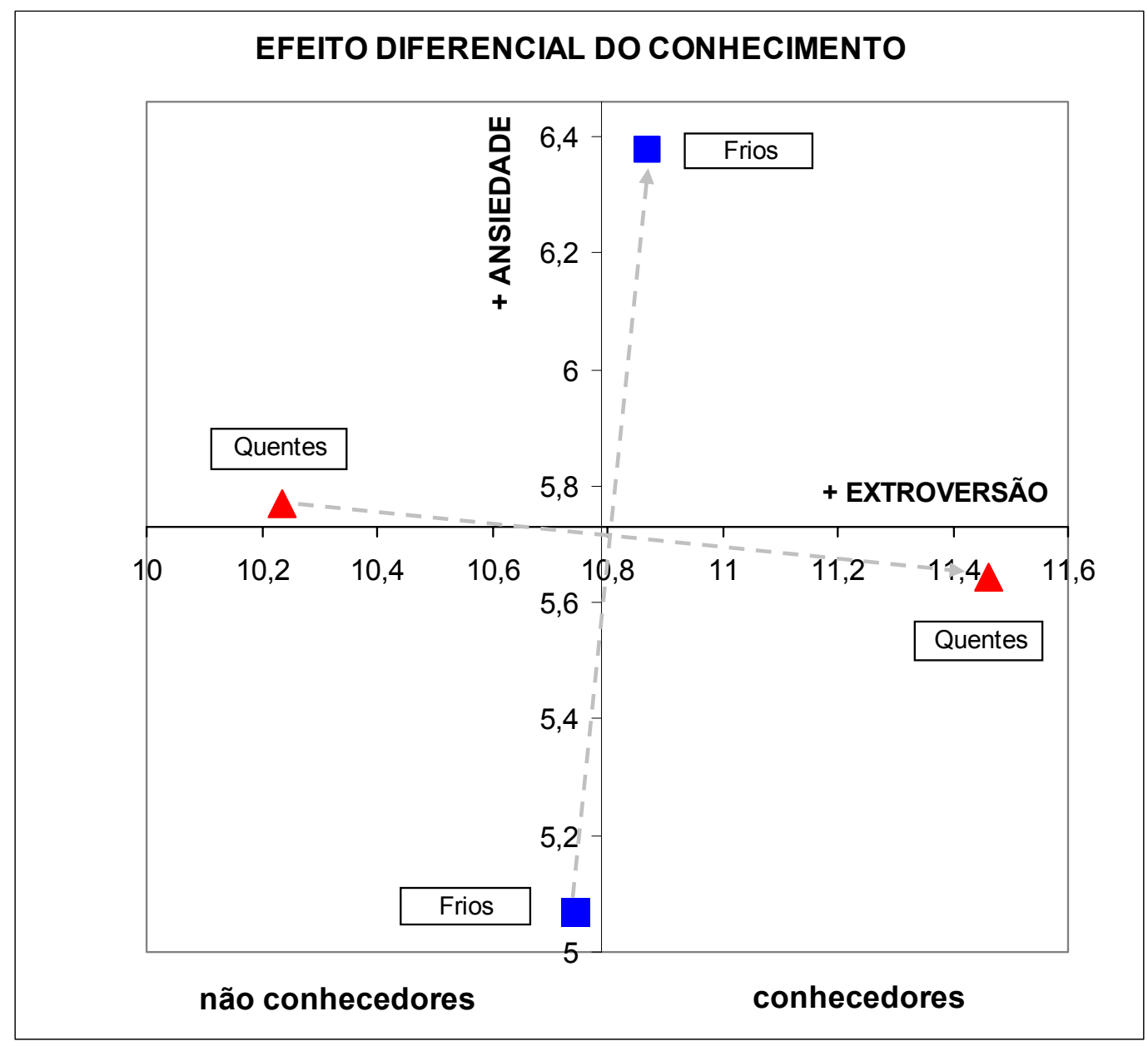

GRÁFICO XXXIV

As quatro médias comparadas em conjunto se diferenciam significativamente, tanto na Extroversão $[\mathrm{F}(3,585)=3,92197, \mathrm{p}=0,009]$, quanto na a Ansiedade $[\mathrm{F}(3,585)=$ $3,41736, \mathrm{p}=0,017] .^{54}$

Não será que a "suscetibilidade à informação vinda de fora sobre a personalidade" apontada por Rooij e repetida aqui seja apenas um efeito combinado da Extroversão e da Ansiedade? Ou seja, a busca do conhecimento em astrologia se daria quando houvesse maior Extroversão e maior Ansiedade? Estas seriam, inclusive, condições para o

\footnotetext{
${ }^{54} \mathrm{O}$ teste de Bonferroni confirma todas as diferenças descritas anteriormente, tanto entre Frios e Quentes quanto entre conhecedores e não conhecedores, na Extroversão e na Ansiedade.
} 
estabelecimento de um locus externo de controle. Dado que a Ansiedade se divide em Ansiedade-traço e Ansiedade-estado, pode ser que a segunda seja diminuída com o conhecimento da astrologia.

Podemos supor o seguinte processo: Quando os sujeitos de signos Quentes são mais extrovertidos e são ou estão mais ansiosos, têm mais contato com e mais busca da informação astrológica sobre suas personalidades, e a coincidência da descrição astrológica com o que podem observar em si mesmos faz com que aceitem mais facilmente as descrições de seus signos. Esta suscetibilidade inicial favorece tanto a criação deste autoconceito de base astrológica quanto os tornam menos ansiosos, como vimos, atuando sobre a Ansiedade-estado. Já os sujeitos de signos Frios, quando são mais extrovertidos e mais ansiosos, tenderiam a tornarem-se também conhecedores da astrologia, como meio de combate (coping), mas mudariam menos no sentido da introversão prevista por seus signos astrológicos devido à incoerência entre o previsto astrologicamente e o observado, e este menor impacto do conhecimento astrológico para eles pode também fazer com que não funcione como redutor de Ansiedade, seja traço ou estado.

Coerentemente com o processo descrito acima, sujeitos de signos Quentes que sejam introvertidos encontrariam pouco sentido na descrição astrológica de seus signos, o que os tornaria não conhecedores, afinal. Isto explicaria a diferença significativa entre os Quentes conhecedores e os não conhecedores. Do mesmo modo, sujeitos de signos Frios que sejam introvertidos e menos ansiosos teriam menor suscetibilidade ao conhecimento em astrologia, mesmo que este fizesse muito sentido devido às descrições de seus signos coincidirem com o que podem observar em si mesmos. Isto explicaria a diferença significativa entre os Frios conhecedores e os não conhecedores. 
No entanto, persiste entre os não conhecedores uma diferença em Ansiedade entre Quentes e Frios - com as médias significativamente mais altas entre os Quentes do que entre os Frios - que não poderia então ser atribuída ao efeito do conhecimento em astrologia. A não ser que haja um efeito diferenciado da informação astrológica sobre as tendências em Extroversão de seus signos, fazendo sentido para os Frios, mas não para os Quentes, que pudesse funcionar de uma maneira inconsciente, de um modo que as pessoas “não soubessem que sabem”. Mas aqui já entramos num espaço especulativo. De início, parece plausível que haja uma diferença entre Quentes e Frios independente de um conhecimento mais aprofundado sobre as características do próprio signo. Isto é apoiado pela análise dos resultados das escalas componentes da Ansiedade entre os 222 não conhecedores que receberam exclusivamente a sugestão Psicologia: A Tensão mantêm a diferença significativa $[\mathrm{F}(1,220)=5,04582, \mathrm{p}=0,026]$ entre Quentes (média $=13,85) \mathrm{e}$ Frios $($ média $=12,51)$, sugerindo que há mesmo alguma diferença que torna os Quentes mais tensos, talvez devido a uma maior suscetibilidade natural a influências externas.

Há então uma diferença de base astrológica entre as pessoas de signos Quentes e Frios, que torna as primeiras mais suscetíveis ao externo. Esta diferenciação poderia advir de um certo nível de influência também das imagens astrológicas, exclusivamente, o que poderia se passar de uma maneira um tanto inconsciente.

Também é possível que haja de fato uma diferença "cosmobiológica” (DEAN, MATTER, 1977, p. 125), ou seja, um ritmo com um ciclo de dois meses, que desse a base cronobiológica para o efeito dessas imagens astrológicas, de onde, afinal, foram originadas. Neste caso não haveria um padrão dente-de-serra, mas um padrão senoidal que acabou por se expressar com dente-de-serra dado que comparamos as médias de cada signo; e o efeito da auto-atribuição entre os conhecedores levaria a uma aproximação deste padrão senoidal inicial para um padrão próximo da onda quadrada. Só com amostras 
muito maiores, comparando novamente conhecedores e não conhecedores, isto poderia ser verificado.

$\mathrm{Na}$ esfera estrita da personalidade poderíamos isolar um fator correlato com uma variação de origem astrológica, em dente-de-serra. Este apareceu entre os não conhecedores nos traços Tensão (+), Estabilidade Emocional (-) e marginalmente na Desconfiança $(+)$ enquanto componentes da Ansiedade, significativamente mais altos para os de Fogo e Ar. Corresponde a um estado real, dado sua influência na Inteligência: a correlação entre as médias de Inteligência com as médias de Ansiedade neste grupo é r = 0,30. Conforme o manual do $16 \mathrm{PF}$ : "Muito embora o raciocínio seja visto como um domínio separado da personalidade, o fator B ainda apresenta algumas pequenas correlações com a Estabilidade Emocional (C+), Confiança (L-) e Experimentação (Q1+).” (RUSSELL, KAROL, 1999, p. 44). Isto - é importante lembrar - na população geral, incluindo conhecedores e não conhecedores da astrologia, daí as correlações serem pequenas. Em nosso caso, em comparação com o grupo dos não conhecedores, a correlação entre as médias de Inteligência com as médias de Ansiedade no grupo dos conhecedores praticamente não existe, é $r=-0,16$.

Houve correlação da Inteligência, para o grupo de não conhecedores, mais significativamente com Estabilidade Emocional, entre os componentes da Ansiedade. A correlação positiva entre a Estabilidade Emocional e Inteligência já é bem conhecida, dado que a variável de personalidade compõe (em sentido oposto) o traço mais amplo Ansiedade (Neuroticismo), que por sua vez interfere no desempenho de uma pessoa, ou por induzi-la a menos autoconfiança, ou por afetar sua concentração. Então é um fator "não intelectivo" da inteligência, moderador entre a aptidão e o desempenho. Podemos ver isto claramente no Gráfico XXXV, que mostra a influência da Estabilidade na Inteligência entre os não 
conhecedores, com $r=0,58$ entre as escalas. Sabemos que a pessoa que tem mais senso de capacidades pessoais se sente mais confiante para a realização de tarefas, e tende a persistir mais. Os que são assim conseguem ter melhores resultados do que têm aqueles que não se acreditam capazes de resolver problemas em geral. Têm mais auto-eficácia: crença de poder dominar, ou de ter dominado, alguma tarefa específica ${ }^{55}$ (BANDURA, 1982).

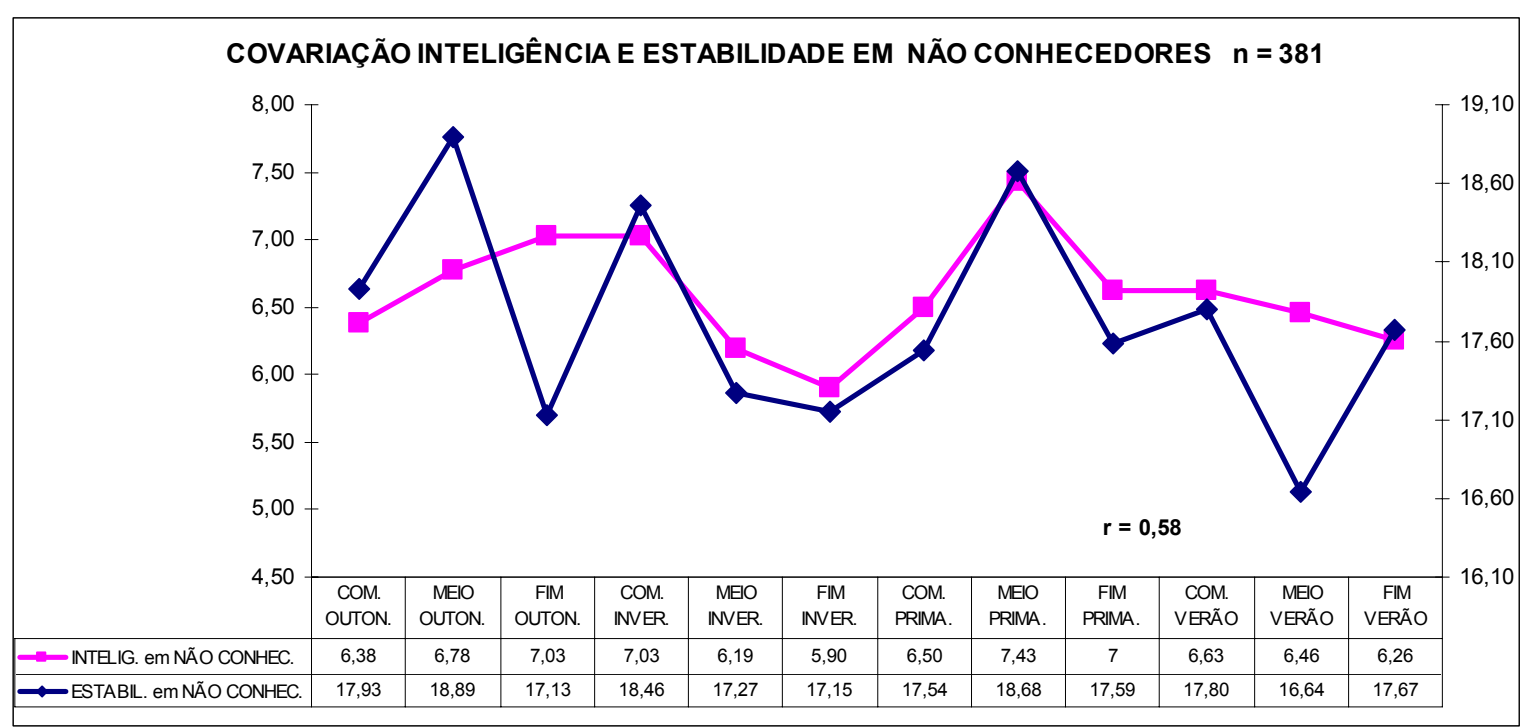

GRÁFICO XXXV

Pode-se observar que os únicos grupos entre os não conhecedores que divergem significativamente em Inteligência do padrão da Estabilidade Emocional são aqueles do Fim do Outono e Meio do Verão, que são signos do Ar. Podemos pensar que estas pessoas, ainda que não possam ser tidas como conhecedoras de astrologia, de algum modo conhecem algo sobre seus signos, e a "intelectualidade" desejável advinda do Elemento Ar as levassem a fazer uma auto-atribuição de capacidade intelectual, mas apenas isso. E que isso acabasse melhorando a média geral desses grupos nos testes de raciocínio.

\footnotetext{
55 “...peoples's judgements of their capabilities to organize and execute courses of action required to attain designated types of performances. It is concerned not with te skills one has but with judgements of what one can do with whatever skills one possesses.” (Bandura, 1986, p.391)
} 
Então, se for confirmada uma diferenciação de origem astrológica em termos de suscetibilidade ao externo, para aqueles de Fogo e Ar o fator decisivo do desempenho estaria na auto-atribuição de capacidade. Neste caso a auto-eficácia seria construída predominantemente por informações externas sobre as próprias capacidades. Podemos supor neste caso que a pessoa "se constrói" predominantemente com interesse consciente no que vem de fora para dentro.

Para aqueles de Terra e Água, o fator decisivo de seu desempenho estaria na autoeficácia construída pela auto-observação e pela observação das próprias realizações. Podemos supor que para estes casos a pessoa se constrói predominantemente com interesse consciente no que vem de dentro para fora.

Para os grupos relativos aos signos do Fogo e do Ar, os resultados em Inteligência indicaram uma dependência da crença na afirmação externa sobre a própria inteligência do tipo que pode ser trazida pela informação astrológica - conforme demonstrado pelo Gráfico XII onde aqueles dos signos do Ar do grupo de conhecedores da astrologia obtiveram melhores resultados relativos em Inteligência, de uma maneira totalmente discrepante dos resultados em Inteligência para aqueles dos signos do Ar do grupo de não conhecedores, que podem ser revistos no Gráfico XI. 
De fato podemos perceber no Gráfico XXXVI que para o grupo de não conhecedores há uma covariação $[F(1,10)=4,94480 ; p=0,050]$ entre Inteligência e Estabilidade Emocional, sendo que esta tem carga fatorial de 0,33 naquela.

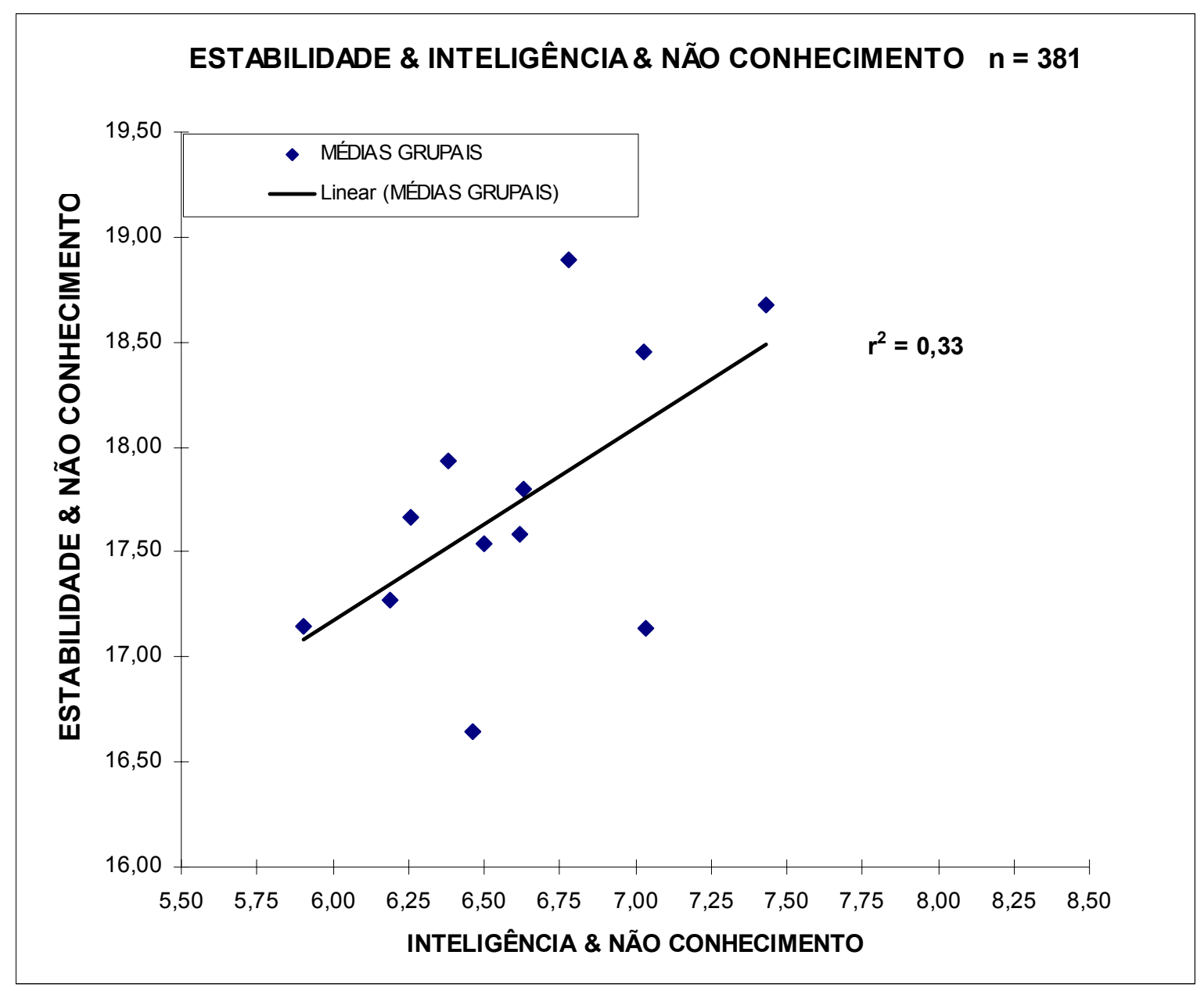

GRÁFICO XXXVI 
Já para o grupo de conhecedores esta covariação $[\mathrm{F}(1,10)=1,09412 ; \mathrm{p}=0,32]$ praticamente não existe dada a carga fatorial de apenas 0,10 , o que é visível no Gráfico XXXVII; então podemos entender que para este grupo os resultados de Inteligência dependem mais da auto-atribuição advinda de um autoconceito de base astrológica do que da Estabilidade Emocional.

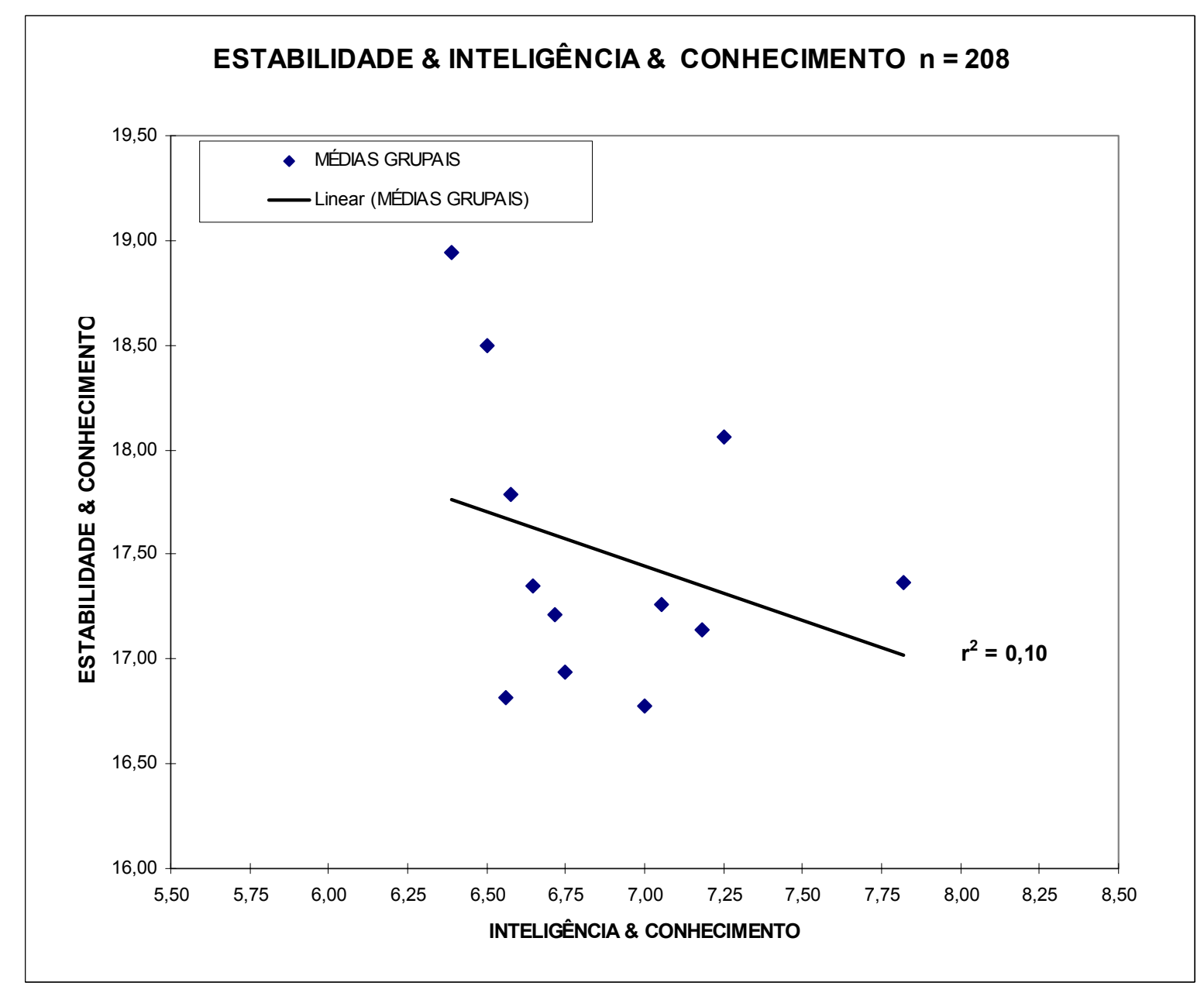

GRÁFICO XXXVII

A hipótese pode não ter sido apoiada através da variação isolada da Inteligência porque surgiu uma variação sazonal somando-se à astrológica: Podemos entender que se o frio ambiental ao nascer pode ser fator levemente prejudicial ao desenvolvimento do 
potencial da Inteligência, parece que também o seria o calor excessivo do verão brasileiro, como se percebe no Gráfico XI.

Mas o mais marcante é que esta variação da Inteligência - especialmente da maneira como é medida pelo $16 \mathrm{PF}$ - foi muito provavelmente decorrência da variação significativa da Ansiedade.

Então como se pode compreender que tenha havido naquela amostra da Dissertação uma variação em dente-de-serra na Inteligência, e nesta amostra não? Pode-se especular que seja devido exatamente ao fato de que o que varia em conformidade com a dimensão Frio-Quente seja algo que combine Extroversão e Ansiedade, e não a Inteligência, a qual só acompanhou isto $^{56}$. De fato, por uma re-análise nos dados da Dissertação (RODRIGUES, 1997) temos que há uma inesperada correlação de $r=-0,39$ entre as médias da Inteligência e as da Extroversão naquela amostra, principalmente devido à Despreocupação (Impulsividade), com $r=-0,62$; e há uma correlação $r=-0,41$ com a Ansiedade, principalmente devido à Tensão, com $r=-0,46$. A combinação destes fatores, que se aproximaram da variação em dente-de-serra (lembremos que ali não separamos os sujeitos pelo conhecimento da astrologia), induziu a variação em dente-de-serra para a Inteligência.

Mais ainda, uma variável como o locus de controle, advinda da aprendizagem social das pessoas, pode ter interagido diferencialmente com as componentes da Ansiedade. Naquela amostra - em que não se separou "conhecedores" de "não conhecedores" e nem se deu a pista "astrologia" a uma parte do grupo - as componentes que variaram perto do padrão dente-de-serra foram a Autodisciplina e a Apreensão; nesta,

\footnotetext{
${ }^{56}$ Pode ser que aquele grupo fosse composto predominantemente de não conhecedores da astrologia, o que é apoiado pelo fato de que era um grupo de cientistas e pesquisadores, talvez por isso se assemelharem mais aos do grupo de não conhecedores desta amostra.
} 
entre os não conhecedores, foram a Tensão, a Estabilidade Emocional e a Desconfiança, e nada disso entre os conhecedores.

Entendemos então que o fator definido pela dimensão Frio-Quente é um fator de suscetibilidade ao mundo externo, talvez relacionado ao locus de controle, por aparecer na auto-atribuição diferenciada entre Quentes e Frios nos resultados da Extroversão ( $\mathrm{p}=$ 0,018 ) entre os conhecedores comparados com o total da amostra (demonstrando a suscetibilidade à informação astrológica como uma conseqüência da suscetibilidade maior ao mundo externo), e aparecer claramente distinguindo Frios de Quentes na Ansiedade (p $=0,043)$, entre os não conhecedores, e seus componentes: Na Tensão $(p=0,027)$, somada com a Instabilidade Emocional $(p=0,028)$ e acompanhada pela Desconfiança $(p=0,064)$.

Nossa amostra é de brasileiros predominantemente jovens, sendo que a média bruta da população brasileira em Desconfiança é atualmente no 16 PF Quinta Edição = 13,50 em comparação com a média bruta norte-americana $=11,11$. O fator ter aparecido através Ansiedade pode ser uma decorrência das condições sociais de violência, crescentemente presentes no Brasil. Torna-se compreensível que para os "externalizantes" o grau de Ansiedade seja maior, devido à sua necessidade maior de relacionamento e sua maior dependência de condições externas, com o que se expõem mais a situações ameaçadoras.

Foi necessário propor esta variável em função da observação de uma variação coerente e conjunta dessas dimensões em conformidade com a predição trazida pela distribuição dos signos divididos pela escala Frio-Quente no zodíaco matemático. 
Qual seria a origem desta variável de personalidade coerente com a escala FrioQuente?

Uma base teórica poderia vir do fato de que existem na cultura de massa a preservação e a divulgação daquelas representações sobre temperamentos baseadas nos Elementos (BACHELARD (1938), 1990), e que se organizam dentro de um esquema prévio, abstraído, como vimos no exemplo teórico do Circumplexo Interpessoal. Estes "esquemas cognitivos" são determinadores de crenças sobre diferenças pessoais (MARTINDALE, MARTINDALE, 1988) e podem acabar por determinar de forma duradoura o autoconceito, em decorrência da história das relações sociais da pessoa, em que ela pratique o que acredita que é. Haveria então a tendência da pessoa a entender-se, pela auto-atribuição, como Quente ou Fria, e também como Dominante ou Humilde.

Assim há uma coincidência entre uma “dimensão básica” (MARTINDALE, MARTINDALE, 1988) de atribuição, uma cognição sobre si mesmo e uma informação cultural. No caso da Afirmação, isto parece que se repetiu: Pelo esquema do Circumplexo Interpessoal relacionado aos Elementos, temos que pessoas Dominantes foram entendidas como relacionadas ao Fogo, em primeiro lugar, e em seguida ao Ar. Enquanto as pessoas Humildes foram associadas em primeiro lugar à Água e em segundo lugar à Terra. Se compararmos Fogo e Ar em nossa amostra, temos que a média deles no grupo dos conhecedores $(=15,79)$ se distancia significativamente para mais em Afirmação $(\mathrm{p}=$ 0,005), em comparação com a média $(=14,41)$ deles no grupo dos não conhecedores. Comparando agora entre Terra e Água, ainda que tenham as médias no grupo dos conhecedores $(=15,47)$ maiores dos que no grupo de não conhecedores $(=14,71)$, esta distância é bem menor e menos significativa $(\mathrm{p}=0,079)$. Aparentemente, na nossa amostra, as pessoas conhecedoras das características dos seus signos solares do Ar e do 
Fogo fizeram mais para si mesmas a auto-atribuição de uma característica de Afirmação ou Dominância com a imaginação dos Elementos Ar e Fogo.

Seria possível medir o efeito do Circumplexo Interpessoal funcionando como esquema cognitivo na auto-atribuição mesmo entre os não conhecedores, através de alguma escala? Sabemos que apenas a Estabilidade Emocional e a Tensão, componentes da Ansiedade, variaram significativamente pela comparação entre Frios e Quentes. Estes fatores não são previstos no circumplexo usado aqui. Além disso, a Extroversão dentre os não conhecedores tem média maior para os Frios do que para os Quentes. Parece então que o Circumplexo de Wiggins associado aos Elementos não é usado para auto-atribuição entre os não conhecedores. Assim sendo, reforça-se o apoio à hipótese de uma diferença na personalidade entre pessoas de signos Quentes comparadas às de signos Frios que não depende do conhecimento de (pelo menos) três características de seu signo solar. A menor Estabilidade Emocional e a maior Tensão para os de signos Quentes pode indicar uma diferente predisposição em relação ao mundo, de base biológica. Reforçam-se assim as hipóteses cosmobiológicas (EYSENCK, NIAS, 1982, p. 218) de ciclos, que não seriam incoerentes com as hipóteses da cronobiologia (WENDT, 1978). Haveria então algo próprio dos Temperamentos do Fogo e do Ar, respectivamente Colérico e Sanguíneo? Haveria uma instabilidade geral, associável às imagens exemplares da chama e do vento? Talvez esta predisposição entre os Quentes levasse a uma maior suscetibilidade, e a uma conseqüente maior vulnerabilidade. Sob este ponto de vista, a Tensão alta e a baixa Estabilidade Emocional relatadas podem ser apenas conseqüências de uma condição de maior ameaça percebida resultante da maior suscetibilidade ao mundo externo; que torne atraente a busca do conhecimento dos signos para previsão e controle. Pode ser então que as idéias dos signos sejam atraentes, quanto mais ansiosa a pessoa estiver em relação às suas interações sociais. A permanência das crenças em signos em nossos dias é 
compreensível: ajuda a enfrentar ameaças sociais, ajuda a compreender um mundo que parece caótico.

Uma fundamentação teórica mais abrangente para explicar a força atrativa das idéias dos signos advém da teoria do Meme, proposta por Richard Dawkins, que sem deixar de ser psicológica embasa a mente humana na evolução da espécie, por relacionar pelo conceito de informação o cultural e o biológico humano:

"Precisamos de um nome para o novo replicador, um substantivo que transmita a idéia de uma unidade de transmissão cultural, ou uma unidade de imitação. "Mimeme" provém de uma raiz grega adequada, mas quero um monossílabo que soe um pouco como "gene". Espero que meus amigos helenistas me perdoem se eu abreviar mimeme para meme. Se servir como consolo, pode-se, alternativamente, pensar que a palavra está relacionada à "memória", ou à palavra francesa même." (DAWKINS (1976), 2001, p. 214)

Memes seriam os blocos básicos de nossas mentes e da cultura, e Dawkins, sendo etólogo, procurou através deste conceito estender a teoria de Darwin - da evolução das espécies através da seleção natural - para a cultura humana. Memes podem ser considerados como constituintes das idéias, e existem e funcionam independentemente das crenças ou da vontade das pessoas. Assim os memes são reproduzidos culturalmente, não porque são bons ou ruins, mas porque têm "grande atratividade psicológica" (DAWKINS (1976), 2001, p. 215). “Memes como melodias, idéias e histórias disseminam-se de cérebro para cérebro e às vezes sofrem mutação na transmissão" (PINKER, 1991, p. 224). Memes levam à reprodução cultural e à conseqüente conservação cultural, favorecendo indiretamente a sobrevivência da espécie, já que sem esta não podem perdurar. Assim como aos genes, Dawkins considerou que os indivíduos são meros portadores ou veículos 
dos memes, dado que o que está em jogo é a preservação deles mesmos, através da preservação da espécie homo sapiens. Tornam-se predisponentes de idéias, conceitos e comportamentos coerentes com estes.

Lembrando da história da astrologia, podemos avaliá-la sobre o ponto de vista de sua utilidade cultural, como já sintetizamos no início. Podemos considerá-la inicialmente como um saber que é fruto de uma reflexão cultural, acumulada e transmitida no decorrer da história, sobre os ciclos observados na natureza. Sabemos o quanto isto foi importante para as culturas agrícolas. Posteriormente, com o crescente processo de observação e matematização, acompanhada do aumento da abrangência de suas aplicações, tornou-se um conhecimento religioso, explicando e prevendo as relações entre o céu e a terra. Passou a ser usada também para explicar as diferenças de almas e destinos, tanto em função dos deuses planetários como dos signos. Com isto as pessoas tornam-se explicáveis e previsíveis através destas representações, tanto para os outros quanto para si mesmas, sentem-se incluídas na ordem cósmica, acreditam que ali teriam sua imortalidade. Os signos, mais do que as divindades planetárias, ao mesmo tempo distinguem e incluem, dado o ciclo zodiacal e dado também que abrangem perto de um mês cada, enquanto a determinação planetária depende da hora do nascimento. Assim há uma variabilidade cíclica de relações dos mesmos elementos básicos, resultando em uma complexidade que pode ser analisada simbolicamente, relacionando com os acontecimentos da vida da pessoa. Daí favorece-se a compreensão do vivido e a previsibilidade.

Algo muito útil para as relações humanas, ainda mais devido à crescente complexidade e caoticidade da vida social (JUNG, 1983). Podemos dizer que a "astrologia natal" fornece um atraente mapa cognitivo. 
Sob este ponto de vista, o zodíaco, suas divindades planetárias e seus signos astrológicos são memes, ou pelo menos são compostos de memes. Isto se demonstra pelo fato de que a grande maioria de nossa amostra, 94,22\% (555/589) sabe dizer qual é seu signo, ainda que $64,69 \%$ foram classificados como não conhecedores das características de seus signos. Muitos dentre estes chegaram a responder com pelo menos uma característica correta de seu signo solar. Parece haver grande atratividade psicológica na idéia dos signos, que correspondem também a uma "psicologia popular" da personalidade usada por muitas pessoas para a compreensão de si e dos outros (ROOIJ, 1999).

Assim podem ser mais bem compreendidos os números significativos de Sachs (KNIGHT, LOMAS, 2004, p. 437-445) quanto às diferenças entre os signos. Resultados quanto a casamentos e divórcios podem ser casos de profecias auto-realizadoras (EDEN, KINNAR, 1991). Alguns resultados podem ter sido frutos comportamentais da autoatribuição de origem astrológica. Outros podem ser conseqüências de variações sazonais (ASCHOFF, 1990). Outros, ainda, podem resultar da interação entre os dois últimos fatores.

Pode ser então as pessoas se coloquem dentro do zodíaco, mesmo sem ser dar conta disso, mesmo sendo consideradas como não conhecedoras da astrologia. Pode ser que o poder das imagens zodiacais, uma vez tomado o contato com elas, seja suficiente para compor parte do autoconceito, mesmo que por um processo inconsciente (JUNG, 1968). 


\subsection{CONSIDERAÇÕES E RECOMENDAÇÕS FINAIS}

Podemos perceber que a avaliação da Ansiedade, além da Extroversão, deu uma figura mais ampla e mais complexa, mas ao mesmo tempo mais compreensível da variação astrológica das personalidades. Não há apenas a variação devido à auto-atribuição, que foi capturada na variação da Extroversão para os conhecedores, mas um fator adicional que apareceu mesmo entre os não conhecedores da astrologia. Isto pode ser visto tanto nos resultados de Rooij expressos aqui no Gráfico I para os não conhecedores, quanto em nossos resultados expressos no Gráfico IV, ainda que não com alta significância. Isto pode ser explicado exatamente pelo fato de que o que variou significativamente foi um fator que reúne a Ansiedade e a Extroversão: ser "externalizante" para os Quentes, e ser "internalizante", para os Frios. Aqui, parece que encontramos uma variável de origem astrológica que independe de um conhecimento sobre astrologia que vá além das imagens dos signos. Pode ser que o fato de o zodíaco ser inicialmente "...uma teoria projetada de caracteres" (JUNG, 1986) tenha levado, no decorrer dos séculos, a uma adequação entre as tendências fundamentais da personalidade e as imagens depuradas no zodíaco, de modo que há uma retroalimentação entre o comportamento auto-observado e as imagens sobre personalidade culturalmente disponíveis através do zodíaco. Se pudermos intercambiar aqui o conceito de projeção com o conceito de "esquema cognitivo prévio", sendo o zodíaco "lá' e o ser humano "aqui" unificados analogicamente pelas imagens do Elementos, então temos possibilidades maiores de compreensão do fenômeno. 
Podemos relembrar aqui o que escreveu um dos astrólogos mais influentes contemporaneamente:

\begin{abstract}
"A Astrologia se baseia numa dessas compreensões intuitivas identificando 'ordem' e 'os movimentos celestes dos astros'. A qualidade conceitual de 'ordem' estava latente no inconsciente. Era o resultado psicológico de uma ânsia de encontrar uma compensação para o aparente caos da existência cotidiana. Mais do que isto, o homem observou que havia uma regularidade notável nos movimentos do Sol, da Lua, das estrelas. Então o fator psicológico interno e a percepção externa apareceram de algum modo como idênticos. Um tornou-se símbolo da outra" (RUDHYAR, 1989, p. 69).
\end{abstract}

Assim podemos compreender que há uma sincronia simbólica entre diferenças de base natural para as personalidades, o que se entende por temperamento (MATTHEWS, DEARY, 1998), e as imagens do zodíaco, cumprindo ainda hoje a função de aplacar ansiedades, porém sociais. Como o mesmo autor, Dane Rudhyar, concluiu:

"O tipo e a classe de fenômenos da natureza que a astrologia correlaciona, interpreta e aos quais dá significado, em termos de um princípio de Ordem cósmica mudam era após era. A princípio eram fisiológicos e elementais. Agora devem ser essencialmente psicológicos e mentais. Mas o trabalho fundamental da astrologia continua o mesmo. É revelar a 'harmonia das esferas' em qualquer nível que a consciência humana esteja centrada. É carregar o símbolo de Ordem onde quer que o homem encontre caos. Em terminologia moderna, é a álgebra da vida" (1989, p. 40). 
Voltando aos resultados: é preciso lembrar que diferenças encontradas pela ANOVA são importantes por demonstrar-se não serem variações casuais, porém, em termos práticos, podem não ser significativas. As discrepâncias apontadas entre as médias dos grupos caem sempre dentro do limite do desvio-padrão de cada escala ${ }^{57}$, com diferenças entre $5 \%$ e $10 \%$ do total das escalas. Podemos entender então que tanto o efeito da auto-atribuição quanto o efeito do possível fator de base astrológica são em geral pequenos na formação da personalidade e das habilidades correlatas. Mas pode ser que tenhamos encontrado algo que vale a pena investigar com mais especificidade, em algumas direções aqui apontadas.

De início, a hipótese da suscetibilidade diferenciada segundo a escala Frio-Quente para a informação vinda de fora sobre a personalidade precisa ser reavaliada, através da investigação do efeito da informação de características neutras ou mesmo indesejáveis. Ainda que saibamos que o "Efeito Barnum" ocorra: o desejo da pessoa de aceitar descrições genéricas de personalidade que se afirme que ela possua (GLICK, GOTTESMAN, JOLTON, 1989). No entanto sabemos também por este mesmo experimento que pessoas anteriormente céticas em relação à astrologia passaram a aceitar essas descrições quando feita com termos com conotações positivas. Como vimos, a Despreocupação como característica componente da Extroversão tem maior desejabilidade social do que a preocupação ou a introversão, especialmente em nossa cultura "afetuosa". Assim, é plausível que fique mais fácil concordar com uma descrição de personalidade que inclua características desejáveis - sua favorabilidade - e logo incorporar isto no autoconceito.

\footnotetext{
${ }^{57}$ As diferenças são de aproximadamente 1 ponto para desvios-padrão em volta de 4 pontos, mas é esta proporção sistematicamente encontrada em todas as pesquisa citadas utilizando o EPI e suas versões (MAYO, WHITE, EYSENCK, 1977, p. 235)
} 
Também é recomendável que se realizem pesquisas mais específicas sobre as relações entre o autoconceito de origem astrológica, a auto-eficácia e a inteligência, com questionários específicos de auto-eficácia generalizada (GSE) para os conhecedores de astrologia (SHERER, MADUX et cols., 1982; SHERER, ADAMS, 1983; TIPTON, WORTHINGTON, 1984).

Do mesmo modo, seria necessário um estudo sobre a relação entre o locus de controle e o signo solar, utilizando-se de um questionário específico de locus de controle interno-externo (DELA COLETA, 1979). Parece que os resultados demonstram uma variação de origem astrológica independente da crença na astrologia, daí a hipótese da dimensão Frio - Quente. Pode ser que tenhamos também encontrado uma variação relativa à base biológica da Extroversão. Porém só com um estudo mais aprofundado com signo solar \& locus de controle \& conhecimento astrológico poderemos avaliar a existência e a validade desta dimensão.

Cabe ainda lembrar que apesar de que os resultados para a Extroversão não tenham sido conforme os previstos pela teoria astrológica, nem nos estudos anteriores nem neste, os resultados que indicaram diferenças entre os signos segundo a escala Frio-Quente podem ainda estar se referindo às bases biológicas da extroversão, ao menos como foi originariamente formulada por Jung. O que propusemos quanto aos Frios: "A pessoa se constrói predominantemente com interesse consciente no que vem de dentro para fora" pode muito bem ser o processo de aprendizagem da pessoa introvertida: "O interesse não se dirige para o objeto, mas dele se retrai e vai para o sujeito. Quem possui uma atitude introvertida pensa, sente e age de modo a deixar transparecer claramente que o motivador é o sujeito, enquanto o objeto recebe valor apenas secundário.” (JUNG, 1991, p. 430). Já o que propusemos quanto aos Quentes: “A pessoa se constrói predominantemente com interesse consciente no que vem de fora para dentro", coerentemente, pode ser o processo 
de aprendizagem da pessoa extrovertida: “...para o extrovertido, as qualidades positivas de importância e valor recaem em primeiro lugar sobre o objeto que desempenha, então, em todos os processos psíquicos o papel preponderante, condicionador e orientador." (JUNG, 1991, p. 508). "Para o extrovertido, o objeto é a priori interessante e atrativo, assim como para o introvertido o é o sujeito, respectivamente a realidade psíquica." (JUNG, 1991, p. 508).

Como explicar então que entre os não conhecedores tenha havido um resultado em Extroversão inverso ao previsto pela teoria astrológica? Em nossa Dissertação havíamos suposto que "Há então uma estrutura 'epigenética' para a correlação entre a base biológica da extroversão e o autoconceito construído socialmente" (RODRIGUES, 1997). Pelos resultados atuais esta suposição ganha mais apoio, gerando uma nova hipótese: Entre os não conhecedores, aqueles de signos Quentes, sendo por alguma razão mais introvertidos em média que os de signos Frios, pagam por isto o tributo de se tornarem mais ansiosos do que estes, dado que seriam por natureza tendentes à extroversão. Não terem utilizado a informação sobre seus signos para comporem o autoconceito pode ter feito com que algo ficasse faltando no desenvolvimento de suas personalidades, e isto acaba expressando-se na Ansiedade. Sabemos por Jung que, ao menos no tocante à Extroversão, há uma base biológica que já se expressa nos primeiros anos de vida. Jung supunha fundamentos fisiológicos para a extroversão ou a introversão: "Em hipótese alguma desejo subestimar a incontestável importância das influências parentais, mas nossa experiência nos obriga a procurar o fator decisivo na disposição da criança", para a definição do predomínio da extroversão ou da introversão (JUNG (1921), 1991, p. 318). As pesquisas de Eysenck (1973) demonstraram que há uma diferença de base neurológica no despertar cortical ${ }^{58} \mathrm{em}$

\footnotetext{
58 "Cortical arousal": “... introverts are more easily aroused, and tend to show higher levels of cortical arousal" (MATTHEWS, DEARY, 1998, p. 126), .
} 
função dos estímulos, mais baixo em geral para os extrovertidos. Não é que não seja possível a inversão do tipo, porém:

“Quando ocorre uma falsificação do tipo, devido a influências externas, o indivíduo se torna, na maioria dos casos, neurótico e a cura só é possível restabelecendo-se a atitude que naturalmente corresponderia ao indivíduo" (JUNG (1921), 1991, p. 318). Pode ter havido isto entre os Quentes e não conhecedores, como também entre os Frios e conhecedores, que tiveram os escores médios mais altos em Ansiedade. Mantêm-se a hipótese de que provavelmente a disposição natural corresponde a um ritmo biológico anual (WENDT, 1978), sincronizado com a alternância Frio-Quente do zodíaco.

Mas pode também ser que os testes utilizados - tanto o EPI e seus derivados, quanto o 16 PF - partam de conceitos de Extroversão que não tenham total superposição com o conceito proposto por Jung em 1921. Sob este ponto de vista foi uma falha do estudo ter usado exclusivamente o 16 PF. Seria interessante então uma replicação (por constructo) utilizando-se de um teste de personalidade estritamente baseado na teoria junguiana, como o QUATI, de Zacharias (2000). Poderíamos avaliar também assim uma teoria de tipos, que talvez encontre melhor concordância com as classificações astrológicas.

Com isto voltaríamos a abordar a questão inicial sobre signo solar e Extroversão, o motivo desta Tese; mas encerramos aqui considerando este trabalho como uma etapa desta linha de pesquisa. 


\section{ANEXO I: DESCRIÇÕES DOS SIGNOS POR “TRAÇOS”}

(PARKER, D., PARKER, J.: O Grande Livro da Astrologia. Círculo do Livro, São Paulo, 1982, p. 106129.)

\begin{tabular}{|c|c|c|}
\hline SIGNO & TRAÇOS POSITIVOS & TRAÇOS NEGATIVOS \\
\hline $\begin{array}{l}\text { ÁRIES } \\
\text { (CARNEIRO) }\end{array}$ & $\begin{array}{l}\text { Pioneiro, aventuroso, empreendedor, } \\
\text { corajoso, direto, enérgico, odeia } \\
\text { restrição, ama liberdade }\end{array}$ & $\begin{array}{l}\text { Egoísta, egocêntrico, sem sutileza, } \\
\text { impulsivo, belicoso, satírico, } \\
\text { irascível, impaciente }\end{array}$ \\
\hline TOURO & $\begin{array}{l}\text { Prático, digno de confiança, paciente, } \\
\text { hábil em negócios, resistente, senso } \\
\text { de valores, esteta, persistente, } \\
\text { determinado, afetivo, fidedigno }\end{array}$ & $\begin{array}{l}\text { Possessivo, preguiçoso, auto- } \\
\text { indulgente, chato, obstinado, } \\
\text { inflexível, convencional, ganancioso, } \\
\text { rancoroso, rotineiro }\end{array}$ \\
\hline GÊMEOS & $\begin{array}{l}\text { Adaptável, versátil, intelectual, } \\
\text { engenhoso, lógico, diligente, } \\
\text { espontâneo, jovial, comunicador }\end{array}$ & $\begin{array}{l}\text { Mutável, agitado, astucioso, } \\
\text { inquisitivo, inconsistente, duas caras, } \\
\text { nervoso, superficial, fofoqueiro }\end{array}$ \\
\hline $\begin{array}{l}\text { CÂNCER } \\
\text { (CARANGUEJO) }\end{array}$ & $\begin{array}{l}\text { Gentil, sensível, simpático, } \\
\text { imaginativo, maternal ou paternal, } \\
\text { solícito, protetor, cauteloso, } \\
\text { patriótico, tenaz, perspicaz, frugal }\end{array}$ & $\begin{array}{l}\text { Superemotivo, hiper-sensível, } \\
\text { mordaz, melindroso, mal-humorado, } \\
\text { mutável, rancoroso, instável, } \\
\text { facilmente lisonjeável, desmazelado }\end{array}$ \\
\hline LEÃO & $\begin{array}{l}\text { Magnânimo, generoso, criativo, } \\
\text { entusiasmado, organizador, } \\
\text { indulgente, expansivo, dramático }\end{array}$ & $\begin{array}{l}\text { Dogmático, brigão, pomposo, } \\
\text { esnobe, intolerante, fixo em opiniões, } \\
\text { condescendente, louco por poder, } \\
\text { dissimulado }\end{array}$ \\
\hline VIRGEM & $\begin{array}{l}\text { Discriminativo, analítico, meticuloso, } \\
\text { modesto, ordeiro, }\end{array}$ & $\begin{array}{l}\text { Minucioso, preocupado, hiper- } \\
\text { crítico, afetado, convencional, } \\
\text { enfadonho }\end{array}$ \\
\hline $\begin{array}{l}\text { LIBRA } \\
\text { (BALANÇA) }\end{array}$ & $\begin{array}{l}\text { Encantador, harmonioso, } \\
\text { despreocupado, romântico, } \\
\text { diplomata, idealista, refinado }\end{array}$ & $\begin{array}{l}\text { Indeciso, rancoroso, frívolo, mutável, } \\
\text { dado ao flerte, influenciável, crédulo, } \\
\text { oscilante entre extremos }\end{array}$ \\
\hline ESCORPIÃO & $\begin{array}{l}\text { Intenso emocional e } \\
\text { sentimentalmente, sentido de } \\
\text { finalidade, imaginativo, sutil, } \\
\text { persistente, determinado }\end{array}$ & $\begin{array}{l}\text { Ciumento, rancoroso, teimoso, } \\
\text { obstinado, intratável, reticente, } \\
\text { desconfiado }\end{array}$ \\
\hline SAGITÁRIO & $\begin{array}{l}\text { Jovial, otimista, versátil, mente } \\
\text { aberta, adaptável, filosófico, amante } \\
\text { da liberdade, sincero, franco, } \\
\text { fidedigno, escrupuloso }\end{array}$ & $\begin{array}{l}\text { Exagerado, extremista, sem tato, } \\
\text { inquieto, negligente, cegamente } \\
\text { otimista, turbulento, irresponsável, } \\
\text { caprichoso }\end{array}$ \\
\hline CAPRICÓRNIO & $\begin{array}{l}\text { Confiável, determinado, ambicioso, } \\
\text { cuidadoso, prudente, com senso de } \\
\text { humor, disciplinado, paciente, } \\
\text { perseverante }\end{array}$ & $\begin{array}{l}\text { Aparência rígida, superexigente, } \\
\text { pessimista, convencional, } \\
\text { mesquinho, avarento, desmancha- } \\
\text { prazeres }\end{array}$ \\
\hline AQUÁRIO & $\begin{array}{l}\text { Humanitário, independente, cordial, } \\
\text { prestativo, progressista, original, } \\
\text { inventivo, reformista, fiel, leal, } \\
\text { idealista, inclinações intelectuais }\end{array}$ & $\begin{array}{l}\text { Imprevisível, excêntrico, rebelde, } \\
\text { obstinado, sem tato, fixo nas suas } \\
\text { opiniões, caprichoso, } \\
\text { anticonvencional }\end{array}$ \\
\hline PEIXES & $\begin{array}{l}\text { Humilde, compassivo, simpático, } \\
\text { emotivo, desprendido, sensível, } \\
\text { adaptável, impressionável, gentil, } \\
\text { intuitivo, receptivo }\end{array}$ & $\begin{array}{l}\text { Dúbio, negligente, reticente, confuso, } \\
\text { pouco prático, fraca vontade, } \\
\text { indeciso }\end{array}$ \\
\hline
\end{tabular}




\section{ANEXO II: CONSENTIMENTO}

\section{CONSENTIMENTO PARA PARTICIPAR DA PESQUISA}

A- Identificação e Proposta

Paulo Roberto Grangeiro Rodrigues, da Pós-Graduação do Instituto de Psicologia da USP, está conduzindo este estudo sobre astrologia e personalidade, com o intuito de estabelecer um conhecimento científico sobre as relações entre a personalidade e o desempenho.

\section{B- Convite e Recusa}

Eu estou sendo convidado(a) a participar deste estudo, porque estou no grupo dos alunos da universidade onde leciona o Prof. Paulo Grangeiro, que têm psicologia ou matérias relacionadas entre seus estudos.

Eu sei que minha participação neste estudo é absolutamente voluntária. Eu tenho o direito de recusar a participar. Minha decisão em participar ou não desta pesquisa não terá influência sobre minha avaliação.

\section{C- Procedimentos}

Se eu concordar em participar deste estudo, ocorrerá o seguinte:

Responderei a um questionário de personalidade e outro sobre alguns conhecimentos, com o compromisso assumido pelo pesquisador de manter nomes e resultados confidenciais. Haverá possivelmente 1 aula de 2 horas aproximadamente.

D- Risco / Desconforto 
Não há nenhum efeito prejudicial antecipado em participar da pesquisa. Algumas perguntas são pessoais e delicadas. Se alguma questão me deixar constrangido(a) eu sou livre para me recusar a responder a qualquer momento.

Sigilo:

Meus dados serão guardados e usados o mais confidencialmente possível. Nenhuma identidade pessoal será usada em qualquer relato ou publicação que possam resultar do estudo. Nenhum nome será associado ao(s) questionário(s) ou entrevistas. Os testes e os questionários ficarão guardados em arquivo trancado somente acessível por este pesquisador. Deste modo nenhuma informação dada poderá ser acessada por qualquer pessoa que me conheça ou que tenha algum poder sobre minha situação.

\section{E- Benefícios}

Receberei, se desejar, a correção do teste, e poderei pedir esclarecimentos ao pesquisador sobre ele.

F- Questão

Se eu tiver alguma questão ou comentário sobre a participação neste estudo, eu posso falar com o(a) Professor Paulo Grangeiro, na minha Universidade.

G- Consentimento

Eu fui esclarecido por Paulo Grangeiro sobre o estudo e foi dada uma cópia deste consentimento para mim. Eu entendi o que li e tive minhas perguntas respondidas. A participação neste estudo é voluntária. Eu sou livre para recusar estar no estudo a qualquer momento. Minha decisão não irá afetar meus direitos ou minha situação na instituição.

Data: 
ANEXO III: FATORES DE PERSONALIDADE NO 16 PF

(baseado em ANDRADE, ALVES, 1993; MARAIST, RUSSELL, 2002)

\begin{tabular}{|c|c|c|c|}
\hline \multicolumn{2}{|c|}{ FATOR } & \multirow{2}{*}{$\begin{array}{l}\text { VALORES } \\
\text { BAIXOS }\end{array}$} & \multirow{2}{*}{$\begin{array}{l}\text { VALORES } \\
\text { ALTOS }\end{array}$} \\
\hline PORTUGUÊS & INGLÊS & & \\
\hline EXPANSIVIDADE & WARMTH & $\begin{array}{l}\text { reservado, } \\
\text { indiferente, } \\
\text { arredio, frio, crítico }\end{array}$ & $\begin{array}{l}\text { expansivo, afetuoso, } \\
\text { afável, } \\
\text { condescendente, } \\
\text { gentil }\end{array}$ \\
\hline INTELIGÊNCIA & $\begin{array}{l}\text { INTELLIGENCE / } \\
\text { REASONING }\end{array}$ & $\begin{array}{l}\text { menos inteligente, } \\
\text { pensamento } \\
\text { concreto }\end{array}$ & $\begin{array}{l}\text { mais inteligente, } \\
\text { pensamento abstrato }\end{array}$ \\
\hline $\begin{array}{l}\text { ESTABILIDADE } \\
\text { EMOCIONAL }\end{array}$ & $\begin{array}{l}\text { EMOTIONAL } \\
\text { STABILITY }\end{array}$ & $\begin{array}{l}\text { baixa tolerância a } \\
\text { frustrações, } \\
\text { inconstante, } \\
\text { impressionável, } \\
\text { irritável }\end{array}$ & $\begin{array}{l}\text { estável, calmo, com } \\
\text { ego forte, com visão } \\
\text { realista, } \\
\text { amadurecido }\end{array}$ \\
\hline AFIRMAÇÃO & DOMINANCE & $\begin{array}{l}\text { humilde, brando, } \\
\text { dócil, conformado, } \\
\text { submisso }\end{array}$ & $\begin{array}{l}\text { dominante, } \\
\text { autoritário, } \\
\text { agressivo, } \\
\text { obstinado, hostil }\end{array}$ \\
\hline DESPREOCUPAÇÃO & $\begin{array}{l}\text { IMPULSIVITY / } \\
\text { LIVELYNESS }\end{array}$ & $\begin{array}{l}\text { sóbrio, sério, } \\
\text { prudente, reticente, } \\
\text { introspectivo }\end{array}$ & $\begin{array}{l}\text { impulsivamente } \\
\text { animado, alegre, } \\
\text { entusiasta, jovial }\end{array}$ \\
\hline CONSCIENCIOSIDADE & $\begin{array}{l}\text { CONFORMITY / } \\
\text { RULE- } \\
\text { CONSCIOUSNESS }\end{array}$ & $\begin{array}{l}\text { evasivo, esquivo de } \\
\text { normas, instável } \\
\text { em propósitos, } \\
\text { imprevisível }\end{array}$ & $\begin{array}{l}\text { perseverante, preso a } \\
\text { normas, correto, } \\
\text { responsável }\end{array}$ \\
\hline DESENVOLTURA & SOCIAL BOLDNESS & $\begin{array}{l}\text { acanhado, } \\
\text { reprimido, receoso, } \\
\text { tímido, cauteloso }\end{array}$ & $\begin{array}{l}\text { sociável, } \\
\text { desembaraçado, } \\
\text { ousado, espontâneo, } \\
\text { afoito }\end{array}$ \\
\hline BRANDURA & SENSITIVITY & $\begin{array}{l}\text { masculino, rígido, } \\
\text { realista, prático, } \\
\text { cético }\end{array}$ & $\begin{array}{l}\text { feminino, terno, } \\
\text { sonhador, } \\
\text { dependente, sensível }\end{array}$ \\
\hline DESCONFIANÇA & $\begin{array}{l}\text { SUSPICIOUSNESS / } \\
\text { VIGILANCE }\end{array}$ & $\begin{array}{l}\text { confiante, } \\
\text { acomodado, sem } \\
\text { ciúmes, alegre }\end{array}$ & $\begin{array}{l}\text { desconfiado, } \\
\text { obstinado, ciumento, } \\
\text { suspeitoso }\end{array}$ \\
\hline IMAGINAÇÃO & $\begin{array}{l}\text { IMAGINATION / } \\
\text { ABSTRACTEDNESS }\end{array}$ & $\begin{array}{l}\text { prático, cuidadoso, } \\
\text { formalista, preciso }\end{array}$ & $\begin{array}{l}\text { criativo, desligado, } \\
\text { idealista, subjetivo }\end{array}$ \\
\hline REQUINTE & $\begin{array}{l}\text { SHREWDNESS / } \\
\text { PRIVATENESS }\end{array}$ & $\begin{array}{l}\text { simples, genuíno, } \\
\text { natural, } \\
\text { sentimental, } \\
\text { espontâneo }\end{array}$ & $\begin{array}{l}\text { requintado, } \\
\text { esmerado, polido, } \\
\text { intelectual sagaz }\end{array}$ \\
\hline APREENSÃO & $\begin{array}{l}\text { INSECURITY / } \\
\text { APPREHENSION }\end{array}$ & $\begin{array}{l}\text { plácido, seguro de } \\
\text { si, sereno, tranqüilo }\end{array}$ & $\begin{array}{l}\text { apreensivo, } \\
\text { perturbado, } \\
\text { deprimido, } \\
\text { preocupado }\end{array}$ \\
\hline
\end{tabular}




\begin{tabular}{|l|l|l|l|}
\hline EXPERIMENTAÇÃO & $\begin{array}{l}\text { RADICALISM / } \\
\text { OPENNESS TO } \\
\text { CHANGE }\end{array}$ & $\begin{array}{l}\text { conservador, } \\
\text { tradicional, } \\
\text { respeitador, } \\
\text { cauteloso, rotineiro }\end{array}$ & $\begin{array}{l}\text { liberal, radical, } \\
\text { crítico, analisador, } \\
\text { renovador }\end{array}$ \\
\hline AUTO-SUFICIÊNCIA & $\begin{array}{l}\text { SELF-SUFFICIENCY } \\
\text { / SELF-RELIANCE }\end{array}$ & $\begin{array}{l}\text { dependente do } \\
\text { grupo, fiel } \\
\text { seguidor, sectário }\end{array}$ & $\begin{array}{l}\text { independente, } \\
\text { decidido, basta-se a } \\
\text { si próprio }\end{array}$ \\
\hline AUTODISCIPLINA & $\begin{array}{l}\text { SELF-DISCIPLINE / } \\
\text { PERFECTIONISM }\end{array}$ & $\begin{array}{l}\text { impulsivo, rebelde, } \\
\text { indisciplinado }\end{array}$ & $\begin{array}{l}\text { controlado, } \\
\text { socialmente correto, } \\
\text { cuida da imagem }\end{array}$ \\
\hline TENSÃO & TENSION & $\begin{array}{l}\text { calmo, fleumático, } \\
\text { sereno, satisfeito, } \\
\text { distendido }\end{array}$ & $\begin{array}{l}\text { excitado, inquieto, } \\
\text { agitado, frustrado, } \\
\text { tenso }\end{array}$ \\
\hline
\end{tabular}




\section{REFERÊNCIAS BIBLIOGRÁFICAS}

1. AJZEN, I.: The theory of planned behavior. Organizational Behavior and Human Decision Processes, Vol. 50, p. 179-211, 1991.

2. ANDRADE, E. M.; ALVES, D. G.: Questionário de 16 Fatores de Personalidade. Manual Abreviado (01.05). CEPA, Rio de Janeiro, 1993.

3. ARROYO, S.: Astrologia, Psicologia e os Quatro Elementos. Pensamento, São Paulo, 1986.

4. ASCH, S.(1952): Psicologia Social. Companhia Editora Nacional, São Paulo, 1966.

5. ASCHOFF, J. : Biological Rhythms. Volume 4 de: Handbook of Behavioral Neurobiology. Plenum, New York, 1990.

6. BACHELARD, G. (1942): A Água e os Sonhos: Ensaio sobre a imaginação da matéria. Martins Fontes, São Paulo, 2002.

7. (1938): A Psicanálise do Fogo. Cultrix, São Paulo, 1990.

8. (1948): A Terra e os Devaneios da Vontade: Ensaio sobre a imaginação das forças. Martins Fontes, São Paulo, 2001.

9. (1948): A Terra e os Devaneios do Repouso: Ensaio sobre as imagens da intimidade. Martins Fontes, São Paulo, 2003.

10. (1943): O Ar e os Sonhos: Ensaio sobre a imaginação do movimento. Martins Fontes, São Paulo, 2001. 
11. BANDURA, A.: Self-efficacy: Toward a Unifying Theory of Behavioral Change. Psychological Review, Vol. 84 (2), p. 191-215, 1977.

12. BANDURA, A.: Self-efficacy Mechanism in Human Agency. American Psychologist, Vol. 37, p. 122-147, 1982.

13. BANDURA, A.: Social foundations of thought and action: a social cognitive theory. Prentice-Hall, Englewood Cliffs, NJ, 1986.

14. BARBAULT, A.: Del Psicoanalisis a la Astrología. Dédalo, Buenos Aires, 1975.

15. BEM, D.: Self-perception theory. In Berkowitz, L. (Ed.), Advances in experimental social psychology. Vol. 6, Academic Press, New York, 1972.

16. BERGER, P., LUCKMANN, T. : A construção social da realidade: tratado de sociologia do conhecimento. Vozes, Petrópolis, 1974.

17. BOYLE, G. J., STANKOV, L., CATTELL, R. B.: Measurement and Statistical Models in the Study of Personality and Intelligence. In: SAKLOFSKE, D. H., ZEIDNER, M. (Eds.): International Handbook of Personality and Intelligence. Plenum Press, New York, 1995.

18. BUENO, J. M. H., PRIMI. R.: Inteligência Emocional: Definição do Constructo e Instrumentos de Medida. In: SISTO, F. F., SBARDELINI, E. T. B., PRIMI, R. (Orgs.): Contextos e Questões da Avaliação Psicológica. Casa do Psicólogo, São Paulo, 2001.

19. CATTELL, R. B. : Abilities: Their structure, growth, and action. Houghton Mifflin, Boston, 1971.

20. CATTELL, R. B. : Personality and mood by questionnaire. Jossey-Bass Publishers, San Francisco 1973.

21. CATTELL, R. B., EBER, H. J., TATSUOKA, M. M. : Handbook for the sixteen personality factor questionnaire (16PF). Champaign, II.: Institute for Personality and Ability Testing, 1970.

22. COMREY, A. L., LAW, H., NOLLER, P, : Cattell, Comrey and Eysenck personality factors compared: more evidence for the five robust factors? Journal of Personality and Social Psychology, vol. 53(4), p. 775-782, 1987. 
23. CONN, S.R.: Comparison of the 16PF Fifth Edition and 16PF Form A (fourth edition). In: S.R. Conn \& M. L. Rieke (Eds.), The 16PF Fifth Edition technical manual. IPAT, Chapaign, Illinois, 1994.

24. CROWE, R. A. : Astrology and the scientific method. Psychological Reports, vol. 67(1), p. $163-191,1990$

25. CUMONT, F. ( 1912 ): Astrology and religion among the greeks and romans. New York, Dover, 1989.

26. DAWKINS, R. (1976): O Gene Egoísta. Itatiaia, Belo Horizonte, 2001.

27. DEAN, G. A., MATHER, A. C. M., and fifty-two others: Recent advances in natal astrology: a critical review 1900-1976. Para research, Whistlestop mall, Rockport, Massachussets 01966,USA. 1977.

28. DELA COLETA, J. A.: A escala de locus de controle interno-externo de Rotter: um estudo exploratório. Arquivos Brasileiros de Psicologia, Vol 31(4), p. 167-181, 1979.

29. DELA COLETA, J. A.: Atribuição de Causalidade: Teoria e Pesquisa. Fundação Getúlio Vargas, Rio de Janeiro, 1982.

30. DURAND, G.: A Imaginação Simbólica. Cultrix / EDUSP, São Paulo, 1988.

31. DURAND, G.: As Estruturas Antropológicas do Imaginário. Martins Fontes, São Paulo, 2001.

32. EDEN, D., \& KINNAR, J.: Modeling Galatea: Boosting Self-efficacy to increase volunteering. Journal of Applied Psychology, vol. 76, (6), p. 770-780, 1991.

33. EYSENCK, H. J. : Eysenck on extraversion. John Wiley \& Sons, New York, 1973.

34. EYSENCK, H. J., NIAS, D. K. B.: Astrology: science or superstition? Penguin Books, London, 1982.

35. FOURIE, D. P. : Self- attribution theory and the sun-sign. Journal of Social Psychology, vol. 122, p. 121-126, 1984.

36. FOURIE, D. P. : Geophysical variables and behavior: xxiv. Seasonal factors in extraversion. Psychologycal Reports, vol. 56, p. 3-8, 1985. 
37. GAUQUELIN, M.: The truth about astrology. Basil Blackwell, London, 1983.

38. GLICK, P., GOTTESMAN, D., JOLTON, J. : The fault is not in the stars: suscetibility of skeptics and believers in astrology to the Barnun effect. Personality \& Social Psychology Bulletin, vol. 15(4), p. 572-583, 1989.

39. GOLDBERG, L. R.: The development of markers for the big-five factor structure. Psychological Assessment, vol. 4(1), p. 26-42, 1992.

40. GRIGORENKO, E. L., STERNBERG, R. J.: Thinking Styles. In: SAKLOFSKE, D. H., ZEIDNER, M. (Eds.): International Handbook of Personality and Intelligence. Plenum Press, New York, 1995.

41. HAMILTON, M. M.: Incorporation of astrology-based personality information into long-term self-concept. Journal of Social Behavior and Personality. vol. 10, p. 707-718, 1995.

42. HAMILTON, M. M.: Who believes in astrology ? Effect of astrologically derived personality descriptions on acceptance of astrology. Personality \& Individual Differences. vol. 31(6), p. 895-902, 2001.

43. HEIDER, F.: Psicologia das Relações Interpessoais. Pioneira / EDUSP, São Paulo, 1970.

44. HUNTINGTON, E. : Season of Birth: its relation to human abilities. Wiley, New York, 1938.

45. JACKSON, MACD. P. : Extraversion, neuroticism, and date of birth: a southern hemisphere study. The Journal of Psychology, vol. 101, p. 197-198, 1979.

46. JACKSON. M. \& FIEBERT, M. S. : Introversion - extraversion and astrology. Journal of Psychology, vol. 105, p. 155-156, 1980.

47. JACQUES, E. : Os sistemas sociais como defesa contra a ansiedade persecutória e depressiva. In Temas de Psicanálise aplicada. Zahar editores, Rio de Janeiro, 1969.

48. JUNG, C. G.: A natureza da psique . Vozes, Petrópolis, 1986.

49. : Psicologia e alquimia. Vozes, Petrópolis, 1991. 
50. : Comentário europeu. In Wilhelm, R.: O segredo da flor de ouro. Vozes, Petrópolis, 1983.

51. (1952): Sincronicidade. Vozes, Petrópolis, 1985.

52. : The archetypes and the collective unconscious. C.W., vol. 9 - I. Routledge \& Kegan Paul, Londres, 1968.

53. (1921): Tipos Psicológicos. Vozes, Petrópolis, 1991.

54. KANEKAR, S., MUKERJEE, S. : Intelligence, extraversion, and neuroticism in relation to season of birth. Journal of Social Psychology, vol. 86, p. 309-310, 1972.

55. KELLY, I. W., DEAN, G. A., SAKLOFSKE, D. H.: Astrology: A Critical Review. In: GRIM, P. : Philosophy of Science and the Occult, p. 51-81. SUNY, Albany, N. Y., 1990.

56. KELLY, I. W.: Why astrology doesn't work. Psychological Reports. vol. 82, p. 527-546, 1998.

57. KLINE, P., BARRETT, P. : The factors in personality questionnaires among normal subjects. Advances in Behavioral Research and Therapy, vol. 5, p. 141-202, 1983.

58. KNIGHT, C., LOMAS, R.: The Book of Hiram: Freemasonry, Venus and the secret key to the life of Jesus. Arrow, London, 2004.

59. KOYRÉ, A. : Do mundo fechado ao universo infinito. Forense-Universitária/ Edusp, São Paulo, 1979.

60. KRUG, S. E. , JOHNS, E. F. : A large scale cross-validation of second order personality structure defined by the 16PF. Psychological Reports, vol. 59, p. 683-693, 1986.

61. KUHN, T. : The structure of the scientific revolutions. Phoenix Books, Chicago, 1962.

62. LLOYD, G. E. R. : O tempo no pensamento grego. In As culturas e o tempo. Edusp Vozes, 1982.

63. LOCKE, E. A., FREDERICK, E., LEE, C., BOBKO, P.: Effect of Self-efficacy, goals, and task strategies on task performance. Journal of Applied Psychology, vol. 69(2), p. 241251, 1984. 
64. LYKKEN, D. T. : Statistical significance in psychological research. Psychological Bulletin, vol . 70, p. 151-159, 1968.

65. MARAIST, C. C., RUSSELL, M. T.: 16PF Fifth Edition Norm Supplement, Release 2002. IPAT, Champaign, Illinois, 2002.

66. MARSHALL, P.: World Astrology: The astrologer's quest to undestand the human character. Macmillan, London, 2004.

67. MARTINDALE, A., MARTINDALE, C.: Metaphorical Equivalence of Elements and Temperaments: Empirical Studies of Bachelard's Theory of Imagination. Journal of Personality and Social Psychology, vol. 55(5), p. 836-848, 1988.

68. MATTHEWS, G.: The factor structure of the 16PF: Twelve primary factors and three secondary factors. Personality and Individual Differences, vol 10 (9), p. 931-940, 1989.

69. MATTHEWS, G., DEARY, I. J.: Personality Traits. Cambridge University Press, Cambridge, 1998.

70. MAYO, J., WHITE, O., EYSENCK, H. J. : An empirical study of the relation between astrological factors and personality. Journal of Social Psychology, vol. 105, p. 229-236, 1978.

71. MOORE, T.: The Planets Within: The Astrological Psychology of Marsilio Ficino. Lindisfarne Press, Hudson, N.Y., 1990.

72. MOURÃO, R. R. F.: Atlas Celeste. Vozes, Petrópolis, 1986.

73. MOURÃO, R. R. F.: Uranografia: Descrição do Céu. Francisco Alves, Rio de Janeiro, 1989.

74. MURGel, C. B., PERISSINOTTO, N.: Planisfério Celeste Rotativo (HS. 23.27) FUNBEC, São Paulo, 1988.

75. NAGELSCHIMIDT, A. M. P. C.: Mandala de Palavras. Vetor, São Paulo, 1996.

76. NISBETT, R. E., VALINS, S.: Perceiving the Causes of One's Own Behavior. In: Jones, E. E., et alii: Attribution: Perceiving the causes of behavior. General Learning Press, Morristown, New Jersey, 1972. 
77. PARKER, D., PARKER, J.: O Grande Livro da Astrologia. Círculo do Livro, São Paulo, 1982.

78. PAWLIK, K., BUSE, L.: Selbst Attribuierung als differentiell-psychologische Moderatorvariabele: Nachprüfung und Erklärung von Eysencks Astrologie Persönlich-keitsKorrelationen. [Self-attribution as a differential psychological moderator variable: check and explanations of Eysenck's Astrology-Personality-Correlations.] Zeitschrift für Sozialpsychologie, vol 10, p. 54-69, 1979.

79. PINKER, S.: Como a Mente Funciona. Companhia das Letras, São Paulo, 1991.

80. PTOLOMEU, C. (170 d.C.): Tetrabiblos. texto on-line em www.geocities.com / astrologysources / classicalgreece / tetrabiblos/, em 25/03/2003.

81. RODRIGUES, A.: Psicologia Social. Vozes, Petrópolis, 1996.

82. RODRIGUES, P. R. G.: Astrologia, Meio-Ambiente e Personalidade: Um estudo empírico. São Paulo, 1997. 144 p. Dissertação (Mestrado). Instituto de Psicologia da USP.

83. ROOIJ, J. J. F. V., BRAK, M. A., COMMANDEUR, J. J. F. : Introversion-extraversion and sun sign. Journal of Psychology, vol. 122(3), p. 275-278, 1988.

84. ROOIJ, J. J. F. V. : Introversion- extraversion: astrology versus psychology. Personality and Individual Differences, vol. 16(6), p. 985-988, 1994.

85. ROOIJ, J. J. F. V. : Self-concept in terms of astrological sun-sign traits. Psychological Reports, vol. 84, p. 541-546, 1999.

86. RUDHYAR, D. : A astrologia da personalidade. Pensamento, São Paulo, 1989.

87. : A prática da astrologia. Pensamento, São Paulo, 1985a.

88. Ritmo do zodíaco: o pulsar da vida. Alhambra, Rio de Janeiro, $1985 b$.

89. RUSSELL, J. \& WAGSTAFF, G. F. : Extraversion, neuroticism and time of birth. British Journal of Social Psychology, vol. 22, p. 27-31, 1983.

90. RUSSELL, M. T., KAROL, D. L.: 16PF, quinta edição: manual. CEPA, Rio de Janeiro, 1999. 
91. SAKLOFSKE, D. H., ZEIDNER, M.: (Eds.): International Handbook of Personality and Intelligence. Plenum, New York, 1995.

92. SCHULTZ, D. P., SCHULTZ, S. E.: Teorias da Personalidade. Pioneira Thomson Learning, São Paulo, 2002.

93. SHAUGHNESSY, M. F. , NEELY, R. , MANZ, A. , NYSTUL, M. : Effects of birth order, sex, and astrological signs on personality. Psychological Reports, vol. 66(1), p. 272-274, 1990.

94. SHERER, M., ADAMS, C. H.: Construct validation of the Self-efficacy Scale. Psychological Reports, vol. 53, p. 899-902, 1983.

95. SHERER, M., MADUX, J. E., MERCADANTE, B., PRENTICE-DUNN, S., JACOBS, B., ROGERS, R. W.: The Self-Eficacy Scale: Construction and validation. Psychological Reports, vol. 51, p. 663-671, 1982.

96. SMITHERS, A. G., COOPER, H. J. : Personality and season of birth. Journal of Social Psychology, vol. 105, p. 237-241, 1978.

97. SOSIS, R. H. , STRICKLAND, B. R. , HALEY, W. E. : Perceived locus of control and beliefs about astrology. Journal of Social Psychology, vol. 110, p. 65-71, 1980.

98. STANKOV, L., BOYLE, G. J., CATTELL, R. B.: Models ans Paradigms in Personality and Intelligence Research. In: SAKLOFSKE, D. H., ZEIDNER, M. (Eds.): International Handbook of Personality and Intelligence. Plenum Press, New York, 1995.

99. STARTUP, M.: Belief in astrology: a system of maladjustment? Personality and Individual Differences, vol.4(3), p. 343-345, 1983.

100.STORMS, M. D., NISBETT, R. E.: Insomnia and the attribution process. Journal of Personality and Social Psychology, vol. 16 (2), p. 319-328, Oct. 1970.

101. SULLIVAN, E.: Saturno em trânsito. Siciliano, São Paulo, 1992.

102. TIPTON, R. M., WORTHINGTON, E. L., Jr.: The measurement of generalized Selfefficacy: A study of construct validity. Journal of Personality Assessment, vol. 48, p. 545-548, 1984. 
103. TYSON, G. A. : Astrology or season of birth: a "split- sphere" test. Journal of Psychology, vol. 95, p. 285-287, 1977.

104. TYSON, G. A.: Persons who consult astrologers: a profile. Personality and Individual Differences, vol. 3 (2), p. 119-126, 1982.

105. VENO, A. , PAMMENT, P. : Astrological factors and personality: a southern hemisphere replication. Journal of Psychology, vol. 101, p. 73-77, 1979.

106. VILHENA, L. R.: O Mundo da Astrologia: Estudo Antropológico. Jorge Zahar Editor, Rio de Janeiro, 1990.

107. WEINER, B., et alii.: Perceiving the Causes of Success and Failure. In: Jones, E. E., et alii: Attribution: Perceiving the causes of behavior. General Learning Press, Morristown, New Jersey, 1972.

108. WENDT, H. W. : Season of birth, introversion, and astrology: a chronobiological alternative. Journal of Social Psychology, vol. 105, p. 243-247, 1978.

109. WIGGINS, J. S. : A Psychological Taxonomy of Trait-Descriptive Terms: The Interpersonal Domain. Journal of Personality and Social Psychology, vol. 37, p. 395412, 1979.

110. WUNDER, E.: Self-attribution, sun-sign traits, and the alleged role of favourableness as a moderator variable: long-term effect or artefact? Personality and Individual Differences, Vol. 35 (8) , p. 1783-1789, 2003.

111. ZACHARIAS, J. J. M.: QUATI: Questionário de Avaliação Tipológica. Manual. Vetor, São Paulo, 2000. 